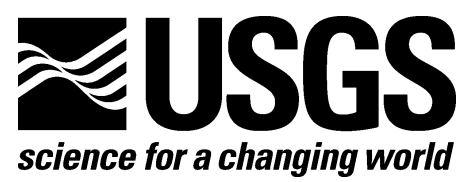

Prepared in cooperation with the Bureau of Land Management

\title{
Impact of Mine and Natural Sources of Mercury on Water, Sediment, and Biota in Harley Gulch Adjacent to the Abbott-Turkey Run Mine, Lake County, California
}

By James J. Rytuba, Roger L. Hothem, Brianne E. Brussee, and Daniel N. Goldstein

Open-File Report 2011-1265

U.S. Department of the Interior U.S. Geological Survey 


\section{U.S. Department of the Interior KEN SALAZAR, Secretary}

\section{U.S. Geological Survey Marcia K. McNutt, Director}

U.S. Geological Survey, Reston, Virginia: 2011

For product and ordering information: World Wide Web: http://www. usgs.gov/pubprod Telephone: 1-888-ASK-USGS

For more information on the USGS-the Federal source for science about the Earth,

its natural and living resources, natural hazards, and the environment:

World Wide Web: http://www.usgs.gov

Telephone: 1-888-ASK-USGS

Suggested citation:

Rytuba, J.J., Hothem, R.L., Brussee, B.E., and Goldstein, D.N., 2011, Impact of mine and natural sources of mercury on water, sediment, and biota in Harley Gulch adjacent to the Abbott-Turkey Run mine, Lake County, California: U.S. Geological Survey Open File Report 2011-1265, 105 p., available at http://pubs.usgs.gov/of/2011/1265/.

Any use of trade, product, or firm names is for descriptive purposes only and does not imply endorsement by the U.S. Government.

Although this report is in the public domain, permission must be secured from the individual copyright owners to reproduce any copyrighted material contained within this report. 


\section{Contents}

Introduction

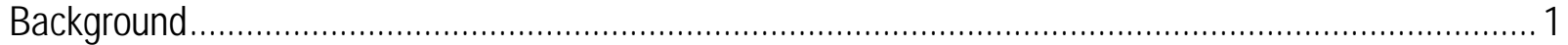

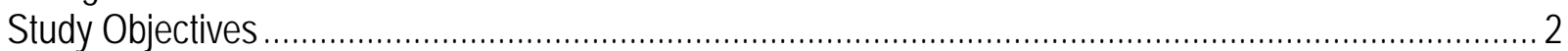

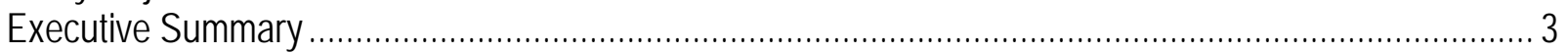

West Fork: Mine Area and Wetlands.............................................................................. 3

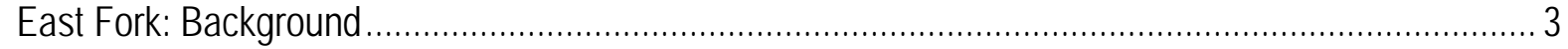

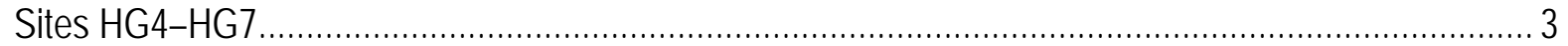

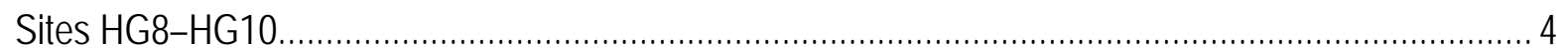

Mining History and Geology of the Abbott-Turkey Run Mine …..................................................... 5

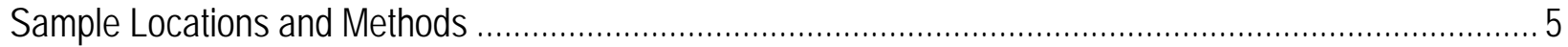

Sample Locations and Conditions: Water and Sediment …….................................................. 5

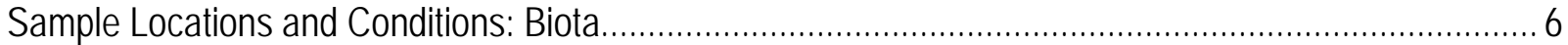

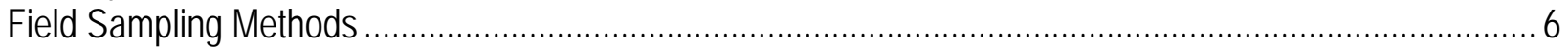

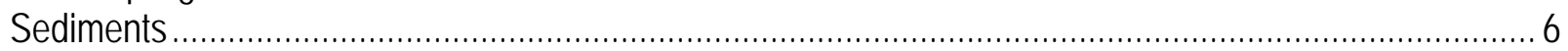

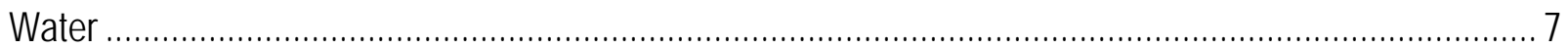

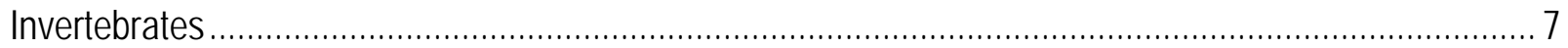

Frogs

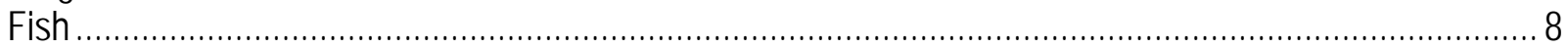

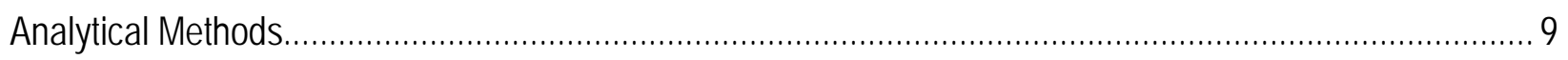

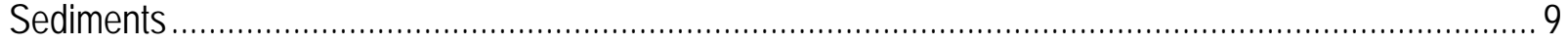

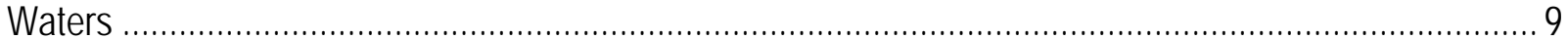

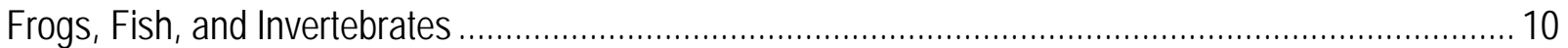

Dry-Weight Correction (percentage Solids) USEPA Method 160.3 (SOP BR-1501) ........................... 10

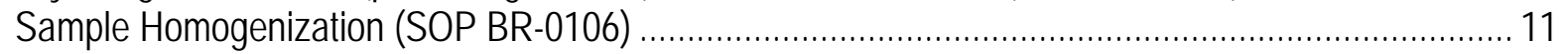

Total Mercury (SOP BR-0002) ………………………………......................................... 11

Monomethyl Mercury, USEPA Draft 1630 Modified (SOP BR-0011) .............................................. 11

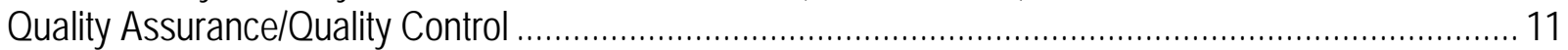

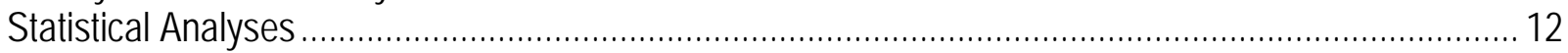

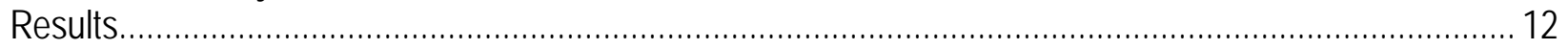

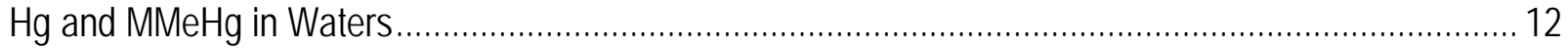

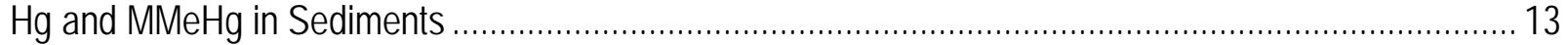

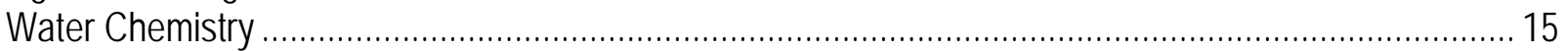

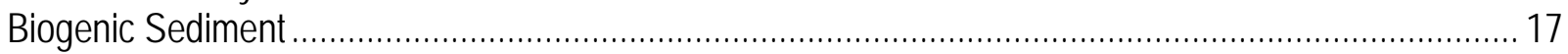

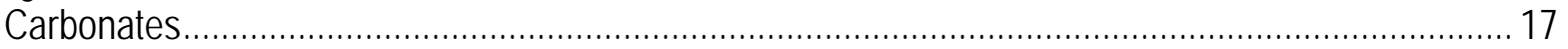

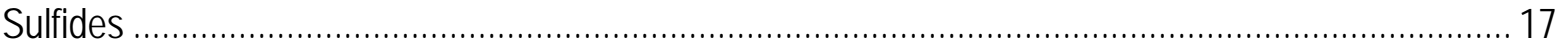

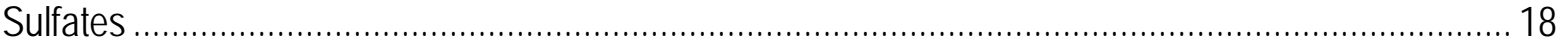

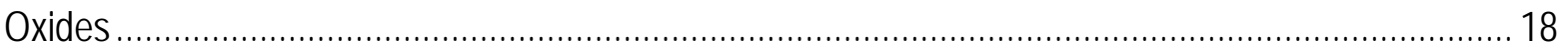

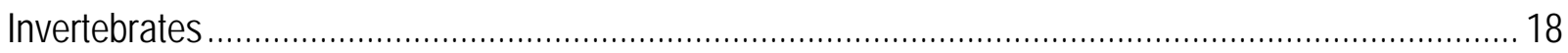

Frogs

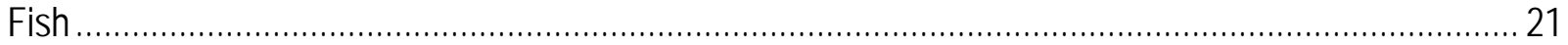

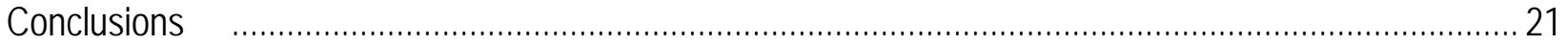

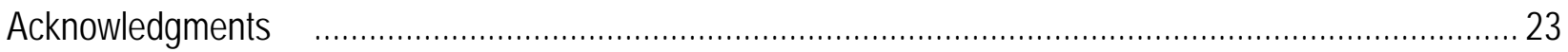

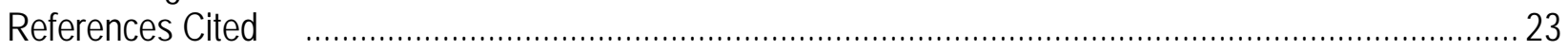




\section{Tables}

1. Sample locations and physical parameters from waters collected from Harley Gulch, Lake County, California.

2. Collection sites, for biological samples from Harley Gulch, Lake County, California, in 2007, 2008, 2010, and 2011.

3. Mercury and monomethylmercury concentrations in waters and sediment collected in Harley Gulch, Lake County, California.

4. Concentration of anions and selected cations in filtered water from Harley Gulch sample sites .

5. Mercury and associated major and minor elements in active stream channel, biogenic, and storm sediment, Harley Gulch

6. Unfiltered water, major and minor element concentrations from ICP-MS results (ICP-AES for major elements), Harley Gulch, Lake County, California.

7. Filtered water, major and minor element concentrations from ICP-MS (ICP-AES for major elements), Harley Gulch, Lake County, California.

8. Stable-isotope levels and calculated percent effluent in stream waters collected from Harley Gulch*, Lake County, California.

9. Total mercury $\left(\mathrm{Hg}_{\mathrm{T}}\right)$ and monomethyl mercury $(\mathrm{MMeHg})(\mu \mathrm{g} / \mathrm{g}$, wet wt) in individual composites of invertebrates collected at Harley Gulch in 2002, 2007, 2008, and 2010, and at a reference site, Bear River at Highway 20 (BR 20), during 1999-2002, Lake County, California.

10. Total mercury $\left(\mathrm{Hg}_{\mathrm{T}}\right)$ and monomethyl mercury $(\mathrm{MMeHg})(\mu \mathrm{g} / \mathrm{g}$, wet wt) in foothill yellow-legged frogs from Harley Gulch, Lake county, California, in 2007-2008.

11. Total mercury $\left(\mathrm{Hg}_{\mathrm{T}}\right)(\mu \mathrm{g} / \mathrm{g}$, wet $\mathrm{wt})$ in foothill yellow-legged frogs from Harley Gulch and reference sites, 1997-1998.

12. Total mercury $\left(\mathrm{Hg}_{\mathrm{T}}\right)$ and monomethyl mercury $(\mathrm{MMeHg})(\mu \mathrm{g} / \mathrm{g}$, wet wt) in California Roach (Hesperoleucus symmetricus) frogs from site HG8a, fish pond, collected on June 10, 2010, Harley Gulch, Lake County, California.

\section{Figures}

1. Location of sample sites in the Harley Gulch wetland and upper part of Harley Gulch downstream from the Abbott-Turkey Run mine, Lake County, California. Connate groundwater input occurs in the central part of the wetland at sample site HG1.5 and in the upper part of Harley Gulch between sample sites HG 4 and HG7.

2. Location of sample sites in the lower part of Harley Gulch, Lake County, California. Sample site HG10 is the most downstream water and sediment site sampled; see fig. 1 for locations of sites 2 and $2 a$.

3. Sample site HG1, Harley Gulch, Lake County, California, just downstream from Highway $20 \ldots \ldots . . . . . . . .56$

4. Sample site HG8-07, Harley Gulch Pond, Lake County, California, sampled only for biota on May 16, 2007.

5. Harley Gulch Wetlands, between Highway 20 and the confluence with East Fork Harley Gulch, Lake County, California.

6. Harley Gulch Wetlands sites, UDLW (left) and UDUP (right) sampled for biota only on June 10, 2010, Lake County, California.

7. Sample site HG3, East Fork of Harley Gulch, Lake County, California, upstream from the confluence with West Fork Harley Gulch.

8. West Fork of Harley Gulch, Lake County, California at sample site HG 2 downstream from wetland area. Sediment in creek bed is cemented by $\mathrm{CaCO}_{3}$ 
9. West Fork of Harley Gulch looking downstream from sample site HG2 toward sample site HG4 (location of geologist), Lake County, California. Creek bed is covered by efflorescent salts (white area) and sediment deposited from a high-flow event.....

10. Coarse pebble sand at site HG2, deposited during high-flow events in the winter of 2010 , has high $\mathrm{Hg}$ concentration $(136 \mu \mathrm{g} / \mathrm{g})$ because of erosion of tailings and $\mathrm{Hg}$-enriched soils from the AbbottTurkey Run mine, Lake County, California.

11. Pool at sample site HG4, Harley Gulch, Lake County, California with high $\mathrm{SO}_{4}-\mathrm{Cl}_{-}-\mathrm{CO}_{3}$ water derived from connate ground water. Water has high total mercury $\left(\mathrm{Hg}_{\mathrm{T}}\right)$ and filtered mercury $\left(\mathrm{Hg}_{\mathrm{F}}\right) \ldots 64$

12. Black reduced sediment at bottom of pool at site HG4, Harley Gulch, Lake County, California, consisting of biogenic and clastic sediment with high $\mathrm{Hg}$ concentration $(23.9 \mu \mathrm{g} / \mathrm{g}) \ldots \ldots \ldots \ldots \ldots \ldots \ldots \ldots . . . . . . . . . . . .65$

13. Sample site HG5 in the West Fork of Harley Gulch, Lake County, California. .......................................6 66

14. Sample site HG6 in the West Fork of Harley Gulch, Lake County, California. .................................... 67

15. Sample sites HG7 (left) and sample site HG8 (right) in the West Fork of Harley Gulch, Lake County, California.

16. Sample site HG8a, Fish Pond, Harley Gulch, Lake County, California, sampled only in 2010 (June 10 and June 17).

17. Sample sites HG9 and HG10 in the West Fork of Harley Gulch, Lake County, California. .70

18. Sample sites HG11, HG12, HG13, and HG14 (clockwise from top left), Lake County, California sampled for biota only on June 4, 2008, and June 17, 2010.

19. Locations of reference sites for studies at Harley Gulch, Lake County, California. [Foothill yellowlegged frog reference sites in 1997 were East Fork of Middle Creek (Middle), Spanish Creek (Spanish), and Bear Creek at Brim Road (Brim)] (Hothem and others, 2010)...

20. Logarithmic-scale plot showing concentrations of total mercury $\left(\mathrm{Hg}_{\mathrm{T}}\right)$ in water collected from sample sites in Harley Gulch, Lake County, California, moving downstream to the right on the Xaxis. Low-flow sampling events are shown with red bars; high-flow sampling events are shown with blue bars.

21. Logarithmic-scale plot showing concentrations of filtered mercury $\left(\mathrm{Hg}_{\mathrm{F}}\right)$ in water collected from sample sites in Harley Gulch, Lake County, California, moving downstream to the right on the Xaxis. Low-flow sampling events are shown with red bars; high-flow sampling events are shown with blue bars.

22. Logarithmic-scale plot showing concentrations of $\mathrm{MMeHg}$ in water collected from sample sites in Harley Gulch, Lake County, California, moving downstream to the right on the x-axis. Low-flow sampling events are shown with red bars; high-flow sampling events are shown with blue bars.

23. Logarithmic-scale plot showing concentrations of $\mathrm{Hg}$ and $\mathrm{MMeHg}$ in sediment collected from sample sites in Harley Gulch, Lake County, California, moving downstream to the right on the Xaxis. $\mathrm{Hg}$ concentrations are shown by red bars, and $\mathrm{MMeHg}$ concentrations with blue bars.

24. Plot showing concentration of $\mathrm{Hg}$ in sediments collected from Harley Gulch, Lake County, California. . Samples collected from the active stream channel of Harley Gulch are shown with blue bars; samples collected from the banks of Harley Gulch where storm sediment is deposited are shown with orange bars.

25. Harley Gulch, Lake County, California, downstream from sample site HG4 has abundant riparian vegetation because of input of connate groundwater in the segment of the creek between sample sites HG4 and HG7.

26. Plot of isotopic composition of waters in Harley Gulch, Lake County, California, which shows that the waters do not fall along the meteoric water line and are, thus, a mixture of connate water, thermal water, and meteoric water. 
27. Plot of chloride $(\mathrm{Cl})$ and $\delta^{18} \mathrm{O}$ of water in Harley Gulch, Lake County, California. The creek water becomes systematically heavier with higher $\mathrm{Cl}$ concentration downstream from site HG4, reaching a maximum in $\delta^{18} \mathrm{O}$ and $\mathrm{Cl}$ concentration at site HG7. The creek water then decreases in $\delta^{18} \mathrm{O}$ and $\mathrm{Cl}$ concentration owing to mixing with isotopically-light meteoric water.

28. Tan biogenic sediment at sample site HG8 forms in the upper part of Harley Gulch, Lake County, California, in the area between sample sites HG2A and HG9, where connate groundwater high in $\mathrm{SO}_{4}-\mathrm{Cl}-\mathrm{CO}_{3}$ enters the creek and dominates the water chemistry.

29. Tan biogenic sediment accumulating on creek bed at sample site HG7, Harley Gulch, Lake County, California, consists of living and recently expired diatoms with high concentrations of $\mathrm{Hg}[5.6 \mu \mathrm{g} / \mathrm{g}$ (ppm)], and MMeHg (0.5 ng/g)....

30. Black reduced sulfidic biogenic sediment below tan surface layer of biogenic sediment at sample site HG7, Harley Gulch, Lake County, California. The sediment consists of expired diatoms and FeS that gives the sediment a black color.

31. Biogenic sediment accumulates to a thickness of several $10 \mathrm{~s}$ of $\mathrm{cm}$ in Harley Gulch, Lake County, California. Above site HG4, during the dry season, biogenic sediment with high $\mathrm{Hg}$ concentration $[23.9 \mu \mathrm{g} / \mathrm{g}(\mathrm{ppm})]$ locally becomes dry and has the consistency of diatomite.

32. Biogenic sediment composed primarily of a variety of diatoms and diatom fragments and minor $\mathrm{CaCO}_{3}$ and clay minerals.

33. SEM (scanning electron microscopy) image of micron to submicron grains and aggregates of $\mathrm{HgS}$ in the biogenic sediment. EDAX spectrum confirms the presence of only $\mathrm{Hg}$ and sulfur $(\mathrm{S})$ in the bright particles in the SEM image.

34. SEM (scanning electron microscopy) image of micron to and aggregate of submicron grains of $\mathrm{HgS}$ in association with diatoms in the biogenic sediment. EDAX spectrum confirms the presence of only $\mathrm{Hg}$ and $\mathrm{S}$ in the high reflectivity aggregate of $\mathrm{HgS}$ in the SEM image.

35. SEM (scanning electron microscopy) image of aggregate of submicron grains of FeS in association with diatoms in the biogenic sediment. EDAX spectrum confirms the presence of only Fe and $S$ in the high reflectivity aggregate of FeS in the SEM image.

36. SEM (scanning electron microscopy) image of micron crystals and acicular grains of barite in association with diatoms in the biogenic sediment. EDAX spectrum confirms the presence of only $\mathrm{Ba}$ and $\mathrm{S}$ in the high reflectivity grains of barite.

37. SEM (scanning electron microscopy) image of epsomite crystals in biogenic sediment. EDAX spectrum confirms the presence of $\mathrm{Mg}$ and $\mathrm{S}$ in the crystals.

38. SEM (scanning electron microscopy) image of biogenic calcite fragment in biogenic sediment. EDAX spectrum confirms the presence of $\mathrm{Ca}$ and $\mathrm{C}$ in the crystals.

39. SEM (scanning electron microscopy) image of tungsten- (W) and titanium- (Ti) oxide phases in biogenic sediment. EDAX spectrum confirms the composition of the phases.

40. Monomethylmercury (MMeHg, $\mu \mathrm{g} / \mathrm{g}$, wet wt) in individual composite samples of predaceous diving beetles (Order Coleoptera, Family Dytiscidae) collected from Harley Gulch, Lake County, California, in2008, 2010, and 2011.

41. Monomethyl mercury (MMeHg, $\mu \mathrm{g} / \mathrm{g}$, wet wt) in composite samples of water striders (Order Hemiptera, Family Gerridae) collected from Harley Gulch, Lake County, California in 2007, 2008, 2010, and 2011.

42. Monomethyl mercury (MMeHg, $\mu \mathrm{g} / \mathrm{g}$, wet wt) in individual composite samples of dragonflies (Order Odonata, Families Libellulidae and Aeshnidae) collected from Harley Gulch, Lake County, California, in 2007, 2008, 2010, and 2011 
43. Monomethyl mercury (MMeHg, $\mu \mathrm{g} / \mathrm{g}$, wet wt) in individual composite samples of damselflies (Order Odonata, Families Coenagrionidae and Lestidae) collected from Harley Gulch, Lake County, California, in 2008, 2010, and 2011.

44. Monomethylmercury (MMeHg, $\mu \mathrm{g} / \mathrm{g}$, wet wt) in individual composite samples of larval water scavenger beetles (Order Coleoptera, Family Hydrophilidae) collected from Harley Gulch, Lake County, California, in 2008, 2010, and 2011.

45. Total mercury $\left(\mathrm{Hg}_{\mathrm{T}}, \mu \mathrm{g} / \mathrm{g}\right.$, wet wt) concentrations and percent monomethyl mercury (MMeHg) (black dots) in individual composite samples of invertebrates (larval Coenagrionidae, adult Dytiscidae, larval Hydrophilidae, and adult Gerridae) collected from a reference site (HG3) and sites in the Harley Gulch wetlands, Lake County, California, in 2010 (blue) and 2011 (green).

46. Comparison of percent monomethyl mercury in individual composite samples of water striders (Gerridae) and dragonflies (Libellulidae) collected from four sites in the Harley Gulch, Lake County, California, during 2007 (black), 2010 (gray), and 2011 (blue).

47. Geometric mean total $\mathrm{Hg}\left(\mathrm{Hg}_{\mathrm{T}}, \mu \mathrm{g} / \mathrm{g}\right.$, wet wt), with 95 percent confidence limits and sample sizes (n), in whole bodies of foothill yellow-legged frogs (FYLF) collected from East Fork Harley Gulch $(\mathrm{H} 3)$ and four sites $(\mathrm{H} \mathrm{4-7)}$ downstream of the confluence of East and West Forks Harley Gulch in May 2007 (table 3), from three reference sites during April-May 1997 (SPCR, Spanish Creek; EFMC, East Fork Middle Creek; BRIM, Bear Creek at Brim Road) (fig. 19), and from Harley Gulch in 1997-1998 (table 11). Harley Gulch included one FYLF from Turkey Run upstream of the West Fork of Harley Gulch in 1997 and one FYLF from the Abbott Mine Drain in 1998 (fig. 1). Means not sharing a common letter were different $(P<0.05)$ by Tukey pairwise multiple-comparison procedure.

48. Total mercury $\left(\mathrm{Hg}_{\mathrm{T}}\right)$ concentrations $(\mu \mathrm{g} / \mathrm{g}$, wet wt) in samples of foothill yellow-legged frogs collected from Harley Gulch, Lake County, California, in March-April 1997, March 1998, May 2007, and June 2008. Geometric means are presented for sites where $n>1$. Reference sites (SPCR, Spanish Creek; EFMC, East Fork Middle Creek; BRIM, Bear Creek at Brim Road) were sampled in April-May 1997 (fig. 19). Because only monomethyl mercury (MMeHg) was measured in frogs in 2008, $\mathrm{Hg}_{\mathrm{T}}$ was estimated for these frogs based on 50 percent MMeHg found in frogs analyzed for both MMeHg and $\mathrm{HG}_{\mathrm{T}}$ in 2007.

49. Monomethyl mercury (MMeHg) concentrations ( $\mu \mathrm{g} / \mathrm{g}$, wet wt) in foothill yellow-legged frogs collected from Harley Gulch, Lake County, California, in June 2008. N=2 for HG8; for all other sites, $\mathrm{N}=1$.

50. Transfer of $\mathrm{Hg}$ and $\mathrm{MMeHg}$ from the water column into the food web first occurs in phytoplankton. The bioaccumulation factor for both $\mathrm{Hg}$ and $\mathrm{MMeHg}$ is the highest during this transfer, but is still significant in the $\mathrm{Hg}$ trophic transfer between phytoplankton and zooplankton (step 2) and upward in the food web, such that fish can have very high $\mathrm{Hg}$ and $\mathrm{MMeHg}$ concentrations

51. The bioaccumulation factor between phytoplankton in the biogenic sediment in Harley Gulch, Lake County, California, in total $\mathrm{Hg}\left(\mathrm{Hg}_{\mathrm{T}}\right)$ (blue) and filtered $\mathrm{Hg}\left(\mathrm{Hg}_{\mathrm{F}}\right)$ (red) in water is very high; 37,700 in $\mathrm{Hg}_{\mathrm{T}}$ and 64,200 in $\mathrm{Hg}_{\mathrm{F}}$. The linear relationship demonstrates the $\mathrm{Hg}$ concentration in the biogenic sediment is a function of the $\mathrm{Hg}$ concentration in water.

52. Model for bioaccumulation of $\mathrm{Hg}$ and $\mathrm{MMeHg}$ in diatoms from the water column and subsequent release of $\mathrm{Hg}$ and $\mathrm{MMeHg}$ from the expired diatom that reacts with sulfide to form $\mathrm{HgS}$ and precipitation FeS from reaction of Fe in the pore fluids with sulfide. 


\section{Abbreviations, Definitions, and Datum Used}

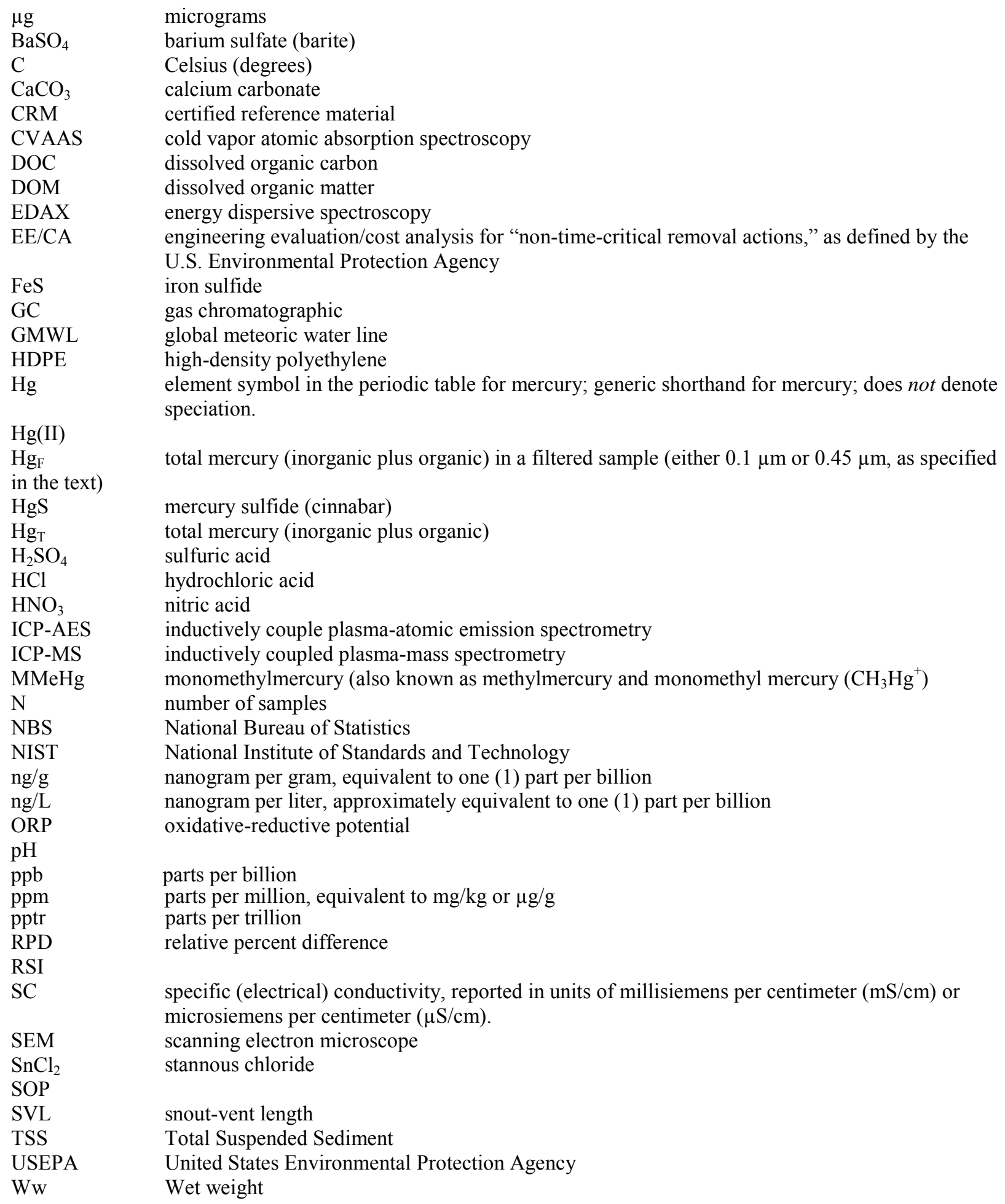




\section{Conversion Factors}

\begin{tabular}{|c|c|c|}
\hline Multiply & By & To obtain \\
\hline \multicolumn{3}{|c|}{ Length } \\
\hline inch (in.) & 2.54 & centimeter $(\mathrm{cm})$ \\
\hline inch (in.) & 25.4 & millimeter $(\mathrm{mm})$ \\
\hline foot (ft) & 0.3048 & meter $(\mathrm{m})$ \\
\hline mile (mi) & 1.609 & kilometer $(\mathrm{km})$ \\
\hline \multicolumn{3}{|c|}{ Area } \\
\hline acre & 4,047 & square meter $\left(\mathrm{m}^{2}\right)$ \\
\hline acre & 0.004047 & square kilometer $\left(\mathrm{km}^{2}\right)$ \\
\hline square mile $\left(\mathrm{mi}^{2}\right)$ & 259.0 & hectare (ha) \\
\hline square mile $\left(\mathrm{mi}^{2}\right)$ & 2.590 & square kilometer $\left(\mathrm{km}^{2}\right)$ \\
\hline \multicolumn{3}{|c|}{ Volume } \\
\hline cubic inch $\left(\right.$ in $\left.^{3}\right)$ & 0.01639 & cubic centimeter $\left(\mathrm{cm}^{3}\right)$ \\
\hline cubic foot $\left(\mathrm{ft}^{3}\right)$ & 28.32 & cubic decimeter $\left(\mathrm{dm}^{3}\right)$ \\
\hline cubic foot $\left(\mathrm{ft}^{3}\right)$ & 0.02832 & liter $(\mathrm{L})$ \\
\hline cubic yard $\left(\mathrm{yd}^{3}\right)$ & 0.7646 & cubic decimeter $\left(\mathrm{dm}^{3}\right)$ \\
\hline cubic mile $\left(\mathrm{mi}^{3}\right)$ & 4.168 & cubic meter $\left(\mathrm{m}^{3}\right)$ \\
\hline acre-foot (acre-ft) & 1,233 & cubic meter $\left(\mathrm{m}^{3}\right)$ \\
\hline acre-foot (acre-ft) & 0.001233 & cubic kilometer $\left(\mathrm{km}^{3}\right)$ \\
\hline \multicolumn{3}{|c|}{ Mass } \\
\hline ounce, avoirdupois (oz) & 28.35 & $\operatorname{gram}(\mathrm{g})$ \\
\hline pound, avoirdupois (lb) & 0.4536 & kilogram (kg) \\
\hline ton, short $(2,000 \mathrm{lb})$ & 0.9072 & megagram $(\mathrm{Mg})$ \\
\hline ton, long $(2,240 \mathrm{lb})$ & 1.016 & megagram $(\mathrm{Mg})$ \\
\hline ton per day (ton/d) & 0.9072 & metric ton per day \\
\hline ton per day (ton/d) & 0.9072 & megagram per day $(\mathrm{Mg} / \mathrm{d})$ \\
\hline $\begin{array}{l}\text { ton per day per square mile } \\
{\left[(\text { ton } / \mathrm{d}) / \mathrm{mi}^{2}\right]}\end{array}$ & 0.3503 & $\begin{array}{l}\text { megagram per day per square } \\
\text { kilometer }\left[(\mathrm{Mg} / \mathrm{d}) / \mathrm{km}^{2}\right]\end{array}$ \\
\hline ton per year (ton/yr) & 0.9072 & megagram per year $(\mathrm{Mg} / \mathrm{yr})$ \\
\hline ton per year (ton/yr) & 0.9072 & metric ton per year \\
\hline \multicolumn{3}{|c|}{$\begin{array}{l}\text { Temperature in degrees Celsius }\left({ }^{\circ} \mathrm{C}\right) \text { may be converted to degrees Fahrenheit }\left({ }^{\circ} \mathrm{F}\right) \text { as follows: } \\
{ }^{\circ} \mathrm{F}=\left(1.8 \times{ }^{\circ} \mathrm{C}\right)+32 \\
\text { Temperature in degrees Fahrenheit }\left({ }^{\circ} \mathrm{F}\right) \text { may be converted to degrees Celsius }\left({ }^{\circ} \mathrm{C}\right) \text { as follows: } \\
{ }^{\circ} \mathrm{C}=\left({ }^{\circ} \mathrm{F}-32\right) / 1.8 \\
\text { Horizontal coordinate information is referenced to the North American Datum of } 1983(\mathrm{NAD} 83) \text {. } \\
\text { Concentrations of chemical constituents are given in micrograms per gram }(\mu \mathrm{g} / \mathrm{g}) \text {. }\end{array}$} \\
\hline
\end{tabular}




\title{
Impact of Mine and Natural Sources of Mercury on Water, Sediment and Biota in Harley Gulch Adjacent to the Abbott-Turkey Run Mine, Lake County, California
}

\author{
By James J. Rytuba1 ${ }^{1}$ Roger L. Hothem², Brianna E. Brussee², \\ and Daniel N. Goldstein ${ }^{1}$
}

\section{Introduction}

\section{Background}

The Cache Creek watershed covers 2,950 $\mathrm{km}^{2}$ within the central part of the California Coast Ranges, an area with numerous geologic sources of mercury $(\mathrm{Hg})$. A long history of $\mathrm{Hg}$ mining has resulted in environmental $\mathrm{Hg}$ contamination (Rytuba, 2000). The major source of $\mathrm{Hg}$ exported from the watershed originates from historic $\mathrm{Hg}$ mining in the upper watershed (Foe and Croyle, 1998). Studies conducted by the California Regional Water Quality Control Board during 1996-1998 confirmed that Cache Creek was a major source of Hg to the Sacramento-San Joaquin River Delta and San Francisco Bay Estuary (Foe and Croyle, 1998).

Harley Gulch, a tributary to Cache Creek, located in Lake County, California, is listed as impaired by $\mathrm{Hg}$ contamination under citation of Section 303(d) of the Clean Water Act (Central Valley Regional Water Quality Control Board, 2003). The Harley Gulch tributary has been identified as a major source of $\mathrm{Hg}$ to Cache Creek (Foe and Bosworth, 2008). The primary source of $\mathrm{Hg}$ contamination in Harley Gulch has been the Abbott-Turkey Run Hg mine.

Natural sources of $\mathrm{Hg}$ also occur in the Cache Creek watershed, including thermal carbonate-chloride springs commonly associated with the $\mathrm{Hg}$ deposits, and cold carbonatechloride springs that discharge connate groundwater. The thermal springs have high concentrations of $\mathrm{Hg}$ and are actively depositing $\mathrm{Hg}$ and associated trace metals (DonnellyNolan and others, 1993). The cold carbonate-chloride springs and associated connate groundwater occur peripherally to the $\mathrm{Hg}$ deposits and have variable but often high concentrations of $\mathrm{Hg}$ and associated metals (Slowey and Rytuba, 2008).

Information on the concentrations of $\mathrm{Hg}$ in water, sediments (Foe and Croyle, 1998; Domagalski, 2001; Domagalski and others, 2004), invertebrates (Slotton and others, 1997, 2004), and fish (Slotton and others, 1995) from the Cache Creek watershed have helped define the sources and magnitude of $\mathrm{Hg}$ contamination in the watershed. Where fish are not commonly available to serve as bioindicators of $\mathrm{Hg}$ contamination, as in upper Harley Gulch, amphibians can be good surrogates because they occupy a similar trophic level, tend to bioaccumulate $\mathrm{Hg}$, and are sensitive to the effects of $\mathrm{Hg}$ (Cooke, 1981). In addition, amphibians have obligate aquatic larval stages, are often able to persist in aquatic systems unsuitable for fish, and are normally less mobile than fish, sometimes spending their entire life cycle in a single pond or

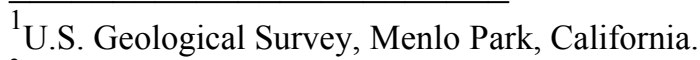

${ }^{2}$ U.S. Geological Survey, Dixon, California.
} 
reach of a stream. Prior to this study, information on $\mathrm{Hg}$ concentrations in amphibians in the Harley Gulch was not available.

The Central Valley Regional Water Quality Control Board established a Total Maximum Daily Load (TMDL) for monomethylmercury (MMeHg) in Harley Gulch, based on water, sediment, and biota data, collected by Ichikawa and Jakl (2004). Their data showed high concentrations of $\mathrm{Hg}$ in Harley Gulch downstream from the Abbott-Turkey Run mines and low to background concentrations in the East Fork of Harley Gulch where mines are not present. Ichikawa and Jakl also documented high levels of $\mathrm{Hg}$ in the Harley Gulch delta at the confluence with Cache Creek. The existing annual load to Harley Gulch was estimated to be $7-10 \mathrm{~kg} / \mathrm{year}$ of $\mathrm{Hg}$ and $1.0 \mathrm{~g} /$ year of $\mathrm{MMeHg}$, with an acceptable annual $\mathrm{MMeHg}$ load of $0.04 \mathrm{~g} / \mathrm{yr}$. The TMDL adopted for Harley Gulch is $0.09 \mathrm{ng} / \mathrm{L}(\mathrm{ppb}$ ) annual, median aqueous (unfiltered) $\mathrm{MMeHg}$, which is needed to attain the target of $0.05 \mathrm{mg} / \mathrm{kg}(\mathrm{ppm})$ wet weight $\mathrm{MMeHg}$ in trophic level 2 and 3 fish.

$\mathrm{Hg}$ was discovered in the Abbott-Turkey Run mine in 1862, and the mine was worked intermittently from the early 1870 s until 1971, when mining ceased. During this period, the mine produced more than 50,000 flasks of Hg. Much of Harley Gulch is Federal land managed by the U.S. Bureau of Land Management (USBLM). The USBLM requested that the U.S. Geological Survey (USGS) measure and characterize Hg and other geochemical constituents in sediment, water, and biota in Harley Gulch downstream from the Abbott-Turkey Run mine. This report responds to a request from the BLM in support of its Abandoned Mine Lands Program, funded by Congress under the authority of the Clean Water Act.

$\mathrm{Hg}$ and $\mathrm{MMeHg}$ contamination of water, sediment, and biota downstream from the mine led the Environmental Protection Agency (EPA) to undertake a cleanup of the Abbott-Turkey Run mines. Cleanup at the mine began on October 10, 2006, and was completed on September 6, 2007 at a total cost of $\$ 5$ million. Hg mine wastes that were judged to be leachable were removed from the mine to a waste site in Nevada. Mine wastes which were considered unleachable were capped with a 2-foot-thick layer of native soil at the mine site. Stabilization of mine wastes and slopes was engineered to withstand a 100-year flood event. Much of the abandoned mining equipment was removed, and the mine entries were filled and capped (Larson, 2007). Thermal water from the Turkey Run adit was diverted such that it did not flow over tailings, but continues to flow into the upper part of Harley Gulch.

\section{Study Objectives}

The objectives of this multi-year study were (1) to determine concentrations of $\mathrm{Hg}$ in water, sediment, and biota after cleanup of waste material had been completed and (2) to characterize transport of $\mathrm{Hg}$ in the watershed post-removal action. Sampling occurred in two phases: first, biota were sampled to determine the amount of overall $\mathrm{Hg}$ contamination present post-removal (as compared to reference sites and pre-removal sampling), and second, water, sediment, and biota were jointly sampled to determine more accurately the characteristics of the contamination. In 2007, Hg concentrations in foothill yellow-legged frogs (Rana boylii), and their potential invertebrate prey in Harley Gulch, was measured and compared to reference values (Hothem and others, 2010). In 2010-2011, Hg contamination in foothill yellow-legged frogs and invertebrates from sites sampled in 2007 were further quantified. Hg contamination upstream of those sites in the wetlands of Harley Gulch and downstream of the sites sampled in 2007 to the confluence of Harley Gulch with Cache Creek also was evaluated. In 2010 and 2011, water and sediment were sampled in Harley Gulch under both low- and high-flow 
conditions. Natural sources of $\mathrm{Hg}$ and $\mathrm{MMeHg}$ that previously were unrecognized were studied, and the results are presented in this report.

\section{Executive Summary}

Stable-isotope data indicate that there are three sources of water that affect the composition and $\mathrm{Hg}$ concentration of waters in Harley Gulch: (1) meteoric water that dominates water chemistry during the wet season; (2) thermal water effluent from the Turkey Run mine that affects the chemistry at sample site HG1; and (3) cold connate groundwater that dominates water chemistry during the dry season as it upwells and reaches the surface. The results from sampling executed for this study suggest four distinct areas in Harley Gulch: (1) the contaminated West Fork of Harley Gulch, consisting of the stream immediately downstream from the mine area and the wetlands upstream from Harley Gulch canyon (sample sites HG1-HG2, (2) the East Fork of Harley Gulch, where no mining has occurred (sample site HG3), (3) sample sites HG4-HG7, where a seasonal influx of saline groundwater alters stream chemistry, and (4) sample sites HG7-HG10, downstream in Harley Gulch towards the confluence with Cache Creek.

\section{West Fork: Mine Area and Wetlands}

The concentration of $\mathrm{Hg}$ in both storm sediment and active channel sediment was highest at sample site HG1, immediately downstream from the mine. The highest concentrations of total $\mathrm{Hg}\left(\mathrm{Hg}_{\mathrm{T}}\right)$ in water also occurred at site $\mathrm{HG}$, and they decreased systematically downstream from the mine. The high concentration of $\mathrm{Hg}_{\mathrm{T}}$ at site $\mathrm{HGl}$ reflects input of thermal-water effluent from the Turkey Run mine which comprises most of the flow at this site during the dry season. During the May 2011 low-flow sampling, $\mathrm{Hg}_{\mathrm{T}}$ concentration was very high at site $\mathrm{HG} 1$, but the maximum in $\mathrm{Hg}_{\mathrm{T}}$ concentration occurred at sample site $\mathrm{HG} 1.5$ in the middle of the wetland area. The high concentration of $\mathrm{Hg}_{\mathrm{T}}$ and isotopic chemistry at this site indicates that a significant input of connate groundwater into the creek at this location contributes to the high $\mathrm{Hg}$ concentration in water. At site HG1, just downstream from the thermal water input from the Turkey Run mine, water sampled in June 2010 was almost entirely composed of thermal-water effluent. During the storm sampling in March 2011, which resulted in the highest flows of the winter, thermal effluent was virtually undetectable at site HG1, and the water was all meteoric. During the May 2011 sampling event, the input of connate groundwater in the middle of the wetland area at site HG1.5 was dominant. Discharge from the adit and runoff from the mine contributes to the high $\mathrm{Hg}$ concentration at site HG1 under both high and low-flow conditions.

\section{East Fork: Background}

$\mathrm{Hg}$ levels in waters collected from the East Fork of Harley Gulch, where no mining has occurred, were as high as 32.8 parts per trillion (pptr). These levels of $\mathrm{Hg}$ in water are significantly higher than regional background $\mathrm{Hg}$ concentrations, which range from 4-7 pptr. These anomalous $\mathrm{Hg}$ concentrations are partially explained by the abundance of $\mathrm{Hg}$-enriched groundwater in Harley Gulch.

\section{Sites HG4-HG7}

Downstream from the wetland, the aqueous concentration of $\mathrm{Hg}_{\mathrm{T}}$ decreased, but remained above background levels as another input of connate groundwater occurs in the creek segment between sample sites HG4 and HG7. The input of connate groundwater in this segment 
of the creek is reflected in the increase in dissolved constituents characteristic of the connate groundwater, such as sulfate $\left(\mathrm{SO}_{4}\right)$, chloride $(\mathrm{Cl})$ and magnesium $(\mathrm{Mg})$. Stable-isotope data for heavy isotopes $\delta^{18} \mathrm{O}$ and $\delta^{2} \mathrm{D}$ also confirm two areas of input of connate groundwater into Harley Gulch: the creek segment in the West Fork near sample site HG1.5 and the segment between sample sites HG4 and HG7. Downstream from the second area of input of connate groundwater, both $\mathrm{Hg}_{\mathrm{F}}$ and $\mathrm{Hg}_{\mathrm{T}}$ concentrations decrease similarly, but the percentage of $\mathrm{Hg}$ in the filtered fraction increases. The decreases in $\mathrm{Hg}_{\mathrm{T}}$ and $\mathrm{Hg}_{\mathrm{F}}$ between sample sites $\mathrm{HG} 5$ and $\mathrm{HG} 7$ suggests that this second source of connate groundwater to Harley Gulch is distinct from the Hg-enriched source that enters the middle of the wetlands at sample site HG1.5. During low-flow conditions in June 2010, input of connate groundwater increased from sample site HG4 and reached a maximum near sample site $\mathrm{HG} 7$, where it dominated creek water chemistry. Waters collected from sample site HG7 during the June 2010 sampling event were the heaviest isotopically and contained high concentrations of $\mathrm{Cl}$ and $\mathrm{SO}_{4}$, constituents that are characteristically high in the connate groundwater. Both above and below sample site $\mathrm{HG} 7$, the amount of connate groundwater in the creek water decreased.

\section{Sites HG8-HG10}

Sediment with high Hg concentration is present throughout the West Fork of Harley Gulch below the mine and in the upper part of the Harley Gulch main stem to just above sample site HG10. At the sample site furthest downstream, $\mathrm{HG10}, \mathrm{Hg}$ concentration is at background levels, as are cobalt (Co), nickel (Ni), and tungsten (W), indicating that the sediment is not significantly contaminated with $\mathrm{Hg}$ from the mine. 
This report summarizes data obtained from field sampling of water, sediment, and biota in Harley Gulch, downstream from the Abbott-Turkey Run mine. Our results permit an assessment of the chemical constituents that may elevate levels of MMeHg in Harley Gulch and MMeHg uptake by biota, as well as an evaluation of the effectiveness of the clean-up of the Turkey Run and Abbot mines. The authors of this study followed an established sampling protocol adapted for the Cache Creek watershed by the USGS (Suchanek et al, 2010).

\section{Mining History and Geology of the Abbott-Turkey Run Mine}

Information about the Abbott-Turkey Run mine is summarized below (Churchill and Clinkenbeard (2003); and other references, as cited).

The Abbott-Turkey Run Mine, located in Lake County along State Highway 20 about 24 miles west of Williams, was discovered in 1862 . Production began in the early 1870 s and continued intermittently until 1971, when the mine was shut down. Total production during the life of the mine is estimated to be between 50,000 and 60,000 flasks $(1,725,000-2,070,000 \mathrm{~kg})$ of Hg (U.S. Bureau of Mines, 1965).

The Abbott mine is within rocks of the early Cretaceous to late Jurassic Great Valley Sequence. The sequence consists of marine shales, mudstones, sandstones, and occasional conglomerates. Lenses of detrital serpentinite also occur in some areas, including at the Abbott mine, where serpentinite is the dominant country rock. The host rock for the $\mathrm{Hg}$ ore at the Abbott mine is a silica-rich variety of silica carbonate rock composed of opal, chalcedony, quartz, magnesite, and some calcite (Moisseeff, 1966). Locally, there is a post-mining efflorescence of epsomite $\left(\mathrm{MgSO}_{4} \cdot 7 \mathrm{H}_{2} \mathrm{O}\right)$ (Watts, 1893). $\mathrm{Hg}$ is present in the serpentinite country rock at concentrations ranging from 0.1 to $0.2 \mu \mathrm{g} / \mathrm{g}$, and the background GVS sediments contain 0.05$0.11 \mu \mathrm{g} / \mathrm{g} \mathrm{Hg}$ (Holloway et al., 2009).

The ore at the Abbott mine consisted primarily of cinnabar, which occurred as fracture fillings in silicified and altered serpentine breccia (Wiebelt, 1949). Ore occurred in dikes and sills of the altered serpentinite and in tabular ore bodies along contacts, faults, and fault intersections (U.S. Bureau of Mines, 1965). The ores were processed in a rotary furnace and tailings were disposed of in the upper part of Harley Gulch. Hg phases present in the tailings at the Turkey Run mine, which were processed in a retort, include cinnabar and metacinnabar (Kim and others, 2004). Thermal water encountered during underground mining at the Turkey Run mine has resulted in the continuous release of thermal water from the partially collapsed Turkey Run adit. The thermal water contains low $\mathrm{Hg}$ and $\mathrm{MMeHg}$ water at the mine portal but has very high $\mathrm{Hg}$ and $\mathrm{MMeHg}$ concentrations after it flows through and reacts with tailings below the adit (Rytuba, 2000). The thermal water flows into the upper part of Harley Gulch, where it accounts for most of the flow during the dry season, even though the flow of thermal water is low at 40 liters/minute (Goff and Janik, 1993). During the dry season, surface flow extends for less than $0.5 \mathrm{~km}$ downstream from where the thermal water first enters the West Fork of Harley Gulch.

\section{Sample Locations and Methods}

\section{Sample Locations and Conditions: Water and Sediment}

Samples were collected to assess the concentration of $\mathrm{Hg}$ and biogeochemically relevant constituents in water and sediment in Harley Gulch. Water, sediment, and biota were sampled from Harley Gulch downstream from the mine three years after cleanup of the mine had been 
completed. Water and sediment samples were collected under low- and high-flow conditions in 2010 and 2011. Water sample site locations are shown in figures 1 and 2 and are listed in table 1. Water flows into Harley Gulch from two separate drainages, termed here the East Fork and the West Fork. Sample site HG1 is in the upper most part of the West Fork of Harley Gulch at the culvert under State Highway 20, immediately downstream from the mine (fig. 3). Biota site HG8-07 is in the wetland downstream from this site (fig. 4). Sample site HG1.5 is in the in the middle of the wetlands in the West Fork along State Highway 20 between the culvert and the headwaters of Harley Gulch Canyon. The biota sites UDUP and UDLW also are located in the wetlands (figs. 5 and 6). Sample site HG3 in the East Fork of Harley Gulch provided data on background concentrations of $\mathrm{Hg}$ because there was no mining in this part of the watershed (fig. 7). Sample site HG2 is along State Highway 20 in the West Fork of Harley Gulch at the end of the wetland and $200 \mathrm{~m}$ upstream from the confluence of the East and West Forks (fig. 8).

Sediment samples 10HG20-23S were collected in the West Fork just above the confluence of the East and West Forks of Harley Gulch (figs. 9 and 10). Sample site HG4 is in the headwaters of Harley Gulch at a pool located just below the confluence of the East and West Forks and (figs. 11 and 12). Sample sites HG5-HG10 are downstream in Harley Gulch where it enters a canyon, and samples were taken at regularly spaced intervals of about $1 \mathrm{~km}$ (figs. 13-17).

Water and sediment were collected during five sampling events from 2010 through 2011. Two sampling events occurred under low-flow conditions in 2010 and one in 2011, and two high-flow sampling events occured in 2011, with the March 2011 sampling occurring during the largest storm of the 2010-2011 water year.

\section{Sample Locations and Conditions: Biota}

All biota samples collected in 2007, 2008, 2010, and 2011 were within Harley Gulch. Sites sampled within the Harley Gulch wetlands (figs. 1, 3-6) included HG1, 2, and 2a, all sampled in 2008, 2010, and 2011. In addition, one site, HG8-07, was sampled only in 2007, and sites UDLW and UDUP were sampled only in 2010. One site sampled all 4 years was the East Fork of Harley Gulch (HG3) (fig. 7). Site HG4 was sampled in 2007, 2010, and 2011 (fig. 11). Site HG5 (fig. 13) was sampled all four years, HG6 was sampled in 2007 and 2010 (fig. 14), and HG7 was sampled all four years (fig. 15). HG8 was sampled in 2008 and 2010 (fig. 15), but the fish site, HG8A, was sampled only in 2010 (fig. 16). The remaining six sites (HG9-14) were sampled in 2008 and 2010 (table 2, figs. 2, 17, and 18).

As part of a study in 1997 and 1998, foothill yellow-legged frogs were collected from three reference sites: Bear Creek at Brim Road (BRIM), Spanish Creek (SPCR), and East Fork of Middle Creek (EFMC) (fig. 19). Data on frogs from these sites, located in the upper reaches of the Cache Creek watershed, presumably above sources of both anthropogenic and natural $\mathrm{Hg}$ (Hothem and others, 2010), are presented for comparison purposes.

\section{Field Sampling Methods}

\section{Sediments}

Wet-sediment samples were collected from Harley Gulch and placed in polycarbonate jars (100 ml capacity) for analysis of total $\mathrm{Hg}\left(\mathrm{Hg}_{\mathrm{T}}\right)$ and $\mathrm{MMeHg}$. The samples were frozen with dry ice immediately after collection (freezing time approximately 10-20 minutes) and kept

frozen until shipped overnight on dry ice to the analytical laboratory. The temperature of samples 
arriving at the analytical facilities ranged from 1 to $4{ }^{\circ} \mathrm{C}$, which is within the limits specified in USEPA Method 1631E.

Another sediment sample was collected in a Ziploc ${ }^{\circledR}$ bag for analysis of major and minor elements and was stored at ambient temperature.

\section{Water}

Stream-water samples were collected in the field with a peristaltic pump using ultraclean tubing and an inline filter with $0.45 \mu \mathrm{m}$ openings. Filtered water samples were collected for analysis of anions by ion chromatography, alkalinity by titration, and major and minor elements using inductively coupled plasma-mass spectrometry (ICP-MS) and inductively coupled plasmaatomic emission spectrometry (ICP-AES) analysis. An unfiltered sample also was analyzed using both ICP-MS and ICP-AES.

Samples for major and minor element determinations were acidified to $\mathrm{pH}<2$ with tracemetal (Ultrex, J.T. Baker)-grade $\mathrm{HNO}_{3}$ and were stored in acid-washed, high-density polyethylene (HDPE) bottles. Subsamples for anion and alkalinity measurements were filtered, stored in HDPE bottles, and chilled to approximately $4{ }^{\circ} \mathrm{C}$ until analysis, in accordance with USGS protocols for trace metals (http://pubs.water.usgs.gov/twri9A).

Samples for DOC analysis were filtered using 0.45 micron disposable borosilicate filters and stored in $40 \mathrm{~mL}$ amber ICHEM glass vials. Shortly after collection DOC samples were acidified to $\mathrm{pH}$ less than 2 with $\mathrm{HCl}$ and kept on ice and refrigerated until analyzed.

Samples for stable-isotope analysis were collected as a grab sample directly from the stream into clear 40mL ICHEM glass vials. Stable-isotope samples were stored at ambient temperature until anlyzed.

Water variables, including $\mathrm{pH}$, conductivity, temperature, dissolved oxygen, and oxidation-reduction potential (ORP) were measured in the field using a battery-powered Hydrolab sonde. Measurements were taken by placing the probe directly into the flowing stream water.

Samples for total $\mathrm{Hg}\left(\mathrm{Hg}_{\mathrm{T}}\right)$ and $\mathrm{MMeHg}$ analyses were collected with no headspace in trace-metal-free-certified $250 \mathrm{~mL}$ bottles (Nalgene ICHEM). The MMeHg bottles contained a preservative of certified ultra-clean $\mathrm{HCl}$ provided by Frontier Global Sciences and Brooks Rand Labs, the analytical laboratories. Sampling for $\mathrm{Hg}_{\mathrm{T}}$ analysis followed ultra-clean sampling and handling protocols (Bloom, 1995; Gill and Fitzgerald, 1987) during the collection of field samples and analysis to avoid introduction of Hg. Samples were kept on ice until shipped. Samples were shipped on ice packs and arrived the next morning at the analytical facilities at temperatures ranging from 1 to $4^{\circ} \mathrm{C}$, as specified by USEPA Method 1631E to minimize biologically induced phase changes and $\mathrm{MMeHg}$ degradation. During every sampling event, a field blank was collected by processing ultra-clean water provided by the analytical laboratories and collecting the same subsamples (except for alkalinity) following the same procedures as used for the field samples. Laboratory blanks and acid blanks were processed periodically to determine whether our equipment, containers, reagents, and procedures introduced any significant contamination.

\section{Invertebrates}

The target macroinvertebrates for this study were predatory insects. Depending on their abundance and availability at each sample site, invertebrates collected included larval skimmer and darner dragonflies (Order Odonata, families Libellulidae and Aeshnidae, respectively) and 
adult water striders (Order Hemiptera, family Gerridae) in 2007. These taxa also were collected at Harley Gulch on October 16, 2002. Taxa collected in 2008, 2010, and 2011 included adult water striders and giant water bugs (Order Hemiptera, family Belostomatidae), two families of Coleoptera [larval water scavenger beetles (family Hydrophilidae), and adult predaceous diving beetles (family Dytiscidae)], two families of larval damselflies [Order Odonata: narrow-winged damselflies (family Coenagrionidae) and spread-winged damselflies (family Lestidae)], two families of larval dragonflies [Order Odonata: skimmer dragonflies (family Libellulidae) and darner dragonflies (family Aeshnidae]), and larval dobsonflies (Order Megaloptera, family Corydalidae).

Invertebrates were collected from all sites, using dip nets and by hand, and placed in Ziploc ${ }^{\circledR}$ plastic bags with native water. Samples were kept in a cooler and allowed to depurate in native water on wet ice for 4-24 hours before processing. Individuals were sorted by family and placed in disposable dishes using Teflon-coated forceps, or by hand while wearing disposable latex gloves. Organisms were rinsed thoroughly with deionized water, patted dry with a clean paper towel, and composited by family, with the goal of obtaining a minimum of $1 \mathrm{~g}$ wet biomass per sample. Each sample consisted of 1-40 individuals of the same family $(0.39-4.56 \mathrm{~g}$ total mass). Sample mass was determined using an electronic balance ( $\pm 0.01 \mathrm{~g})$. Samples were placed into chemically cleaned glass jars with Teflon-lined lids and were stored frozen for up to 5 months until they could be shipped to the Brooks Rand Laboratory in Seattle, Wash., for $\mathrm{MMeHg}$ and $\mathrm{Hg}_{\mathrm{T}}$ analysis.

\section{Frogs}

During daylight hours in 2007 and 2008, foothill yellow-legged frogs were collected from Harley Gulch by hand or with a net. Individual frogs were placed in their own plastic Ziploc ${ }^{\circledR}$ bag on wet ice. For each specimen, the site, date, time, and collector were recorded on each specimen bag. Frogs were euthanized humanely on the same day of collection, and were kept frozen until they could be processed within 2 days after collection. Foothill yellow-legged frogs were collected from Harley Gulch and the three reference sites in 1997 and 1998 using the same collection techniques (Hothem and others, 2010).

Each specimen was processed using chemically clean tools, weigh dishes, and disposable latex gloves to avoid cross contamination. Each specimen was thawed, rinsed with tap water to remove debris, and then thoroughly rinsed with deionized water. Excess moisture was removed by patting the specimen dry with a clean paper towel. The total mass $( \pm 0.01 \mathrm{~g})$ for each specimen was determined using an electronic balance. The length from the tip of the snout to the urostyle [snout-vent length $(\mathrm{SVL})]( \pm 0.1 \mathrm{~mm})$ was measured using calipers, and each specimen was examined for gross abnormalities. The digestive tract was removed, and the stomach contents were identified and discarded. The carcass, including the stripped and rinsed digestive tract, was placed in a labeled chemically clean jar $\left(\mathrm{VWR}^{\circledR}\right.$ TraceClean ${ }^{\circledR}$, which was then sealed with Parafilm ${ }^{\circledR}$ and frozen at $-20^{\circ} \mathrm{C}$, pending chemical analysis. Carcasses of frogs collected in 2008 were analyzed for $\mathrm{MMeHg}$ at Brooks Rand Laboratory within 5 months of collection.

\section{Fish}

In 2010, California roach (Hesperoleucus symmetricus) were collected with a net from site HG8a in Harley Gulch. Fish were placed in a plastic Ziploc ${ }^{\circledR}$ bag on wet ice. Fish were euthanized humanely the same day they were collected and were kept frozen until they could be processed within 2 days after collection. Each specimen was processed using chemically clean 
tools, weigh dishes, and disposable latex gloves to avoid cross contamination. Each specimen was thawed, rinsed with tap water to remove debris, and then thoroughly rinsed with deionized water. Excess moisture was removed by patting the specimen dry with a clean paper towel. The total mass $( \pm 0.01 \mathrm{~g})$ was determined for each specimen using an electronic balance. The standard length from the tip of the snout to the posterior end of the last vertebra, and total length fromthe tip of the snout to the end of the caudal fin was measured. Each specimen was further examined for gross abnormalities. The digestive tract was removed, and the stomach contents were identified and discarded. The total carcass, including the stripped and rinsed digestive tract, was placed in a labeled chemically clean jar $\left(\mathrm{VWR}^{\circledR} \operatorname{TraceClean}^{\mathbb{B}}\right)$, which was then sealed with Parafilm ${ }^{\circledR}$ and frozen at $-20^{\circ} \mathrm{C}$, pending chemical analysis within 30 days.

\section{Analytical Methods}

\section{Sediments}

Multielement analyses for all sediments were performed in the laboratories of ALS Chemex. Bulk samples were ground in a zirconia ring mill and subjected to a neartotal four-acid digestion. Major elements were determined by ICP-AES. Minor elements, other than $\mathrm{Hg}$, were determined by ICP-MS. Hg was determined by cold vapor atomic absorption spectroscopy (CVAAS) following methods similar to those described by Crock (1996) and O'Leary and others (1996).

$\mathrm{Hg}$ and $\mathrm{MMeHg}$ analyses for all wet sediments were done at Frontier Global Sciences and Brooks Rand LABS. For total $\mathrm{Hg}$, the sediment was leached with cold aqua regia, followed by stannous chloride $\left(\mathrm{SnCl}_{2}\right)$ reduction, two-stage gold amalgamation, and cold vapor atomic fluorescence spectroscopy (CVAFS) detection. MMeHg was obtained by acid bromide/methyl chloride extraction followed by aqueous phase ethylation, isothermal gas chromatographic (GC) separation, and CVAFS detection (Horvat and others, 1993). Results were reported on both a wet- and dry-weight basis and are listed in table 2.

\section{Waters}

Alkalinity as $\mathrm{CaCO}_{3}$ was determined in the laboratory by titration with $\mathrm{H}_{2} \mathrm{SO}_{4}$, using Gran's technique (Orion Research, Inc., 1978), within 2-4 days after sample collection. Sulfate, chloride, nitrate, and fluoride concentrations were determined by ion chromatography (Fishman and Pyen, 1979) by the USGS analytical laboratory at the Denver Federal Center.

Cations were analyzed by ICP-AES and ICP-MS at USGS laboratories at the Denver Federal Center in Denver, Colorado. Ion chromatography and alkalinity analyses were performed in USGS laboratories at the Denver Federal Center. Duplicate water samples, blank samples, and USGS Water Resource Division standard reference waters were analyzed with the data set.

At both Frontier Global Sciences and Brooks Rand Labs, samples were handled in a Class-100 clean-air station that was monitored routinely for low levels of total gaseous $\mathrm{Hg}$. An ultra-clean $\mathrm{Hg}$ trace-metal protocol was followed, including the use of rigorously cleaned and tested Teflon ${ }^{\mathrm{TM}}$ equipment and sample bottles and prescreened and purified reagents. Laboratory atmosphere and water supply also were routinely monitored for low 
levels of Hg. Primary standards used in the laboratory were NIST-certified, or traceable to NIST-certified materials. Following USEPA Method 1631, MMeHg standards were made from pure powder and calibrated against an NBS-3133 certified $\mathrm{Hg}$ (II) standard. Standards were cross-verified by daily analysis of Certified reference material (CRM) DORM-2 (National Research Council of Canada Institute for National Measurement Standards, 1999). Total $\mathrm{Hg}$ was determined by bromine monochloride ( $\mathrm{BrCl})$ oxidation followed by Tin(II) Chloride $\left(\mathrm{SnCl}_{2}\right)$ reduction, two-stage gold amalgamation, and detection by CVAFS (Bloom and others, 1988). MMeHg was liberated from water using an all-Teflon ${ }^{\circledR}$ distillation system. Distilled samples were analyzed using aqueous phase ethylation with purging onto Carbotrap ${ }^{\mathrm{TM}}$, isothermal GC separation, and CVAFS detection (Bloom, 1989). To address accuracy and precision, quality assurance measures were employed with the following minimum frequencies: laboratory duplicates, one per ten samples; method blanks, three per analytical batch; filtration blanks, one per ten samples; and spike recovery or standard reference material, one per ten samples.

Since May 1, 1990, hydrogen-isotope-ratio analyses have been performed using a hydrogen equilibration technique (Coplen and others, 1991; Revesz and Coplen, 2008a), rather than the zinc technique used prior to that date (Kendall and Coplen, 1985). The hydrogen equilibration technique measures deuterium activity, whereas the zinc technique measures deuterium concentration.

For the majority of Water Resources Division (WRD) samples, the difference in reported isotopic compositions between the two techniques is not significant. However, in brines, the difference may be significant (Sofer and Gat, 1972, 1975). Reported delta H-2 values of activity are more positive than delta $\mathrm{H}-2$ values of concentration, and this difference is proportional to molalities of the major dissolved solids. Some examples of the differences between activity ratios and concentration ratios for delta $\mathrm{H}-2$ in 1 molal salt solutions are as follows (Horita and others, 1993). The data for individual salts may be multiplied by molality to obtain adjustments to delta values based on concentration. Water samples are measured for delta O-18 using the CO2 equilibration technique of Epstein and Mayeda (1953), which has been automated (Revesz and Coplen, 2008b). Therefore, both oxygen and hydrogen isotopic ratio measurements are reported as activities. Reporting of Stable Hydrogen and Oxygen Isotope Ratios Oxygen and hydrogen isotopic results are reported in parts per thousand (per mill) relative to VSMOW (Vienna Standard Mean Ocean Water) and normalized (Coplen, 1994) on scales such that the oxygen and hydrogen isotopic values of SLAP (Standard Light Antarctic Precipitation) are -55.5 per mill and -428 per mill, respectively. The 2-sigma uncertainties of oxygen and hydrogen isotopic results are 0.2 per mill and 2 per mill, respectively, unless otherwise indicated. This means that if the same sample were resubmitted for isotopic analysis, the newly measured value would lie within the uncertainty bounds 95 percent of the time.

\section{Frogs, Fish, and Invertebrates}

\section{Dry-Weight Correction (percentage Solids) USEPA Method 160.3 (SOP BR-1501)}

A solid sample was homogenized and an aliquot was measured into a pre-weighed vessel, dried in an oven overnight, weighed again, and the percentage of dried solid material was calculated. This standard operating procedure (SOP) is analogous to USEPA method 160.3 (Residue, total). 
Sample Homogenization (SOP BR-0106)

Once thawed, the samples were homogenized using pre-cleaned commercial-grade homogenization equipment. A homogenization blank was collected after cleaning the equipment and prior to homogenization of the samples. The blank was digested as a tissue sample and analyzed along with the associated homogenates. The result for the homogenization blank was less than one-tenth of the lowest sample result, indicating that no significant contamination occurred during homogenization.

\section{Total Mercury (SOP BR-0002)}

Total mercury was analyzed as outlined in EPA method 1631 (SOP BR-0002). Samples were digested in nitric acid $\left(\mathrm{HNO}_{3}\right)$ and sulfuric acid $\left(\mathrm{H}_{2} \mathrm{SO}_{4}\right)$, and then further oxidized with bromine monochloride $(\mathrm{BrCl})$. Samples were analyzed with stannous chloride $\left(\mathrm{SnCl}_{2}\right)$ reduction, single gold amalgamation, and CVAFS detection using a BRL Model III CVAFS Mercury Analyzer.

\section{Monomethyl Mercury, USEPA Draft 1630 Modified (SOP BR-0011)}

In 2008, all biological samples were analyzed for MMeHg. Samples were prepared by potassium hydroxide $(\mathrm{KOH})$ methanol $\left(\mathrm{CH}_{3} \mathrm{OH}\right)$ digestion. Samples were analyzed by aqueousphase ethylation, Tenax trap collection, GC separation, isothermal decomposition, and CVAFS using a BRL Model III CVAFS Mercury Analyzer. All sample results for low-level Hg analysis were blank corrected, as outlined in the calculations section of Brooks Rand SOP BR-0011.

\section{Quality Assurance/Quality Control}

At Brooks Rand, duplicate samples were analyzed for $\mathrm{Hg}$ at a rate of 5 percent, with at least one duplicate per matrix per analytical run to estimate the precision of the methods. Duplicates were analyzed for $\mathrm{MMeHg}$ with relative percent difference between duplicate determinations (RPDs) ranging from 0.7 to 19 percent, all within the allowable criteria of 35 percent. For $\mathrm{Hg}_{\mathrm{T}}$, RPDs ranged from 1 to 21 percent, within the acceptable criterion of less than 30 percent.

To assure that no analyte was added during the processing of the sample, procedural blanks were analyzed at a rate of 5 percent of the total samples, with at least one per matrix per analytical run. The averages for $\mathrm{MMeHg}$ blanks ranged from 0.0 to $0.06 \mathrm{ng} / \mathrm{g}$, less than the acceptable criterion of $2.0 \mathrm{ng} / \mathrm{g}$, or twice the minimum detection limit. The averages for $\mathrm{Hg}_{\mathrm{T}}$ blanks ranged from 0.004 to $0.04 \mathrm{ng} / \mathrm{g}$, less than the acceptable criterion of $0.08 \mathrm{ng} / \mathrm{g}$.

Spiked samples were analyzed at a rate of 5 percent, with at least one spike per matrix per analytical run. Spikes were samples fortified with a known quantity of analyte and were analyzed as part of the run. Matrix spikes for $\mathrm{MMeHg}$ ranged from 97 to 130 percent, and all were within the acceptable criteria (70-130 percent recovery). Duplicate spike RPDs ranged from 0.1 to 22 percent, and all met the criterion of an $\mathrm{RPD}<35$ percent. For $\mathrm{Hg}_{\mathrm{T}}$, matrix spikes ranged from 79 to 115 percent; all were within the acceptable criterion (70-130 percent recovery). Duplicate spike RPDs ranged from 0.3 to 18 percent, and all met the criterion of an RPD $<30$ percent.

CRMs were analyzed at a rate of 5 percent to insure that the method worked with naturally incorporated $\mathrm{Hg}$. In 2008, two preparations of CRM-3 produced consistently low recoveries (55-62 percent). Both preparations were analyzed within 28 hours of preparation, and, as demonstrated by further reanalysis, the CRM preparations had not been fully digested to allow 
for a complete extraction of the $\mathrm{MMeHg}$ present. The CRM re-preparations produced acceptable recoveries of 92 percent and 100 percent. In 2010 and 2011, CRMs for MMeHg had recoveries ranging from 78 to 116 percent, within the acceptable criterion of 65 to 135 percent. For $\mathrm{Hg}_{\mathrm{T}}$, recoveries ranged from 97 to 115 percent, within the acceptable criterion of 75 to 135 percent.

\section{Statistical Analyses}

Because collection of one composite sample of each invertebrate taxon per site precluded statistical comparisons, only qualitative comparisons were made with previous data and with results from a reference site. Total $\mathrm{Hg}$ concentrations in frogs from different sites sampled in 2007 were compared using one-way analysis of variance (ANOVA). When differences among sites were significant, the Tukey pairwise multiple comparison procedure was used. $\mathrm{Hg}$ concentrations in frogs were compared using $\log _{10}$-transformed $\mathrm{Hg}$ concentrations (wet-weight basis), and where more than one sample was collected per site, geometric means were calculated. With the exception of HG8, only one frog was collected from each site sampled in 2008; therefore, statistical comparisons between sites were not made. Frogs collected in 2008 were analyzed only for $\mathrm{MMeHg}$. To compare $\mathrm{Hg}_{\mathrm{T}}$ concentrations in frogs collected in 2008 with frogs from previous years and from reference sites, the MMeHg concentrations in the 2008 frogs were estimated. Since frogs collected in 2007 were found to contain about 50 percent $\mathrm{MMeHg}$, $\mathrm{Hg}_{\mathrm{T}}$ in frogs in 2008 was calculated by multiplying the MMeHg concentration by 1.98 . The body mass and SVL of the frogs were compared, separated by year and by sex using one-way ANOVA. Where normality failed, Kruskal-Wallis one-way analysis of variance on ranks was used. The relationship between both SVL and body mass and $\mathrm{Hg}_{\mathrm{T}}$ concentration was evaluated using linear regression. The significance level for all tests was $\alpha=0.05$.

\section{Results}

\section{$\mathrm{Hg}$ and MMeHg in Waters}

Concentrations of $\mathrm{Hg}$ and $\mathrm{MMeHg}$ in waters collected from Harley Gulch are listed in table 3 and shown in figures 20, 21, and 22. Concentrations of $\mathrm{Hg}_{\mathrm{T}}$ measured during the highflow sampling event in March 2011 exceeded levels measured during all other sampling events by several orders of magnitude (fig. 20). This high-flow event was the largest storm of the 2010 2011 winter season. $\mathrm{Hg}_{\mathrm{T}}$ concentrations measured during the second high-flow sampling event in June 2011 are lower and comparable to levels measured during low-flow conditions. Runoff during this event was minimal as rainfall was relatively low, and the surface soils in the watershed had dried during the dry period before this late-season storm. Concentrations of $\mathrm{Hg}_{\mathrm{T}}$ follow a similar trend moving downstream during both low- and high-flow conditions. $\mathrm{Hg}_{\mathrm{T}}$ levels are highest at sample sites HG1, HG1.5 and HG2, in the west fork of Harley Gulch, immediately downstream from the Abbott-Turkey Run mine. $\mathrm{Hg}_{\mathrm{T}}$ levels at sample site $\mathrm{HG} 1$ under high-flow conditions were extremely high, 429,000 ng/L, but during all other sampling events $\mathrm{Hg}_{\mathrm{T}}$ levels were lower (301-825 ng/L), but still highly elevated. During the May 2011 sampling event, $\mathrm{Hg}_{\mathrm{T}}$ levels measured at sample site $\mathrm{HG} 1.5$ in the middle of the wetland area were very high $(2,300 \mathrm{ng} / \mathrm{L})$, and were higher than $\mathrm{Hg}_{\mathrm{T}}$ levels at site $\mathrm{HG} 1$ immediately downstream from the mine $(624 \mathrm{ng} / \mathrm{L})$. In the east fork of Harley Gulch (sample site HG3), where no mining occurred, $\mathrm{Hg}_{\mathrm{T}}$ levels (4.08-32.8 $\mathrm{ng} / \mathrm{L}$ ) for all sampling events were several orders of magnitude lower than levels measured in the West Fork and reflect background 
concentrations (fig. 20). Downstream from the confluence of the highly contaminated West Fork and the relatively clean East Fork, $\mathrm{Hg}_{\mathrm{T}}$ levels in waters were elevated, but declined systematically downstream to site HG10, where the lowest concentration $(18.3 \mathrm{ng} / \mathrm{L})$ was measured (fig. 20).

Filtered $\mathrm{Hg}\left(\mathrm{Hg}_{\mathrm{F}}\right)$ concentrations in waters sampled under high-flow conditions were generally higher or comparable to $\mathrm{Hg}_{\mathrm{F}}$ concentrations in water sampled under low-flow conditions (fig. 21). Concentrations of $\mathrm{Hg}_{\mathrm{F}}$ were highest in the West Fork of Harley Gulch at sample sites HG1, HG1.5, and HG2. $\mathrm{Hg}_{\mathrm{F}}$ levels were slightly elevated in the East Fork of Harley Gulch at sample site HG3 under high-flow conditions in the March 2011 sampling event. In general, the concentration of $\mathrm{Hg}_{\mathrm{F}}$ systematically decreases downstream from the confluence of the East and West Forks of Harley Gulch at site HG4, to the most downstream site sampled, HG10 (fig. 21). During the May 2011 sampling event, $\mathrm{Hg}_{\mathrm{F}}$ concentration at sample site HG1.5 was considerably higher than at sample site $\mathrm{HGl}$, and the percentage of dissolved $\mathrm{Hg}\left(\mathrm{Hg}_{\mathrm{F}} / \mathrm{Hg}_{\mathrm{T}}\right)$ increased downstream from sample site HG1 to HG1.5. Under low-flow conditions at site HG1, the percentage of dissolved $\mathrm{Hg}$ was very high in June of 2010 (78.4 percent), and considerably less in May of 2011 (28.8 percent). During the high-flow sampling event of March 2011, when meteoric input dominated Harley Gulch water chemistry, the percentage of dissolved $\mathrm{Hg}$ at site HG1 was extremely low ( 0.79 percent) indicating that essentially all of the $\mathrm{Hg}$ was being transported in the particulate phase. During low-flow conditions in June $2010, \mathrm{Hg}_{\mathrm{F}}$ decreased systematically downstream from sample site $\mathrm{HG} 5$ to $\mathrm{HG} 10$, mirroring the decline of $\mathrm{Hg}_{\mathrm{T}}$ (fig. 21).

Concentrations of $\mathrm{MMeHg}$ in unfiltered water varied considerably depending on flow conditions and distance downstream from the mine (fig. 22). The highest MMeHg concentration measured(15.8 ng/L) was at sample site HG1, just below the mine, during the March 2011 highflow event. The highest MMeHg concentrations were measured at site HG1 for all sampling events, except for the June 2010 sampling, when the highest concentration occurred at the end of the wetland area at site HG2. For all sampling events, the lowest MMeHg concentrations measured always occurred in the East Fork of Harley Gulch at sample site HG3, the East Fork Harley Gulch reference site. Concentrations of MMeHg levels were highest in the West Fork of Harley Gulch and declined downstream from sample site HG1 to sample site HG4, located below the confluence of the East and West Forks of Harley Gulch. Downstream from the confluence, $\mathrm{MMeHg}$ concentration increased from sample site HG5 to sample site HG7 during the low-flow sampling events (fig. 22). Further downstream from sample site HG7, MMeHg levels declined systematically to sample site $\mathrm{HG10}$. As a percentage of $\mathrm{Hg}_{\mathrm{T}}, \mathrm{MMeHg}$ levels are higher during low-flow conditions (table 3).

\section{Hg and MMeHg in Sediments}

Previous work in 2003 indicated $\mathrm{Hg}$ concentrations as high as $100 \mathrm{ppm}$ in sediments collected from the West Fork of Harley Gulch prior to cleanup of the mine (Ichikawa and Jakl, 2004). Sediment from the active channel of Harley Gulch was collected during two low-flow sampling events in 2010 and one in 2011, four and five years respectively after cleanup of the mine had been completed in 2007. For this study, sediment was analyzed for $\mathrm{Hg}$ and $\mathrm{MMeHg}$; the results are listed in table 2 and shown in figs. 23 and 24. Storm sediment deposited outside and above the active channel of Harley Gulch during high-flow events in the winter of 2011 also was sampled and analyzed. The results for storm sediment and sediment from the active channel are listed in table 5 and shown in fig. 24. 
The Hg concentrations in sediment from the active channel remain elevated and consistent across sampling events (fig. 23). $\mathrm{Hg}$ concentrations in sediment are highest at sample site HG1, immediately downstream from the mine. At sample site HG1, $\mathrm{Hg}$ concentrations in sediment in the active channel ranged from 44,700 -78,300 $\mathrm{ng} / \mathrm{g}(\mathrm{ppb})$ the concentration was greater than $100,000 \mathrm{ng} / \mathrm{g}$ in storm sediment (table 4). Concentrations of $\mathrm{Co}, \mathrm{Ni}$, and $\mathrm{W}$ also are elevated and indicate that tailings or mineralized rock comprise a significant portion of the sediment (table 5). Sediment samples from the active channel collected during the first low-flow sampling event in June 2010 showed a decrease in $\mathrm{Hg}$ downstream from sample site HG1 (fig. 23). Sediment collected at sample site HG4 during the second low-flow sampling event in September 2010 contained $\mathrm{Hg}$ concentration that was considerably lower, but still elevated. Sediment samples collected during the third low-flow sampling event in May 2011 showed an irregular trend, with highly elevated $\mathrm{Hg}$ levels downstream from the confluence of the East and West Forks at sample sites HG5 and HG7. Samples collected from sample site HG3, the reference site in the East Fork of Harley Gulch, had much lower levels of $\mathrm{Hg}$ than did samples collected from the West Fork. In the active channel, $\mathrm{Hg}$ concentration ranges from $213-420 \mathrm{ng} / \mathrm{g}$ (table 3). In the East Fork, where there are no mines, waters contained lower concentrations of $\mathrm{Hg}, \mathrm{Co}, \mathrm{Ni}$, and $\mathrm{W}$ (table 5); however, $\mathrm{Hg}$ concentrations in the East Fork were elevated relative to regional background $\mathrm{Hg}$ levels. At the sample site furthest downstream, HG10, sediment in the active channel primarily is derived from Great Valley Sequence siltstone and sandstone present in bedrock exposed along the creek bank. Low concentrations of $\mathrm{Co}, \mathrm{Ni}$, and $\mathrm{W}$, as well as near-background $\mathrm{Hg}$ levels (60-190 ng/g) indicate that the sediment in the East Fork is not contaminated with tailings (table 5).

Unlike $\mathrm{Hg}$ levels in sediments, concentrations of $\mathrm{MMeHg}$ are high in sediment samples collected at several downstream sites in Harley Gulch (fig. 23). During the first low-flow sampling event in June 2010, MMeHg concentrations were low at sample site HG1 (0.098 ng/g), immediately downstream from the mine. At sample site $\mathrm{HG} 2$, downstream from the input from the wetlands, $\mathrm{MMeHg}$ concentration in sediment was elevated $(3.79 \mathrm{ng} / \mathrm{g})$. MMeHg levels in sediment collected below the confluence of the East and West Forks of Harley Gulch at sample site HG4 were very high $(36.3 \mathrm{ng} / \mathrm{g})$, but declined to $0.89 \mathrm{ng} / \mathrm{g}$ downstream from the confluence at sample site HG5. From sample sites HG5 to HG7, MMeHg concentrations increased systematically downstream. $\mathrm{MMeHg}$ levels remained high downstream from sample sites HG7 to HG9.5, but declined at sample site HG10 (fig. 23). Sediment samples collected during the second low-flow sampling event in September 2010 at site HG4 were elevated, but were considerably lower than the results of June 2010. During the third low-flow sampling event, in May 2011, MMeHg levels were lower than concentrations at the same site during previous sampling events. During this sampling event, $\mathrm{MMeHg}$ concentrations increased from sample site HG1 to sample site HG1.5 in the middle of the wetland area, where connate groundwater enters the wetland. MMeHg levels also were elevated in sediment collected at sample site HG4 during this sampling event, but decreased to lower levels further downstream (fig. 23).

During two low-flow sampling events, sediment samples were collected to assess the concentrations of $\mathrm{Hg}$ storm sediment deposited during the winter high-flow events as compared to sediment in the active stream channel. Hg concentrations were considerably higher in storm sediment than in active-stream channel sediment at all sample sites, except HG7 (table 5, fig. 24). The highest concentrations of $\mathrm{Hg}$ in storm sediment $(136,000 \mathrm{ng} / \mathrm{g})$ occurred at site $\mathrm{HG} 20$ (about 25m upstream from sample site HG4) (table 5), and the lowest concentration (210 ng/g) occurred in storm sediment in the East Fork of Harley Gulch (table 4). 


\section{Water Chemistry}

Major- and minor-element concentrations in waters collected from Harley Gulch are listed in tables 4, 6, and 7. Waters in Harley Gulch are predominantly $\mathrm{Mg}-\mathrm{CO}_{3}-\mathrm{SO}_{4}$ waters that have elevated concentrations of $\mathrm{Ca}, \mathrm{Cl}, \mathrm{Fe}, \mathrm{Na}, \mathrm{Hg}$, Ti and W. Stream water in Harley Gulch is alkaline as a result of interaction with the serpentinite country rock.

There are three water sources in the Harley Gulch watershed. Meteoric water dominates flows in the wet season, while connate groundwater dominates flows in the dry season. These dry-season flows of connate groundwater support the abundant riparian vegetation between sample sites HG4 and HG7 (fig. 25). The third source of water, thermal water from the Turkey Run adit, dominates flows only in the upper most part of the watershed during the dry season (sample site HG1). Meteoric water is isotopically light, $\left(\delta^{18} \mathrm{O}=-8.7, \delta^{2} \mathrm{H}=-61.49\right)$ and has low concentrations of chloride and sulfate. The thermal water at the Turkey Run adit is isotopically heavy $\left(\delta^{18} \mathrm{O}=-5.8, \delta^{2} \mathrm{H}=-52.2\right)$ and has high concentrations of $\mathrm{SO}_{4}(2,020 \mu \mathrm{g} / \mathrm{L})(\mathrm{ppm}), \mathrm{Cl}(1,150$ $\mu \mathrm{g} / \mathrm{L})$, and $\mathrm{CO}_{3}(1,938 \mu \mathrm{g} / \mathrm{L})$, as well as elevated concentrations of B $(37.6 \mu \mathrm{g} / \mathrm{L}), \mathrm{Li}(1.5 \mu \mathrm{g} / \mathrm{L})$, and $\mathrm{Mg}(224 \mu \mathrm{g} / \mathrm{L})($ Goff and Janik, 1993). The connate groundwater is isotopically distinct and has the heaviest $\delta^{18} \mathrm{O}(-5.43)$ and $\delta^{2} \mathrm{H}(-48.5)$ of waters sampled in the Harley Gulch watershed (fig. 26, table 7). The connate groundwater has high concentrations of $\mathrm{SO}_{4}(1,424 \mu \mathrm{g} / \mathrm{L}), \mathrm{Cl}(874$ $\mu \mathrm{g} / \mathrm{L})$, and $\mathrm{CO}_{3}(907 \mu \mathrm{g} / \mathrm{L})$, as well as elevated concentrations of B $(21.8 \mu \mathrm{g} / \mathrm{L}), \mathrm{Li}(0.67 \mu \mathrm{g} / \mathrm{L})$, and $\mathrm{Mg}(309 \mu \mathrm{g} / \mathrm{L})$ (sample 10HG7, tables 3 and 7). The thermal water and the connate groundwater have similar suites of elements that are elevated, indicating that both are derived from the same geological source, water lodged in the Great Valley Sequence; however, the two waters can be distinguished based on isotopes and chemical concentration of selected elements. The thermal water has much higher concentrations of $\mathrm{SO}_{4}, \mathrm{Cl}$, and $\mathrm{CO}_{3}$ than the connate groundwater. The concentration of $\mathrm{Hg}_{\mathrm{F}}$ in the thermal water is very low, ranging from $2-7 \mathrm{ng} / \mathrm{L}$. The connate groundwater has much higher concentrations of $\mathrm{Hg}_{\mathrm{F}}$, ranging from 40 to $811 \mathrm{ng} / \mathrm{L}$, and as mentioned above, is isotopically heavier than the thermal water.

Thermal-water effluent from the Turkey Run mine contributes only to the flow in the upper most part of Harley Gulch and it becomes a minor component farther downstream from site HG1 owing to its relatively small volume. During the dry season, the thermal water does not flow into the lower reach of Harley below site HG2. Depending on several factors, including seasonality, temperature, and rainfall, the creek water at site HG1, located just downstream from the input of thermal water, is a variable mixture of meteoric water and thermal effluent. During the dry season, thermal water dominates water chemistry at sample site HG1; meteoric water dominates this section of the creek during the wet season. Farther downstream, at site HG1.5, thermal water is not a significant component of creek water, and instead the waters are a mixture of meteoric water and connate groundwater. The connate groundwater first enters Harley Gulch at sample site HG1.5, and then again in the stream segment between sample sites HG4 and HG7. During the dry summer season, Harley Gulch stream water is dominated by input from connate groundwater, resulting in creek water with high levels of $\mathrm{Mg}, \mathrm{SO}_{4}$, and $\mathrm{Hg}_{\mathrm{F}}$ and enrichment in the stable-isotopes $\delta^{18} \mathrm{O}$ and $\delta^{2} \mathrm{H}$. During the rainy season, meteoric water dominates Harley Gulch, and waters are isotopically light and contain high levels of particulate Hg.

Stable-isotope levels in water collected from Harley Gulch provide evidence for a complex system of connate groundwater input and mixing with meteoric water. Each sampling event produced a distinct trend line of waters moving away from the global meteoric water line (GMWL) (table 8, figs. 26 and 25). During the first low-flow sampling event in 2010 (fig. 26, data highlighted in red), waters collected at sample site HG1 were isotopically heavy from input 
thermal-water effluent from the Turkey Run Mine. The creek water became isotopically lighter towards the confluence of the East and West Forks of Harley Gulch at sample site HG4 as it mixed with meteoric water (fig. 27). Then waters became isotopically heavier downstream from site HG4 reaching a maximum value at site HG7 as the connate groundwater input increased in this segment of the creek (fig. 27). Downstream from site HG7, waters became isotopically lighter as meteoric water increased in the segment of the creek to sample site HG10. During the low-flow sampling event in May 2011, waters were heaviest in the middle of the wetlands at sample site HG1.5, and waters were light downstream from the confluence in Harley Gulch, indicating that meteoric water dominated downstream water chemistry. Waters collected during the high-flow sampling event of March 2011 were isotopically light, with all samples plotting above the GMWL (fig. 26). These samples were collected during a major storm, during which flow rates in Harley Gulch were at an annual peak. Waters collected during the high-flow sampling event of June 2011 were influenced by connate groundwater input, plotting below the GMWL, with the isotopically heaviest water occurring at sample site HG2, downstream from the wetlands (fig. 26), indicating that connate groundwater was actively entering the creek in the central part of the wetlands in the area of site HG1.5. Waters collected in the East Fork of Harley Gulch at sample site HG3 typically were among the lightest isotopically in the watershed for all sampling events, and they reflect the dominance of meteoric water and the lower amounts of connate groundwater in this section of the watershed. These patterns suggest two main inputs of isotopically-heavy connate groundwater-one in the middle of the wetland area, and a second area farther downstream between sample site HG4 to HG7.

The composition of waters in Harley Gulch reflect the three end-member water sources, and the contribution of each can be calculated based on the isotopic and chemical composition of each source. For the meteoric water source, the isotopic and chemical composition of surface water in a nearby watershed, the Fresh Water Branch of Sulphur Creek, was used. This watershed does not contain thermal or connate groundwater. The isotopic and chemical composition of the thermal-water source is from waters sampled at the Turkey Run adit. For the connate groundwater source, the isotopic and chemical composition of Harley Gulch creek water at sample site HG7 was used. However, in 2011, the hydrology of the watershed had changed such that the isotopically heaviest connate groundwater emanated at site HG1.5, and the water chemistry at this site was used for the connate-groundwater source for the 2011 sampling events. The percentage of thermal-water and connate-groundwater source contribution to Harley Gulch stream water was calculated using data from thermal-water effluent sampled in 1997 and connate-groundwater sampled in 2010 and 2011. These calculations are listed in table 8.

The calculations of water composition demonstrate the dominance of each source of fluid to Harley Gulch based on flow conditions and seasonality. During the low-flow sampling event in June 2010, mine effluent was dominant in the upper section of the West Fork of Harley Gulch, and the connate-groundwater source near sample site HG7 also contributed significantly to stream chemistry. During the low-flow sampling event in May 2011, mine-effluent was less of a contributor to stream chemistry, and connate-groundwater from the springs in the wetlands near site HG1.5 was dominant. Under high-flow conditions in both March and June 2011, meteoric water was more dominant, with only minor signals of mine-effluent and connate-groundwater influence. In the East Fork of Harley Gulch at sample site HG3, connate groundwater is a significant component of the creek water under low-flow conditions, but it decreased to about 20 percent under high-flow conditions because meteoric water diluted the groundwater source (table 8). The difference in isotopic composition of waters collected at sample site HG3 in the East 
Fork during two low-flow sampling events in June 2010 and May 2011 indicates the complexity of water sources to Harley Gulch and suggests that evaporation may contribute to isotopic composition of stream waters.

\section{Biogenic Sediment}

Biogenic sediment accumulates in the upper part of Harley Gulch between sample sites HG2 and HG10 during the dry seasons. The biogenic sediment covers the creek bed with a tan 1-2 cm thick layer of sediment that consists of living and recently expired diatoms (figs. 28 and 29). Below this surface layer, the biogenic sediment has a black color owing tothe presence of iron sulfide (FeS) (figs. 12 and 30). The black biogenic sediment consists of diatom fragments and minor amounts of clay and bioclastic carbonate grains. X-ray diffraction of the biogenic sediment shows that a silica phase is the primary component of the sediment, and it indicates that silica shells of diatoms are the primary component of the sediment. During the low-flow conditions in the dry season, particulate transport is minimal and the diatoms accumulate essentially in place. The thickness of the biogenic sediment is variable, with deep pools in the creek containing up to several tens of centimeters of sediment. In seasonally dry segments of the creek, the biogenic sediment is light gray and has the consistency of diatomite (fig. 31). The concentration of $\mathrm{Hg}$ in the biogenic sediment typically is high and ranges from 0.39 to $50.3 \mu \mathrm{g} / \mathrm{g}$ (table 4). The highest $\mathrm{Hg}$ concentrations in biogenic sediment occur upstream from, and at site HG4, and decrease systematically downstream to site HG9.5 (in between sites HG9 and HG10).

Several types of diatoms occur in the biogenic sediment (fig. 32) and the species that predominate change in differenct segments of the creek. At sample site HG6 a diverse assemblage of Nitzschia species and a number of Rhopalodia are present. These benthic species prefer neutral to alkaline $\mathrm{pH}$ and can tolerate backish water. At sample site HG7 the most common species is Mastogloia smithii, but a number of other species are also present. The abundance of a number of diatom species likely reflects the high carbonate and chloride concentration of the water but the presence of species more typically found in deeper water is unusual.

\section{Carbonates}

The biogenic sediment contains variable amounts of calcite $\left(\mathrm{CaCO}_{3}\right)$ that occurs as aggregates and individual grains. The waters in the upper part of Harley Gulch have high alkalinity and $\mathrm{Ca}$ content (table 3 ). Calcite precipitates in the creek water when oversaturation occurs, with respect to $\mathrm{Ca}$ and $\mathrm{CO}_{3}$, as the creek water evaporates during the dry season.

\section{Sulfides}

Micron to submicron grains of $\mathrm{HgS}$ occur in the biogenic sediment as individual grains and aggregates in association with the diatoms in the black biogenic sediment. Scanning electron microscopy (SEM) has documented the presence of HgS grains, and EDAX (Energy Dispersive Spectroscopy) has demonstrated that $\mathrm{Hg}$ and $\mathrm{S}$ are the only two elements in the phase (fig. 33). The HgS typically occurs as aggregates of framboids amidst fragments of diatom shells (fig. 34). Submicron grains of FeS are the most abundant sulfide visible under the SEM, and they occur as aggregates and individual grains in association with the fragments of diatom shells (fig. 35). EDAX spectra confirm that the FeS grains contain only Fe and S. 


\section{Sulfates}

Barite, barium sulfate $\left(\mathrm{BaSO}_{4}\right)$, forming hexagonal-appearing crystals and aggregates of acicular crystals, is common in the biogenic sediment (fig. 36). Barite spheres with dissolution pits also have been observed. Microbially mediated precipitation of barite results in crystal forms other than the more typical orthorhombic tabular crystals (Bonny and Jones, 2008). The Ba and $\mathrm{SO}_{4}$ concentrations of creek water in the upper part of Harley Gulch are high because of the input of connate groundwater in this segment of the creek. The exact mechanism of barite precipitation in Harley Gulch waters is unknown. However, it is likely that the precipitation of barite is mediated by bacteria (Baldi et al, 1996; Bonny and Jones, 2008; González and others, 2003; Senko and others, 2004), and that the sulfate-reducing bacteria present in Harley Gulch are involved in the precipitation and dissolution of batire. Less commonly, a magnesium-sulfate phase, likely epsomite, occurs in the dry biogenic sediment (fig. 37). The precipitation of this phase reflects the high $\mathrm{Mg}$ and sulfate concentrations that occur in the creek water, which becomes concentrated as portions of the creek cease to flow and dry completely in the summer months.

\section{Oxides}

Less common phases in the black biogenic sediment include a tungsten (W) oxide and a titanium (Ti) oxide phase. Both $\mathrm{W}$ and Ti concentrations are elevated in the connate groundwater that occurs in the upper part of Harley Gulch, and this likely causes the precipitation of the $\mathrm{W}$ and Ti phases (fig. 39).

\section{Invertebrates}

Composite samples of aquatic invertebrates were collected from 13 sites in 2008, from 16 sites in 2010, and from 7 sites in 2011 for comparison with samples analyzed in 2002 and 2007 at Harley Gulch. Invertebrates that might be consumed by frogs were also collected. Based on food habits analyses, two of the 15 frogs from 2007 and one of the 7 frogs from 2008 had consumed water striders; three frogs from 2007 had consumed damselflies.

Trends similar to those observed in 2007 were evident in the 2008, 2010, and 2011 samples. Concentrations of $\mathrm{MMeHg}$ in invertebrates appear to decrease with increasing distance from the Abbott-Turkey Run $\mathrm{Hg}$ mines, with the exception of the predaceous diving beetles (fig. 40), which were highly variable. Concentrations of $\mathrm{MMeHg}$ in water striders and larval dragonflies collected in 2007 were higher than in similar taxa collected from similar sites in 2008, 2010, and 2011. However, samples collected at comparable sites in 2011, while mostly lower in $\mathrm{MMeHg}$ than 2007 samples, generally were higher in $\mathrm{MMeHg}$ than samples from 2008 and 2010 (figs. 40-44).

Concentrations observed in samples collected from the East Fork site (HG3) were considered background values because the site is above contamination from the Abbott-Turkey Run mines. In 2008, however, the highest MMeHg concentration found in Harley Gulch was found in Belostomatidae from HG3 $(1.71 \mu \mathrm{g} / \mathrm{g}$ ) (table 9). These predatory insects feed on aquatic insects, as well as frogs (Benard, 2007) and small fish, and it is common for them to bioaccumulate high concentrations of $\mathrm{MMeHg}$ (Alpers and others, 2005). Another Belostomatid collected from HG5 had the second highest concentration of MMeHg in $2008(1.45 \mu \mathrm{g} / \mathrm{g})$ (table 9). The lowest MMeHg concentration in 2008 was found in damselflies (Lestidae) from the most downstream site in the watershed, HG14 $(0.0039 \mu \mathrm{g} / \mathrm{g})$ (table 9, fig. 43). In 2010, the highest 
MMeHg concentration was found in Dytiscidae from HG6 (0.235 $\mu \mathrm{g} / \mathrm{g})$ (fig. 40), and the lowest concentration was found in Lestidae from HG14 (0.0029 $\mu \mathrm{g} / \mathrm{g}$ ) (fig. 43). In 2011, fewer sites, all located in the upper part of Harley Gulch, were sampled (fig. 2). The sample with the highest concentration of MMeHg was Coenagrionidae from site HG2 in the wetlands $(0.604 \mu \mathrm{g} / \mathrm{g})$. That sample also had a high concentration of $\mathrm{Hg}_{\mathrm{T}}(4.5 \mu \mathrm{g} / \mathrm{g})$, but the percentage of $\mathrm{MMeHg}$ was only 13.4. The samples with the five highest concentrations of $\mathrm{Hg}_{\mathrm{T}}$ in 2011 were from wetlands sites (HG1 and HG2: 1.24-9.94 $\mu \mathrm{g} / \mathrm{g}$ ) (fig. 45). The samples with five of the seven highest MMeHg concentrations also were from sites HG1 and HG2 $(0.228-0.604 \mu \mathrm{g} / \mathrm{g})$;however, six of the nine samples with the lowest MMeHg: $\mathrm{Hg}_{\mathrm{T}}$ ratios were from the two wetlands sites. At HG1, the percentage of $\mathrm{MMeHg}$ in the three collected samples ranged from 1.90 to 2.61. For comparison, all samples from $\mathrm{HG} 3$, the reference site, had $>30$ percent $\mathrm{MMeHg}$ (fig. 46). Total $\mathrm{Hg}$ concentrations for taxa collected from the wetlands sites (HG1, HG2, and HG2a) increased from 2010 to 2011, but the percentage MMeHg tended not to change (fig. 45). During 2007-2011, the percentage $\mathrm{MMeHg}$ declined for water striders (Gerridae) and dragonflies (Libellulidae) at the reference site (HG3) as well as at downstream sites (HG4, HG5, HG6, and HG7), apparently in relation to availability of the $\mathrm{HgT}$ and $\mathrm{MMeHg}$ in the system those years (fig. 46).

Slotton and others (2004) collected invertebrates from the Cache Creek watershed and found that $\mathrm{MMeHg}$ was present at higher concentrations in aquatic invertebrates from Harley Gulch than at any other site sampled in the watershed. Samples of damselflies (Coenagrionidae), dobsonflies (Corydalidae), net-spinning caddisflies (Hydropsychidae), and creeping water bugs (Naucoridae) were collected on May 8, 2000, 13-27 days earlier than the 2008 collections. Those samples had average MMeHg concentrations of $0.296,0.582,0.274$, and $0.937 \mu \mathrm{g} / \mathrm{g}$, respectively, for the four taxa. Although the taxa were not identical, the mean concentrations of $\mathrm{MMeHg}$ in the invertebrates collected in 2002 were higher, those collected in 2007 were similar, and those collected in 2008, 2010, and 2011 were generally lower than those collected by Slotton and others (2004).

\section{Frogs}

On May 16, 2007, two foothill yellow-legged frogs were collected from the East Fork (HG3) and 13 more were collected from four lower Harley Gulch sites (HG4 through HG7). On June 4, 2008, seven yellow-legged frogs were collected from lower Harley Gulch (one each from HG5, HG9, HG10, HG11, and HG13, and two from HG8) (table 10).

Adult frog sizes within and between 2007 and 2008 were compared. There were no differences between genders for mass $(\mathrm{H}=0.102 ; \mathrm{P}=0.805)$ or $\mathrm{SVL}(\mathrm{F}=1.064 ; \mathrm{P}=0.323)$ in 2007 or in 2008 for mass $(\mathrm{F}=1.187 ; \mathrm{P}=0.326)$ or SVL $(\mathrm{F}=1.605 ; \mathrm{P}=0.261)$. In addition, neither the mass nor the SVL for either the males or the females differed by year $(\mathrm{P}>0.23)$. Although the mean mass $(10.54 \mathrm{~g})$ and the mean SVL $(45.77 \mathrm{~mm})$ of the females from both years combined were greater than the mean mass $(7.71 \mathrm{~g})$ and SVL $(39.45 \mathrm{~mm})$ of the males, neither difference was significant $(\mathrm{H}=1.269 ; \mathrm{P}=0.260$ and $\mathrm{F}=2.504 ; \mathrm{P}=0.130$, respectively). The correlation between SVL and body mass $\left(\mathrm{R}^{2}=0.947\right)$ for all 21 of the Harley Gulch frogs collected in 2007 and 2008 was significant $(\mathrm{F}=359.3 ; \mathrm{P}<0.001)$.

Neither the correlation between SVL and $\mathrm{Hg}_{\mathrm{T}}$ in frogs from 2007 ( $\left.\mathrm{F}=1.84 ; \mathrm{P}=0.202\right)$ nor between SVL and MMeHg in frogs from $2008(\mathrm{~F}=2.716 ; \mathrm{P}=0.160)$ was significant. There was no significant correlation between body mass and $\mathrm{Hg}_{\mathrm{T}}$ in frogs collected from Harley Gulch in 2007 $(\mathrm{F}=1.33 ; \mathrm{P}=0.274)$, or between mass and $\mathrm{MMeHg}$ in frogs collected in 2008 ( $\mathrm{F}=3.084 ; \mathrm{P}=0.139)$. There was no significant difference between geometric mean $\mathrm{Hg}_{\mathrm{T}}$ concentrations in males $(0.800$ 
$\mu \mathrm{g} / \mathrm{g})$ and females $(0.830 \mu \mathrm{g} / \mathrm{g})(\mathrm{F}=0.034 ; \mathrm{P}=0.856)$ from lower Harley Gulch collected in 2007, nor between $\mathrm{MMeHg}$ concentrations in males $(0.365 \mu \mathrm{g} / \mathrm{g})$ and females $(0.255 \mu \mathrm{g} / \mathrm{g})(\mathrm{F}=0.958$; $\mathrm{P}=0.373$ ) collected in 2008. These low correlations between size and gender and $\mathrm{Hg}$ concentration in frogs from Harley Gulch, indicate that the differences in $\mathrm{Hg}_{\mathrm{T}}$ and $\mathrm{MMeHg}$ concentrations are related to site differences in $\mathrm{Hg}$ contamination.

Geometric-mean concentrations of $\mathrm{Hg}_{\mathrm{T}}$ in frogs collected from four lower Harley Gulch sites in 2007 (table 10) were not significantly different from one another $(\mathrm{F}=0.238 ; \mathrm{P}=0.868)$, or from frogs collected from Harley Gulch in 1997 (table 11; fig. 47). All lower Harley Gulch frogs collected in 2007 had significantly higher geometric-mean concentrations of $\mathrm{Hg}_{\mathrm{T}}$ than did the three reference sites (table 11) and the East Fork of Harley Gulch site (HG3) (fig. 47). In 2008, all frogs were collected from below the confluence of the two forks of Harley Gulch and were analyzed for $\mathrm{MMeHg}$ only. $\mathrm{MMeHg}$ concentrations ranged from $0.135 \mu \mathrm{g} / \mathrm{g}$ to $0.468 \mu \mathrm{g} / \mathrm{g}$, with the highest concentration found in the frog from HG5. To compare Hg concentration in 2008 with previous years, $\mathrm{Hg}_{\mathrm{T}}$ concentrations in 2008 were estimated based on the percentage $\mathrm{MMeHg}$ in frogs analyzed for both $\mathrm{Hg}_{\mathrm{T}}$ and $\mathrm{MMeHg}$ in 2007 (see statistics section). Estimated $\mathrm{Hg}_{\mathrm{T}}$ values found in frogs from sites HG5 and HG8 in 2008 were comparable to values found in frogs from nearby sites (HG4-HG7) in 2007 (fig. 48). However, as was found for the invertebrates, the concentrations of $\mathrm{MMeHg}$ in frogs tended to decrease going downstream (fig. 49). The MMeHg concentration in the frog from site HG5 $(0.468 \mu \mathrm{g} / \mathrm{g})$ was about 3 times higher than the concentration of $\mathrm{MMeHg}$ in the frog collected about 5,000 $\mathrm{m}$ further downstream at site HG13 $(0.152 \mu \mathrm{g} / \mathrm{g})$. Based on linear regression analysis, there was a significant decrease in $\mathrm{MMeHg}$ concentration in foothill yellow-legged frogs with distance from the mines $\left(\mathrm{R}^{2}=0.708\right.$; $\mathrm{P}=0.036)$.

For comparison, the overall mean $\mathrm{Hg}_{\mathrm{T}}$ concentration for the lower Harley Gulch frogs in $2007(0.814 \mu \mathrm{g} / \mathrm{g})$ was similar to the mean observed for leg muscle in pig frogs (Rana grylio) $(0.911 \mu \mathrm{g} / \mathrm{g})$ from a highly contaminated site in the Florida Everglades (Ugarte and others, 2005). The estimated mean $\mathrm{Hg}_{\mathrm{T}}$ of the three frogs collected in the same general area of lower Harley Gulch was $0.902 \mu \mathrm{g} / \mathrm{g}$, a value similar to both the 2007 mean and the mean from the Everglades.

Based on the mean $\mathrm{Hg}_{\mathrm{T}}$ concentration in the frogs from East Fork of Harley Gulch in 2007, there do not appear to be significant sources of $\mathrm{Hg}$ contamination east of the confluence of the two forks. The Abbott-Turkey Run Hg mines upstream of the West Fork of Harley Gulch (fig. 1) appear to be important sources of mercury to the West Fork and further downstream in Harley Gulch.

$\mathrm{The}^{\mathrm{Hg}_{\mathrm{T}}}$ concentration in 31 percent of the 13 frogs collected from lower Harley Gulch in 2007 exceeded the FDA criterion $(1.0 \mu \mathrm{g} / \mathrm{g})$ for regulation of commercial fish (U.S. Food and Drug Administration, 2001), while none of the seven frogs collected in 2008 exceeded that criterion. In addition, the Hg concentrations in 100 percent of the 2007 frogs and 43 percent of the 2008 frogs exceeded the USEPA Hg criterion $(0.3 \mu \mathrm{g} / \mathrm{g})$ for issuance of health advisories for human fish consumption (U.S. Environmental Protection Agency, 2001). $\mathrm{The}^{\mathrm{Hg}_{\mathrm{T}}}$ in the 13 frogs collected in 2007, the estimated $\mathrm{Hg}_{\mathrm{T}}$ in the seven frogs collected in 2008, and the $\mathrm{Hg}_{\mathrm{T}}$ in the frogs collected from Harley Gulch in 1997-1998 all exceeded the Hg criterion for the protection of piscivorous wildlife $(0.077 \mu \mathrm{g} / \mathrm{g}$ : the no-effect level) (U.S. Environmental Protection Agency, 1997). Therefore, $\mathrm{Hg}$ concentrations in foothill yellow-legged frogs from all years were high enough to pose a potential hazard to their predators. 


\section{Fish}

Seven fish were collected from site HG8a in Harley Gulch (table 12, fig. 16). $\mathrm{Hg}_{\mathrm{T}}$ concentrations in fish ranged from $0.264 \mu \mathrm{g} / \mathrm{g}$, ww to $0.414 \mu \mathrm{g} / \mathrm{g}$, ww. MMeHg in fish ranged from $0.173 \mu \mathrm{g} / \mathrm{g}$, ww to $0.356 \mu \mathrm{g} / \mathrm{g}$, ww. Percent MMeHg in fish ranged from 65 percent to 125 percent.

\section{Conclusions}

Concentrations of MMeHg in water exceed the Harley Gulch TMDL aqueous annual median concentration of $0.09 \mathrm{ng} / \mathrm{L}$ at all sample sites and flow conditions, except in the East Fork of Harley Gulch (HG3). High aqueous concentrations of MMeHg were measured under both high and low conditions, and the highest concentrations occurred in the West Fork of Harley Gulch downstream from the mine. Under high-flow conditions at site HG1 in March 2011, the aqueous $\mathrm{MMeHg}$ concentration was the highest measured (15.8 $\mathrm{ng} / \mathrm{L})$ indicating export of $\mathrm{MMeHg}$ from the mine. Under low-flow conditions in June 2010 at site HG2 downstream from the wetland the $\mathrm{MMeHg}$ aqueous concentration also was high $(12.1 \mathrm{ng} / \mathrm{L})$ indicating export of $\mathrm{MMeHg}$ from the wetland area. During the low-flow conditions in June 2010, the input of connate groundwater between sample sites HG4 and HG7 correlated with an increase in aqueous $\mathrm{MMeHg}$ concentration in that segment of the creek, despite a corresponding decrease in $\mathrm{Hg}_{\mathrm{T}}$ in the creek segment. The data indicate that connate groundwater contributes to $\mathrm{MMeHg}$ production in the upper part of Harley Gulch between sites HG4 and HG7. However, at the entry area of groundwater to the wetland at site $\mathrm{HG} 1.5$, aqueous $\mathrm{MMeHg}$ is low despite very high filtered and $\mathrm{Hg}_{\mathrm{T}}$ concentrations, indicating that several factors, other than just connate groundwater input, play an important role in the methylation of $\mathrm{Hg}$ in Harley Gulch.

$\mathrm{MMeHg}$ levels in active stream-channel sediment in Harley Gulch show a complex pattern. MMeHg levels in sediment are low at sample site HG1, immediately downstream from the mine, and increase to elevated levels in the middle of the wetland area (sample site HG1.5 and immediately downstream at sample site HG2). The wetland environment is, therefore, favorable for the methylation of $\mathrm{Hg}$. The systematic increase in $\mathrm{MMeHg}$ concentration in sediments from sample sites HG5 to HG7 (June 2010 sampling event) corresponds to the input of connate groundwater in this segment of the creek. Thus, the connate groundwater contributes to $\mathrm{MMeHg}$ production. However, the high concentrations of $\mathrm{MMeHg}$ in sediments collected in Harley Gulch are largely caused by the unusual abundance of diatoms in the biogenic sediment that occurs between sample sites HG2 and HG 9.5. Because the diatoms in the biogenic sediment bioaccumulate $\mathrm{Hg}$ and $\mathrm{MMeHg}$, the concentrations of $\mathrm{Hg}$ and $\mathrm{MMeHg}$ in the biogenic sediment are much higher than in clastic sediment.

Phytoplankton are important in the $\mathrm{Hg}$ cycle because they are the entry point of $\mathrm{Hg}$ and $\mathrm{MMeHg}$ into the food web (fig. 50). The bioaccumulation factor between phytoplankton and water is the highest for any of the $\mathrm{Hg}$ and $\mathrm{MMeHg}$ trophic transfers. Bioaccumulation factors between phytoplankton and water are highly variable and can range from 26,000 to 50,000 for $\mathrm{Hg}$, and 19,000 to 1,460,000 for MMeHg (Kuwabara and others, 2005; Pickhardt and Fisher, 2007). As a result, phytoplankton, such as diatoms, can have high concentrations of $\mathrm{Hg}$ and $\mathrm{MMeHg}$. In the upper part of Harley Gulch where connate groundwater with high concentrations of $\mathrm{Hg}$ enters the creek, the creek water has high concentrations of $\mathrm{Hg}$ and this results in high bioaccumulation of $\mathrm{Hg}$ and $\mathrm{MMeHg}$ in the diatoms 
The bioaccumulation factor between phytoplankton in the biogenic sediment in Harley Gulch and total $\mathrm{Hg}\left(\mathrm{Hg}_{\mathrm{T}}\right)$ and filtered $\mathrm{Hg}\left(\mathrm{Hg}_{\mathrm{F}}\right)$ in water is high: 37,500 for $\mathrm{Hg}_{\mathrm{T}}$ and 60,000 for $\mathrm{Hg}_{\mathrm{F}}$ (fig. 51). The linear relationship between both $\mathrm{Hg}_{\mathrm{T}}$ and $\mathrm{Hg}_{\mathrm{F}}$ in water and the concentration of $\mathrm{Hg}$ in the biogenic sediment demonstrates a positive relationship between $\mathrm{Hg}$ concentration in streamwater and $\mathrm{Hg}$ concentration in the diatoms in the biogenic sediment. Based on this relationship and association of $\mathrm{HgS}$ with the reduced black biogenic sediment, a two-step model for the formation of $\mathrm{Hg}$ enriched biogenic sediment is proposed (fig. 52). In the first step, $\mathrm{Hg}$ and $\mathrm{MMeHg}$ are bioaccumulated in living diatoms. Because the concentration of $\mathrm{Hg}$ in the connate groundwater in the upper part of Harley Gulch is elevated, the diatoms initially have a high concentration of $\mathrm{Hg}$ and $\mathrm{MMeHg}$. In the second step of the process, the expired diatoms release $\mathrm{Hg}$ and $\mathrm{MMeHg}$ to pore fluids of the biogenic sediment. Because the creek water has high $\mathrm{SO}_{4}$ and $\mathrm{Fe}$ concentrations, $\mathrm{SO}_{4}$-reducing bacteria reduce $\mathrm{SO}_{4}$ to sulfide which then reacts with the $\mathrm{Hg}$ in the pore fluids to precipitate submicron-size grains of $\mathrm{HgS}$. The $\mathrm{Fe}$ in the pore fluids also reacts with the sulfide, and precipitates as FeS, which gives the sediment its black color. High barium and sulfate concentrations in the pore waters result in microbially mediated precipitation of unusual crystal forms of barite, though the exact mechanism of this precipitation is not completely understood. The high concentration of $\mathrm{W}$ and $\mathrm{Ti}$ in the pore fluid leads to precipitation of $\mathrm{W}$ and $\mathrm{Ti}$ oxide phases. The resulting biogenic sediment is enriched in $\mathrm{HgS}, \mathrm{FeS}$, barite, $\mathrm{W}$, and Ti oxides. The biogenic sediment also has extremely high MMeHg concentrations ranging from 11.1 to $36.3 \mathrm{ng} / \mathrm{g}$ because of the high bioaccumulation factor for $\mathrm{MMeHg}$ between water and diatoms. This natural $\mathrm{Hg}$ and $\mathrm{MMeHg}$ trap has not been previously documented, and it is a continuing source of $\mathrm{Hg}$ - and $\mathrm{MMeHg}$-enriched material in sediment in Harley Gulch. The biogenic sediment is very fine grained and is transported downstream to the Harley Gulch delta and into Cache Creek during the first high-flow events in the early part of the winter wet season. The relative magnitude of $\mathrm{Hg}$ and $\mathrm{MMeHg}$ released to Harley Gulch from this natural biogenic source as compared to the mining source needs to be documented further. However, the concentrations of $\mathrm{Hg}$ in waters sampled during high-flow events and in storm sediment bring significant amounts of $\mathrm{Hg}$ into Harley Gulch from the Abbott-Turkey Run mine 4 years after clean up.

$\mathrm{MMeHg}$ levels in biota are highest immediately downstream from the mine at site HG1. The high levels of $\mathrm{Hg}_{\mathrm{T}}$ and $\mathrm{MMeHg}$ in biota at site $\mathrm{HG} 1$ correlate with high levels of $\mathrm{Hg}$ and $\mathrm{MMeHg}$ in water from the mine areaconsisting of meteoric runoff and release of thermal water. Below site $\mathrm{HG}$, levels of $\mathrm{Hg}_{\mathrm{T}}$ and $\mathrm{MMeHg}$ remain elevated in all trophic levels downstream to site HG7. Connate groundwater with elevated concentrations of $\mathrm{Hg}$ and biogenic sediment enriched in $\mathrm{Hg}$ and $\mathrm{MMeHg}$ are present and contribute to the elevated levels of $\mathrm{Hg}_{\mathrm{T}}$ and $\mathrm{MMeHg}$ in biota in this segment.

The source of $\mathrm{Hg}_{\mathrm{T}}$ and $\mathrm{MMeHg}$ in biota probably is not only the Abbott-Turkey Run mine, but also connate groundwater and biogenic sediment present in Harley Gulch. These natural sources of $\mathrm{Hg}$ and $\mathrm{MMeHg}$ in the upper part of Harley Gulch significantly contribute to uptake of $\mathrm{Hg}$ and $\mathrm{MMeHg}$ by biota. If release of $\mathrm{Hg}$ and $\mathrm{MMeHg}$ from the mine can be controlled in the future with further remediation, the natural sources will still contribute to elevated levels of $\mathrm{Hg}$ and $\mathrm{MMeHg}$ in biota. Presently, both natural and mining sources of $\mathrm{Hg}$ and $\mathrm{MMeHg}$ continue to impact biota in Harley Gulch. 


\section{Acknowledgments}

We wish to acknowledge the USBLM for providing funding for this work. Laura Young assisted with field work in 2011 and helped prepare the figures. Darrin Bergen provided field assistance in 2007. Previous versions of this report were improved by suggestions from Roger Ashley, Steve Ludington, James Weigand, and Janet Whitlock. Biological samples were collected under a scientific collecting permit issued by the State of California, Department of Fish and Game.

\section{References Cited}

Alpers, C.N., M.P. Hunerlach, J.T. May, R.L. Hothem, H.E. Taylor, R.C. Antweiler, J.F. DeWild, and D.A. Lawler. 2005. Geochemical characterization of water, sediment, and biota affected by mercury contamination and acidic drainage from historical gold mining, Greenhorn Creek, Nevada County, California, 1999-2001. U.S. Geological Survey, Scientific Investigations Report 2004-5251, 278 pp.

Baldi, F., Pepi, M., Burrini, D., Kniewald, G., Scali, D., and Lanciotti, E., 1996, Dissolution of barium from barite in sewage sludges and cultures of Desulfobibrio desulfuricans: Applied and Environmental Microbiology, v. 62, p. 2398-2404.

Benard, M.F., 2007, Predators and mates - conflicting selection on the size of male Pacific treefrogs (Pseudacris regilla): Journal of Herpetology, v. 41, p. 317-320.

Bloom, N.S., 1989, Determination of picogram levels of methylmercury by aqueous phase ethylation, followed by cryogenic gas chromatography with cold vapour atomic fluorescence detection: Canadian Journal of Fisheries and Aquatic Sciences, v. 46, p. 1131-1140.

Bloom, N.S., 1995, Mercury as a case study of ultra-clean sample handling and storage in aquatic trace metal research: Environmental Laboratory, v. 3-4, p. 20-25.

Bloom, N.S., Crecelius, E.A., and Fitzgerald, W.F., 1988, Determination of volatile mercury species at the picogram level by low temperature gas chromatography with cold vapor atomic fluorescence detection: Analytica Chimica Acta, v. 208, p. 151-161.

Bonny, S.M., and Jones, B., 2008, Experimental precipitation of barite among streamers of sulphur-oxidizing bacteria: Journal of Sedimentary Research, v. 78, p. 357-365.

Central Valley Regional Water Quality Control Board. 2003. 2003 CWA section 303(d) list of water quality limited segment, accessed 9/17/11 at www.watercoards.ca.gov/water issues/programs/tmdl/integrated2010.shtml.

Churchill, R., and Clinkenbeard, J., 2003, Assessment of the feasibility of remediation of mercury mine sources in the Cache Creek watershed-CALFED final report and appendices, accessed $9 / 17 / 11$ at http://loer.tamug.tamu.edi/calfed/Report/Final/Calfed_Mercury_Final_Report_Task5C1 _091503.pdf.

Cooke, A.S. 1981. Tadpoles as indicators of harmful levels of pollution in the field: Environmental Pollution (Serial A), v. 25, p. 123-133.

Coplen, T. B., 1994. Reporting of Stable Hydrogen, Carbon, and Oxygen Isotopic Abundances, Pure and Applied Chemistry, v. 66, p. 273-276.

Coplen, T. B., Wildman, J. D. and Chen, J., 1991. Improvements in the Gaseous HydrogenWater Equilibration Technique for Hydrogen Isotope Ratio Analysis, Analytical Chemistry, v. 63, p. 910-912. 
Crock, J.G., 1996, Mercury_Chapter 29 in Sparks, D.L., ed., Methods of soil analysis, part 3, chemical methods: Soil Science Society of America Book Series, no. 5, p. 769-791.

Domagalski, J., 2001, Mercury and methylmercury in water and sediment of the Sacramento River Basin, Ca: Applied Geochemistry, v. 16, p. 1677-1691.

Domagalski, J.L., Alpers, C.N., Slotton, D.G., Suchanek, T.H., and Ayers, S.M., 2004,Mercury and methylmercury concentrations and loads in the Cache Creek watershed, California: Science of the Total Environment, v. 327, p. 215-237.

Donnelly-Nolan, J.M., Burns, M.G., Goff, F.E., Peters, E.K., and Thompson, J.M., 1993, The Geysers-Clear Lake area, CA-Thermal waters, mineralization, volcanism, and geothermal potential: Economic Geology, v. 88, p. 301-316.

Epstein, S. and Mayeda, T., 1953. Variation of O-18 content of water from natural sources. Geochim. Cosmochim. Acta, v. 4, p. 213-224.

Foe, C.G., and Croyle, B., 1998, Mercury concentration and loads from the Sacramento River and from Cache Creek to the Sacramento-San Joaquin Delta Estuary: Staff report, California Regional Water Quality Control Board, Central Valley Region, Sacramento, Calif. 81 p., 2 appendices.

Foe, C. and Bosworth, D., 2008, Mercury inventory in the Cache Creek Canyon: California Environmental Protection Agency, Regional Water Quality Control Board, Central Valley Region, 48 p.

Fishman, M.J. and Pyen, G., 1979, Determination of selected anions in water by ion chromatography: U.S. Geological Survey Water Resources Investigations 79-101, 30 p.

Gill, G.A., and Fitzgerald, W.F., 1987, Picomolar mercury measurements in seawater and other materials using stannous chloride reduction and two-stage gold amalgamation with gas phase detection: Marine Chemistry, v. 20, p. 227-243.

Goff, F., and Janik, C.J., 1993, Gas geochemistry and guide for geothermal features in the Clear Lake region, California, in Rytuba, J. J. ed., Active geothermal systems and goldmercury deposits in the Sonoma-Clear Lake volcanic fields: California, Society of Economic Geologists Guidebook 16, p. 207-261.

González-Muñoz, M.T., Fernández-Luque, B., Martínez-Ruiz, F., Chekroun, K.B., Arias, J.M., Rodríguez-Ballego, M., Martínez-Cañamero, M., De Linares, C., and Paytan, A., 2003, Precipitation of barite by Myxococcus Xanthus - possible implications for the biogeochemical cycle of barium: Applied and Environmental Microbiology, v. 69, p. 5722-5725.

Holloway, J.M., Goldhaber, M.B., and Morrison, J.M., 2009, Geomorphic controls on mercury accumulation in soils from a historically mined watershed, Central California Coast Range, USA: Applied Geochemistry, v. 24, p. 1538-1548.

Horita, J., Wesolowski, D., and Cole, D., 1993. The activitycomposition relationship of oxygen and hydrogen isotopes in aqueous salt solutions: I. Vapor-liquid water equilibration of single salt solutions from 50 to $100 \varnothing$ C, Geochim. Cosmochim. Acta, v. 57, p. 2797-2817.

Horvat, M., Bloom, N.S., and Liang, L., 1993, Comparison of distillation with other current isolation methods for the determination of methyl mercury compounds in low level environmental samples, part 1 sediments: Analytica Chimica Acta, v. 281, p. 135-152.

Hothem, R.L., M.R. Jennings, and J.J. Crayon. 2010. Mercury contamination in three species of Anuran amphibians from the Cache Creek Watershed, California, USA: Environmental Monitoring and Assessment, v. 163 p. 433-448. 
Ichikawa, G., and Jakl, B., 2004, Data and quality assurance/quality control report for Harley Gulch maximum daily load (TMDL) project: Prepared for Water Quality Control Board, Central Valley Region, Sacramento, Calif., 20 p.

Kendall, C. and Coplen, T.B., 1985. Multisample Conversion of Water to Hydrogen by Zinc for Stable Isotope Determination. Anal. Chem. v. 57, p. 1437-1440.

Kim, C.S., Brown Jr., G.E., and Rytuba, J.J., 2004, Geological and anthropogenic factors influencing mercury speciation in mine wastes - an EXAFS spectroscopy study: Applied Geochemistry, v. 19, no. 3, p. 379-393.

Kuwabara, J.S., Topping, B.R., and others, 2005, Mercury accumulation by lower trophic-level organisms in lentic systems within the Guadalupe River Watershed, California: U.S. Geological Survey Scientific Investigations Report 2005-5037, 59 p.

Larson, E., 2007, Abbott, Turkey Run mine cleanup project completed: Lake County News, accessed 9/28/11 at http://lakeconews.com/content/view/1715/919/.

Moisseeff, A.N., 1966, The geology and geochemistry of the Wilbur Springs quicksilver district, Colusa and Lake counties, California: Stanford University, unpublished $\mathrm{Ph} . \mathrm{D}$. dissertation, $214 \mathrm{p}$.

National Research Council of Canada Institute for National Measurement Standards, 1999, DORM-2, DOLT-2, Dogfish muscle and liver certified reference materials for trace metals: INMS Certified Reference Materials Data Sheet, 4 p. (Also available at http://www.ems.nrc.ca/ems1.htm, last accessed January 28, 2009.)

O'Leary, R.M., Hageman, P.L., and Crock, J.G., 1996, Determination of mercury in water, geologic, and plant materials by continuous flow-cold vapor-atomic absorption spectrophotometry, in Arbogast, B.F., ed., Quality assurance manual for the branch of geochemistry-United States Geological Survey: United States Geological Survey OpenFile Report 96-525, p. 42-55.

Orion Research, Inc., 1978, Analytical methods guide, 9th ed.: Cambridge, Mass., 48 p.

Pickhardt, P.C., and Fisher, N.S., 2007, Accumulation of inorganic and methylmercury by freshwater phytoplankton in two contrasting water bodies: Environmental Science and Technology, no. 41, p. 125-131.

Révész, Kinga, and Coplen, T.B., 2008a, Determination of the delta $(2 \mathrm{H} / 1 \mathrm{H})$ of water: RSIL lab code 1574, chap. C1 of Révész, Kinga, and Coplen, T.B., eds., Methods of the Reston Stable Isotope Laboratory: U.S. Geological Survey Techniques and Methods 10-C1, 27 p.

Révész, Kinga, and Coplen, Tyler, B., 2008b, Determination of the delta (180/16O) of water: RSIL lab code 489, chap. C2 of Révész, Kinga, and Coplen, Tyler B., eds., Methods of the Reston Stable Isotope Laboratory: U.S. Geological Survey Techniques and Methods, $10-\mathrm{C} 2,28 \mathrm{p}$.

Rytuba, J.J., 2000, Mercury mine drainage and processes that control its environmental impact. Science of the Total Environment, v. 260, p. 57-71.

Senko, J.M., Campbell, B.S., Henriksen, J.R., Elshahed, M.S., Dewers, T.A., and Krumholz, L.R., 2004, Barite deposition resulting from phototrophic sulfide-oxidizing bacterial activity: Geochimica et Cosmochimica Acta, v. 68, p. 773-780.

Slotton, D.G., Reuter, J.E., and Goldman, C.R., 1995, Mercury uptake patterns of biota in a seasonally anoxic northern California reservoir. Water Air and Soil Pollution, v. 80, p. $841-850$. 
Slotton, D.G., Ayers, S.M., Reuter, J.E., and Goldman, C.R., 1997, Cache Creek watershed preliminary mercury assessment, using benthic macro-invertebrates: Final report for the Central Valley Regional Water Quality Control Board and the National Science Foundation, June 1997.

Slotton, D.G., Ayers, S.M., Suchanek, T.H., Weyand, R.D., and Liston, A.M., 2004, Mercury bioaccumulation and trophic transfer in the Cache Creek Watershed of California, in relation to diverse aqueous mercury exposure conditions - Component 5B of the multiinstitution directed action research project: Assessment of ecological and human health impacts of mercury in the San Francisco Bay-Delta Watershed, a Cal-Fed Bay-Delta Program Project, Final report, January 25, 2004, 74 p., 63-p. appendix, accessed 9/17/11 at http://loer.tamug.tamu.edu/calfed/Report/Final/UCDavis_Cache_Bio_Final.pdf.

Slowey, A.J., and Rytuba, J.J., 2008, Mercury release from the Rathburn mine, Petray mine, and Bear Valley saline springs, Colusa County, California 2004-2006: U.S. Geological Survey Open-File Report 2008-1179, 49 p., accessed 9/17/11 at http://pubs.usgs.gov/of/2008/1179/.

Sofer, Z. and Gat, J. R., 1972. Activities and concentrations of oxygen-18 in concentrated aqueous salt solutions: analytical and geophysical implications. Earth Planetary Science Letters, v. 15, p. 232-238.

Sofer, Z. and Gat, J. R., 1975. The isotope composition of evaporating brines: Effect of the isotopic activity ratio in saline solutions. Earth Planetary Science Letters, v. 26, p. 179186.

Suchanek, T.H., Hothem, R.L., Rytuba, J.J., and Yee, J.L., 2010, Mercury assessment and monitoring protocol for the Bear Creek Watershed, Colusa County, California: U.S. Geological Survey Scientific Investigations Report 2010-5018, 34 p.

Ugarte, C.A., Rice, K.G., and Donnelly, M.A., 2005, Variation of total mercury concentrations in pig frogs (Rana grylio) across the Florida Everglades, USA: Science of the Total Environment, v. 345 p. 51-59.

U.S. Bureau of Mines, 1965, Mercury potential of the United States: U.S. Department of the Interior, Bureau of Mines, Information Circular 8252, 376 p.

U.S. Environmental Protection Agency, 1997, Mercury study report to Congress-U.S. Environmental Protection Agency, vol. VII - Characterization of human health and wildlife risks from mercury exposure in the United States, Washington, DC, EPA-452/R97-009, accessed 9/17/11 at: http://www.epa.gov/ttn/oarpg/t3/reports/volume7.pdf.

U.S. Environmental Protection Agency, 2001, Water quality criterion for the protection of human health-Methylmercury: U.S. Environmental Protection Agency, Washington, DC, EPA-823-R-01-001, accessed 9/17/11 at: http://www.epa.gov/waterscience/criteria/methylmercury/merctitl.pdf

U.S. Food and Drug Administration, 2001, Consumer advisory-An important message for pregnant women and women of child-bearing age who may become pregnant about the risks of mercury in fish: U.S. Food and Drug Administration, accessed 9/17/11 at: http://vm.cfsan.fda.gov/ dms/admehg.html.

Watts, W.L., 1893, Colusa County, eleventh feport of the State Mineralogist: Sacramento, California State Mining Bureau, p. 183-184.

Wiebelt, F.J., 1949, Investigation of the Abbott quicksilver mine, Lake County, California: U.S. Bureau of Mines, Report of Investigations 4558, 11 p., 3 figures. 
Table 1. Sample locations and physical parameters from waters collected from Harley Gulch, Lake County, California.

\begin{tabular}{|c|c|c|c|c|c|c|c|c|}
\hline $\begin{array}{c}\text { Field } \\
\text { number }\end{array}$ & $\begin{array}{l}\text { Latitude } \\
\text { Low-flow } \mathrm{J}\end{array}$ & $\begin{array}{l}\text { Longitude } \\
\text { ine } 2010\end{array}$ & $\begin{array}{l}\text { Collection } \\
\text { date }\end{array}$ & Location Description & $\begin{array}{c}\text { Water } \\
\text { conductivity } \\
\mu S / c m\end{array}$ & $\begin{array}{c}\text { Water } \\
\text { pH }\end{array}$ & $\begin{array}{c}\text { Water } \\
\text { temperature } \\
\operatorname{deg} C\end{array}$ & $\begin{array}{c}\text { Water } \\
\text { dissolved } \\
\mathrm{O}_{2}\end{array}$ \\
\hline 10HG1 & 39.0154 & -122.44023 & $6 / 16 / 10$ & Below Highway 20 culvert downstream from Turkey Run & 7,820 & 8.06 & 19.82 & 7.04 \\
\hline 10HG2 & 39.0134 & -122.43625 & $6 / 16 / 10$ & West Fork Harley Gulch downstream from end of wetland & 6,850 & 7.91 & 22.72 & 5.31 \\
\hline 10HG3 & 39.01037 & -122.43344 & $6 / 16 / 10$ & East Fork Harley Gulch & 1,438 & 8.33 & 29.31 & 9.67 \\
\hline 10HG4 & 39.01994 & -122.43426 & $6 / 17 / 10$ & Pool at water fall downstream from confluence East and West Fork & 3,560 & 7.50 & 16.78 & 7.15 \\
\hline 10HG5 & 39.00911 & -122.43530 & $6 / 17 / 10$ & Harley Gulch & 4,355 & 8.16 & 23.35 & 10.62 \\
\hline 10HG6 & 39.0084 & -122.4365 & $7 / 1 / 10$ & Harley Gulch area with biogenic sediment & 4,613 & 8.16 & 23.41 & 7.93 \\
\hline 10HG7 & 39.00743 & -122.43896 & $7 / 1 / 10$ & Upstream from biota site \#7 & 4,715 & 8.49 & 34.40 & 12.49 \\
\hline 10HG8 & 39.00675 & -122.44736 & $7 / 1 / 10$ & Pool near biota sample site \#8 & 4,150 & 7.94 & 23.35 & 9.34 \\
\hline 10HG9 & 39.00439 & -122.45496 & $7 / 1 / 10$ & Downstream from biota site $\# 9$ & 3,488 & 7.56 & 25.93 & 6.7 \\
\hline 10HG9.5 & 39.0032 & -122.45886 & $7 / 1 / 10$ & Between sites \#9 and \#10 - sediment sample only & & & & \\
\hline 10HG10 & $\begin{array}{c}39.00238 \\
\text { Low-flow S }\end{array}$ & $\begin{array}{l}-122.46398 \\
\text { ept. } 2010\end{array}$ & $7 / 1 / 10$ & Downstream from biota site \#10, intermittent pools & 3,280 & 7.63 & 22.16 & 7.63 \\
\hline 10HG4-2 & $\begin{array}{c}39.01994 \\
\text { Low-flow } \mathrm{N}\end{array}$ & $\begin{array}{l}-122.43426 \\
\text { Iay } 2011\end{array}$ & $9 / 16 / 10$ & Pool at water fall downstream from confluence East and West Fork & 5,174 & 6.99 & 17.21 & 2.7 \\
\hline 11HG1 & 39.01627 & -122.44001 & $5 / 25 / 11$ & Below Highway 20 culvert downstream from Turkey Run & 2,270 & 8.20 & 19.82 & \\
\hline $11 \mathrm{HG} 1.5$ & 39.01402 & -122.43709 & $5 / 25 / 11$ & Middle of Harley Gulch wetland & 5,560 & 8.26 & 17.00 & \\
\hline $11 \mathrm{HG} 2$ & 39.01068 & -122.43380 & $5 / 25 / 11$ & West Fork Harley Gulch downstream from end of wetland & 5,380 & 8.23 & 15.40 & \\
\hline $11 \mathrm{HG} 3$ & 39.01023 & -122.43330 & $5 / 25 / 11$ & East Fork Harley Gulch & 1,156 & 8.38 & 18.10 & \\
\hline 11HG4 & 39.0098 & -122.43419 & $5 / 25 / 11$ & Pool at water fall downstream from confluence East and West Fork & 3,200 & 8.32 & 17.40 & \\
\hline 11HG5 & 39.00904 & -122.43515 & $5 / 25 / 11$ & Harley Gulch & 3,040 & 8.39 & 16.70 & \\
\hline 11HG7 & $\begin{array}{c}39.00732 \\
\text { High-flow } ~\end{array}$ & $\begin{array}{l}-122.43953 \\
\text { March } 2011\end{array}$ & $5 / 25 / 11$ & Upstream from biota site \#7 & 3,040 & 8.49 & 19.40 & \\
\hline $11 \mathrm{HG} 1$ & 39.0154 & -122.44023 & $3 / 24 / 11$ & Below Highway 20 culvert downstream from Turkey Run & 725.1 & 6.91 & 19.62 & \\
\hline $11 \mathrm{HG} 2$ & 39.0134 & -122.43625 & $3 / 24 / 11$ & West Fork Harley Gulch downstream from end of wetland & 1,318 & 7.75 & 23.94 & \\
\hline $11 \mathrm{HG} 3$ & 39.01037 & -122.43344 & $3 / 24 / 11$ & East Fork Harley Gulch & 540.1 & 7.68 & 26.16 & \\
\hline 11HG4 & $\begin{array}{c}39.01994 \\
\text { High-flow J }\end{array}$ & $\begin{array}{l}-122.43426 \\
\text { une } 2011\end{array}$ & $3 / 24 / 11$ & Pool at water fall downstream from confluence East and West Fork & 1,060 & 7.75 & 25.38 & \\
\hline $11 \mathrm{HG} 1$ & 39.01627 & -122.44001 & $6 / 7 / 11$ & Below Highway 20 culvert downstream from Turkey Run & 3,160 & 8.23 & 18.20 & \\
\hline 11HG2 & 39.01068 & -122.43380 & $6 / 7 / 11$ & West Fork Harley Gulch downstream from end of wetland & 5,290 & 8.37 & 15.90 & \\
\hline $11 \mathrm{HG} 3$ & 39.01023 & -122.43330 & $6 / 7 / 11$ & East Fork Harley Gulch & 1,356 & 8.50 & 16.10 & \\
\hline
\end{tabular}


Table 2. Collection sites, for biological samples from Harley Gulch, Lake County, California, in 2007, 2008, 2010, and 2011.

\begin{tabular}{|c|c|c|c|c|}
\hline Site & Site description & Sample dates & Latitude & Longitude \\
\hline HG1 & "Wetlands at culvert & 5/21/08, 6/8/10,6/2/11 & $39^{\circ} \mathrm{N} 00^{\prime} 55.3^{\prime \prime}$ & $12122^{\circ} \mathrm{W} 26^{\prime} 25.0^{\prime \prime}$ \\
\hline UDUP & Wetlands-Upper unnamed drainage & $6 / 8 / 10$ & $39^{\circ} \mathrm{N} 00^{\prime} 53.2^{\prime \prime}$ & $122^{\circ} \mathrm{W} 26^{\prime} 19.9^{\prime \prime}$ \\
\hline HG8-07 & Harley Gulch Pond & $5 / 16 / 07$ & $39^{\circ} \mathrm{N} 00^{\prime} 48.5^{\prime \prime}$ & $122^{\circ} \mathrm{W} 26^{\prime} 10.9^{\prime \prime}$ \\
\hline HG2 & Mid point wetlands & $5 / 21 / 08,6 / 8 / 10,6 / 2 / 11$ & $39^{\circ} \mathrm{N} 00^{\prime} 47.8^{\prime \prime}$ & $122^{\circ} \mathrm{W} 26^{\prime} 11.1^{\prime \prime}$ \\
\hline UDLW & Wetlands-Lower unnamed drainage & $6 / 8 / 10$ & $39^{\circ} \mathrm{N} 00^{\prime} 42.0^{\prime \prime}$ & $122^{\circ} \mathrm{W} 26^{\prime} 6.0^{\prime \prime}$ \\
\hline $\mathrm{HG} 2 \mathrm{a}$ & Wetlands above confluence & $5 / 21 / 08,6 / 8 / 10,6 / 2 / 11$ & $39^{\circ} \mathrm{N} 00^{\prime} 38.5^{\prime \prime}$ & $122^{\circ} \mathrm{W} 26^{\prime} 01.7^{\prime \prime}$ \\
\hline HG3 & East Fork Harley Gulch (Reference) & $5 / 16 / 07,5 / 21 / 08,6 / 8 / 10,6 / 2 / 11$ & $39^{\circ} \mathrm{N} 00^{\prime} 37.2^{\prime \prime}$ & $122^{\circ} \mathrm{W} 26^{\prime} 01.5^{\prime \prime}$ \\
\hline HG4 & Just below confluence & $5 / 16 / 07,6 / 8 / 10,6 / 2 / 11,6 / 10 / 11$ & $39^{\circ} \mathrm{N} 00^{\prime} 36.1^{\prime \prime}$ & $122^{\circ} \mathrm{W} 26^{\prime} 03.9^{\prime \prime}$ \\
\hline HG5 & $200 \mathrm{~m}$ below confluence & $5 / 16 / 07,5 / 21 / 08,6 / 10 / 10,6 / 2 / 11,6 / 10 / 11$ & $39^{\circ} \mathrm{N} 00^{\prime} 32.4^{\prime \prime}$ & $122^{\circ} \mathrm{W} 26^{\prime} 08.4^{\prime \prime}$ \\
\hline HG6 & $320 \mathrm{~m}$ below confluence & $5 / 16 / 07,6 / 10 / 10$ & $39^{\circ} \mathrm{N} 00^{\prime} 30.1^{\prime \prime}$ & $122^{\circ} \mathrm{W} 26^{\prime} 11.2^{\prime \prime}$ \\
\hline HG7 & $600 \mathrm{~m}$ below confluence & $5 / 16 / 07,6 / 4 / 08,6 / 10 / 10,6 / 2 / 11$ & $39^{\circ} \mathrm{N} 00^{\prime} 26.3^{\prime \prime}$ & $122^{\circ} \mathrm{W} 26^{\prime} 21.9^{\prime \prime}$ \\
\hline HG8 & 740 m below site HG7 & $6 / 4 / 08,6 / 10 / 10$ & $39^{\circ} \mathrm{N} 00^{\prime} 24.4^{\prime \prime}$ & $122^{\circ} \mathrm{W} 26^{\prime} 50.6^{\prime \prime}$ \\
\hline HG8a & Fish pond & $6 / 10 / 10,6 / 17 / 10$ & $39^{\circ} \mathrm{N} 00^{\prime} 21.0^{\prime \prime}$ & $122^{\circ} \mathrm{W} 27^{\prime} 00.6^{\prime \prime}$ \\
\hline HG9 & $650 \mathrm{~m}$ below site HG8 & $6 / 4 / 08,6 / 10 / 10$ & $39^{\circ} \mathrm{N} 00^{\prime} 16.0^{\prime \prime}$ & $122^{\circ} \mathrm{W} 27^{\prime} 13.6^{\prime \prime}$ \\
\hline HG10 & 740 m below site HG9 & $6 / 4 / 08,6 / 10 / 10$ & $39^{\circ} \mathrm{N} 00^{\prime} 10.5^{\prime \prime}$ & $122^{\circ} \mathrm{W} 27^{\prime} 41.6^{\prime \prime}$ \\
\hline HG11 & $830 \mathrm{~m}$ below site HG10 & $6 / 4 / 08,6 / 17 / 10$ & $38^{\circ} \mathrm{N} 59^{\prime} 56.7^{\prime \prime}$ & $122^{\circ} \mathrm{W} 28^{\prime} 02.2^{\prime \prime}$ \\
\hline HG12 & $840 \mathrm{~m}$ below site HG11 & $6 / 4 / 08,6 / 17 / 10$ & $38^{\circ} \mathrm{N} 59^{\prime} 39.2^{\prime \prime}$ & $122^{\circ} \mathrm{W} 28^{\prime} 13.5^{\prime \prime}$ \\
\hline HG13 & 840 m below site HG12 & $6 / 4 / 08,6 / 17 / 10$ & $38^{\circ} \mathrm{N} 59^{\prime} 21.5^{\prime \prime}$ & $122^{\circ} \mathrm{W} 28^{\prime} 30.7^{\prime \prime}$ \\
\hline HG14 & $\begin{array}{l}390 \mathrm{~m} \text { below site HG13, } 220 \mathrm{~m} \\
\text { above Cache Creek }\end{array}$ & $6 / 4 / 08,6 / 17 / 10$ & $38^{\circ}$ N 59' $14.8^{\prime \prime}$ & $122^{\circ} \mathrm{W} 28^{\prime} 35.2^{\prime \prime}$ \\
\hline
\end{tabular}



Table 3. Mercury and monomethylmercury concentrations in waters and sediment collected in Harley Gulch, Lake County, California
Water Water Water percent T.S.S., D.O.C., Sediment Sediment percent

Water Water

$$
\begin{aligned}
& \text { percentDissolv } \\
& \text { ed }
\end{aligned}
$$

$\begin{array}{cccc}\text { Field } & \mathrm{Hg}_{\mathrm{T}} & \mathrm{Hg}_{\mathrm{F}} & \left(\mathrm{Hg}_{\mathrm{F}} / \mathrm{Hg}_{\mathrm{T}}\right) \\ \text { number } & \text { in } \mathrm{ng} / \mathrm{L} & \text { in } \mathrm{ng} / \mathrm{L} & \text { in water }\end{array}$

Low-flow June 2010

$\begin{array}{llrl}\text { 10HG1 } & 825 & 647 & 78.42 \\ \text { 10HG2 } & 552 & 100 & 18.12 \\ \text { 10HG3 } & 7.36 & 4.4 & 59.78 \\ \text { 10HG4 } & 234 & 90.3 & 38.59 \\ \text { 10HG5 } & 142 & 96.5 & 67.96\end{array}$

$\begin{array}{llll}10 H G 6 & 101 & 56.4 & 55.84\end{array}$

$\begin{array}{llll}10 \mathrm{HG7} & 58 & 40.9 & 70.52\end{array}$

$\begin{array}{llll}10 \mathrm{HG} 8 & 48.8 & 34.8 & 71.31\end{array}$

$\begin{array}{llll}10 \mathrm{HG} 9 & 23.9 & 15.5 & 64.85\end{array}$

10HG9.5

$10 \mathrm{HG} 10$

18.3

12.8

Low-flow Sept. 2010 10HG4 168

Low-flow May 2011

$\begin{array}{rccc}\text { 11HG1 } & 624 & 180 & 28.85 \\ \text { 11HG1.5 } & 2,300 & 811 & 35.26 \\ \text { 11HG2 } & 2,100 & 283 & 13.48 \\ \text { 11HG3 } & 5.24 & 2.68 & 51.15 \\ \text { 11HG4 } & 214 & 118 & 55.14 \\ \text { 11HG5 } & 137 & 102 & 74.45\end{array}$

$\begin{array}{llrr}11 \mathrm{HG} 7 & 102 & 84.5 & 82.84\end{array}$

High-flow March 2011

$\begin{array}{cccr}\text { 11HG1 } & 429,000 & 3390 & 0.79 \\ 11 \mathrm{HG} 2 & 32,800 & 266 & 0.81 \\ 11 \mathrm{HG} 3 & 32.8 & 15.7 & 47.87\end{array}$

11HG4 $11,000 \quad 2410 \quad 21.91$

High-flow June 2011

$\begin{array}{llll}11 \mathrm{HG} 1 & 301 & 151 & 50.17\end{array}$

$\begin{array}{ll}11 \mathrm{HG} 3 & 4.08\end{array}$
Water

\section{MMeHg \\ in $\mathrm{ng} / \mathrm{L}$}

\subsection{8}

12.1

0.552

2.14

0.52

0.881

2.35

0.947

0.511

0.176

1.03

7.43

1.54

1.38

0.054

0.62

0.621

0.804

15.8

2.29

0.153

0.481

2.82

1.39

0.058 percent MMeHg

\section{(MMeHg/Hg) in water}

0.02

2.19

7.50

0.91

0.37

0.87

4.05

1.94

2.14

0.96

0.61

1.19

0.07

0.07

1.03

0.29

0.45

0.79

0.00

0.01

0.47

0.00

0.94

0.45

1.42
T.S.S.,

mg/L

$\mathrm{mg} / \mathrm{L}$

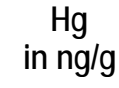

MMeHg

in $\mathrm{ng} / \mathrm{g}$

(MMeHg/Hg)

$2.7 \quad 57,800$

$\begin{array}{ll}11 & 35,900\end{array}$

$3.2 \quad 213$

$2.9 \quad 16,800$

$3.7 \quad 13,300$

$4.0 \quad 3,650$

$5.1 \quad 2,510$

$3.9 \quad 1,170$

$2.5 \quad 769$

$\quad 565$

$2.85 \quad 719$

$9.23 \quad 78,300$

$4.66 \quad 11,000$

$6.38 \quad 14,700$

$4.04 \quad 420$

$5.33 \quad 2760$

$4.68 \quad 18,800$

$5.57 \quad 11,900$

0.098
3.79
0.565
36.3
0.89
4.03
19.4
19.5
11.1
15.2
0.082

5.2

0.744
6.83
0.388
0.153
1.49
0.774
0.163

0.000

0.011

0.265

0.216

0.007

0.110

0.773

1.667

1.443

2.690

0.056

0.723

0.001

0.003

0.036

0.054

0.004

0.001 
Table 4. Concentration of anions and selected cations in filtered water from Harley Gulch sample sites

\begin{tabular}{|c|c|c|c|c|c|c|c|c|c|c|c|}
\hline $\begin{array}{c}\text { Field } \\
\text { number }\end{array}$ & $\begin{array}{c}\text { in } \mu \mathrm{g} / \mathrm{L} \\
\text { Low-flow } \mathrm{J}\end{array}$ & $\begin{array}{l}\text { in } \mu \mathrm{g} / \mathrm{L} \\
2010\end{array}$ & $\begin{array}{c}\mathrm{NO}_{3} \\
\text { in } \mu \mathrm{g} / \mathrm{L}\end{array}$ & in $\mu \mathrm{g} / \mathrm{L}$ & $\begin{array}{c}\text { Alkalinity } \\
\text { as } \mathrm{CaCO}_{3} \\
\text { in } \mu \mathrm{g} / \mathrm{L}\end{array}$ & in $\mathrm{mg} / \mathrm{L}$ & in $\mu \mathrm{g} / \mathrm{L}$ & in $\mathrm{mg} / \mathrm{L}$ & $\begin{array}{c}\mathrm{Li} \\
\text { in } \mu \mathrm{g} / \mathrm{L}\end{array}$ & in $\mathrm{mg} / \mathrm{L}$ & in $\mathrm{mg} / \mathrm{L}$ \\
\hline 10HG1 & $1,131.8$ & $<.08$ & 20.6 & 1,068 & $1,988.0$ & 42.8 & $<20$ & 34.1 & 1,520 & 617 & 1080 \\
\hline 10HG2 & 1,021 & $<.08$ & $<.08$ & 1,409 & $1,586.7$ & 50.8 & 84.2 & 21.9 & 1,080 & 552 & 855 \\
\hline 10HG3 & 43.6 & $<.08$ & $<.08$ & 321 & 913.8 & 53.1 & $<20$ & 4.41 & 171 & 119 & 101 \\
\hline 10HG4 & 403.4 & $<.08$ & $<.08$ & 751.4 & 474.6 & 46.7 & $<20$ & 9.35 & 522 & 276 & 430 \\
\hline 10HG5 & 572.6 & $<.08$ & $<.08$ & 959.3 & 807.1 & 43.8 & $<20$ & 10.8 & 626 & 330 & 522 \\
\hline 10HG6 & 748.5 & $<.04$ & $<.08$ & 1,196 & 934.8 & 39.5 & 23.8 & 12.1 & 670 & 294 & 542 \\
\hline 10HG7 & 874.5 & $<.04$ & $<.08$ & 1,424 & 907.3 & 24.7 & $<20$ & 11.1 & 677 & 309 & 562 \\
\hline 10HG8 & 511 & $<.04$ & $<.08$ & 942 & 780.5 & 54.5 & 21.8 & 9.1 & 508 & 271 & 457 \\
\hline 10HG9 & 484.1 & $<.04$ & $<.08$ & 1,015 & 623.9 & 76.9 & $<20$ & 7.8 & 386 & 213 & 355 \\
\hline 10HG10 & 431.9 & $<.04$ & $<.08$ & $1,034.4$ & 573.6 & 69.5 & $<20$ & 7.22 & 330 & 197 & 345 \\
\hline 10HG4 & $\begin{array}{c}\text { Low-flow S } \\
862 \\
\text { Low-flow }\end{array}$ & $\begin{array}{l}2010 \\
\quad<.04 \\
2011\end{array}$ & $<.08$ & 813.5 & 769.0 & 43.3 & 43 & 12.8 & 678 & 360 & 612 \\
\hline 11HG1 & 60.4 & $<0.04$ & $<0.08$ & 964.56 & 355.8 & 59 & $<50$ & 4.4 & 166 & 296 & $\mathrm{nr}$ \\
\hline $11 \mathrm{HG} 1.5$ & 762.6 & $<0.04$ & 51.6 & $1,275.5$ & $1,113.5$ & 59.8 & $<50$ & 18.9 & 1,070 & 457 & $\mathrm{nr}$ \\
\hline 11HG2 & 752.6 & $<0.04$ & $<0.08$ & $1,260.3$ & $1,030.0$ & 58.1 & $<50$ & 16 & 934 & 442 & $\mathrm{nr}$ \\
\hline $11 \mathrm{HG} 3$ & 29.6 & $<0.04$ & $<0.08$ & 201.6 & 428.6 & 53.9 & $<50$ & 2.2 & 76.7 & 146 & 70.9 \\
\hline 11HG4 & 354.2 & $<0.04$ & $<0.08$ & 684.6 & 659.3 & 53.5 & $<50$ & 8.6 & 530 & 279 & $\mathrm{nr}$ \\
\hline 11HG5 & 320.5 & $<0.04$ & $<0.08$ & 660 & 681.7 & 55.8 & $<50$ & 7.5 & 462 & 262 & $\mathrm{nr}$ \\
\hline 11HG7 & 391.9 & $<0.04$ & $<0.08$ & 759 & 682.1 & 50.4 & $<50$ & 7.9 & 503 & 269 & $\mathrm{nr}$ \\
\hline & \multicolumn{11}{|c|}{ High-flow March 2011} \\
\hline $11 \mathrm{HG} 1$ & 10.9 & 0.4 & 0.6 & 228.1 & 591.8 & 29 & 327 & 2 & 27.1 & 61.5 & 28.1 \\
\hline $11 \mathrm{HG} 2$ & 67.5 & $<0.04$ & 1.1 & 285 & $1,034.3$ & 23 & 62.7 & 4.5 & 127 & 80.1 & 101 \\
\hline $11 \mathrm{HG} 3$ & 4.8 & $<0.04$ & $<0.08$ & 30.2 & & 15.7 & 114 & 1.3 & 8.9 & 27.5 & 12.1 \\
\hline 11HG4 & 25.8 & $<0.04$ & 1.1 & 111 & & 17.9 & 646 & 2.4 & 51.5 & 45.5 & 41 \\
\hline & \multicolumn{11}{|c|}{ High-flow June 2011} \\
\hline 11HG1 & 101.6 & $<0.04$ & $<0.08$ & 1,379 & & & & & & & \\
\hline $11 \mathrm{HG} 2$ & 758.6 & $<0.04$ & $<0.08$ & $1,251.3$ & & & & & & & \\
\hline 11HG3 & 73.3 & $<0.04$ & $<0.08$ & 11 & & & & & & & \\
\hline
\end{tabular}


Table 5. Mercury and associated major and minor elements in active stream channel, biogenic, and storm sediment, Harley Gulch Field Type

As $\mathrm{Ba} \quad \mathrm{Be}$

Bi

$\mathrm{Ca}$

cd

Ce $\quad \mathrm{Co}$

Co $\mathrm{Cr}$

number

Low-flow June 2011

10HG1S2 Active Stream Channel 10HG2S2 Biogenic Sediment 10HG3S2 Active Stream Channel 10HG4-2S Biogenic Sediment 10HG4S2 Biogenic Sediment 10HG4-2-2S Biogenic Sediment 10HG5S2 Active Stream Channel 10HG6S Biogenic Sediment 10HG7S Biogenic Sediment 10HG7S2 Active Stream Channel 10HG8S2 Biogenic Sediment 10HG9S Active Stream Channel 10HG9.5S Biogenic Sediment 10HG9.5S2 Active Stream Channel 10 HG10S Active Stream Channel 10HG10S2 Active Stream Channel 10HG17S2 Biogenic Sediment 10HG20S Storm Sediment 10HG21S Biogenic Sediment 10HG22S Storm Sediment 10HG23S Biogenic Sediment Low-flow May 2011

11HG1S1-2 Active Stream Channel 11HG1S2-2 Storm Sediment

11HG1.5S1-2 Active Stream Channel 11HG1.5S2-2 Storm Sediment

11HG2S1-2 Active Stream Channel 11HG2S2-2 Storm Sediment

11HG3S1-2 Active Stream Channel 11HG3S2-2 Storm Sediment

11HG4S1-2 Active Stream Channel 11HG4S2-2 Storm Sediment

11HG5S1-2 Active Stream Channel 11HG5S2-2 Storm Sediment

11HG6S1-2 Active Stream Channel 11HG6S2-2 Storm Sediment in $\mu g / g$ in $\mu g / g$ percent in $\mu g / g$ in $\mu g / g$ in $\mu g / g$ in $\mu g / g$ percent in $\mu g / g$ in $\mu g / g$ in $\mu g / g$ in $\mu g / g$

\begin{tabular}{|c|c|c|c|c|c|c|c|c|c|c|c|}
\hline 44.7 & 0.09 & 6.68 & 13.1 & 440 & 1.26 & 0.17 & 0.87 & 0.11 & 42.5 & 43 & 511 \\
\hline 10.95 & 0.11 & 6.52 & 12.8 & 470 & 1.07 & 0.18 & 1.12 & 0.14 & 38.2 & 49.3 & 341 \\
\hline 0.31 & 0.17 & 8.41 & 15.2 & 800 & 1.2 & 0.19 & 0.86 & 0.14 & 36.7 & 18.2 & 111 \\
\hline 23.1 & 0.29 & 7.27 & 12.7 & 1,020 & 1.06 & 0.19 & 1.24 & 0.14 & 31.5 & 18.9 & 171 \\
\hline 9.83 & 0.15 & 6.64 & 9.8 & 600 & 0.96 & 0.13 & 4.62 & 0.13 & 29.5 & 14.4 & 173 \\
\hline 17.7 & 0.19 & 5.66 & 6.9 & 550 & 0.78 & 0.12 & 6.54 & 0.11 & 24.3 & 12.3 & 127 \\
\hline 6.84 & 0.13 & 7.72 & 17.2 & 2,390 & 1.26 & 0.18 & 1.44 & 0.14 & 39.8 & 30.3 & 392 \\
\hline 15.6 & 0.16 & 6.59 & 12.1 & 1,210 & 0.89 & 0.16 & 3.59 & 0.13 & 33.4 & 23 & 249 \\
\hline 5.6 & 0.06 & 2.96 & $<5$ & 580 & 0.4 & 0.06 & 19.7 & 0.05 & 13.15 & 7.5 & 80 \\
\hline 6.13 & 0.11 & 6.5 & 9 & 1,110 & 0.85 & 0.12 & 7.51 & 0.11 & 32.3 & 23.3 & 182 \\
\hline 1.95 & 0.11 & 6.68 & 11.3 & 610 & 0.74 & 0.12 & 6.26 & 0.09 & 24.7 & 17.8 & 132 \\
\hline 1.7 & 0.08 & 3.79 & 6 & 430 & 0.31 & 0.09 & 13.6 & 0.05 & 12.4 & 8.4 & 95 \\
\hline 0.39 & 0.24 & 8.98 & 17 & 690 & 1.34 & 0.21 & 0.54 & 0.12 & 36 & 18.4 & 107 \\
\hline 0.33 & 0.19 & 8.46 & 14.8 & 660 & 1.23 & 0.21 & 0.49 & 0.13 & 38.7 & 16.4 & 97 \\
\hline 0.06 & 0.2 & 9.19 & 16.4 & 410 & 1.16 & 0.15 & 0.68 & 0.09 & 30.2 & 18.1 & 107 \\
\hline 0.19 & 0.16 & 8.29 & 15.1 & 400 & 1.09 & 0.15 & 0.75 & 0.11 & 30.1 & 15.9 & 94 \\
\hline 1.87 & 0.13 & 7.6 & 10.8 & 420 & 0.89 & 0.16 & 4.33 & 0.11 & 25.6 & 16.8 & 100 \\
\hline 136 & 0.2 & 6.68 & 14.4 & 2,680 & 1.08 & 0.19 & 1.12 & 0.15 & 35.3 & 28.2 & 2,200 \\
\hline 16.1 & 0.24 & 6.67 & 10.8 & 650 & 1.02 & 0.17 & 1.51 & 0.13 & 30 & 17 & 207 \\
\hline 23.9 & 0.28 & 6.8 & 14.5 & 2,200 & 1.19 & 0.19 & 1.18 & 0.17 & 36.6 & 24.2 & 689 \\
\hline 50.3 & 0.13 & 3.96 & 8.8 & 590 & 0.63 & 0.1 & 4.14 & 0.11 & 18.6 & 16.1 & 681 \\
\hline 78.3 & 0.16 & 6.2 & 9.2 & 460 & 0.95 & 0.16 & 2.08 & 0.08 & 34.2 & 36.7 & 516 \\
\hline$>100$ & 0.16 & 6.16 & 10.3 & 490 & 0.91 & 0.16 & 1.43 & 0.08 & 33.3 & 37 & 3,160 \\
\hline 11 & 0.07 & 7.46 & 19.1 & 470 & 1.18 & 0.17 & 1.79 & 0.13 & 39.6 & 29.5 & 368 \\
\hline 14.4 & 0.19 & 7.33 & 14.8 & 1,400 & 1.17 & 0.17 & 0.96 & 0.11 & 34.9 & 23.8 & 682 \\
\hline 14.7 & 0.25 & 7.5 & 13.7 & 2,320 & 1.09 & 0.18 & 0.94 & 0.13 & 33 & 22.3 & 449 \\
\hline 24.2 & 0.28 & 7.33 & 12.8 & 1,600 & 0.97 & 0.19 & 1.05 & 0.11 & 31.2 & 24.3 & 281 \\
\hline 0.42 & 0.23 & 7.79 & 15.5 & 620 & 1.03 & 0.19 & 0.68 & 0.11 & 31.2 & 16.8 & 128 \\
\hline 0.21 & 0.25 & 8.28 & 13.5 & 640 & 1.03 & 0.19 & 0.69 & 0.1 & 29.8 & 17.7 & 110 \\
\hline 2.76 & 0.19 & 7.39 & 12.8 & 670 & 0.91 & 0.15 & 1.26 & 0.1 & 25 & 18.8 & 110 \\
\hline 48.5 & 0.26 & 7.54 & 13.7 & 2,450 & 1.02 & 0.19 & 0.82 & 0.1 & 35.3 & 24 & 1,080 \\
\hline 18.8 & 0.21 & 7.38 & 14 & 1,260 & 0.96 & 0.17 & 1.32 & 0.1 & 32.4 & 23.4 & 341 \\
\hline 31.2 & 0.18 & 6.05 & 12.5 & 450 & 1.09 & 0.16 & 2.13 & 0.09 & 34.1 & 39.7 & 336 \\
\hline 11.9 & 0.19 & 7.21 & 13.8 & 980 & 0.91 & 0.16 & 1.01 & 0.08 & 29.7 & 20.8 & 254 \\
\hline 8.9 & 0.19 & 7.19 & 13 & 1,140 & 0.9 & 0.15 & 1.47 & 0.09 & 30.5 & 25.8 & 251 \\
\hline
\end{tabular}


Table 5 (cont'd).

Field

Type

Cs

$\mathrm{Cu}$

$\mathrm{Fe}$

Ga

Ge

Hf

In

K

La

Li

$\mathrm{Mg}$

Mn

number

Low-flow June 2011

10HG1S2 Active Stream Channel 10HG2S2 Biogenic Sediment 10HG3S2 Active Stream Channel 10HG4-2S Biogenic Sediment 10HG4S2 Biogenic Sediment 10HG4-2-2S Biogenic Sediment 10HG5S2 Active Stream Channel 10HG6S Biogenic Sediment 10HG7S Biogenic Sediment 10HG7S2 Active Stream Channel 10HG8S2 Biogenic Sediment 10HG9S Active Stream Channel 10HG9.5S Biogenic Sediment 10HG9.5S2 Active Stream Channel 10 HG10S Active Stream Channel 10HG10S2 Active Stream Channel 10HG17S2 Biogenic Sediment 10HG20S Storm Sediment 10HG21S Biogenic Sediment 10HG22S Storm Sediment 10HG23S Biogenic Sediment Low-flow May 2011

11HG1S1-2 Active Stream Channel 11HG1S2-2 Storm Sediment

11HG1.5S1-2 Active Stream Channel 11HG1.5S2-2 Storm Sediment

11HG2S1-2 Active Stream Channel 11HG2S2-2 Storm Sediment

11HG3S1-2 Active Stream Channel 11HG3S2-2 Storm Sediment

11HG4S1-2 Active Stream Channel 11HG4S2-2 Storm Sediment

11HG5S1-2 Active Stream Channel 11HG5S2-2 Storm Sediment

11HG6S1-2 Active Stream Channel 11HG6S2-2 Storm Sediment in $\mu \mathrm{g} / \mathrm{g}$ in $\mu \mathrm{g} / \mathrm{g}$ percent in $\mu \mathrm{g} / \mathrm{g}$ in $\mu \mathrm{g} / \mathrm{g}$ in $\mu \mathrm{g} / \mathrm{g}$ in $\mu \mathrm{g} / \mathrm{g}$ percent in $\mu \mathrm{g} / \mathrm{g}$ in $\mu \mathrm{g} / \mathrm{g}$ percent in $\mu \mathrm{g} / \mathrm{g}$

\begin{tabular}{|c|c|c|c|c|c|c|c|c|c|c|c|}
\hline 28.2 & 45 & 5.05 & 15.4 & 0.2 & 2.7 & 0.062 & 1.35 & 18.6 & 72.8 & 5.15 & 957 \\
\hline 13.3 & 50.2 & 4.97 & 14.6 & 0.2 & 2.5 & 0.054 & 1.26 & 17.8 & 80 & 4.21 & 1,280 \\
\hline 5.83 & 69.4 & 5.22 & 17.95 & 0.16 & 2.5 & 0.071 & 1.28 & 16.1 & 87.6 & 1.47 & 631 \\
\hline 7.74 & 79.8 & 4.83 & 15.55 & 0.15 & 1.8 & 0.061 & 1.2 & 13.1 & 108 & 1.75 & 397 \\
\hline 8.06 & 53.8 & 3.73 & 13.6 & 0.13 & 2 & 0.058 & 1.05 & 13.4 & 73.8 & 1.37 & 408 \\
\hline 6.89 & 45 & 3.28 & 12.1 & 0.13 & 1.6 & 0.044 & 0.93 & 11.1 & 89.1 & 1.34 & 359 \\
\hline 12.9 & 65.1 & 5.71 & 16.5 & 0.15 & 2.2 & 0.067 & 1.27 & 16.4 & 86.1 & 2.49 & 994 \\
\hline 9.84 & 49.8 & 4.17 & 13.95 & 0.16 & 2 & 0.056 & 1.12 & 14.3 & 94.1 & 1.74 & 657 \\
\hline 3.66 & 21.6 & 1.7 & 5.76 & 0.05 & 0.8 & 0.023 & 0.48 & 5.9 & 43.6 & 0.88 & 169 \\
\hline 9.62 & 47.4 & 3.89 & 13.4 & 0.15 & 1.9 & 0.054 & 1.04 & 12.9 & 72.9 & 1.87 & 568 \\
\hline 5.39 & 47.1 & 4.13 & 13.7 & 0.13 & 1.7 & 0.063 & 0.93 & 10.8 & 69.1 & 1.57 & 381 \\
\hline 2.35 & 27.7 & 2.1 & 7.16 & 0.06 & 1 & 0.036 & 0.53 & 6 & 44.3 & 0.89 & 239 \\
\hline 4.68 & 78.5 & 5.56 & 19.55 & 0.15 & 2.6 & 0.068 & 1.4 & 15.7 & 110.5 & 1.16 & 695 \\
\hline 4.99 & 69.5 & 5.1 & 18.2 & 0.16 & 2.5 & 0.077 & 1.33 & 17.8 & 87 & 1.1 & 656 \\
\hline 3.3 & 70.6 & 5.52 & 20.5 & 0.15 & 2.2 & 0.068 & 1.29 & 13.3 & 116 & 1.45 & 450 \\
\hline 3.77 & 62.7 & 4.65 & 18.95 & 0.14 & 2.2 & 0.078 & 1.15 & 14.4 & 90 & 1.31 & 407 \\
\hline 4.1 & 52.9 & 4.12 & 15.75 & 0.13 & 1.9 & 0.064 & 1.03 & 11.7 & 73.2 & 1.35 & 377 \\
\hline 15.8 & 55.8 & 5.27 & 15.3 & 0.18 & 2.1 & 0.058 & 1.23 & 15.5 & 101 & 2.29 & 721 \\
\hline 7.39 & 58.4 & 4.18 & 14.6 & 0.16 & 1.9 & 0.056 & 1.11 & 13.1 & 103.5 & 1.38 & 296 \\
\hline 12.05 & 63.8 & 5.04 & 15.9 & 0.19 & 2.3 & 0.062 & 1.22 & 15.8 & 101 & 1.97 & 792 \\
\hline 9.62 & 37.8 & 2.75 & 8.85 & 0.13 & 1.2 & 0.032 & 0.78 & 8.4 & 74.2 & 2.22 & 325 \\
\hline 9.99 & 43.7 & 4.89 & 13.95 & 0.17 & 2.2 & 0.053 & 1.18 & 15.7 & 65 & 3.16 & 692 \\
\hline 7.98 & 41.5 & 5.17 & 12.95 & 0.19 & 2.1 & 0.054 & 1.16 & 15.5 & 58.4 & 2.71 & 680 \\
\hline 17.25 & 57.5 & 5.86 & 17 & 0.19 & 2.4 & 0.061 & 1.4 & 16.5 & 107.5 & 3.17 & 783 \\
\hline 11.1 & 64.2 & 5.12 & 17.45 & 0.14 & 2 & 1.23 & 15 & 107 & 1.76 & 658 & 1.49 \\
\hline 16 & 62.6 & 4.94 & 16.85 & 0.18 & 2.2 & 0.071 & 1.29 & 14.4 & 90.2 & 1.98 & 720 \\
\hline 16.35 & 61.7 & 4.89 & 15.6 & 0.19 & 2.2 & 0.072 & 1.25 & 13.9 & 81.1 & 2.09 & 760 \\
\hline 5.28 & 68.6 & 5.09 & 17.05 & 0.17 & 2.2 & 0.073 & 1.22 & 13.9 & 86.4 & 1.38 & 632 \\
\hline 5.33 & 67.9 & 5.13 & 17.4 & 0.19 & 2.2 & 0.077 & 1.25 & 13.8 & 83.2 & 1.43 & 588 \\
\hline 6.39 & 59.8 & 4.83 & 15.8 & 0.17 & 1.8 & 0.065 & 1.12 & 10.8 & 84.1 & 1.71 & 553 \\
\hline 17.95 & 62 & 5.02 & 15.8 & 0.21 & 2.3 & 0.069 & 1.34 & 16.1 & 80.5 & 2.08 & 678 \\
\hline 12.3 & 60.7 & 5.1 & 15.45 & 0.2 & 2.2 & 0.067 & 1.21 & 14.4 & 81.5 & 2.12 & 706 \\
\hline 10.2 & 48.3 & 4.95 & 15 & 0.16 & 2.2 & 0.057 & 1.15 & 15.6 & 88.2 & 3.75 & 785 \\
\hline 10.8 & 57.3 & 4.95 & 14.95 & 0.2 & 2 & 0.065 & 1.18 & 13.1 & 77.3 & 1.82 & 592 \\
\hline 11.6 & 59.4 & 5.17 & 15.05 & 0.22 & 2.1 & 0.069 & 1.14 & 13.7 & 81.4 & 2.47 & 675 \\
\hline
\end{tabular}


Table 5 (cont'd).

Field

Type

Mo

$\mathrm{Na}$

$\mathrm{Nb}$

$\mathrm{Ni}$

$\mathrm{P}$

$\mathrm{Pb}$

$\mathrm{Rb}$

$\operatorname{Re}$

S

$\mathrm{Sb} \quad \mathrm{Sc}$

Se

Sn

number

Low-flow June 2011

10HG1S2 Active Stream Channel 10HG2S2 Biogenic Sediment 10HG3S2 Active Stream Channel 10HG4-2S Biogenic Sediment 10HG4S2 Biogenic Sediment 10HG4-2-2S Biogenic Sediment 10HG5S2 Active Stream Channel 10HG6S Biogenic Sediment 10HG7S Biogenic Sediment 10HG7S2 Active Stream Channel 10HG8S2 Biogenic Sediment 10HG9S Active Stream Channel 10HG9.5S Biogenic Sediment 10HG9.5S2 Active Stream Channel 10 HG10S Active Stream Channel 10HG10S2 Active Stream Channel 10HG17S2 Biogenic Sediment 10HG20S Storm Sediment 10HG21S Biogenic Sediment 10HG22S Storm Sediment 10HG23S Biogenic Sediment Low-flow May 2011

11HG1S1-2 Active Stream Channel 11HG1S2-2 Storm Sediment

11HG1.5S1-2 Active Stream Channel 11HG1.5S2-2 Storm Sediment

11HG2S1-2 Active Stream Channel 11HG2S2-2 Storm Sediment

11HG3S1-2 Active Stream Channel 11HG3S2-2 Storm Sediment

11HG4S1-2 Active Stream Channel 11HG4S2-2 Storm Sediment

11HG5S1-2 Active Stream Channel 11HG5S2-2 Storm Sediment

11HG6S1-2 Active Stream Channel 11HG6S2-2 Storm Sediment in $\mu g / g$ percent in $\mu g / g$ in $\mu g / g$ in $\mu g / g$ in $\mu g / g$ in $\mu g / g$ in $\mu g / g$ percent in $\mu g / g$ in $\mu g / g$ in $\mu g / g$ in $\mu g / g$

\begin{tabular}{|c|c|c|c|c|c|c|c|c|c|c|c|c|}
\hline 1.02 & 0.76 & 7.6 & 552 & 440 & 12.8 & 62.8 & $<0.002$ & 0.07 & 3.99 & 16.8 & 1 & 1.4 \\
\hline 1 & 0.88 & 6.9 & 582 & 540 & 12.6 & 56.5 & $<0.002$ & 0.35 & 2.36 & 17.2 & 2 & 1.4 \\
\hline 1.88 & 0.81 & 5.7 & 64.4 & 400 & 11.8 & 53.6 & $<0.002$ & 0.07 & 1.21 & 20.4 & 2 & 1.3 \\
\hline 1.5 & 0.81 & 5.3 & 116.5 & 500 & 11.1 & 51.2 & $<0.002$ & 0.29 & 2.45 & 17.9 & 2 & 1.2 \\
\hline 1.14 & 0.79 & 4.9 & 90.8 & 800 & 9 & 46 & $<0.002$ & 0.31 & 1.17 & 16 & 3 & 1 \\
\hline 0.96 & 0.83 & 4.6 & 75.6 & 730 & 7.6 & 52.1 & $<0.002$ & 0.42 & 0.89 & 13.5 & 2 & 1 \\
\hline 1.51 & 0.82 & 5.4 & 206 & 500 & 13.2 & 53 & $<0.002$ & 0.1 & 1.74 & 19.5 & 2 & 1.2 \\
\hline 1.02 & 0.94 & 4.8 & 143.5 & 530 & 10.9 & 60 & $<0.002$ & 0.57 & 1.47 & 18 & 3 & 6.6 \\
\hline 0.57 & 0.65 & 1.9 & 44.2 & 390 & 4.1 & 24.8 & $<0.002$ & 0.43 & 0.46 & 7.5 & 3 & 1.6 \\
\hline 0.74 & 0.78 & 4.4 & 155 & 470 & 9.1 & 42.9 & $<0.002$ & 0.13 & 1.37 & 15.7 & 2 & 1 \\
\hline 0.72 & 0.82 & 3.7 & 97.8 & 500 & 7.5 & 36.3 & $<0.002$ & 0.41 & 1.13 & 17 & 2 & 0.9 \\
\hline 2.05 & 0.7 & 1.9 & 41.8 & 440 & 4.6 & 25.8 & $<0.002$ & 0.66 & 0.47 & 10 & 4 & 3.6 \\
\hline 2.17 & 0.68 & 7.2 & 68.6 & 410 & 12.9 & 62.2 & $<0.002$ & 0.04 & 1.33 & 21.8 & 2 & 1.4 \\
\hline 2.1 & 0.66 & 6.3 & 62.2 & 380 & 12.1 & 59 & $<0.002$ & 0.04 & 1.23 & 20.5 & 2 & 1.3 \\
\hline 0.84 & 0.88 & 6.1 & 55.3 & 530 & 9.5 & 49 & 0.002 & 0.05 & 1 & 25.2 & 2 & 1.2 \\
\hline 0.93 & 0.85 & 5.2 & 51.4 & 380 & 9.1 & 47.6 & $<0.002$ & 0.07 & 1.04 & 22.6 & 2 & 1.2 \\
\hline 0.68 & 0.89 & 3.9 & 59.7 & 380 & 7.2 & 39.6 & $<0.002$ & 0.1 & 0.92 & 19.7 & 2 & 1.2 \\
\hline 1.48 & 0.88 & 6 & 260 & 380 & 12.5 & 61.5 & $<0.002$ & 0.14 & 1.94 & 16.8 & 2 & 1.3 \\
\hline 1.54 & 0.86 & 5.3 & 109 & 520 & 10.2 & 52.7 & $<0.002$ & 0.64 & 1.47 & 16.7 & 2 & 1.1 \\
\hline 2.01 & 0.8 & 6.3 & 206 & 400 & 13.2 & 60.6 & $<0.002$ & 0.13 & 1.75 & 17.5 & 2 & 1.2 \\
\hline 0.98 & 1.42 & 3.5 & 179.5 & 1,340 & 7 & 40.1 & $<0.002$ & 0.98 & 1.49 & 9.9 & 2 & 0.7 \\
\hline 0.45 & 0.73 & 6.3 & 528 & 340 & 10.9 & 63.3 & $<0.002$ & 0.05 & 2.41 & 14.4 & 2 & 1.9 \\
\hline 0.5 & 0.76 & 6 & 413 & 340 & 11.4 & 56.2 & $<0.002$ & 0.09 & 2.4 & 13.4 & 1 & 1.3 \\
\hline 1.01 & 0.83 & 6.7 & 336 & 570 & 13.1 & 79.6 & $<0.002$ & 0.05 & 2.56 & 21.2 & 2 & 1.4 \\
\hline 0.83 & 6.2 & 155.5 & 420 & 12.6 & 60.3 & $<0.002$ & 0.06 & 1.53 & 20.1 & 2 & 2.9 & 246 \\
\hline 1.43 & 0.7 & 6 & 178 & 400 & 14.2 & 62.6 & $<0.002$ & 0.1 & 1.84 & 17.6 & 2 & 1.4 \\
\hline 1.28 & 0.64 & 6 & 228 & 380 & 14.1 & 50.3 & $<0.002$ & 0.06 & 1.98 & 16 & 2 & 1.3 \\
\hline 1.62 & 0.73 & 5.6 & 70.3 & 400 & 11.4 & 57.4 & $<0.002$ & 0.03 & 1.18 & 18.2 & 2 & 1.3 \\
\hline 1.23 & 0.91 & 5.6 & 70 & 380 & 10.3 & 54.9 & $<0.002$ & 0.04 & 1.09 & 18.7 & 2 & 1.3 \\
\hline 0.91 & 0.82 & 4.6 & 93.6 & 400 & 9.9 & 41.2 & $<0.002$ & 0.04 & 1.07 & 17.3 & 2 & 1.1 \\
\hline 1.32 & 0.81 & 6.3 & 197.5 & 380 & 12.9 & 65.9 & $<0.002$ & 0.1 & 1.72 & 16.7 & 2 & 1.3 \\
\hline 1.23 & 0.83 & 5.4 & 187.5 & 430 & 11.4 & 60.1 & $<0.002$ & 0.06 & 1.61 & 16.6 & 2 & 1.2 \\
\hline 0.75 & 0.73 & 6.1 & 537 & 450 & 12.6 & 63.5 & $<0.002$ & 0.06 & 3.82 & 16.2 & 2 & 1.3 \\
\hline 1.06 & 0.88 & 5.1 & 151.5 & 370 & 10.6 & 52.9 & $<0.002$ & 0.04 & 1.58 & 16.2 & 2 & 1.2 \\
\hline 0.88 & 0.8 & 5 & 236 & 410 & 10.2 & 54.5 & $<0.002$ & 0.05 & 1.87 & 16.9 & 2 & 1.2 \\
\hline
\end{tabular}


Table 5 (cont'd).

number

Low-flow June 2011

10HG1S2 Active Stream Channel 10HG2S2 Biogenic Sediment 10HG3S2 Active Stream Channel 10HG4-2S Biogenic Sediment 10HG4S2 Biogenic Sediment 10HG4-2-2S Biogenic Sediment 10HG5S2 Active Stream Channel 10HG6S Biogenic Sediment 10HG7S Biogenic Sediment 10HG7S2 Active Stream Channel 10HG8S2 Biogenic Sediment 10HG9S Active Stream Channel 10HG9.5S Biogenic Sediment 10HG9.5S2 Active Stream Channel 10 HG10S Active Stream Channel 10HG10S2 Active Stream Channel 10HG17S2 Biogenic Sediment 10HG20S Storm Sediment 10HG21S Biogenic Sediment 10HG22S Storm Sediment 10HG23S Biogenic Sediment Low-flow May 2011

11HG1S1-2 Active Stream Channel 11HG1S2-2 Storm Sediment

11HG1.5S1-2 Active Stream Channel 11HG1.5S2-2 Storm Sediment

11HG2S1-2 Active Stream Channel 11HG2S2-2 Storm Sediment

11HG3S1-2 Active Stream Channel 11HG3S2-2 Storm Sediment

11HG4S1-2 Active Stream Channel 11HG4S2-2 Storm Sediment

11HG5S1-2 Active Stream Channel 11HG5S2-2 Storm Sediment

11HG6S1-2 Active Stream Channel 11HG6S2-2 Storm Sediment in $\mu g / g$ in $\mu g / g$ in $\mu g / g$ in $\mu g / g$ percent in $\mu g / g$ in $\mu g / g$ in $\mu g / g$ in $\mu g / g$ in $\mu g / g$ in $\mu g / g$ in $\mu g / g$

\begin{tabular}{|c|c|c|c|c|c|c|c|c|c|c|c|}
\hline 305 & 0.55 & 0.11 & 6.5 & 0.323 & 0.98 & 1.8 & 128 & 10.3 & 15.3 & 158 & 80.4 \\
\hline 257 & 0.53 & 0.13 & 6 & 0.321 & 1 & 1.8 & 120 & 18.4 & 15.2 & 196 & 75.6 \\
\hline 208 & 0.42 & 0.15 & 5.1 & 0.398 & 0.33 & 1.7 & 162 & 1.8 & 16.1 & 128 & 67.6 \\
\hline 325 & & 0.34 & 4.6 & 0.353 & 0.44 & 1.6 & 143 & 7.2 & 14.3 & 124 & 62.8 \\
\hline 1,215 & 0.36 & 0.11 & 4 & 0.32 & 0.46 & 1.6 & 115 & 3.4 & 12.5 & 204 & 59.8 \\
\hline 1,590 & & 0.29 & 4.1 & 0.276 & 0.38 & 1.7 & 98 & 3 & 11.2 & 152 & 57.4 \\
\hline 409 & 0.4 & 0.16 & 5 & 0.355 & 0.59 & 1.6 & 158 & 20.2 & 16.2 & 145 & 63.2 \\
\hline 1,065 & 0.34 & 0.11 & 4.4 & 0.319 & 0.48 & 1.5 & 119 & 12.3 & 13.5 & 127 & 59.3 \\
\hline 5,660 & 0.13 & 0.1 & 1.7 & 0.141 & 0.21 & 1.5 & 50 & 8.9 & 6.4 & 59 & 24 \\
\hline 2,000 & 0.32 & 0.13 & 3.7 & 0.298 & 0.53 & 1.6 & 117 & 10.7 & 13 & 107 & 53.5 \\
\hline 1,555 & 0.27 & 0.1 & 3 & 0.3 & 0.43 & 1.3 & 116 & 3.7 & 12 & 102 & 48.1 \\
\hline 3,110 & 0.14 & 0.08 & 1.7 & 0.171 & 0.16 & 1.5 & 63 & 43.8 & 6.8 & 55 & 26.9 \\
\hline 102 & 0.52 & 0.13 & 6.2 & 0.431 & 0.37 & 1.8 & 174 & 1.1 & 16.2 & 132 & 80.6 \\
\hline 93.5 & 0.47 & 0.15 & 5.9 & 0.402 & 0.37 & 2 & 162 & 1.2 & 17 & 130 & 74.9 \\
\hline 139.5 & 0.41 & 0.1 & 4.8 & 0.453 & 0.31 & 1.4 & 190 & 1.2 & 15.2 & 132 & 68.4 \\
\hline 157 & 0.37 & 0.11 & 4.4 & 0.396 & 0.34 & 1.5 & 165 & 1.5 & 13.6 & 119 & 61.8 \\
\hline 913 & 0.28 & 0.11 & 3.4 & 0.341 & 0.35 & 1.4 & 138 & 2.7 & 12.6 & 109 & 53.7 \\
\hline 337 & $<0.2$ & 0.38 & 5.3 & 0.345 & 0.68 & 1.7 & 141 & 22.6 & 15.6 & 124 & 75 \\
\hline 355 & $<0.2$ & 0.35 & 4.5 & 0.324 & 0.46 & 1.7 & 125 & 5.2 & 13.6 & 153 & 63.1 \\
\hline 354 & $<0.2$ & 0.4 & 5.4 & 0.341 & 0.61 & 1.8 & 135 & 21.6 & 17.6 & 127 & 76.7 \\
\hline 1,515 & $<0.2$ & 0.22 & 2.9 & 0.196 & 0.81 & 1.3 & 79 & 5 & 8.7 & 419 & 44.4 \\
\hline 387 & 0.47 & 0.09 & 5.3 & 0.325 & 0.99 & 1.6 & 121 & 6.1 & 13.7 & 132 & 69.1 \\
\hline 259 & 0.44 & 0.09 & 4.9 & 0.322 & 0.92 & 1.4 & 134 & 5.3 & 12.6 & 118 & 63.4 \\
\hline 493 & 0.46 & 0.13 & 5.6 & 0.37 & 1.06 & 1.8 & 160 & 7.8 & 15.7 & 154 & 79.6 \\
\hline 0.41 & 0.1 & 5 & 0.372 & 0.53 & 1.6 & 157 & 12.9 & 16.1 & 128 & 65.4 & \\
\hline 336 & 0.44 & 0.13 & 4.9 & 0.367 & 0.72 & 1.6 & 152 & 24.5 & 14.2 & 134 & 66.7 \\
\hline 338 & 0.45 & 0.12 & 4.6 & 0.36 & 0.68 & 1.6 & 147 & 32.9 & 13.5 & 119 & 64.1 \\
\hline 157.5 & 0.42 & 0.14 & 4.7 & 0.388 & 0.34 & 1.6 & 159 & 1.8 & 14.5 & 123 & 63.2 \\
\hline 143.5 & 0.41 & 0.13 & 4.5 & 0.406 & 0.33 & 1.6 & 169 & 1.9 & 13.8 & 125 & 62.4 \\
\hline 303 & 0.33 & 0.11 & 3.7 & 0.368 & 0.38 & 1.3 & 156 & 4.6 & 12 & 122 & 54.3 \\
\hline 284 & 0.47 & 0.14 & 5.4 & 0.377 & 0.64 & 1.7 & 153 & 24.3 & 14 & 124 & 67.2 \\
\hline 351 & 0.4 & 0.12 & 4.7 & 0.366 & 0.54 & 1.5 & 148 & 17.4 & 14.5 & 120 & 66.2 \\
\hline 525 & 0.45 & 0.11 & 5.3 & 0.305 & 1.5 & 1.6 & 123 & 9.5 & 15.3 & 127 & 68.8 \\
\hline 263 & 0.38 & 0.12 & 4.2 & 0.36 & 0.5 & 1.4 & 146 & 13.5 & 12.7 & 112 & 57.9 \\
\hline 404 & 0.35 & 0.13 & 4.1 & 0.348 & 0.64 & 1.4 & 149 & 17.7 & 13.8 & 116 & 61.7 \\
\hline
\end{tabular}


Table 6. Unfiltered water, major and minor element concentrations from ICP-MS results (ICP-AES for major elements), Harley Gulch, Lake County, California.

\begin{tabular}{|c|c|c|c|c|c|c|c|c|c|c|c|c|c|c|c|}
\hline $\begin{array}{c}\text { Field } \\
\text { Number }\end{array}$ & $\begin{array}{c}\mathrm{Ag} \\
\text { in } \mu \mathrm{g} / \mathrm{L} \\
\text { Low-flow }\end{array}$ & $\begin{array}{c}\text { Al } \\
\text { in } \mu \mathrm{g} / \mathrm{L} \\
\text { June } 2010\end{array}$ & $\begin{array}{c}\text { As } \\
\text { in } \mu g / L\end{array}$ & $\begin{array}{c}\text { B } \\
\text { in } \mu g / L\end{array}$ & $\begin{array}{c}\mathrm{Ba} \\
\text { in } \mu \mathrm{g} / \mathrm{L}\end{array}$ & $\begin{array}{c}\text { Be } \\
\text { in } \mu g / L\end{array}$ & $\begin{array}{c}B i \\
\text { in } \mu g / L\end{array}$ & $\begin{array}{c}\mathrm{Ca} \\
\text { in } \mathrm{mg} / \mathrm{L}\end{array}$ & $\begin{array}{c}\text { Cd } \\
\text { in } \mu g / L\end{array}$ & $\begin{array}{c}\text { Ce } \\
\text { in } \mu g / L\end{array}$ & $\begin{array}{c}\text { Co } \\
\text { in } \mu g / L\end{array}$ & $\begin{array}{c}\mathrm{Cr} \\
\text { in } \mu \mathrm{g} / \mathrm{L}\end{array}$ & $\begin{array}{c}\text { Cs } \\
\text { in } \mu g / L\end{array}$ & $\begin{array}{c}\mathrm{Cu} \\
\text { in } \mu \mathrm{g} / \mathrm{L}\end{array}$ & $\begin{array}{c}\text { Dy } \\
\text { in } \mu \mathrm{g} / \mathrm{L}\end{array}$ \\
\hline 10HG1 & $<1$ & 47.8 & 8.3 & 40,600 & 82.6 & $<0.05$ & $<0.2$ & 40.7 & $<0.02$ & 0.12 & 0.61 & 15.8 & 35.9 & 3.7 & 0.03 \\
\hline 10HG2 & $<1$ & 2830 & 15.5 & 33,300 & 176 & 0.08 & $<0.2$ & 51.7 & 0.02 & 2.21 & 9.73 & 39.1 & 0.97 & 9.1 & 0.28 \\
\hline 10HG3 & $<1$ & 84.5 & 1 & 2,400 & 92.7 & $<0.05$ & $<0.2$ & 51.5 & $<0.02$ & 0.1 & 0.12 & 5 & 0.03 & 2 & 0.03 \\
\hline 10HG4 & $<1$ & 7.7 & 3.8 & 14,300 & 52.4 & $<0.05$ & $<0.2$ & 43.7 & $<0.02$ & 0.02 & 0.1 & 9.1 & 0.21 & 2.9 & 0.009 \\
\hline 10HG5 & $<1$ & 15.1 & 4.6 & 17,900 & 50 & $<0.05$ & $<0.2$ & 42.8 & $<0.02$ & 0.03 & 0.08 & 10 & 0.22 & 3.1 & 0.01 \\
\hline 10HG6 & $<10$ & 35 & $<10$ & 20,700 & 46.8 & $<0.5$ & $<2$ & 39.5 & $<0.2$ & $<0.1$ & $<0.2$ & $<10$ & 0.31 & 5.4 & $<0.05$ \\
\hline 10HG7 & $<10$ & $<20$ & $<10$ & 21,600 & 29.3 & $<0.5$ & $<2$ & 24.7 & $<0.2$ & $<0.1$ & $<0.2$ & $<10$ & 0.21 & $<5$ & $<0.05$ \\
\hline 10HG8 & $<10$ & $<20$ & $<10$ & 17,400 & 56.4 & $<0.5$ & $<2$ & 54.5 & $<0.2$ & $<0.1$ & $<0.2$ & $<10$ & $<0.2$ & $<5$ & $<0.05$ \\
\hline 10HG9 & $<10$ & $<20$ & $<10$ & 13,800 & 49 & $<0.5$ & $<2$ & 76.9 & $<0.2$ & $<0.1$ & $<0.2$ & $<10$ & $<0.2$ & $<5$ & $<0.05$ \\
\hline $10 \mathrm{HG} 10$ & $\begin{array}{l}<10 \\
\text { Low-flow }\end{array}$ & $\begin{array}{l}<20 \\
\text { Sept. } 2010\end{array}$ & $<10$ & 10,900 & 69.1 & $<0.5$ & $<2$ & 69.5 & $<0.2$ & $<0.1$ & $<0.2$ & $<10$ & $<0.2$ & $<5$ & $<0.05$ \\
\hline 10HG4 & $\begin{array}{l}<1 \\
\text { Low-flow }\end{array}$ & $\begin{array}{c}14.8 \\
\text { May } 2011\end{array}$ & 1.6 & 18,900 & 40.6 & $<10$ & $<0.2$ & 39.9 & $<0.02$ & 0.03 & 0.1 & $<1$ & 0.45 & 3.2 & 0.03 \\
\hline 11HG1 & $<1$ & 124 & 1.6 & & 45.3 & $<0.05$ & $\mathrm{nr}$ & 60.7 & $<0.02$ & $<0.01$ & 0.31 & 8 & 0.12 & 4.5 & 0.15 \\
\hline 11HG1.5 & $<1$ & 153 & 5.7 & & 85.9 & $<0.05$ & $\mathrm{nr}$ & 62.7 & $<0.02$ & $<0.01$ & 1.1 & 18.4 & 19.2 & 3.7 & 0.17 \\
\hline 11HG2 & $<1$ & 79.1 & 6.4 & & 89.7 & $<0.05$ & $\mathrm{nr}$ & 58.5 & $<0.02$ & $<0.01$ & 0.68 & 15.5 & 1.4 & 4.8 & 0.17 \\
\hline $11 \mathrm{HG} 3$ & $<1$ & 135 & $<1$ & & 90.8 & $<0.05$ & $\mathrm{nr}$ & 53.4 & $<0.02$ & $<0.01$ & 0.13 & 4.8 & 0.03 & 2.2 & 0.16 \\
\hline 11HG4 & $<1$ & 152 & 3.4 & & 89 & $<0.05$ & $\mathrm{nr}$ & 54 & $<0.02$ & $<0.01$ & 0.34 & 8.5 & 0.51 & 3.5 & 0.18 \\
\hline 11HG5 & $<1$ & 46.7 & 3 & & 88.5 & $<0.05$ & $\mathrm{nr}$ & 57.7 & $<0.02$ & $<0.01$ & 0.18 & 7.8 & 0.26 & 3.1 & 0.17 \\
\hline 11HG6 & $<1$ & 35.7 & 3.2 & & 87.9 & $<0.05$ & $\mathrm{nr}$ & 49.9 & $<0.02$ & $<0.01$ & 0.17 & 5.9 & 0.2 & 3 & 0.16 \\
\hline & High-flow & March 201 & & & & & & & & & & & & & \\
\hline 11HG1 & $<1$ & 35700 & 6.1 & 448 & 488 & 1.1 & $<0.2$ & 35.9 & 0.16 & 34.6 & 102 & 400 & 3.5 & 100 & 3.7 \\
\hline $11 \mathrm{HG} 2$ & $<1$ & 7400 & 3.2 & 3,540 & 161 & 0.22 & $<0.2$ & 25.3 & 0.04 & 6.3 & 14.8 & 72 & 1.7 & 21.5 & 0.67 \\
\hline $11 \mathrm{HG} 3$ & $<1$ & 2280 & $<1$ & 178 & 57.2 & 0.06 & $<0.2$ & 15.2 & $<0.02$ & 1.7 & 2.2 & 12.7 & 0.18 & 6.9 & 0.25 \\
\hline 11HG4 & $<1$ & 3180 & 1.2 & 978 & 75.8 & 0.08 & $<0.2$ & 16.4 & $<0.02$ & 2.8 & 5 & 26 & 0.53 & 9.9 & 0.34 \\
\hline
\end{tabular}




\begin{tabular}{|c|c|c|c|c|c|c|c|c|c|c|c|c|c|c|}
\hline $\begin{array}{c}\text { Field } \\
\text { Number }\end{array}$ & $\begin{array}{c}\text { Er } \\
\text { in } \mu \mathrm{g} / \mathrm{L} \\
\text { Low-flow }\end{array}$ & $\begin{array}{c}\text { Eu } \\
\text { in } \mu \mathrm{g} / \mathrm{L} \\
\text { June } 2010\end{array}$ & $\begin{array}{c}\text { Fe } \\
\text { in } \mu \mathrm{g} / \mathrm{L}\end{array}$ & $\begin{array}{c}\text { Ga } \\
\text { in } \mu g / L\end{array}$ & $\begin{array}{c}\text { Gd } \\
\text { in } \mu \mathrm{g} / \mathrm{L}\end{array}$ & $\begin{array}{c}\text { Ge } \\
\text { in } \mu g / L\end{array}$ & $\begin{array}{c}\text { Ho } \\
\text { in } \mu \mathrm{g} / \mathrm{L}\end{array}$ & $\begin{array}{c}\mathrm{K} \\
\text { in } \mathrm{mg} / \mathrm{L}\end{array}$ & $\begin{array}{c}\mathrm{La} \\
\text { in } \mu \mathrm{g} / \mathrm{L}\end{array}$ & $\begin{array}{c}\text { Li } \\
\text { in } \mu \mathrm{g} / \mathrm{L}\end{array}$ & $\begin{array}{c}\mathrm{Lu} \\
\text { in } \mu \mathrm{g} / \mathrm{L}\end{array}$ & $\begin{array}{c}\mathrm{Mg} \\
\text { in } \mathrm{mg} / \mathrm{L}\end{array}$ & $\begin{array}{c}M n \\
\text { in } \mu g / L\end{array}$ & $\begin{array}{c}\text { Mo } \\
\text { in } \mu \mathrm{g} / \mathrm{L}\end{array}$ \\
\hline 10HG1 & 0.02 & 0.02 & 79.6 & $<0.05$ & 0.04 & 6 & 0.009 & 34.6 & 0.04 & 1,500 & $<0.1$ & 588 & 77.4 & $<2$ \\
\hline 10HG2 & 0.15 & 0.1 & 7210 & 0.83 & 0.36 & 1.4 & 0.052 & 21.9 & 0.89 & 1,090 & $<0.1$ & 553 & 726 & 3.2 \\
\hline 10HG3 & 0.01 & 0.02 & 136 & $<0.05$ & 0.04 & 0.05 & 0.006 & 4.36 & 0.05 & 176 & $<0.1$ & 118 & 11.4 & $<2$ \\
\hline 10HG4 & 0.009 & 0.009 & $<20$ & $<0.05$ & $<0.005$ & 0.05 & $<0.005$ & 9.36 & $<0.01$ & 532 & $<0.1$ & 265 & 24.2 & 2.1 \\
\hline 10HG5 & 0.006 & 0.009 & 23.7 & $<0.05$ & 0.01 & $<0.05$ & $<0.005$ & 10.6 & $<0.01$ & 608 & $<0.1$ & 322 & 6.4 & 2.4 \\
\hline 10HG6 & $<0.05$ & $<0.05$ & 23.8 & $<0.5$ & $<0.05$ & $<0.5$ & $<0.05$ & 12.1 & $<0.1$ & 670 & $<1$ & 294 & 7.9 & $<20$ \\
\hline 10HG7 & $<0.05$ & $<0.05$ & $<20$ & $<0.5$ & $<0.05$ & $<0.5$ & $<0.05$ & 11.1 & $<0.1$ & 677 & $<1$ & 309 & $<2$ & $<20$ \\
\hline 10HG8 & $<0.05$ & $<0.05$ & 21.8 & $<0.5$ & $<0.05$ & $<0.5$ & $<0.05$ & 9.1 & $<0.1$ & 508 & $<1$ & 271 & 23.1 & $<20$ \\
\hline 10HG9 & $<0.05$ & $<0.05$ & $<20$ & $<0.5$ & $<0.05$ & $<0.5$ & $<0.05$ & 7.8 & $<0.1$ & 386 & $<1$ & 213 & $<2$ & $<20$ \\
\hline $10 \mathrm{HG} 10$ & $\begin{array}{l}<0.05 \\
\text { Low-flow }\end{array}$ & $\begin{array}{c}<0.05 \\
\text { Sept. } 2010\end{array}$ & $<20$ & $<0.5$ & $<0.05$ & $<0.5$ & $<0.05$ & 7.22 & $<0.1$ & 330 & $<1$ & 197 & $<2$ & $<20$ \\
\hline 10HG4 & $\begin{array}{l}0.01 \\
\text { Low-flow }\end{array}$ & $\begin{array}{c}0.008 \\
\text { May } 2011\end{array}$ & 62 & 0.06 & 0.02 & & 0.008 & 11.6 & 0.02 & 624 & & 333 & 35.8 & 2.4 \\
\hline 11HG1 & $<0.005$ & 0.04 & $<50$ & $<0.05$ & $<0.005$ & & $<0.005$ & 4.5 & $<0.01$ & 171 & & 291 & 17.6 & $<2$ \\
\hline 11HG1.5 & $<0.005$ & 0.05 & 146 & 0.05 & $<0.005$ & & $<0.005$ & 19.7 & $<0.01$ & 1,090 & & 467 & 136 & $<2$ \\
\hline 11HG2 & $<0.005$ & 0.04 & $<50$ & $<0.05$ & $<0.005$ & & $<0.005$ & 16.4 & $<0.01$ & 919 & & 455 & 27.6 & 2.4 \\
\hline 11HG3 & $<0.005$ & 0.05 & $<50$ & $<0.05$ & $<0.005$ & & $<0.005$ & 2.1 & $<0.01$ & 73.5 & & 142 & 5.1 & $<2$ \\
\hline 11HG4 & $<0.005$ & 0.051 & $<50$ & $<0.05$ & $<0.005$ & & $<0.005$ & 9 & $<0.01$ & 529 & & 274 & 14.4 & $<2$ \\
\hline 11HG5 & $<0.005$ & 0.05 & $<50$ & $<0.05$ & $<0.005$ & & $<0.005$ & 7.7 & $<0.01$ & 461 & & 269 & 7.4 & $<2$ \\
\hline 11HG6 & $\begin{array}{l}<0.005 \\
\text { High-flow }\end{array}$ & $\begin{array}{c}0.04 \\
\text { March } 20\end{array}$ & $<50$ & $<0.05$ & $<0.005$ & & $<0.005$ & 7.8 & $<0.01$ & 476 & & 263 & 5.4 & $<2$ \\
\hline 11HG1 & 1.7 & 1.2 & 65,800 & 15.8 & 4.7 & & 0.68 & 7.3 & 12.3 & 116 & & 115 & 1740 & $<2$ \\
\hline 11HG2 & 0.34 & 0.23 & 12,700 & 3.1 & 0.85 & & 0.12 & 6 & 2.1 & 170 & & 92.9 & 263 & $<2$ \\
\hline 11HG3 & 0.15 & 0.094 & 3,240 & 0.87 & 0.34 & & 0.05 & 1.7 & 0.68 & 22.5 & & 27.4 & 59 & $<2$ \\
\hline 11HG4 & 0.2 & 0.14 & 5,200 & 1.4 & 0.41 & & 0.067 & 2.7 & 1 & 55.6 & & 40.6 & 103 & $<2$ \\
\hline
\end{tabular}




\begin{tabular}{|c|c|c|c|c|c|c|c|c|c|c|c|c|c|c|c|}
\hline $\begin{array}{c}\text { Field } \\
\text { Number }\end{array}$ & $\begin{array}{c}\mathrm{Na} \\
\text { in } \mathrm{mg} / \mathrm{L} \\
\text { Low-flow }\end{array}$ & $\begin{array}{c}\mathrm{Nb} \\
\text { in } \mu \mathrm{g} / \mathrm{L} \\
\text { June } 2010\end{array}$ & $\begin{array}{c}\text { Nd } \\
\text { in } \mu g / L\end{array}$ & $\begin{array}{c}\mathrm{Ni} \\
\text { in } \mu \mathrm{g} / \mathrm{L}\end{array}$ & $\begin{array}{c}P \\
\text { in } \mathrm{mg} / \mathrm{L}\end{array}$ & $\begin{array}{c}\mathrm{Pb} \\
\text { in } \mu \mathrm{g} / \mathrm{L}\end{array}$ & $\begin{array}{c}\mathrm{Pr} \\
\text { in } \mu \mathrm{g} / \mathrm{L}\end{array}$ & $\begin{array}{c}\mathrm{Rb} \\
\text { in } \mu \mathrm{g} / \mathrm{L}\end{array}$ & $\begin{array}{c}\text { Sb } \\
\text { in } \mu g / L\end{array}$ & $\begin{array}{c}\text { Sc } \\
\text { in } \mu g / L\end{array}$ & $\begin{array}{c}\text { Se } \\
\text { in } \mu g / L\end{array}$ & $\begin{array}{c}\mathrm{SiO2} \\
\text { in mg/L }\end{array}$ & $\begin{array}{c}\text { Sm } \\
\text { in } \mu g / L\end{array}$ & $\begin{array}{c}\text { SO4 } \\
\text { in mg/L }\end{array}$ & $\begin{array}{c}\mathrm{Sr} \\
\text { in } \mu \mathrm{g} / \mathrm{L}\end{array}$ \\
\hline 10HG1 & 1,030 & $<0.2$ & 0.07 & 6.5 & 0.2 & 1.7 & 0.01 & 65.5 & 0.83 & 4.5 & 22.9 & 58.7 & 0.02 & 1,310 & 2,250 \\
\hline 10HG2 & 828 & $<0.2$ & 1.36 & 92.4 & 0.5 & 2.5 & 0.29 & 9.93 & 0.45 & 3.8 & 18.9 & 48 & 0.32 & 1,400 & 1,850 \\
\hline 10HG3 & 97.6 & $<0.2$ & 0.09 & $<0.4$ & $<0.01$ & 1.6 & 0.02 & 2.42 & $<0.3$ & 1.6 & 1.8 & 18.1 & 0.02 & 336 & 908 \\
\hline 10HG4 & 419 & $<0.2$ & 0.02 & 0.6 & $<0.01$ & 2 & $<0.01$ & 7.56 & 0.46 & 1.6 & 8.7 & 20.3 & $<0.01$ & 838 & 1,170 \\
\hline 10HG5 & 509 & $<0.2$ & 0.01 & 1.1 & $<0.01$ & 1.9 & $<0.01$ & 8.36 & 0.49 & 1.5 & 10.9 & 20 & $<0.01$ & 962 & 1,190 \\
\hline 10HG6 & 542 & $<2$ & $<0.1$ & $<4$ & $<0.1$ & $<0.5$ & $<0.1$ & 7.52 & $<3$ & $<6$ & $<10$ & 14.2 & $<0.1$ & 904 & 1,020 \\
\hline 10HG7 & 562 & $<2$ & $<0.1$ & $<4$ & $<0.1$ & $<0.5$ & $<0.1$ & 7.1 & $<3$ & $<6$ & $<10$ & 13.4 & $<0.1$ & 977 & 516 \\
\hline 10HG8 & 457 & $<2$ & $<0.1$ & $<4$ & $<0.1$ & $<0.5$ & $<0.1$ & 2.93 & $<3$ & $<6$ & $<10$ & 14.2 & $<0.1$ & 890 & 1,150 \\
\hline 10HG9 & 355 & $<2$ & $<0.1$ & $<4$ & $<0.1$ & $<0.5$ & $<0.1$ & 3.01 & $<3$ & $<6$ & $<10$ & 12.2 & $<0.1$ & 790 & 1,300 \\
\hline $10 \mathrm{HG} 10$ & $\begin{array}{l}345 \\
\text { Low-flow }\end{array}$ & $\begin{array}{c}<2 \\
\text { June } 2010\end{array}$ & $<0.1$ & $<4$ & $<0.1$ & $<0.5$ & $<0.1$ & 1.59 & $<3$ & $<6$ & $<10$ & 9.6 & $<0.1$ & 776 & 1,340 \\
\hline 10HG4 & $\begin{array}{l}561 \\
\text { Low-flow }\end{array}$ & $\begin{array}{c}<0.2 \\
\text { May } 2011\end{array}$ & 0.03 & $<0.4$ & 0.2 & $<0.05$ & $<0.01$ & 10.5 & 0.65 & 1.4 & 63.5 & 20 & 0.04 & 1,000 & 1,220 \\
\hline 11HG1 & $\mathrm{nr}$ & $<0.2$ & $<0.01$ & 11.5 & 0.1 & $<0.05$ & $<0.01$ & 2.1 & 1 & 1.8 & 1.7 & 20 & $<0.01$ & 900 & 887 \\
\hline 11HG1.5 & $\mathrm{nr}$ & $<0.2$ & $<0.01$ & 12.4 & 0.2 & $<0.05$ & $<0.01$ & 29 & 1.1 & 4 & 14.7 & 43 & $<0.01$ & 1,100 & 1,940 \\
\hline 11HG2 & $\mathrm{nr}$ & $<0.2$ & $<0.01$ & 14.3 & 0.2 & $<0.05$ & $<0.01$ & 8.2 & 1.7 & 2.2 & 15.7 & 27 & $<0.01$ & 1,100 & 1,690 \\
\hline $11 \mathrm{HG} 3$ & 66.8 & $<0.2$ & $<0.01$ & $<0.4$ & 0.04 & $<0.05$ & $<0.01$ & 1.1 & $<0.3$ & 1.7 & 1.5 & 20 & $<0.01$ & 190 & 850 \\
\hline $11 \mathrm{HG} 4$ & $\mathrm{nr}$ & $<0.2$ & $<0.01$ & 6.1 & 0.09 & $<0.05$ & $<0.01$ & 4.4 & 0.85 & 1.8 & 8.3 & 21 & $<0.01$ & 630 & 1,170 \\
\hline 11HG5 & $\mathrm{nr}$ & $<0.2$ & $<0.01$ & 4.1 & 0.07 & $<0.05$ & $<0.01$ & 3.7 & 0.76 & 1.9 & 7.2 & 22 & $<0.01$ & 590 & 1,180 \\
\hline 11HG6 & $\begin{array}{l}\mathrm{nr} \\
\text { High-flow }\end{array}$ & $\begin{array}{c}<0.2 \\
\text { March } 201\end{array}$ & $\begin{array}{l}<0.01 \\
1\end{array}$ & 3.6 & 0.07 & $<0.05$ & $<0.01$ & 3.4 & 0.8 & 1.6 & 7.1 & 19 & $<0.01$ & 600 & 1,030 \\
\hline 11HG1 & 26.7 & $<0.2$ & 18.6 & 1560 & 0.4 & 19.2 & 4.3 & 25 & 0.52 & 37.8 & $<1$ & 240 & 4.7 & 200 & 435 \\
\hline 11HG2 & 103 & $<0.2$ & 3.3 & 233 & 0.2 & 3.27 & 0.78 & 8.8 & 0.63 & 9.9 & 2.3 & 79 & 0.79 & 270 & 440 \\
\hline 11HG3 & 11.2 & $<0.2$ & 1.1 & 28 & 0.08 & 0.75 & 0.28 & 2.3 & $<0.3$ & 3.1 & $<1$ & 27 & 0.23 & 25 & 170 \\
\hline 11HG4 & 32 & $<0.2$ & 1.6 & 76 & 0.1 & 1.28 & 0.38 & 3.8 & $<0.3$ & 4.8 & 1.3 & 37 & 0.39 & 80 & 238 \\
\hline
\end{tabular}


Table 6 (cont'd)

\begin{tabular}{|c|c|c|c|c|c|c|c|c|c|c|c|c|c|}
\hline $\begin{array}{c}\text { Field } \\
\text { Number }\end{array}$ & $\begin{array}{c}\mathrm{Ta} \\
\text { in } \mu \mathrm{g} / \mathrm{L} \\
\text { Low-flow }\end{array}$ & $\begin{array}{c}\text { Tb } \\
\text { in } \mu \mathrm{g} / \mathrm{L} \\
\text { June } 2010\end{array}$ & $\begin{array}{c}\text { Th } \\
\text { in } \mu g / L\end{array}$ & $\begin{array}{c}\mathrm{Ti} \\
\text { in } \mu \mathrm{g} / \mathrm{L}\end{array}$ & $\begin{array}{c}\text { Tl } \\
\text { in } \mu g / L\end{array}$ & $\begin{array}{c}\text { Tm } \\
\text { in } \mu g / L\end{array}$ & $\begin{array}{c}U \\
\text { in } \mu g / L\end{array}$ & $\begin{array}{c}V \\
\text { in } \mu \mathrm{g} / \mathrm{L}\end{array}$ & $\begin{array}{c}\text { W } \\
\text { in } \mu g / L\end{array}$ & $\begin{array}{c}Y \\
\text { in } \mu g / L\end{array}$ & $\begin{array}{c}Y b \\
\text { in } \mu g / L\end{array}$ & $\begin{array}{c}\mathrm{Zn} \\
\text { in } \mu \mathrm{g} / \mathrm{L}\end{array}$ & $\begin{array}{c}\mathrm{Zr} \\
\text { in } \mu \mathrm{g} / \mathrm{L}\end{array}$ \\
\hline 10HG1 & 0.04 & $<0.005$ & $<0.2$ & 20.4 & 0.1 & $<0.005$ & 0.91 & 9.6 & 261 & 0.33 & 0.02 & 22.4 & $<0.2$ \\
\hline 10HG2 & 0.06 & 0.055 & 0.2 & 44.1 & $<0.1$ & 0.02 & 2.69 & 14.6 & 26.8 & 1.37 & $\begin{array}{l}0.08 \\
<\end{array}$ & 28.6 & 0.7 \\
\hline 10HG3 & 0.02 & 0.006 & $<0.2$ & 6.4 & $<0.1$ & $<0.005$ & 0.71 & 4.3 & 1.82 & 0.17 & 0.005 & 1.7 & $<0.2$ \\
\hline 10HG4 & 0.02 & $<0.005$ & $<0.2$ & 13.3 & $<0.1$ & $<0.005$ & 1.7 & 5.2 & 7.06 & 0.08 & 0.007 & 3.2 & $<0.2$ \\
\hline 10HG5 & 0.02 & $<0.005$ & $<0.2$ & 15.5 & $<0.1$ & $<0.005$ & 2.12 & 5.7 & 8.5 & 0.09 & 0.008 & 4.4 & $<0.2$ \\
\hline 10HG6 & $<0.2$ & $<0.05$ & $<2$ & 10.6 & $<1$ & $<0.05$ & $<1$ & $<5$ & 48.5 & $<0.1$ & $<0.05$ & 495 & $<2$ \\
\hline 10HG7 & $<0.2$ & $<0.05$ & $<2$ & 10.6 & $<1$ & $<0.05$ & $<1$ & $<5$ & 25.3 & $<0.1$ & $<0.05$ & $<5$ & $<2$ \\
\hline 10HG8 & $<0.2$ & $<0.05$ & $<2$ & 10.2 & $<1$ & $<0.05$ & $<1$ & $<5$ & 14.4 & $<0.1$ & $<0.05$ & $<5$ & $<2$ \\
\hline 10HG9 & $<0.2$ & $<0.05$ & $<2$ & 7.2 & $<1$ & $<0.05$ & $<1$ & $<5$ & 11.3 & $<0.1$ & $<0.05$ & $<5$ & $<2$ \\
\hline $10 \mathrm{HG} 10$ & $\begin{array}{l}<0.2 \\
\text { Low-flow }\end{array}$ & $\begin{array}{l}<0.05 \\
\text { Sept. } 2010\end{array}$ & $<2$ & 9.5 & $<1$ & $<0.05$ & $<1$ & $<5$ & 8.24 & $<0.1$ & $<0.05$ & $<5$ & $<2$ \\
\hline 10HG4 & $\begin{array}{l}0.1 \\
\text { Low-flow }\end{array}$ & $\begin{array}{c}<0.005 \\
\text { May } 2011\end{array}$ & $<0.2$ & 25.3 & $<0.1$ & 0.007 & 2.32 & 1.8 & & 0.07 & 0.02 & $<3$ & \\
\hline 11HG1 & 0.29 & $<0.005$ & 0.4 & 18.2 & $<0.1$ & $<0.005$ & 1.39 & 4.6 & 1.5 & 0.11 & $<0.01$ & 19 & \\
\hline 11HG1.5 & 0.3 & $<0.005$ & 0.41 & 19.8 & $<0.1$ & $<0.005$ & 1.55 & 8.5 & 110 & 0.22 & $<0.01$ & 10.8 & \\
\hline 11HG2 & 0.29 & $<0.005$ & 0.39 & 18.7 & $<0.1$ & $<0.005$ & 2.55 & 9.9 & 35 & 0.23 & $<0.01$ & 16.1 & \\
\hline 11HG3 & 0.28 & $<0.005$ & 0.36 & 5.3 & $<0.1$ & $<0.005$ & 1.05 & 3.7 & 1.6 & 0.17 & $<0.01$ & $<3$ & \\
\hline 11HG4 & 0.28 & $<0.005$ & 0.37 & 12.5 & $<0.1$ & $<0.005$ & 1.67 & 6.2 & 15 & 0.22 & $<0.01$ & 8.2 & \\
\hline 11HG5 & 0.28 & $<0.005$ & 0.36 & 10.6 & $<0.1$ & $<0.005$ & 1.77 & 5.9 & 11 & 0.18 & $<0.01$ & 4.9 & \\
\hline 11HG6 & 0.28 & $<0.005$ & 0.37 & 10.7 & $<0.1$ & $<0.005$ & 1.68 & 5.3 & 12 & 0.14 & $<0.01$ & 3.3 & \\
\hline & High-flov & March 201 & & & & & & & & & & & \\
\hline $11 \mathrm{HG} 1$ & $<0.02$ & 0.71 & 3.41 & 66.3 & 1.31 & 0.25 & 0.77 & 141 & 0.72 & 17.4 & 1.2 & 234 & 234 \\
\hline 11HG2 & $<0.02$ & 0.14 & 0.81 & 74.3 & 0.26 & 0.075 & 0.48 & 32.2 & 2 & 3.1 & 0.25 & 50 & 50 \\
\hline 11HG3 & $<0.02$ & 0.064 & 0.26 & 22.2 & $<0.1$ & 0.05 & 0.13 & 12.2 & $<0.5$ & 1.1 & 0.08 & 13.4 & 13.4 \\
\hline 11HG4 & $<0.02$ & 0.078 & 0.35 & 31.6 & 0.12 & 0.051 & 0.21 & 16.5 & 0.5 & 1.5 & 0.12 & 20.4 & 20.4 \\
\hline
\end{tabular}


Table 7. Filtered water, major and minor element concentrations from ICP-MS (ICP-AES for major elements), Harley Gulch, Lake County, California.

\begin{tabular}{|c|c|c|c|c|c|c|c|c|c|c|c|c|c|}
\hline $\begin{array}{c}\text { Field } \\
\text { number }\end{array}$ & $\begin{array}{c}\mathrm{Ag} \\
\text { in } \mu \mathrm{g} / \mathrm{L} \\
\text { Low-flow }\end{array}$ & $\begin{array}{c}\text { Al } \\
\text { in } \mu \mathrm{g} / \mathrm{L} \\
\text { June } 2010\end{array}$ & $\begin{array}{c}\text { As } \\
\text { in } \mu \mathrm{g} / \mathrm{L}\end{array}$ & $\begin{array}{c}\text { B } \\
\text { in } \mu \mathrm{g} / \mathrm{L}\end{array}$ & $\begin{array}{c}\mathrm{Ba} \\
\text { in } \mu \mathrm{g} / \mathrm{L}\end{array}$ & $\begin{array}{c}\mathrm{Be} \\
\text { in } \mu \mathrm{g} / \mathrm{L}\end{array}$ & $\begin{array}{c}B i \\
\text { in } \mu g / L\end{array}$ & $\begin{array}{c}\mathrm{Ca} \\
\text { in } \mathrm{mg} / \mathrm{L}\end{array}$ & $\begin{array}{c}\mathrm{Cd} \\
\text { in } \mu \mathrm{g} / \mathrm{L}\end{array}$ & $\begin{array}{c}\mathrm{Ce} \\
\text { in } \mu \mathrm{g} / \mathrm{L}\end{array}$ & $\begin{array}{c}\text { Co } \\
\text { in } \mu \mathrm{g} / \mathrm{L}\end{array}$ & $\begin{array}{c}\mathrm{Cr} \\
\text { in } \mu \mathrm{g} / \mathrm{L}\end{array}$ & $\begin{array}{c}\text { Cs } \\
\text { in } \mu \mathrm{g} / \mathrm{L}\end{array}$ \\
\hline 10HG1 & $<1$ & 7.6 & 8.3 & 42,500 & 80.7 & $<0.05$ & $<0.2$ & 42.8 & $<0.02$ & 0.09 & 0.6 & 19.9 & 34.8 \\
\hline 10HG2 & $<1$ & 6.4 & 12.8 & 33,300 & 126 & $<0.05$ & $<0.2$ & 50.8 & $<0.02$ & 0.03 & 2.03 & 17.7 & 0.14 \\
\hline 10HG3 & $<1$ & $<2$ & 1 & 2,410 & 88.3 & $<0.05$ & $<0.2$ & 53.1 & $<0.02$ & 0.04 & 0.08 & 4.9 & $<0.02$ \\
\hline 10HG4 & $<1$ & $<2$ & 3.8 & 14,800 & 52.7 & $<0.05$ & $<0.2$ & 46.7 & $<0.02$ & 0.01 & 0.09 & 9.6 & 0.2 \\
\hline 10HG5 & $<1$ & 2.8 & 4.6 & 18,200 & 51.2 & $<0.05$ & $<0.2$ & 43.8 & $<0.02$ & 0.02 & 0.08 & 10 & 0.22 \\
\hline 10HG6 & $<10$ & $<20$ & $<10$ & 21,100 & 48.1 & $<0.5$ & $<2$ & $<20$ & $<0.2$ & $<0.1$ & $<0.2$ & $<10$ & 0.35 \\
\hline 10HG7 & $<10$ & $<20$ & $<10$ & 21,800 & 28 & $<0.5$ & $<2$ & $<20$ & $<0.2$ & $<0.1$ & 0.2 & $<10$ & 0.25 \\
\hline 10HG8 & $<10$ & $<20$ & $<10$ & 16,900 & 58.6 & $<0.5$ & $<2$ & $<20$ & $<0.2$ & $<0.1$ & $<0.2$ & $<10$ & $<0.2$ \\
\hline 10HG9 & $<10$ & $<20$ & $<10$ & 13,900 & 48.6 & $<0.5$ & $<2$ & $<20$ & $<0.2$ & $<0.1$ & $<0.2$ & $<10$ & $<0.2$ \\
\hline 10HG10 & & $<0.2$ \\
\hline 10HG4-2 & $\begin{array}{l}\text { Low-flow } \\
<1 \\
\text { Low-flow }\end{array}$ & $\begin{array}{l}\text { Sept. } 2010 \\
<2 \\
\text { May } 2011\end{array}$ & 5 & 20,600 & 54.3 & $\mathrm{nr}$ & $<0.2$ & 43.3 & 0.05 & 0.02 & 0.08 & 1.2 & 0.77 \\
\hline 11HG1-2 & $<1$ & 3 & 1.3 & & 39.6 & $<0.05$ & $\mathrm{nr}$ & 59 & $<0.02$ & $<0.01$ & 0.31 & 4.2 & 0.08 \\
\hline 11HG1.5-2 & $<1$ & 3 & 5.4 & & 79.5 & $<0.05$ & $\mathrm{nr}$ & 59.8 & $<0.02$ & $<0.01$ & 0.27 & 14.6 & 18.7 \\
\hline 11HG2-2 & $<1$ & 2.7 & 6.6 & & 84.9 & $<0.05$ & $\mathrm{nr}$ & 58.1 & $<0.02$ & $<0.01$ & 0.6 & 12.1 & 1.3 \\
\hline 11HG3-2 & $<1$ & 6.4 & $<1$ & & 89.7 & $<0.05$ & $\mathrm{nr}$ & 53.9 & $<0.02$ & $<0.01$ & 0.25 & 6.2 & $<0.02$ \\
\hline 11HG4-2 & $<1$ & 7 & 3.2 & & 86.3 & $<0.05$ & $\mathrm{nr}$ & 53.5 & $<0.02$ & $<0.01$ & 0.53 & 7.9 & 0.47 \\
\hline 11HG5-2 & $<1$ & 11 & 3.2 & & 86 & $<0.05$ & $\mathrm{nr}$ & 55.8 & $<0.02$ & $<0.01$ & 0.15 & 7.2 & 0.24 \\
\hline 11HG6-2 & $<1$ & 20.7 & 3.1 & & 87.6 & $<0.05$ & $\mathrm{nr}$ & 50.4 & $<0.02$ & $<0.01$ & 0.17 & 5.3 & 0.2 \\
\hline & \multicolumn{13}{|c|}{ High-flow March 2011} \\
\hline 11HG1 & $<1$ & 176 & $<1$ & 476 & 72.2 & $<0.05$ & $<0.2$ & 29 & $<0.02$ & 0.24 & 4.5 & 3.3 & 0.06 \\
\hline 11HG2 & $<1$ & 49.5 & 1.5 & 3,400 & 61.1 & $<0.05$ & $<0.2$ & 23 & $<0.02$ & 0.13 & 3.2 & 2.4 & 0.04 \\
\hline $11 \mathrm{HG} 3$ & $<1$ & 59.5 & $<1$ & 196 & 30.1 & $<0.05$ & $<0.2$ & 15.7 & $<0.02$ & 0.15 & 0.13 & 1.6 & $<0.02$ \\
\hline 11HG4 & $<1$ & 399 & $<1$ & 1,340 & 44.1 & $<0.05$ & $<0.2$ & 17.9 & $<0.02$ & 0.38 & 0.67 & 4.5 & 0.11 \\
\hline
\end{tabular}


Table 7 (cont'd)

\begin{tabular}{|c|c|c|c|c|c|c|c|c|c|c|c|c|c|}
\hline $\begin{array}{c}\text { Field } \\
\text { number }\end{array}$ & $\begin{array}{c}\mathrm{Cu} \\
\text { in } \mu \mathrm{g} / \mathrm{L} \\
\text { Low-flo }\end{array}$ & $\begin{array}{c}\text { Dy } \\
\text { in } \mu \mathrm{g} / \mathrm{L} \\
\text { June } 201\end{array}$ & $\begin{array}{c}\text { Er } \\
\text { in } \mu g / L\end{array}$ & $\begin{array}{c}\text { Eu } \\
\text { in } \mu g / L\end{array}$ & $\begin{array}{c}\mathrm{Fe} \\
\text { in } \mu \mathrm{g} / \mathrm{L}\end{array}$ & $\begin{array}{c}\text { Ga } \\
\text { in } \mu g / L\end{array}$ & $\begin{array}{c}\text { Gd } \\
\text { in } \mu g / L\end{array}$ & $\begin{array}{c}\text { Ge } \\
\text { in } \mu g / L\end{array}$ & $\begin{array}{c}\text { Ho } \\
\text { in } \mu \mathrm{g} / \mathrm{L}\end{array}$ & $\begin{array}{c}\mathrm{K} \\
\text { in } \mathrm{mg} / \mathrm{L}\end{array}$ & $\begin{array}{c}\text { La } \\
\text { in } \mu g / L\end{array}$ & $\begin{array}{c}\mathrm{Li} \\
\text { in } \mu \mathrm{g} / \mathrm{L}\end{array}$ & $\begin{array}{c}\mathrm{Lu} \\
\text { in } \mu \mathrm{g} / \mathrm{L}\end{array}$ \\
\hline 10HG1 & 3.6 & 0.03 & 0.02 & 0.01 & $<20$ & $<0.05$ & 0.01 & 5.5 & 0.008 & 34.1 & 0.02 & 1,520 & $<0.1$ \\
\hline 10HG3 & 1.8 & 0.01 & 0.01 & 0.01 & $<20$ & $<0.05$ & 0.02 & $<0.05$ & $<0.005$ & 4.41 & 0.02 & 171 & $<0.1$ \\
\hline 10HG4 & 2.7 & $<0.005$ & 0.005 & 0.005 & $<20$ & $<0.05$ & 0.005 & $<0.05$ & $<0.005$ & 9.35 & $<0.01$ & 522 & $<0.1$ \\
\hline 10HG5 & 3 & 0.005 & 0.007 & $<0.005$ & $<20$ & $<0.05$ & 0.009 & $<0.05$ & $<0.005$ & 10.8 & $<0.01$ & 626 & $<0.1$ \\
\hline 10HG6 & $<5$ & $<0.05$ & $<0.05$ & $<0.05$ & $<20$ & $<0.5$ & $<0.05$ & $<0.5$ & $<0.05$ & 12.6 & $<0.1$ & 657 & $<1$ \\
\hline 10HG7 & $<5$ & $<0.05$ & $<0.05$ & $<0.05$ & $<20$ & $<0.5$ & $<0.05$ & $<0.5$ & $<0.05$ & 11.1 & $<0.1$ & 663 & $<1$ \\
\hline 10HG8 & $<5$ & $<0.05$ & $<0.05$ & $<0.05$ & $<20$ & $<0.5$ & $<0.05$ & $<0.5$ & $<0.05$ & 8.6 & $<0.1$ & 484 & $<1$ \\
\hline 10HG9 & $<5$ & $<0.05$ & $<0.05$ & $<0.05$ & $<20$ & $<0.5$ & $<0.05$ & $<0.5$ & $<0.05$ & 6.76 & $<0.1$ & 381 & $<1$ \\
\hline 10HG10 & $\begin{array}{l}<5 \\
\text { Low-flo }\end{array}$ & $\begin{array}{l}<0.05 \\
\text { Sept. } 20\end{array}$ & $<0.05$ & $<0.05$ & $<20$ & $<0.5$ & $<0.05$ & $<0.5$ & $<0.05$ & 5.78 & $<0.1$ & 339 & $<1$ \\
\hline 10HG4-2 & $\begin{array}{l}2.2 \\
\text { Low-flo }\end{array}$ & $\begin{array}{l}0.01 \\
\text { May } 201\end{array}$ & 0.04 & 0.02 & 43 & 0.1 & 0.01 & & 0.005 & 12.8 & 0.01 & 678 & \\
\hline 11HG1-2 & 3.5 & 0.15 & $<0.005$ & 0.04 & $<50$ & $<0.05$ & $<0.005$ & & $<0.005$ & 4.4 & $<0.01$ & 166 & \\
\hline 11HG2-2 & 4.3 & 0.16 & $<0.005$ & 0.04 & $<50$ & $<0.05$ & $<0.005$ & & $<0.005$ & 16 & $<0.01$ & 934 & \\
\hline 11HG3-2 & 2 & 0.16 & $<0.005$ & 0.05 & $<50$ & $<0.05$ & $<0.005$ & & $<0.005$ & 2.2 & $<0.01$ & 76.7 & \\
\hline 11HG4-2 & 3.2 & 0.17 & $<0.005$ & 0.05 & $<50$ & $<0.05$ & $<0.005$ & & $<0.005$ & 8.6 & $<0.01$ & 530 & \\
\hline 11HG5-2 & 3 & 0.16 & $<0.005$ & 0.05 & $<50$ & $<0.05$ & $<0.005$ & & $<0.005$ & 7.5 & $<0.01$ & 462 & \\
\hline 11HG6-2 & $\begin{array}{l}3.2 \\
\text { High-flo }\end{array}$ & $\begin{array}{l}0.17 \\
\text { March } 2\end{array}$ & $\begin{array}{l}<0.005 \\
11\end{array}$ & 0.05 & $<50$ & $<0.05$ & $<0.005$ & & $<0.005$ & 7.9 & $<0.01$ & 503 & \\
\hline 11HG1 & 3 & 0.072 & 0.07 & 0.04 & 327 & 0.06 & 0.077 & & 0.01 & 2 & 0.09 & 27.1 & \\
\hline 11HG2 & 3.3 & 0.065 & 0.063 & 0.03 & 62.7 & $<0.05$ & 0.063 & & 0.01 & 4.5 & 0.05 & 127 & \\
\hline 11HG3 & 2.9 & 0.076 & 0.064 & 0.04 & 114 & $<0.05$ & 0.082 & & 0.01 & 1.3 & 0.06 & 8.9 & \\
\hline 11HG4 & 3.7 & 0.11 & 0.072 & 0.04 & 646 & 0.2 & 0.1 & & 0.02 & 2.4 & 0.14 & 51.5 & \\
\hline
\end{tabular}


Table 7 (cont'd)

\begin{tabular}{|c|c|c|c|c|c|c|c|c|c|c|c|c|c|}
\hline $\begin{array}{c}\text { Field } \\
\text { number }\end{array}$ & $\begin{array}{l}\mathrm{Mg} \\
\text { in } \mathrm{mg} / \mathrm{L} \\
\text { Low-flov }\end{array}$ & $\begin{array}{c}\text { Mn } \\
\text { in } \mu \mathrm{g} / \mathrm{L} \\
\mathrm{v} \text { June } 2010\end{array}$ & $\begin{array}{c}\text { Mo } \\
\text { in } \mu \mathrm{g} / \mathrm{L}\end{array}$ & $\begin{array}{c}\mathrm{Na} \\
\text { in } \mathrm{mg} / \mathrm{L}\end{array}$ & $\begin{array}{c}\mathrm{Nb} \\
\text { in } \mu \mathrm{g} / \mathrm{L}\end{array}$ & $\begin{array}{c}\text { Nd } \\
\text { in } \mu g / L\end{array}$ & $\begin{array}{c}\mathrm{Ni} \\
\text { in } \mu \mathrm{g} / \mathrm{L}\end{array}$ & $\begin{array}{c}P \\
\text { in } \mathrm{mg} / \mathrm{L}\end{array}$ & $\begin{array}{c}\mathrm{Pb} \\
\text { in } \mu \mathrm{g} / \mathrm{L}\end{array}$ & $\begin{array}{c}\mathrm{Pr} \\
\text { in } \mu \mathrm{g} / \mathrm{L}\end{array}$ & $\begin{array}{c}\mathrm{Rb} \\
\text { in } \mu \mathrm{g} / \mathrm{L}\end{array}$ & $\begin{array}{c}\text { Sb } \\
\text { in } \mu g / L\end{array}$ & $\begin{array}{c}\text { Sc } \\
\text { in } \mu g / L\end{array}$ \\
\hline $10 \mathrm{HG} 1$ & 617 & 75.5 & $<2$ & 1080 & $<0.2$ & 0.06 & 5.4 & 0.07 & 1 & $<0.01$ & 65.6 & 0.8 & 4.1 \\
\hline 10HG2 & 552 & 210 & 3.6 & 855 & $<0.2$ & 0.02 & 11.3 & 0.2 & 0.8 & $<0.01$ & 7.81 & 0.35 & 2.2 \\
\hline 10HG3 & 119 & 7.4 & $<2$ & 101 & $<0.2$ & 0.03 & $<0.4$ & $<0.01$ & 1.3 & $<0.01$ & 2.36 & $<0.3$ & 1.5 \\
\hline 10HG4 & 276 & 24.6 & 2 & 430 & $<0.2$ & $<0.01$ & $<0.4$ & $<0.01$ & 1.6 & $<0.01$ & 7.43 & 0.45 & 1.6 \\
\hline 10HG5 & 330 & 4.3 & 2.4 & 522 & $<0.2$ & 0.01 & 0.8 & $<0.01$ & 1.6 & $<0.01$ & 8.69 & 0.49 & 1.5 \\
\hline 10HG6 & 302 & $<2$ & $<20$ & 557 & $<2$ & $<0.1$ & $<4$ & $<0.1$ & $<0.5$ & $<0.1$ & 7.45 & $<3$ & $<6$ \\
\hline 10HG7 & 309 & $<2$ & $<20$ & 573 & $<2$ & $<0.1$ & $<4$ & $<0.1$ & $<0.5$ & $<0.1$ & 7.02 & $<3$ & $<6$ \\
\hline 10HG8 & 269 & 19.5 & $<20$ & 439 & $<2$ & $<0.1$ & $<4$ & $<0.1$ & $<0.5$ & $<0.1$ & 2.78 & $<3$ & $<6$ \\
\hline 10HG9 & 211 & $<2$ & $<20$ & 372 & $<2$ & $<0.1$ & $<4$ & $<0.1$ & $<0.5$ & $<0.1$ & 2.97 & $<3$ & $<6$ \\
\hline $10 \mathrm{HG} 10$ & 202 & $<2$ & $<20$ & 343 & $<2$ & $<0.1$ & $<4$ & $<0.1$ & $<0.5$ & $<0.1$ & 1.65 & $<3$ & $<6$ \\
\hline 10HG4-2 & $\begin{array}{l}\text { Low-flov } \\
360 \\
\text { Low-flov }\end{array}$ & $\begin{array}{l}\text { Sept. 201 } \\
27.2 \\
\text { vay } 2011\end{array}$ & 2.5 & 612 & $<0.2$ & 0.04 & 0.5 & 0.1 & $<0.05$ & $<0.01$ & 10.5 & 1.1 & 2.4 \\
\hline 11HG1-2 & 296 & 10.7 & $<2$ & $\mathrm{nr}$ & $<0.2$ & $<0.01$ & 8.9 & 0.1 & $<0.05$ & $<0.01$ & 1.9 & 0.95 & 1.5 \\
\hline 11HG2-2 & 442 & 17.7 & 2.3 & $\mathrm{nr}$ & $<0.2$ & $<0.01$ & 11.4 & 0.2 & $<0.05$ & $<0.01$ & 7.9 & 1.7 & 2.1 \\
\hline $11 \mathrm{HG} 3-2$ & 146 & 3.1 & $<2$ & 70.9 & $<0.2$ & $<0.01$ & $<0.4$ & 0.04 & $<0.05$ & $<0.01$ & 1.1 & $<0.3$ & 1.6 \\
\hline 11HG4-2 & 279 & 9.6 & $<2$ & $\mathrm{nr}$ & $<0.2$ & $<0.01$ & 5.4 & 0.1 & $<0.05$ & $<0.01$ & 4.2 & 0.9 & 1.7 \\
\hline $11 \mathrm{HG} 5-2$ & 262 & 5.5 & $<2$ & $\mathrm{nr}$ & $<0.2$ & $<0.01$ & 4 & 0.08 & $<0.05$ & $<0.01$ & 3.6 & 0.71 & 1.8 \\
\hline 11HG6-2 & 269 & 3.1 & $<2$ & $\mathrm{nr}$ & $<0.2$ & $<0.01$ & 3.5 & 0.07 & $<0.05$ & $<0.01$ & 3.4 & 0.76 & 1.5 \\
\hline & High-flo & $N$ March 20 & & & & & & & & & & & \\
\hline 11HG1 & 61.5 & 12.8 & $<2$ & 28.1 & $<0.2$ & 0.23 & 10.8 & 0.06 & 0.3 & 0.06 & 0.5 & 0.46 & 1.8 \\
\hline 11HG2 & 80.1 & 7.3 & $<2$ & 101 & $<0.2$ & 0.18 & 6.7 & 0.07 & 0.27 & 0.05 & 1.5 & 1.5 & 1.9 \\
\hline 11HG3 & 27.5 & 4.9 & $<2$ & 12.1 & $<0.2$ & 0.2 & 3.3 & 0.05 & $<0.05$ & 0.05 & 0.22 & $<0.3$ & 1.7 \\
\hline 11HG4 & 45.5 & 12.9 & $<2$ & 41 & $<0.2$ & 0.34 & 12.7 & 0.06 & 0.17 & 0.08 & 0.94 & $<0.3$ & 2 \\
\hline
\end{tabular}


Table 7(cont'd)

\begin{tabular}{|c|c|c|c|c|c|c|c|c|c|c|c|c|c|}
\hline $\begin{array}{c}\text { Field } \\
\text { number }\end{array}$ & $\begin{array}{c}\text { Se } \\
\text { in } \mu \mathrm{g} / \mathrm{L} \\
\text { Low-flow }\end{array}$ & $\begin{array}{c}\mathrm{SiO2} \\
\text { in mg/L } \\
\text { June } 2010\end{array}$ & $\begin{array}{c}\text { Sm } \\
\text { in } \mu g / L\end{array}$ & $\begin{array}{c}\mathrm{SO4} \\
\text { in } \mathrm{mg} / \mathrm{L}\end{array}$ & $\begin{array}{c}\text { Sr } \\
\text { in } \mu g / L\end{array}$ & $\begin{array}{c}\mathrm{Ta} \\
\text { in } \mu \mathrm{g} / \mathrm{L}\end{array}$ & $\begin{array}{c}\text { Tb } \\
\text { in } \mu \mathrm{g} / \mathrm{L}\end{array}$ & $\begin{array}{c}\text { Th } \\
\text { in } \mu \mathrm{g} / \mathrm{L}\end{array}$ & $\begin{array}{c}\mathrm{Ti} \\
\text { in } \mu \mathrm{g} / \mathrm{L}\end{array}$ & $\begin{array}{c}\text { TI } \\
\text { in } \mu \mathrm{g} / \mathrm{L}\end{array}$ & $\begin{array}{c}\text { Tm } \\
\text { in } \mu \mathrm{g} / \mathrm{L}\end{array}$ & $\begin{array}{c}U \\
\text { in } \mu g / L\end{array}$ & $\begin{array}{c}V \\
\text { in } \mu \mathrm{g} / \mathrm{L}\end{array}$ \\
\hline 10HG1 & 22.2 & 59.9 & 0.01 & 1,290 & 2,220 & 0.03 & $<0.005$ & $<0.2$ & 18.8 & 0.1 & $<0.005$ & 0.96 & 10.6 \\
\hline 10HG2 & 17.5 & 31.3 & $<0.01$ & 1,370 & 1,870 & 0.03 & $<0.005$ & $<0.2$ & 20.4 & $<0.1$ & $<0.005$ & 2.64 & 7 \\
\hline 10HG3 & 2.1 & 18 & 0.01 & 340 & 896 & $<0.02$ & $<0.005$ & $<0.2$ & 5.4 & $<0.1$ & $<0.005$ & 0.68 & 4.1 \\
\hline 10HG4 & 8.3 & 20.1 & $<0.01$ & 829 & 1,180 & $<0.02$ & $<0.005$ & $<0.2$ & 12.8 & $<0.1$ & $<0.005$ & 1.76 & 5.3 \\
\hline 10HG5 & 11.1 & 19.6 & $<0.01$ & 1,020 & 1,220 & $<0.02$ & $<0.005$ & $<0.2$ & 15.8 & $<0.1$ & $<0.005$ & 2.1 & 6 \\
\hline 10HG6 & $<10$ & 13.8 & $<0.1$ & 892 & 1,060 & $<0.2$ & $<0.05$ & $<2$ & 10 & $<1$ & $<0.05$ & $<1$ & $<5$ \\
\hline 10HG7 & $<10$ & 12.6 & $<0.1$ & 932 & 492 & $<0.2$ & $<0.05$ & $<2$ & 10.2 & $<1$ & $<0.05$ & $<1$ & $<5$ \\
\hline 10HG8 & $<10$ & 13.8 & $<0.1$ & 880 & 1,150 & $<0.2$ & $<0.05$ & $<2$ & 10.5 & $<1$ & $<0.05$ & $<1$ & $<5$ \\
\hline 10HG9 & $<10$ & 11.8 & $<0.1$ & 770 & 1,280 & $<0.2$ & $<0.05$ & $<2$ & 9.4 & $<1$ & $<0.05$ & $<1$ & $<5$ \\
\hline $10 \mathrm{HG} 10$ & $<10$ & 9.5 & $<0.1$ & 777 & 1,350 & $<0.2$ & $<0.05$ & $<2$ & 8.3 & $<1$ & $<0.05$ & $<1$ & $<5$ \\
\hline 10HG4-2 & $\begin{array}{l}\text { Low-flov } \\
68.2 \\
\text { Low-flov }\end{array}$ & $\begin{array}{l}\text { Sept. } 2010 \\
10 \\
\text { May } 2011\end{array}$ & $<0.01$ & 450 & 1,190 & 0.03 & $<0.005$ & $<0.2$ & 20.3 & $<0.1$ & 0.006 & 3.08 & 4.2 \\
\hline 11HG1-2 & 2 & 19 & $<0.01$ & 870 & 876 & 0.28 & $<0.005$ & 0.37 & 14.2 & $<0.1$ & $<0.005$ & 1.37 & 3.5 \\
\hline 11HG2-2 & 14.7 & 25 & $<0.01$ & 1,000 & 1,640 & 0.28 & $<0.005$ & 0.37 & 17 & $<0.1$ & $<0.005$ & 2.55 & 8.8 \\
\hline 11HG3-2 & 1.1 & 20 & $<0.01$ & 190 & 874 & 0.27 & $<0.005$ & 0.36 & 3.4 & $<0.1$ & $<0.005$ & 1.08 & 3.8 \\
\hline 11HG4-2 & 7.9 & 21 & $<0.01$ & 600 & 1,180 & 0.28 & $<0.005$ & 0.37 & 9.8 & $<0.1$ & $<0.005$ & 1.69 & 5.8 \\
\hline 11HG5-2 & 6.4 & 21 & $<0.01$ & 570 & 1,150 & 0.27 & $<0.005$ & 0.36 & 9.9 & $<0.1$ & $<0.005$ & 1.73 & 5.5 \\
\hline 11HG6-2 & $\begin{array}{l}8 \\
\text { High-flov }\end{array}$ & $\begin{array}{l}20 \\
N \text { March } 20\end{array}$ & $\begin{array}{l}<0.01 \\
11\end{array}$ & 600 & 1,050 & 0.28 & $<0.005$ & 0.36 & 10.4 & $<0.1$ & $<0.005$ & 1.68 & 5 \\
\hline 11HG1 & 1.3 & 17 & $<0.01$ & 210 & 320 & $<0.02$ & 0.03 & 0.21 & 6.3 & $<0.1$ & 0.04 & 0.38 & 3.6 \\
\hline $11 \mathrm{HG} 2$ & 3.3 & 18 & $<0.01$ & 270 & 410 & $<0.02$ & 0.02 & $<0.2$ & 5.8 & $<0.1$ & 0.04 & 0.39 & 3.5 \\
\hline $11 \mathrm{HG} 3$ & $<1$ & 16 & $<0.01$ & 30 & 171 & $<0.02$ & 0.03 & $<0.2$ & 1.8 & $<0.1$ & 0.03 & 0.12 & 2.6 \\
\hline $11 \mathrm{HG} 4$ & 1.6 & 19 & 0.04 & 100 & 249 & $<0.02$ & 0.03 & 0.21 & 6.9 & $<0.1$ & 0.04 & 0.21 & 4.3 \\
\hline
\end{tabular}


Table 7 (cont'd)

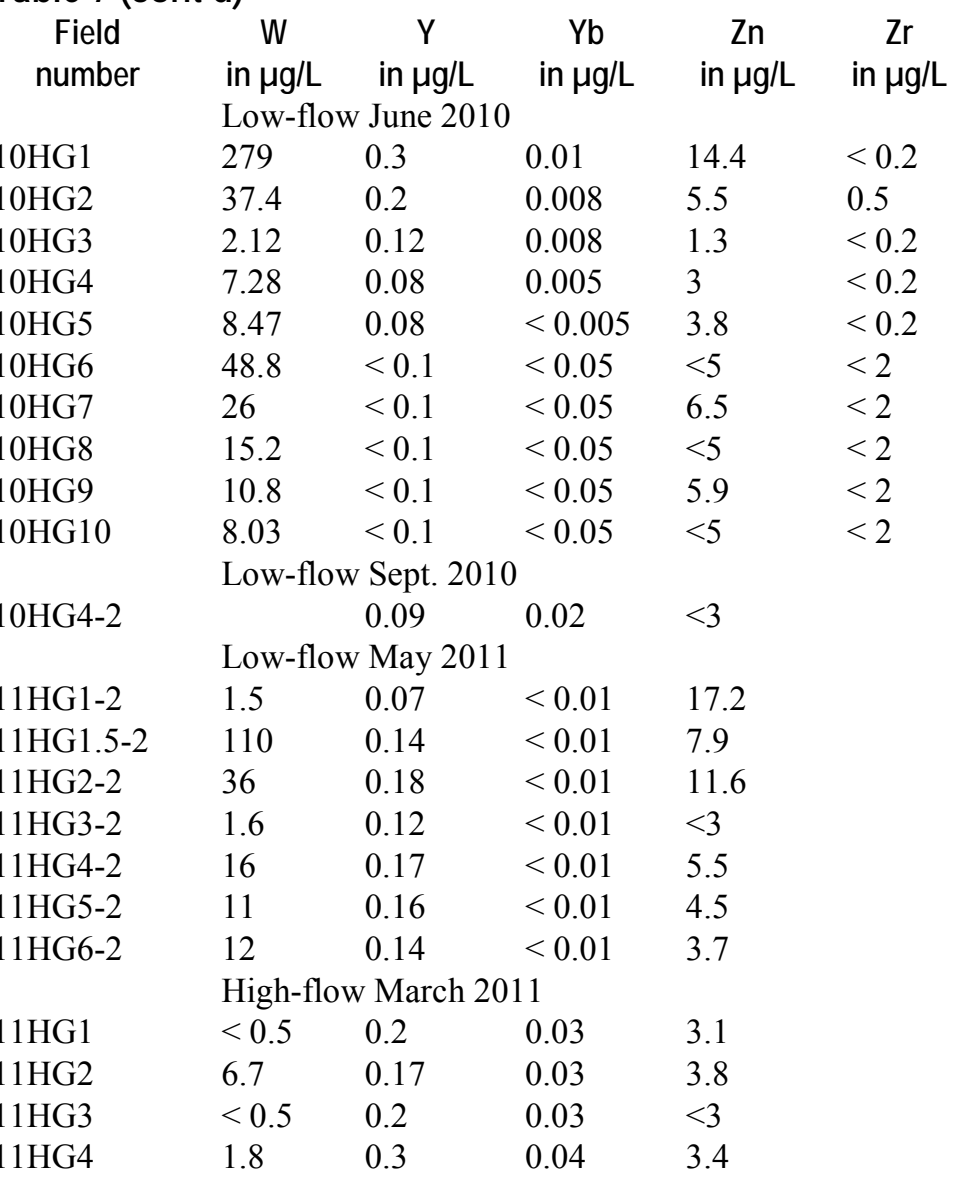


Table 8. Stable-isotope levels and calculated percent effluent in stream waters collected from Harley Gulch, Lake County, California.

\begin{tabular}{|c|c|c|c|c|c|c|c|c|}
\hline Sample & $\begin{array}{c}\delta^{18} 0( \\
\text { percentD) } \\
x 1000\end{array}$ & $\begin{array}{c}\delta D( \\
\text { percentD) } \\
x 1000\end{array}$ & $\begin{array}{c}\mathrm{Cl} \\
\text { in } \mu \mathrm{g} / \mathrm{g}\end{array}$ & $\begin{array}{c}\mathrm{SO}_{4} \\
\text { in } \mu \mathrm{g} / \mathrm{g}\end{array}$ & $\begin{array}{c}\text { percent } \\
\text { Effluent } \\
\delta 180\end{array}$ & $\begin{array}{c}\text { percent } \\
\text { Effluent } \\
\text { סD }\end{array}$ & $\begin{array}{l}\text { percent } \\
\text { Effluent } \\
\text { Cl }\end{array}$ & $\begin{array}{r}\text { percent Effl } \\
\mathrm{SO}_{4}\end{array}$ \\
\hline & \multicolumn{8}{|c|}{ Low-flow Jun. 2010} \\
\hline 10HG1 & -5.77 & -49.66 & $1,131.8$ & 1,068 & 101.03 & 127.34 & 98.40 & 52.61 \\
\hline $10 \mathrm{HG} 2$ & -6.47 & -51.51 & 1,021 & 1,409 & 68.20 & 76.89 & 88.68 & 69.59 \\
\hline $10 \mathrm{HG} 3$ & -6.82 & -52.17 & 43.6 & 321 & 57.49 & 71.80 & 2.93 & 15.43 \\
\hline 10HG4 & -7.05 & -54.08 & 403.4 & 751.4 & 50.46 & 57.09 & 34.50 & 36.85 \\
\hline 10HG5 & -6.84 & -53.76 & 572.6 & 959.3 & 56.88 & 59.55 & 49.34 & 47.20 \\
\hline 10HG6 & -6.54 & -52.1 & 748.5 & 1,196 & 66.06 & 72.34 & 64.77 & 58.98 \\
\hline 10HG7 & -5.43 & -48.51 & 874.5 & 1,424 & 100.00 & 100.00 & 75.83 & 70.33 \\
\hline 10HG8 & -5.75 & -49.13 & 511 & 942 & 90.21 & 95.22 & 43.94 & 46.34 \\
\hline 10HG9 & -5.97 & -50.65 & 484.1 & 1,015 & 83.49 & 83.51 & 41.58 & 49.98 \\
\hline \multirow[t]{2}{*}{ 10HG10 } & -6.56 & -51.46 & 431.9 & $1,034.4$ & 65.44 & 77.27 & 37.00 & 50.94 \\
\hline & \multicolumn{8}{|c|}{ Low-flow Sept. 2010} \\
\hline \multirow[t]{2}{*}{ 10HG4-2 } & -7.01 & -53.23 & 862 & 813.5 & 51.68 & 63.64 & 74.73 & 39.95 \\
\hline & \multicolumn{8}{|c|}{ Low-flow May 2011} \\
\hline 11HG1 & -7.49 & -53.56 & 60.4 & 964.56 & 55.76 & 85.36 & 4.40 & 47.46 \\
\hline $11 \mathrm{HG} 1.5$ & -6.53 & -52.38 & 762.6 & $1,275.5$ & 100.00 & 70.18 & 66.01 & 62.94 \\
\hline 11HG2 & -6.82 & -52.88 & 752.6 & $1,260.3$ & 86.64 & 66.33 & 65.13 & 62.19 \\
\hline $11 \mathrm{HG} 3$ & -7.69 & -53.93 & 29.6 & 201.6 & 46.54 & 58.24 & 1.70 & 9.49 \\
\hline $11 \mathrm{HG} 4$ & -7.23 & -53.34 & 354.2 & 684.6 & 67.74 & 62.79 & 30.18 & 33.53 \\
\hline 11HG5 & -7.24 & -53.66 & 320.5 & 660 & 67.28 & 60.32 & 27.22 & 32.30 \\
\hline \multirow[t]{2}{*}{ 11HG7 } & -7.13 & -52.94 & 391.9 & 759 & 72.35 & 65.87 & 33.49 & 37.23 \\
\hline & \multicolumn{8}{|c|}{ High-flow Mar. 2011} \\
\hline 11HG1-2 & -9.7 & -65.58 & 10.9 & 228.1 & 0.63 & 0.00 & 0.06 & 10.81 \\
\hline $11 \mathrm{HG} 2-2$ & -9.35 & -63.75 & 67.5 & 285 & 11.60 & 10.72 & 5.03 & 13.64 \\
\hline 11HG3-2 & -9.72 & -65.29 & 4.8 & 30.2 & 0.00 & 1.70 & -0.47 & 0.96 \\
\hline \multirow[t]{2}{*}{$11 \mathrm{HG} 4-2$} & -9.54 & -64.45 & 25.8 & 111 & 5.64 & 6.62 & 1.37 & 4.98 \\
\hline & \multicolumn{8}{|c|}{ High-flow Jun. 2011} \\
\hline 11HG1-3 & -8.1 & -57.85 & 101.6 & 1,379 & 20.69 & 39.18 & 8.02 & 68.09 \\
\hline $11 \mathrm{HG} 2-3$ & -7.06 & -55.81 & 758.6 & $1,251.3$ & 50.15 & 43.76 & 65.66 & 61.74 \\
\hline $11 \mathrm{HG} 3-3$ & -8.04 & -58.51 & 73.3 & 11 & 20.18 & 22.96 & 5.54 & 0.00 \\
\hline
\end{tabular}

*Percentages of effluent fluid are calculated using a two-end member system in which meteoric water from the nearby Clyde mine is treated as the background, meteoric end-member 1, and either effluent collected from the adit in 1997 or water sampled from sample sites HG1.5 or HG7 are used as end-member 2. Which sample is used as the second end member depends on the conditions during the specific sampling event. 
Table 9. Total mercury $\left(\mathrm{Hg}_{\mathrm{T}}\right)$ and monomethyl mercury $(\mathrm{MMeHg})(\mu \mathrm{g} / \mathrm{g}$, wet wt) in individual composites of invertebrates collected at Harley Gulch in 2002, 2007, 2008, and 2010, and at a reference site, Bear River at Highway 20 (BR 20), during 1999-2002, Lake County, California.

\begin{tabular}{|c|c|c|c|c|c|c|c|c|c|c|c|c|}
\hline Site-Year & $\begin{array}{c}\text { Date } \\
\text { collected } \\
\end{array}$ & Sample number & Order & Family & Age & $\mathrm{N}$ & Mass $(\mathrm{g})$ & $\begin{array}{c}\text { Ave. Mass } \\
(\mathrm{g})\end{array}$ & $\begin{array}{c}\text { Moisture } \\
( \\
\text { percent }) \\
\end{array}$ & $\begin{array}{c}\mathrm{Hg}_{\mathrm{T}} \\
(\mu \mathrm{g} / \mathrm{g}, \text { wet wt })\end{array}$ & $\begin{array}{c}\mathrm{MMeHg} \\
(\mu \mathrm{g} / \mathrm{g}, \text { wet } w \mathrm{t})\end{array}$ & $\begin{array}{r}\text { percent } \\
\mathrm{MMeHg}\end{array}$ \\
\hline BR20-99 & $10 / 1 / 1999$ & BY-BH20-100199-001 & Hemiptera & Gerridae & adult & 21 & 1.07 & 0.051 & 57.20 & NA1 & 0.027 & NA \\
\hline BR20-00 & $9 / 12 / 2000$ & BY-BH20-091200-001 & Hemiptera & Gerridae & adult & 26 & 1.3 & 0.050 & 76.10 & 0.028 & 0.027 & 95.00 \\
\hline BR20-01 & $9 / 15 / 2001$ & BY-BH20-091501-009 & Odonata & Aeshnidae & larvae & 7 & 3.89 & 0.556 & 81.90 & 0.022 & 0.014 & 64.20 \\
\hline BR20-01 & $9 / 15 / 2001$ & BY-BH20-091501-003 & Hemiptera & Gerridae & adult & 25 & 1.25 & 0.050 & 64.70 & 0.070 & 0.050 & 71.60 \\
\hline BR20-02 & $8 / 23 / 2002$ & BY-BR20-082302-005 & Odonata & Aeshnidae & larvae & 8 & 3.63 & 0.454 & 79.90 & 0.024 & 0.026 & 107.60 \\
\hline BR20-02 & $8 / 23 / 2002$ & BY-BR20-082302-001 & Hemiptera & Gerridae & adult & 25 & 1.37 & 0.055 & 63.00 & 0.045 & 0.041 & 91.80 \\
\hline HGDS-02 & $10 / 16 / 2002$ & CA02A001 & Odonata & Aeshnidae & larvae & 9 & 2.3 & 0.256 & 80.60 & 3.996 & 3.162 & 79.10 \\
\hline HGDS-02 & $10 / 16 / 2002$ & CA02A002 & Odonata & Libellulidae & larvae & 9 & 4.56 & 0.507 & 80.70 & 3.783 & 2.548 & 67.30 \\
\hline HG3 & $5 / 16 / 2007$ & HAR-SITE3-51607-001 & Hemiptera & Gerridae & adult & 25 & 1.56 & 0.062 & 75.30 & 0.159 & 0.146 & 91.80 \\
\hline HG3 & $5 / 16 / 2007$ & HAR-SITE3-51607-002 & Odonata & Libellulidae & larvae & 5 & 2.29 & 0.458 & 82.90 & 0.191 & 0.218 & 114.10 \\
\hline HG4 & $5 / 16 / 2007$ & HAR-SITE4-51607-001 & Hemiptera & Gerridae & adult & 17 & 1.13 & 0.066 & 65.20 & 0.302 & 0.241 & 79.80 \\
\hline HG4 & $5 / 16 / 2007$ & HAR-SITE4-51607-002 & Odonata & Aeshnidae & larvae & 3 & 4.1 & 1.367 & 79.30 & 1.180 & 0.855 & 72.50 \\
\hline HG4 & $5 / 16 / 2007$ & HAR-SITE4-51607-003 & Odonata & Libellulidae & larvae & 9 & 2.41 & 0.268 & 82.20 & 0.961 & 0.357 & 37.10 \\
\hline HG5 & $5 / 16 / 2007$ & HAR-SITE5-51607-001 & Odonata & Libellulidae & larvae & 4 & 1.69 & 0.423 & 83.90 & 0.581 & 0.540 & 92.90 \\
\hline HG6 & $5 / 16 / 2007$ & HAR-SITE6-51607-002 & Odonata & Libellulidae & larvae & 5 & 3.03 & 0.606 & 79.70 & 1.920 & 1.570 & 81.80 \\
\hline HG6 & $5 / 16 / 2007$ & HAR-SITE6-51607-004 & Odonata & Aeshnidae & larvae & 4 & 2.83 & 0.708 & 83.40 & 0.492 & 0.445 & 90.40 \\
\hline HG7 & $5 / 16 / 2007$ & HAR-SITE7-51607-001 & Hemiptera & Gerridae & adult & 25 & 1.46 & 0.058 & 73.70 & 0.546 & 0.547 & 100.20 \\
\hline HG7 & $5 / 16 / 2007$ & HAR-SITE7-51607-002 & Odonata & Libellulidae & larvae & 5 & 1.8 & 0.360 & 87.70 & 0.961 & 0.915 & 95.20 \\
\hline HG8-07 & $5 / 16 / 2007$ & HAR-SITE8-51607-001 & Odonata & Aeshnidae & larvae & 5 & 3.61 & 0.722 & 81.90 & 0.863 & 0.498 & 57.70 \\
\hline HG8-07 & $5 / 16 / 2007$ & HAR-SITE8-51607-002 & Odonata & Libellulidae & larvae & 2 & 0.82 & 0.410 & 89.80 & 0.640 & 0.443 & 69.20 \\
\hline HG1 & $5 / 21 / 2008$ & CR-HG1-052108-001 & Coleoptera & Hydrophilidae & larvae & 6 & 1.86 & 0.310 & 86.50 & NA & 0.036 & NA \\
\hline HG1 & $5 / 21 / 2008$ & CR-HG1-052108-002 & Coleoptera & Hydrophilidae & larvae & 6 & 1.45 & 0.242 & 79.43 & NA & 0.029 & NA \\
\hline HG1 & $5 / 21 / 2008$ & CR-HG1-052108-003 & Odonata & Libellulidae & larvae & 2 & 0.66 & 0.330 & 83.83 & NA & 0.186 & NA \\
\hline HG1 & $5 / 21 / 2008$ & CR-HG1-052108-006 & Odonata & Coenagrionidae & larvae & 8 & 0.39 & 0.049 & 83.46 & NA & 0.204 & NA \\
\hline HG1 & $5 / 21 / 2008$ & CR-HG1-052180-004 & Coleoptera & Hydrophilidae & adult & 4 & 1.08 & 0.270 & 70.25 & NA & 0.097 & NA \\
\hline HG1 & $5 / 21 / 2008$ & CR-HG1-052180-005 & Coleoptera & Dytiscidae & adult & 16 & 0.75 & 0.047 & 71.63 & NA & 0.195 & NA \\
\hline HG2 & $5 / 21 / 2008$ & CR-HG2-052108-001 & Coleoptera & Dytiscidae & adult & 15 & 0.81 & 0.054 & 83.67 & NA & 0.069 & NA \\
\hline HG2 & $5 / 21 / 2008$ & CR-HG2-052108-002 & Odonata & Coenagrionidae & larvae & 16 & 1.03 & 0.064 & 84.78 & NA & 0.059 & NA \\
\hline HG2 & $5 / 21 / 2008$ & CR-HG2-052108-003 & Odonata & Coenagrionidae & larvae & 23 & 1.11 & 0.048 & 83.88 & NA & 0.114 & NA \\
\hline HG2a & $5 / 21 / 2008$ & CR-HG2A-052108-001 & Hemiptera & Gerridae & adult & 27 & 1.81 & 0.067 & 74.34 & NA & 0.056 & NA \\
\hline HG2a & $5 / 21 / 2008$ & CR-HG2A-052108-002 & Odonata & Libellulidae & larvae & 2 & 0.84 & 0.420 & 86.41 & NA & 0.087 & NA \\
\hline
\end{tabular}


Table 9 (continued). Total mercury $\left(\mathrm{Hg}_{\mathrm{T}}\right)$ and monomethyl mercury $(\mathrm{MMeHg})(\mu \mathrm{g} / \mathrm{g}$, wet wt) in individual composites of invertebrates collected at Harley Gulch in 2002, 2007, 2008, 2010 and 2011, and at a reference site, Bear River at Highway 20 (BR 20), during 1999-2002.

\begin{tabular}{|c|c|c|c|c|c|c|c|c|c|c|c|c|}
\hline Site-Year & $\begin{array}{c}\text { Date } \\
\text { collected }\end{array}$ & Sample number & Order & Family & Age & $\mathrm{N}$ & Mass $(\mathrm{g})$ & Ave. Mass (g) & $\begin{array}{c}\text { Moisture ( } \\
\text { percent) }\end{array}$ & $\begin{array}{c}\mathrm{Hg}_{\mathrm{T}} \\
(\mu \mathrm{g} / \mathrm{g}, \text { wet wt }) \\
\end{array}$ & $\begin{array}{c}\mathrm{MMeHg} \\
(\mu \mathrm{g} / \mathrm{g}, \text { wet wt) }\end{array}$ & percent $\mathrm{MMeHg}$ \\
\hline HG2a & $5 / 21 / 2008$ & CR-HG2A-052108-003 & Coleoptera & Hydrophilidae & larvae & 5 & 1.12 & 0.224 & 90.36 & NA & 0.054 & NA \\
\hline $\mathrm{HG} 2 \mathrm{a}$ & $5 / 21 / 2008$ & CR-HG2A-052108-004 & Odonata & Coenagrionidae & larvae & 19 & 1.06 & 0.056 & 80.75 & NA & 0.131 & NA \\
\hline $\mathrm{HG} 2 \mathrm{a}$ & $5 / 21 / 2008$ & CR-HG2A-052108-005 & Odonata & Coenagrionidae & larvae & 24 & 1.11 & 0.046 & 84.43 & NA & 0.110 & NA \\
\hline HG3 & $5 / 21 / 2008$ & CR-HG3-052108-001 & Odonata & Coenagrionidae & larvae & 21 & 0.82 & 0.039 & 87.98 & NA & 0.101 & NA \\
\hline HG3 & $5 / 21 / 2008$ & CR-HG3-052108-002 & Odonata & Libellulidae & larvae & 5 & 0.99 & 0.198 & 94.23 & NA & 0.057 & NA \\
\hline HG3 & $5 / 21 / 2008$ & CR-HG3-052108-003 & Hemiptera & Gerridae & adult & 20 & 1.11 & 0.056 & 82.29 & NA & 0.035 & NA \\
\hline HG3 & $5 / 21 / 2008$ & CR-HG3-052108-004 & Hemiptera & Gerridae & adult & 18 & 0.99 & 0.055 & 85.41 & NA & 0.031 & NA \\
\hline HG3 & $5 / 21 / 2008$ & CR-HG3-052108-005 & Coleoptera & Dytiscidae & adult & 20 & 1.18 & 0.059 & 80.04 & NA & 0.123 & NA \\
\hline HG3 & $5 / 21 / 2008$ & CR-HG3-052108-006 & Hemiptera & Belostomatidae & adult & 5 & 1.56 & 0.312 & 73.48 & NA & 1.710 & NA \\
\hline HG3 & $5 / 21 / 2008$ & CR-HG3-052108-007 & Megaloptera & Corydalidae & larvae & 1 & 0.65 & 0.650 & 80.00 & NA & 0.023 & NA \\
\hline HG5 & $5 / 21 / 2008$ & CR-HG5-052108-001 & Hemiptera & Gerridae & adult & 25 & 1.87 & 0.075 & 79.22 & NA & 0.063 & NA \\
\hline HG5 & $5 / 21 / 2008$ & CR-HG5-052108-002 & Odonata & Coenagrionidae & larvae & 35 & 1.27 & 0.036 & 84.60 & NA & 0.154 & NA \\
\hline HG5 & $5 / 21 / 2008$ & CR-HG5-052108-003 & Hemiptera & Belostomatidae & adult & 3 & 1.18 & 0.393 & 73.76 & NA & 1.450 & NA \\
\hline HG5 & $5 / 21 / 2008$ & CR-HG5-052108-004 & Odonata & Aeshnidae & larvae & 3 & 1.41 & 0.470 & 84.57 & NA & 0.169 & NA \\
\hline HG5 & $5 / 21 / 2008$ & CR-HG5-052108-005 & Odonata & Libellulidae & larvae & 6 & 2.60 & 0.433 & 84.59 & NA & 0.254 & NA \\
\hline HG5 & $5 / 21 / 2008$ & CR-HG5-052108-006 & Odonata & Libellulidae & larvae & 7 & 1.12 & 0.160 & 85.17 & NA & 0.357 & NA \\
\hline HG7 & $6 / 4 / 2008$ & CR-HG7-060408-001 & Odonata & Libellulidae & larvae & 3 & 1.32 & 0.440 & 90.02 & NA & 0.103 & NA \\
\hline HG7 & $6 / 4 / 2008$ & CR-HG7-060408-002 & Odonata & Libellulidae & larvae & 13 & 1.58 & 0.122 & 89.35 & NA & 0.109 & NA \\
\hline HG7 & $6 / 4 / 2008$ & CR-HG7-060408-003 & Odonata & Coenagrionidae & larvae & 40 & 1.33 & 0.033 & 85.22 & NA & 0.125 & NA \\
\hline HG7 & $6 / 4 / 2008$ & CR-HG7-060408-004 & Hemiptera & Gerridae & adult & 30 & 1.77 & 0.059 & 78.67 & NA & 0.130 & NA \\
\hline HG8-08 & $6 / 4 / 2008$ & CR-HG8-060408-001 & Hemiptera & Gerridae & adult & 30 & 1.78 & 0.059 & 75.18 & NA & 0.091 & NA \\
\hline HG8-08 & $6 / 4 / 2008$ & CR-HG8-060408-002 & Coleoptera & Hydrophilidae & adult & 1 & 1.45 & 1.450 & 62.43 & NA & 0.059 & NA \\
\hline HG8-08 & $6 / 4 / 2008$ & CR-HG8-060408-003 & Odonata & Libellulidae & larvae & 10 & 2.49 & 0.249 & 84.25 & NA & 0.144 & NA \\
\hline HG8-08 & $6 / 4 / 2008$ & CR-HG8-060408-004 & Odonata & Lestidae & larvae & 25 & 1.51 & 0.060 & 91.38 & NA & 0.066 & NA \\
\hline HG8-08 & $6 / 4 / 2008$ & CR-HG8-060408-005 & Odonata & Coenagrionidae & larvae & 22 & 0.84 & 0.038 & 85.69 & NA & 0.126 & NA \\
\hline HG9 & $6 / 4 / 2008$ & CR-HG9-060408-001 & Hemiptera & Gerridae & adult & 25 & 1.35 & 0.054 & 77.37 & NA & 0.046 & NA \\
\hline HG9 & $6 / 4 / 2008$ & CR-HG9-060408-002 & Odonata & Libellulidae & larvae & 4 & 1.17 & 0.293 & 87.32 & NA & 0.055 & NA \\
\hline HG9 & $6 / 4 / 2008$ & CR-HG9-060408-003 & Odonata & Lestidae & larvae & 7 & 0.67 & 0.096 & 91.06 & NA & 0.016 & NA \\
\hline HG9 & $6 / 4 / 2008$ & CR-HG9-060408-004 & Odonata & Coenagrionidae & larvae & 21 & 0.77 & 0.037 & 88.34 & NA & 0.034 & NA \\
\hline HG10 & $6 / 4 / 2008$ & CR-HG10-060408-001 & Hemiptera & Gerridae & adult & 30 & 1.86 & 0.062 & 80.89 & NA & 0.039 & NA \\
\hline HG10 & $6 / 4 / 2008$ & CR-HG10-060408-002 & Odonata & Libellulidae & larvae & 5 & 1.09 & 0.218 & 86.71 & NA & 0.072 & NA \\
\hline HG10 & $6 / 4 / 2008$ & CR-HG10-060408-003 & Odonata & Coenagrionidae & larvae & 30 & 0.93 & 0.031 & 87.44 & NA & 0.046 & NA \\
\hline HG11 & $6 / 4 / 2008$ & CR-HG11-060408-001 & Hemiptera & Gerridae & adult & 30 & 2.31 & 0.077 & 74.01 & NA & 0.034 & NA \\
\hline HG11 & $6 / 4 / 2008$ & CR-HG11-060408-002 & Odonata & Coenagrionidae & larvae & 30 & 0.93 & 0.031 & 91.34 & NA & 0.025 & NA \\
\hline
\end{tabular}


Table 9 (continued). Total mercury $\left(\mathrm{Hg}_{\mathrm{T}}\right)$ and monomethyl mercury ( $\left.\mathrm{MMeHg}\right)(\mu \mathrm{g} / \mathrm{g}$, wet wt) in individual composites of invertebrates collected at Harley Gulch in 2002, 2007, 2008, 2010 and 2011, and at a reference site, Bear River at Highway 20 (BR 20), during 1999-2002.

\begin{tabular}{|c|c|c|c|c|c|c|c|c|c|c|c|c|}
\hline Site-Year & $\begin{array}{c}\text { Date } \\
\text { collected }\end{array}$ & Sample number & Order & Family & Age & $\mathrm{N}$ & Mass (g) & Ave. Mass (g) & $\begin{array}{c}\text { Moisture ( } \\
\text { percent) }\end{array}$ & $\begin{array}{c}\mathrm{Hg}_{\mathrm{T}} \\
(\mu \mathrm{g} / \mathrm{g}, \text { wet wt) }\end{array}$ & $\begin{array}{c}\mathrm{MMeHg} \\
(\mu \mathrm{g} / \mathrm{g}, \text { wet } \mathrm{wt})\end{array}$ & percent $\mathrm{MMeHg}$ \\
\hline HG11 & $6 / 4 / 2008$ & CR-HG11-060408-003 & Megaloptera & Corydalidae & larvae & 2 & 1.03 & 0.515 & 84.94 & NA & 0.081 & NA \\
\hline HG11 & $6 / 4 / 2008$ & CR-HG11-060408-004 & Odonata & Aeshnidae & larvae & 3 & 2.53 & 0.843 & 83.93 & NA & 0.093 & NA \\
\hline HG11 & $6 / 4 / 2008$ & CR-HG11-060408-005 & Odonata & Libellulidae & larvae & 6 & 2.19 & 0.365 & 82.96 & NA & 0.106 & NA \\
\hline HG11 & $6 / 4 / 2008$ & CR-HG11-060408-006 & Coleoptera & Dytiscidae & adult & 9 & 0.62 & 0.069 & 72.49 & NA & 0.087 & NA \\
\hline HG12 & $6 / 4 / 2008$ & CR-HG12-060408-001 & Hemiptera & Gerridae & adult & 20 & 1.33 & 0.067 & 77.09 & NA & 0.037 & NA \\
\hline HG12 & $6 / 4 / 2008$ & CR-HG12-060408-002 & Hemiptera & Gerridae & adult & 20 & 1.42 & 0.071 & 78.64 & NA & 0.037 & NA \\
\hline HG12 & $6 / 4 / 2008$ & CR-HG12-060408-003 & Odonata & Lestidae & larvae & 10 & 0.6 & 0.060 & 92.81 & NA & 0.009 & NA \\
\hline HG12 & $6 / 4 / 2008$ & CR-HG12-060408-004 & Megaloptera & Corydalidae & larvae & 2 & 1.03 & 0.515 & 80.58 & NA & 0.056 & NA \\
\hline HG13 & $6 / 4 / 2008$ & CR-HG13-060408-001 & Hemiptera & Gerridae & adult & 25 & 1.92 & 0.077 & 76.89 & NA & 0.025 & NA \\
\hline HG13 & $6 / 4 / 2008$ & CR-HG13-060408-002 & Odonata & Lestidae & larvae & 10 & 1.05 & 0.105 & 87.44 & NA & 0.004 & NA \\
\hline HG14 & $6 / 4 / 2008$ & CR-HG!4-060408-001 & Odonata & Lestidae & larvae & 7 & 0.82 & 0.117 & 85.56 & NA & 0.004 & NA \\
\hline HG14 & $6 / 4 / 2008$ & CR-HG!4-060408-002 & Hemiptera & Gerridae & adult & 30 & 1.96 & 0.065 & 78.93 & NA & 0.023 & NA \\
\hline UDLW & $6 / 8 / 2010$ & CR-UDLW-060810-001 & Odonata & Coenagrionidae & larvae & 25 & 1.33 & 0.053 & 86.18 & 0.461 & 0.021 & 4.56 \\
\hline UDLW & $6 / 8 / 2010$ & CR-UDLW-060810-002 & Coleoptera & Dytiscidae & adult & 21 & 0.8 & 0.038 & 85.62 & 0.232 & 0.063 & 26.94 \\
\hline UDLW & $6 / 8 / 2010$ & CR-UDLW-060810-003 & Hemiptera & Gerridae & adult & 30 & 1.83 & 0.061 & 75.44 & 0.163 & 0.062 & 38.28 \\
\hline UDUP & $6 / 8 / 2010$ & CR-UDUP-060810-001 & Coleoptera & Hydrophilidae & larvae & 7 & 1.9 & 0.271 & 85.72 & 1.570 & 0.049 & 3.13 \\
\hline UDUP & $6 / 8 / 2010$ & CR-UDUP-060810-002 & Odonata & Coenagrionidae & larvae & 38 & 2.18 & 0.057 & 83.01 & 1.990 & 0.048 & 2.43 \\
\hline UDUP & $6 / 8 / 2010$ & CR-UDUP-060810-003 & Coleoptera & Dytiscidae & adult & 24 & 1.22 & 0.051 & 78.51 & 0.828 & 0.070 & 8.48 \\
\hline UDUP & $6 / 8 / 2010$ & CR-UDUP-060810-004 & Hemiptera & Gerridae & adult & 10 & 0.62 & 0.062 & NA & 0.112 & 0.060 & 53.13 \\
\hline HG1 & $6 / 8 / 2010$ & CR-HG1-060810-001 & Coleoptera & Hydrophilidae & larvae & 3 & 0.68 & 0.227 & 87.82 & 0.503 & 0.021 & 4.08 \\
\hline HG1 & $6 / 8 / 2010$ & CR-HG1-060810-002 & Odonata & Coenagrionidae & larvae & 30 & 1.51 & 0.050 & 85.31 & 2.340 & 0.067 & 2.86 \\
\hline HG1 & $6 / 8 / 2010$ & CR-HG1-060810-003 & Odonata & Coenagrionidae & larvae & 30 & 1.45 & 0.048 & 86.03 & 2.050 & 0.062 & 3.00 \\
\hline HG1 & $6 / 8 / 2010$ & CR-HG1-060810-004 & Coleoptera & Dytiscidae & adult & 32 & 1.34 & 0.042 & 69.50 & 0.295 & 0.111 & 37.63 \\
\hline HG2 & $6 / 8 / 2010$ & CR-HG2-060810-001 & Coleoptera & Dytiscidae & adult & 25 & 1.02 & 0.041 & 84.32 & 0.406 & 0.188 & 46.31 \\
\hline HG2a & $6 / 8 / 2010$ & CR-HG2a-060810-001 & Coleoptera & Hydrophilidae & larvae & 4 & 1.21 & 0.303 & 88.06 & 0.171 & 0.020 & 11.64 \\
\hline $\mathrm{HG} 2 \mathrm{a}$ & $6 / 8 / 2010$ & CR-HG2a-060810-002 & Coleoptera & Hydrophilidae & larvae & 4 & 1.4 & 0.350 & 88.48 & 0.186 & 0.022 & 11.72 \\
\hline HG2a & $6 / 8 / 2010$ & CR-HG2a-060810-003 & Coleoptera & Dytiscidae & adult & 20 & 1.13 & 0.057 & 87.14 & 0.440 & 0.018 & 4.00 \\
\hline $\mathrm{HG} 2 \mathrm{a}$ & $6 / 8 / 2010$ & CR-HG2a-060810-004 & Hemiptera & Gerridae & adult & 22 & 1.54 & 0.070 & 75.72 & 0.139 & 0.074 & 52.88 \\
\hline HG3 & $6 / 8 / 2010$ & CR-HG3-060810-001 & Coleoptera & Hydrophilidae & larvae & 9 & 1.93 & 0.214 & 89.11 & 0.025 & 0.010 & 40.40 \\
\hline HG3 & $6 / 8 / 2010$ & CR-HG3-060810-002 & Odonata & Lestidae & larvae & 20 & 1.48 & 0.074 & 90.21 & 0.048 & 0.035 & 71.93 \\
\hline HG3 & $6 / 8 / 2010$ & CR-HG3-060810-003 & Odonata & Coenagrionidae & larvae & 11 & 0.45 & 0.041 & NA & 0.062 & 0.031 & 50.49 \\
\hline HG3 & $6 / 8 / 2010$ & CR-HG3-060810-005 & Coleoptera & Dytiscidae & adult & 16 & 1.08 & 0.068 & 77.85 & 0.129 & 0.040 & 30.70 \\
\hline HG3 & $6 / 8 / 2010$ & CR-HG3-060810-007 & Hemiptera & Gerridae & adult & 26 & 1.66 & 0.064 & 68.58 & 0.057 & 0.044 & 77.89 \\
\hline HG4 & $6 / 8 / 2010$ & CR-HG4-060810-001 & Coleoptera & Hydrophilidae & larvae & 4 & 0.64 & 0.160 & 95.55 & 0.217 & 0.021 & 9.63 \\
\hline
\end{tabular}


Table 9 (continued). Total mercury $\left(\mathrm{Hg}_{\mathrm{T}}\right)$ and monomethyl mercury $(\mathrm{MMeHg})(\mu \mathrm{g} / \mathrm{g}$, wet wt) in individual composites of invertebrates collected at Harley Gulch in 2002, 2007, 2008, 2010 and 2011, and at a reference site, Bear River at Highway 20 (BR 20), during 1999-2002.

\begin{tabular}{|c|c|c|c|c|c|c|c|c|c|c|c|c|}
\hline Site-Year & $\begin{array}{c}\text { Date } \\
\text { collected }\end{array}$ & Sample number & Order & Family & Age & $\mathrm{N}$ & $\operatorname{Mass}(\mathrm{g})$ & Ave. Mass (g) & $\begin{array}{c}\text { Moisture ( } \\
\text { percent) }\end{array}$ & $\begin{array}{c}\mathrm{Hg}_{\mathrm{T}} \\
(\mu \mathrm{g} / \mathrm{g}, \text { wet wt })\end{array}$ & $\begin{array}{c}\mathrm{MMeHg} \\
(\mu \mathrm{g} / \mathrm{g}, \text { wet } w \mathrm{t})\end{array}$ & percent $\mathrm{MMeHg}$ \\
\hline HG4 & $6 / 8 / 2010$ & CR-HG4-060810-002 & Odonata & Libellulidae & larvae & 3 & 0.65 & 0.217 & 94.76 & 0.094 & 0.041 & 43.74 \\
\hline HG4 & $6 / 8 / 2010$ & CR-HG4-060810-003 & Odonata & Coenagrionidae & larvae & 23 & 0.91 & 0.040 & 86.84 & 0.443 & 0.095 & 21.53 \\
\hline HG4 & $6 / 8 / 2010$ & CR-HG4-060810-004 & Odonata & Lestidae & larvae & 30 & 1.79 & 0.060 & 85.37 & 0.204 & 0.130 & 63.73 \\
\hline HG4 & $6 / 8 / 2010$ & CR-HG4-060810-005 & Hemiptera & Gerridae & adult & 25 & 1.91 & 0.076 & 75.85 & 0.116 & 0.078 & 66.90 \\
\hline HG5 & $6 / 10 / 2010$ & CR-HG5-061010-001 & Odonata & Libellulidae & larvae & 7 & 3.08 & 0.440 & 81.55 & 0.201 & 0.094 & 46.52 \\
\hline HG5 & $6 / 10 / 2010$ & CR-HG5-061010-002 & Odonata & Aeshnidae & larvae & 1 & 0.68 & 0.680 & 90.60 & 0.098 & 0.038 & 38.35 \\
\hline HG5 & $6 / 10 / 2010$ & CR-HG5-061010-003 & Hemiptera & Gerridae & adult & 21 & 1.5 & 0.071 & 70.48 & 0.106 & 0.065 & 61.70 \\
\hline HG5 & $6 / 10 / 2010$ & CR-HG5-061010-004 & Coleoptera & Dytiscidae & adult & 19 & 1.92 & 0.101 & 72.90 & 0.200 & 0.132 & 66.00 \\
\hline HG6 & $6 / 10 / 2010$ & CR-HG6-061010-002 & Odonata & Libellulidae & larvae & 5 & 2.63 & 0.526 & 86.46 & 0.253 & 0.127 & 50.20 \\
\hline HG6 & $6 / 10 / 2010$ & CR-HG6-061010-003 & Odonata & Coenagrionidae & larvae & 23 & 1.11 & 0.048 & 89.59 & 0.374 & 0.087 & 23.18 \\
\hline HG6 & $6 / 10 / 2010$ & CR-HG6-061010-004 & Hemiptera & Gerridae & adult & 19 & 1.3 & 0.068 & 82.19 & 0.066 & 0.040 & 60.61 \\
\hline HG6 & $6 / 10 / 2010$ & CR-HG6-061010-005 & Coleoptera & Dytiscidae & adult & 15 & 1.48 & 0.099 & 69.77 & 0.246 & 0.165 & 67.07 \\
\hline HG6 & $6 / 10 / 2010$ & CR-HG6-061010-006 & Coleoptera & Dytiscidae & adult & 14 & 1.6 & 0.114 & 69.45 & 0.236 & 0.235 & 99.58 \\
\hline HG7 & $6 / 10 / 2010$ & CR-HG7-061010-001 & Odonata & Libellulidae & larvae & 4 & 1.93 & 0.483 & 83.33 & 0.157 & 0.081 & 51.72 \\
\hline HG7 & $6 / 10 / 2010$ & CR-HG7-061010-002 & Odonata & Libellulidae & larvae & 3 & 1.37 & 0.457 & 90.02 & 0.118 & 0.082 & 69.66 \\
\hline HG7 & $6 / 10 / 2010$ & CR-HG7-061010-003 & Odonata & Coenagrionidae & larvae & 40 & 1.38 & 0.035 & 84.97 & 0.244 & 0.070 & 28.65 \\
\hline HG7 & $6 / 10 / 2010$ & CR-HG7-061010-004 & Hemiptera & Gerridae & adult & 25 & 1.6 & 0.064 & 73.18 & 0.151 & 0.105 & 69.54 \\
\hline HG8 & $6 / 10 / 2010$ & CR-HG8-061010-001 & Odonata & Libellulidae & larvae & 3 & 1.41 & 0.470 & 87.70 & 0.133 & 0.093 & 69.77 \\
\hline HG8 & $6 / 10 / 2010$ & CR-HG8-061010-002 & Odonata & Coenagrionidae & larvae & 35 & 1.13 & 0.032 & 85.81 & 0.283 & 0.074 & 26.11 \\
\hline HG8 & $6 / 10 / 2010$ & CR-HG8-061010-003 & Odonata & Lestidae & larvae & 25 & 1.62 & 0.065 & 89.29 & 0.113 & 0.054 & 47.70 \\
\hline HG8 & $6 / 10 / 2010$ & CR-HG8-061010-004 & Odonata & Lestidae & larvae & 25 & 1.17 & 0.047 & 86.87 & 0.136 & 0.075 & 54.85 \\
\hline HG8 & $6 / 10 / 2010$ & CR-HG8-061010-006 & Hemiptera & Gerridae & adult & 25 & 1.7 & 0.068 & 69.92 & 0.068 & 0.066 & 97.35 \\
\hline HG8a & $6 / 10 / 2010$ & CR-HG8a-061010-001 & Odonata & Aeshnidae & larvae & 3 & 2.61 & 0.870 & 67.17 & 0.081 & 0.041 & 50.25 \\
\hline HG8a & $6 / 10 / 2010$ & CR-HG8a-061010-002 & Odonata & Libellulidae & larvae & 2 & 1.19 & 0.595 & 86.00 & 0.159 & 0.140 & 88.05 \\
\hline HG8a & $6 / 10 / 2010$ & CR-HG8a-061010-003 & Odonata & Coenagrionidae & larvae & 30 & 1.85 & 0.062 & 82.46 & 0.203 & 0.066 & 32.41 \\
\hline HG8a & $6 / 10 / 2010$ & CR-HG8a-061010-004 & Odonata & Lestidae & larvae & 35 & 1.18 & 0.034 & 87.70 & 0.074 & 0.032 & 43.03 \\
\hline HG8a & $6 / 17 / 2010$ & CR-HG8a-061710-001 & Hemiptera & Gerridae & adult & 24 & 1.41 & 0.059 & 83.58 & 0.105 & 0.088 & 84.19 \\
\hline HG9 & $6 / 10 / 2010$ & CR-HG9-061010-001 & Coleoptera & Hydrophilidae & larvae & 5 & 1.02 & 0.204 & 89.93 & 0.048 & 0.005 & 9.87 \\
\hline HG9 & $6 / 10 / 2010$ & CR-HG9-061010-003 & Odonata & Lestidae & larvae & 17 & 1 & 0.059 & 90.49 & 0.031 & 0.006 & 17.57 \\
\hline HG9 & $6 / 10 / 2010$ & CR-HG9-061010-004 & Odonata & Coenagrionidae & larvae & 18 & 0.56 & 0.031 & 89.42 & 0.080 & 0.010 & 12.28 \\
\hline HG9 & $6 / 10 / 2010$ & CR-HG9-061010-005 & Hemiptera & Gerridae & adult & 25 & 1.41 & 0.056 & 77.88 & 0.052 & 0.026 & 49.23 \\
\hline HG10 & $6 / 10 / 2010$ & CR-HG10-061010-002 & Odonata & Libellulidae & larvae & 2 & 0.68 & 0.340 & 91.63 & 0.036 & 0.023 & 63.33 \\
\hline HG10 & $6 / 10 / 2010$ & CR-HG10-061010-003 & Coleoptera & Hydrophilidae & larvae & 8 & 0.39 & 0.049 & NA & 0.019 & 0.003 & 15.63 \\
\hline HG10 & $6 / 10 / 2010$ & CR-HG10-061010-005 & Coleoptera & Dytiscidae & adult & 16 & 0.84 & 0.053 & 80.43 & 0.069 & 0.028 & 40.55 \\
\hline
\end{tabular}


Table 9 (continued). Total mercury $\left(\mathrm{Hg}_{\mathrm{T}}\right)$ and monomethyl mercury $(\mathrm{MMeHg})(\mu \mathrm{g} / \mathrm{g}$, wet wt) in individual composites of invertebrates collected at Harley Gulch in 2002, 2007, 2008, 2010 and 2011, and at a reference site, Bear River at Highway 20 (BR 20), during 1999-2002.

\begin{tabular}{|c|c|c|c|c|c|c|c|c|c|c|c|c|}
\hline Site-Year & $\begin{array}{c}\text { Date } \\
\text { collected }\end{array}$ & Sample number & Order & Family & Age & $\mathrm{N}$ & Mass (g) & Ave. Mass (g) & $\begin{array}{c}\text { Moisture ( } \\
\text { percent) }\end{array}$ & $\begin{array}{c}\mathrm{Hg}_{\mathrm{T}} \\
(\mu \mathrm{g} / \mathrm{g}, \text { wet wt })\end{array}$ & $\begin{array}{c}\text { MMeHg } \\
(\mu \mathrm{g} / \mathrm{g}, \text { wet wt) }\end{array}$ & percent $\mathrm{MMeHg}$ \\
\hline HG10 & $6 / 10 / 2010$ & CR-HG10-061010-006 & Hemiptera & Gerridae & adult & 25 & 1.48 & 0.059 & 79.82 & 0.033 & 0.021 & 63.64 \\
\hline HG10 & $6 / 10 / 2010$ & CR-HG10-061010-007 & Hemiptera & Gerridae & adult & 25 & 1.45 & 0.058 & 84.47 & 0.026 & 0.020 & 78.68 \\
\hline HG11 & $6 / 17 / 2010$ & CR-HG11-061710-001 & Odonata & Libellulidae & larvae & 2 & 0.71 & 0.355 & NA & 0.061 & 0.039 & 64.27 \\
\hline HG11 & $6 / 17 / 2010$ & CR-HG11-061710-002 & Coleoptera & Dytiscidae & adult & 13 & 0.68 & 0.052 & 69.60 & 0.150 & 0.148 & 98.67 \\
\hline HG11 & $6 / 17 / 2010$ & CR-HG11-061710-003 & Odonata & Lestidae & larvae & 26 & 1.59 & 0.061 & 87.05 & 0.023 & 0.008 & 33.48 \\
\hline HG11 & $6 / 17 / 2010$ & CR-HG11-061710-004 & Odonata & Coenagrionidae & larvae & 16 & 0.64 & 0.040 & 85.60 & 0.091 & 0.018 & 19.30 \\
\hline HG11 & $6 / 17 / 2010$ & CR-HG11-061710-005 & Hemiptera & Gerridae & adult & 25 & 1.53 & 0.061 & 68.59 & 0.045 & 0.034 & 74.44 \\
\hline HG12 & $6 / 17 / 2010$ & CR-HG12-061710-001 & Coleoptera & Hydrophilidae & larvae & 4 & 1.25 & 0.313 & 86.61 & 0.022 & 0.007 & 31.36 \\
\hline HG12 & $6 / 17 / 2010$ & CR-HG12-061710-003 & Odonata & Lestidae & larvae & 17 & 0.95 & 0.056 & 87.23 & 0.018 & 0.007 & 37.08 \\
\hline HG12 & $6 / 17 / 2010$ & CR-HG12-061710-005 & Hemiptera & Gerridae & adult & 25 & 1.57 & 0.063 & 66.89 & 0.037 & 0.040 & 107.26 \\
\hline HG13 & $6 / 17 / 2010$ & CR-HG13-061710-002 & Odonata & Lestidae & larvae & 14 & 0.74 & 0.053 & 87.85 & 0.010 & 0.003 & 35.68 \\
\hline HG13 & $6 / 17 / 2010$ & CR-HG13-061710-003 & Odonata & Coenagrionidae & larvae & 15 & 0.61 & 0.041 & NA & 0.079 & 0.018 & 22.04 \\
\hline HG13 & $6 / 17 / 2010$ & CR-HG13-061710-004 & Hemiptera & Gerridae & adult & 24 & 1.4 & 0.058 & 79.81 & 0.029 & 0.023 & 79.04 \\
\hline HG14 & $6 / 17 / 2010$ & CR-HG14-061710-001 & Hemiptera & Gerridae & adult & 24 & 1.54 & 0.064 & 80.49 & 0.015 & 0.013 & 82.47 \\
\hline HG14 & $6 / 17 / 2010$ & CR-HG14-061710-003 & Odonata & Lestidae & larvae & 16 & 2.21 & 0.138 & 85.62 & 0.009 & 0.003 & 33.22 \\
\hline HG1 & $6 / 2 / 2011$ & CR-HG1-060211-001 & Coleoptera & Hydrophilidae & larvae & 5 & 0.53 & 0.106 & NA & 5.960 & 0.113 & 1.90 \\
\hline HG1 & $6 / 2 / 2011$ & CR-HG1-060211-002 & Odonata & Coenagrionidae & larvae & 30 & 1.46 & 0.049 & 80.11 & 8.800 & 0.230 & 2.61 \\
\hline HG1 & $6 / 2 / 2011$ & CR-HG1-060211-003 & Odonata & Coenagrionidae & larvae & 30 & 1.59 & 0.053 & 80.08 & 9.940 & 0.228 & 2.29 \\
\hline HG1 & $6 / 2 / 2011$ & CR-HG1-060211-004 & Coleoptera & Dytiscidae & adult & 35 & 1.29 & 0.037 & 56.35 & 1.240 & 0.267 & 21.53 \\
\hline HG2 & $6 / 2 / 2011$ & CR-HG2-060211-001 & Coleoptera & Dytiscidae & adult & 20 & 1.13 & 0.057 & 83.70 & 2.490 & 0.491 & 19.72 \\
\hline HG2 & $6 / 2 / 2011$ & CR-HG2-060211-002 & Odonata & Coenagrionidae & larvae & 25 & 1.59 & 0.064 & 78.44 & 4.500 & 0.604 & 13.42 \\
\hline $\mathrm{HG} 2 \mathrm{a}$ & $6 / 2 / 2011$ & CR-HG2a-060211-001 & Hemiptera & Gerridae & adult & 24 & 1.66 & 0.069 & 70.38 & 0.165 & 0.079 & 47.94 \\
\hline $\mathrm{HG} 2 \mathrm{a}$ & $6 / 2 / 2011$ & CR-HG2a-060211-002 & Coleoptera & Hydrophilidae & larvae & 4 & 1.1 & 0.275 & 81.30 & 0.840 & 0.078 & 9.26 \\
\hline $\mathrm{HG} 2 \mathrm{a}$ & $6 / 2 / 2011$ & CR-HG2a-060211-003 & Coleoptera & Hydrophilidae & larvae & 8 & 1.13 & 0.141 & 87.26 & 0.685 & 0.046 & 6.72 \\
\hline $\mathrm{HG} 2 \mathrm{a}$ & $6 / 2 / 2011$ & CR-HG2a-060211-004 & Coleoptera & Dytiscidae & adult & 16 & 1.11 & 0.069 & 63.41 & 0.839 & 0.213 & 25.39 \\
\hline HG3 & $6 / 2 / 2011$ & CR-HG3-060211-001 & Odonata & Coenagrionidae & larvae & 14 & 0.62 & 0.044 & 80.57 & 0.053 & 0.024 & 44.01 \\
\hline HG3 & $6 / 2 / 2011$ & CR-HG3-060211-002 & Odonata & Lestidae & larvae & 29 & 1.13 & 0.039 & 86.52 & 0.020 & 0.014 & 71.50 \\
\hline HG3 & $6 / 2 / 2011$ & CR-HG3-060211-003 & Coleoptera & Hydrophilidae & larvae & 10 & 1.09 & 0.109 & 83.22 & 0.019 & 0.010 & 50.52 \\
\hline HG3 & $6 / 2 / 2011$ & CR-HG3-060211-004 & Odonata & Aeshnidae & larvae & 4 & 3.96 & 0.990 & 72.72 & 0.038 & 0.023 & 60.37 \\
\hline HG3 & $6 / 2 / 2011$ & CR-HG3-060211-005 & Odonata & Libellulidae & larvae & 5 & 2.47 & 0.494 & 77.61 & 0.039 & 0.027 & 68.48 \\
\hline HG3 & $6 / 2 / 2011$ & CR-HG3-060211-006 & Coleoptera & Dytiscidae & adult & 20 & 1.47 & 0.074 & 62.63 & 0.242 & 0.109 & 45.04 \\
\hline HG3 & $6 / 2 / 2011$ & CR-HG3-060211-007 & Hemiptera & Gerridae & adult & 26 & 1.66 & 0.064 & 71.05 & 0.051 & 0.034 & 66.21 \\
\hline HG4 & $6 / 2 / 2011$ & CR-HG4-060211-001 & Odonata & Aeshnidae & larvae & 2 & 1.99 & 0.995 & 72.82 & 0.814 & 0.520 & 63.88 \\
\hline HG4 & $6 / 2 / 2011$ & CR-HG4-060211-002 & Odonata & Libellulidae & larvae & 8 & 3.87 & 0.484 & 80.25 & 0.355 & 0.129 & 36.34 \\
\hline
\end{tabular}


Table 9 (continued). Total mercury $\left(\mathrm{Hg}_{\mathrm{T}}\right)$ and monomethyl mercury $(\mathrm{MMeHg})(\mu \mathrm{g} / \mathrm{g}$, wet wt) in individual composites of invertebrates collected at Harley Gulch in 2002, 2007, 2008, 2010 and 2011, and at a reference site, Bear River at Highway 20 (BR 20), during 1999-2002.

\begin{tabular}{|c|c|c|c|c|c|c|c|c|c|c|c|c|}
\hline Site-Year & $\begin{array}{c}\text { Date } \\
\text { collected }\end{array}$ & Sample number & Order & Family & Age & $\mathrm{N}$ & Mass $(\mathrm{g})$ & Ave. Mass (g) & $\begin{array}{c}\text { Moisture ( } \\
\text { percent) }\end{array}$ & $\begin{array}{c}\mathrm{Hg}_{\mathrm{T}} \\
(\mu \mathrm{g} / \mathrm{g} \text {, wet wt) } \\
\end{array}$ & $\begin{array}{c}\mathrm{MMeHg} \\
(\mu \mathrm{g} / \mathrm{g}, \text { wet } w \mathrm{t}) \\
\end{array}$ & percent $\mathrm{MMeHg}$ \\
\hline HG4 & $6 / 2 / 2011$ & CR-HG4-060211-003 & Odonata & Coenagrionidae & larvae & 20 & 1.09 & 0.055 & 79.86 & 0.870 & 0.101 & 11.61 \\
\hline HG4 & $6 / 2 / 2011$ & CR-HG4-060211-004 & Odonata & Lestidae & larvae & 25 & 1.39 & 0.056 & 81.33 & 0.363 & 0.094 & 25.81 \\
\hline HG4 & $6 / 2 / 2011$ & CR-HG4-060211-005 & Coleoptera & Dytiscidae & adult & 19 & 1.74 & 0.092 & 66.96 & 0.667 & 0.275 & 41.23 \\
\hline HG4 & $6 / 10 / 2011$ & CR-HG4-061011-006 & Hemiptera & Gerridae & adult & 25 & 1.62 & 0.065 & 67.88 & 0.246 & 0.132 & 53.66 \\
\hline HG5 & $6 / 2 / 2011$ & CR-HG5-060211-001 & Odonata & Coenagrionidae & larvae & 25 & 1.45 & 0.058 & 82.04 & 0.747 & 0.214 & 28.65 \\
\hline HG5 & $6 / 2 / 2011$ & CR-HG5-060211-002 & Odonata & Coenagrionidae & larvae & 25 & 1.58 & 0.063 & 81.21 & 0.710 & 0.225 & 31.69 \\
\hline HG5 & $6 / 2 / 2011$ & CR-HG5-060211-003 & Odonata & Aeshnidae & larvae & 4 & 2.95 & 0.738 & 79.01 & 0.435 & 0.170 & 39.08 \\
\hline HG5 & $6 / 2 / 2011$ & CR-HG5-060211-004 & Odonata & Libellulidae & larvae & 4 & 1.64 & 0.410 & 79.55 & 0.308 & 0.114 & 37.01 \\
\hline HG5 & $6 / 2 / 2011$ & CR-HG5-060211-005 & Coleoptera & Dytiscidae & adult & 14 & 1.31 & 0.094 & 70.76 & 0.326 & 0.169 & 51.84 \\
\hline HG5 & $6 / 10 / 2011$ & CR-HG5-061011-006 & Hemiptera & Gerridae & adult & 25 & 1.64 & 0.066 & 71.87 & 0.228 & 0.131 & 57.46 \\
\hline HG5 & $6 / 10 / 2011$ & CR-HG5-061011-007 & Hemiptera & Gerridae & adult & 25 & 1.73 & 0.069 & 69.14 & 0.282 & 0.146 & 51.77 \\
\hline HG7 & $6 / 2 / 2011$ & CR-HG7-060211-001 & Odonata & Libellulidae & larvae & 7 & 3.15 & 0.450 & 82.65 & 0.290 & 0.147 & 50.69 \\
\hline HG7 & $6 / 2 / 2011$ & CR-HG7-060211-002 & Odonata & Libellulidae & larvae & 8 & 1.77 & 0.221 & 83.86 & 0.285 & 0.137 & 48.07 \\
\hline HG7 & $6 / 2 / 2011$ & CR-HG7-060211-003 & Odonata & Libellulidae & larvae & 30 & 1.66 & 0.055 & 82.99 & 0.539 & 0.166 & 30.80 \\
\hline HG7 & $6 / 2 / 2011$ & CR-HG7-060211-004 & Hemiptera & Gerridae & adult & 25 & 1.73 & 0.069 & 72.94 & 0.215 & 0.133 & 61.86 \\
\hline
\end{tabular}

${ }^{1} \mathrm{NA}=$ not analyzed. 
Table 10. Total mercury $\left(\mathrm{Hg}_{\mathrm{T}}\right)$ and monomethyl mercury (MMeHg) ( $\mu \mathrm{g} / \mathrm{g}$, wet wt) in foothill yellow-legged frogs from Harley Gulch, Lake county, California, in 2007-2008.

\begin{tabular}{|c|c|c|c|c|c|c|c|c|}
\hline Site & $\begin{array}{l}\text { Sample } \\
\text { number }\end{array}$ & Year & Age & Sex & $\begin{array}{l}\text { Length, in } \\
\text { millimeters } \\
\end{array}$ & Mass, in grams & $\mathrm{Hg}_{\mathrm{T}}(\mu \mathrm{g} / \mathrm{g} w w)$ & $\mathrm{MMeHg}(\mu \mathrm{g} / \mathrm{g} w w)$ \\
\hline HG3 & 2056 & 2007 & Adult & Female & 30.2 & 3.31 & 0.045 & 0.059 \\
\hline HG3 & 2057 & 2007 & Juvenile & Female & 29.7 & 2.65 & 0.059 & NA \\
\hline HG4 & 2052 & 2007 & Adult & Male & 42.2 & 9.42 & 0.525 & NA \\
\hline HG4 & 2053 & 2007 & Adult & Female & 32.4 & 4.61 & 0.785 & 0.403 \\
\hline HG4 & 2054 & 2007 & Adult & Male & 36.6 & 6.11 & 0.795 & NA \\
\hline HG4 & 2055 & 2007 & Adult & Female & 63.3 & 28.03 & 1.13 & NA \\
\hline HG5 & 2049 & 2007 & Adult & Male & 49.9 & 14.86 & 1.66 & NA \\
\hline HG5 & 2050 & 2007 & Adult & Male & 36.3 & 7.18 & 0.733 & 0.351 \\
\hline HG5 & 2051 & 2007 & Adult & Male & 32.4 & 5.04 & 0.525 & NA \\
\hline HG6 & 2043 & 2007 & Adult & Female & 58.9 & 27.12 & 0.895 & NA \\
\hline HG6 & 2044 & 2007 & Adult & Male & 33.2 & 4.26 & 0.734 & 0.4 \\
\hline HG6 & 2045 & 2007 & Adult & Female & 42.6 & 8.91 & 0.568 & NA \\
\hline HG7 & 2046 & 2007 & Adult & Female & 44.1 & 10.54 & 0.616 & NA \\
\hline HG7 & 2047 & 2007 & Adult & Male & 37.1 & 5.65 & 1.07 & 0.523 \\
\hline HG7 & 2048 & 2007 & Adult & Female & 35.1 & 4.55 & 1.18 & NA \\
\hline HG5 & 2075 & 2008 & Adult & Female & 44.40 & 10.98 & $\mathrm{NA}^{1}$ & 0.468 \\
\hline HG8 & 2076 & 2008 & Adult & Male & 44.06 & 10.19 & NA & 0.467 \\
\hline HG8 & 2077 & 2008 & Adult & Male & 38.05 & 8.23 & NA & 0.432 \\
\hline HG9 & 2078 & 2008 & Adult & Female & 44.19 & 10.41 & NA & 0.263 \\
\hline HG10 & 2079 & 2008 & Adult & Female & 45.98 & 14.12 & NA & 0.135 \\
\hline HG11 & 2080 & 2008 & Adult & Male & 44.73 & 12.34 & NA & 0.189 \\
\hline HG13 & 2081 & 2008 & Adult & Female & 62.29 & 31.28 & NA & 0.152 \\
\hline
\end{tabular}

${ }^{1} \mathrm{NA}=$ Not analyzed 
Table 11. Total mercury $\left(\mathrm{Hg}_{\mathrm{T}}\right)(\mu \mathrm{g} / \mathrm{g}$, wet wt) in foothill yellow-legged frogs from Harley Gulch and reference sites, $1997-1998$.

\begin{tabular}{|c|c|c|c|c|c|c|c|c|}
\hline $\begin{array}{c}\text { Site/ } \\
\text { sample no. }\end{array}$ & $\begin{array}{c}\text { Collection } \\
\text { date }\end{array}$ & $\begin{array}{l}\text { Latitude/ } \\
\text { Longitude }\end{array}$ & Age & Sex & $\begin{array}{l}\text { Length, } \\
\text { in } \\
\text { millimet } \\
\text { ers } \\
\end{array}$ & $\begin{array}{l}\text { Mass, } \\
\text { in } \\
\text { grams }\end{array}$ & Site Description & $\mathbf{H g}_{\mathrm{T}}$ \\
\hline EFMC/1005 & $5 / 14 / 97$ & $\begin{array}{l}39^{\circ} \mathrm{N} 15^{\prime} 09^{\prime \prime} / \\
122^{\circ} \mathrm{W} 57^{\prime} 00^{\prime \prime}\end{array}$ & Adult & Female & 74.7 & 47.1 & East Fork Middle Creek & 0.120 \\
\hline EFMC/1004 & $5 / 14 / 97$ & $\begin{array}{l}39^{\circ} \mathrm{N} 15^{\prime} 09^{\prime \prime} / \\
122^{\circ} \mathrm{W} 57^{\prime} 00^{\prime \prime}\end{array}$ & Adult & Female & 60.9 & 30.3 & East Fork Middle Creek & 0.079 \\
\hline EFMC/1003 & $5 / 14 / 97$ & $\begin{array}{l}39^{\circ} \mathrm{N} 15^{\prime} 09^{\prime \prime} / \\
122^{\circ} \mathrm{W} 57^{\prime} 00^{\prime \prime}\end{array}$ & Adult & Male & 53.7 & 19.3 & East Fork Middle Creek & 0.055 \\
\hline BRIM/927 & $4 / 11 / 97$ & $\begin{array}{l}39^{\circ} \mathrm{N} 09^{\prime} 45^{\prime \prime} / \\
122^{\circ} \mathrm{W} 26^{\prime} 59^{\prime \prime}\end{array}$ & Adult & Female & 61.7 & 33.8 & Mill Creek at Brim Road & 0.103 \\
\hline BRIM/929 & $4 / 11 / 97$ & $\begin{array}{l}39^{\circ} \mathrm{N} 09^{\prime} 45^{\prime \prime} / \\
122^{\circ} \mathrm{W} 26^{\prime} 59^{\prime \prime}\end{array}$ & Adult & Female & 50.7 & 17.0 & Mill Creek at Brim Road & 0.081 \\
\hline BRIM/928 & $4 / 11 / 97$ & $\begin{array}{l}39^{\circ} \mathrm{N} 09^{\prime} 45^{\prime \prime} / \\
122^{\circ} \mathrm{W} 26^{\prime} 59^{\prime \prime}\end{array}$ & Adult & Female & 54.2 & 18.1 & Mill Creek at Brim Road & 0.066 \\
\hline SPCR/1001 & $5 / 12 / 97$ & $\begin{array}{l}39^{\circ} \mathrm{N} 10^{\prime} 17^{\prime \prime} / \\
122^{\circ} \mathrm{W} 37^{\prime} 05^{\prime \prime}\end{array}$ & Adult & Female & 56.4 & 20.7 & Spanish Creek & 0.089 \\
\hline SPCR/1002 & $5 / 12 / 97$ & $\begin{array}{l}39^{\circ} \mathrm{N} 10^{\prime} 17^{\prime \prime} / \\
122^{\circ} \mathrm{W} 37^{\prime \prime} 05^{\prime \prime}\end{array}$ & Adult & Female & 57.1 & 26.7 & Spanish Creek & 0.068 \\
\hline $\mathrm{SPCR} / 1000$ & $5 / 12 / 97$ & $\begin{array}{l}39^{\circ} \mathrm{N} 10^{\prime} 17^{\prime \prime} / \\
122^{\circ} \mathrm{W} 37^{\prime} 05^{\prime \prime}\end{array}$ & Adult & Female & 43.2 & 7.6 & Spanish Creek & 0.057 \\
\hline TRKY/926 & $3 / 27 / 97$ & $\begin{array}{l}39^{\circ} \mathrm{N} 00^{\prime} 57^{\prime \prime} / \\
122^{\circ} \mathrm{W} 26^{\prime} 26^{\prime \prime}\end{array}$ & Adult & Female & 47.8 & 13.4 & Turkey Run Mine & 0.793 \\
\hline HGDS/963 & $4 / 25 / 97$ & $\begin{array}{l}39^{\circ} \mathrm{N} 00^{\prime} 34^{\prime \prime} / \\
122^{\circ} \mathrm{W} 26^{\prime} 05^{\prime \prime}\end{array}$ & Adult & Female & 47.2 & 11.8 & Lower Harley Gulch & 0.583 \\
\hline HGDS/961 & $4 / 25 / 97$ & $\begin{array}{l}39^{\circ} \mathrm{N} 00^{\prime} 34^{\prime \prime} / \\
122^{\circ} \mathrm{W} 26^{\prime} 05^{\prime \prime}\end{array}$ & Adult & Male & 41.9 & 9.4 & Lower Harley Gulch & 0.419 \\
\hline HGDS/962 & $4 / 25 / 97$ & $\begin{array}{l}39^{\circ} \mathrm{N} 00^{\prime} 34^{\prime \prime} / \\
122^{\circ} \mathrm{W} 26^{\prime} 05^{\prime \prime}\end{array}$ & Adult & Male & 36.4 & 6.2 & Lower Harley Gulch & 0.355 \\
\hline ABBT/1201 & $3 / 16 / 98$ & $\begin{array}{l}39^{\circ} \mathrm{N} 00^{\prime} 56^{\prime \prime} / \\
122^{\circ} \mathrm{W} 26^{\prime} 29^{\prime \prime}\end{array}$ & Adult & Male & 56.0 & 23.4 & Abbott Drain & 1.680 \\
\hline HGDS/1190 & $3 / 11 / 98$ & $\begin{array}{l}39^{\circ} \mathrm{N} 00^{\prime} 34^{\prime \prime} / \\
122^{\circ} \mathrm{W} 26^{\prime} 05^{\prime \prime}\end{array}$ & Adult & Male & 54.3 & 23.1 & Lower Harley Gulch & 1.130 \\
\hline
\end{tabular}


Table 12. Total mercury $\left(\mathrm{Hg}_{\mathrm{T}}\right)$ and monomethyl mercury (MMeHg) $(\mu \mathrm{g} / \mathrm{g}$, wet wt) in California Roach (Hesperoleucus symmetricus) frogs from site HG8a, fish pond, collected on June 10, 2010, Harley Gulch, Lake County, California.

\begin{tabular}{|c|c|c|c|c|c|c|c|c|}
\hline Sample ID & $\begin{array}{c}\text { Total } \\
\text { Length, in } \\
\text { millimeters }\end{array}$ & $\begin{array}{c}\text { Standard } \\
\text { Length, in } \\
\text { millimeters }\end{array}$ & $\begin{array}{l}\text { Mass, in } \\
\text { grams }\end{array}$ & $\begin{array}{l}\text { Sample } \\
\text { mass, in } \\
\text { grams }\end{array}$ & $\begin{array}{c}\mathrm{Hg}_{\mathrm{T}} \\
(\mu \mathrm{g} / \mathrm{g}, \mathrm{ww}) \\
\end{array}$ & $\begin{array}{c}\text { MMeHg } \\
(\mu \mathrm{g} / \mathrm{g}, \mathrm{ww})\end{array}$ & $\begin{array}{c}\text { percent } \\
\text { Moisture } \\
\end{array}$ & $\begin{array}{c}\text { percent } \\
\mathrm{MMeHg}\end{array}$ \\
\hline CR-HG8a-061010-001F & 76 & 61 & 5.2 & 4.01 & 0.362 & 0.352 & 81.74 & 97.2 \\
\hline CR-HG8a-061010-002F & 64 & 51 & 3.12 & 2.55 & 0.414 & 0.356 & 82.45 & 86.0 \\
\hline CR-HG8a-061010-003F & 63 & 51 & 3.25 & 2.75 & 0.28 & 0.237 & 80.28 & 84.6 \\
\hline CR-HG8a-061010-004F & 62 & 50 & 2.36 & 1.86 & 0.335 & 0.307 & 83.68 & 91.6 \\
\hline CR-HG8a-061010-005F & 58 & 46 & 2.5 & 1.49 & 0.275 & 0.343 & 86.05 & 124.7 \\
\hline CR-HG8a-061010-006F & 55 & 44 & 2.26 & 1.48 & 0.264 & 0.173 & 86.30 & 65.5 \\
\hline CR-HG8a-061010-007F & 60 & 49 & 2.03 & 1.71 & 0.382 & 0.334 & 84.29 & 87.4 \\
\hline
\end{tabular}




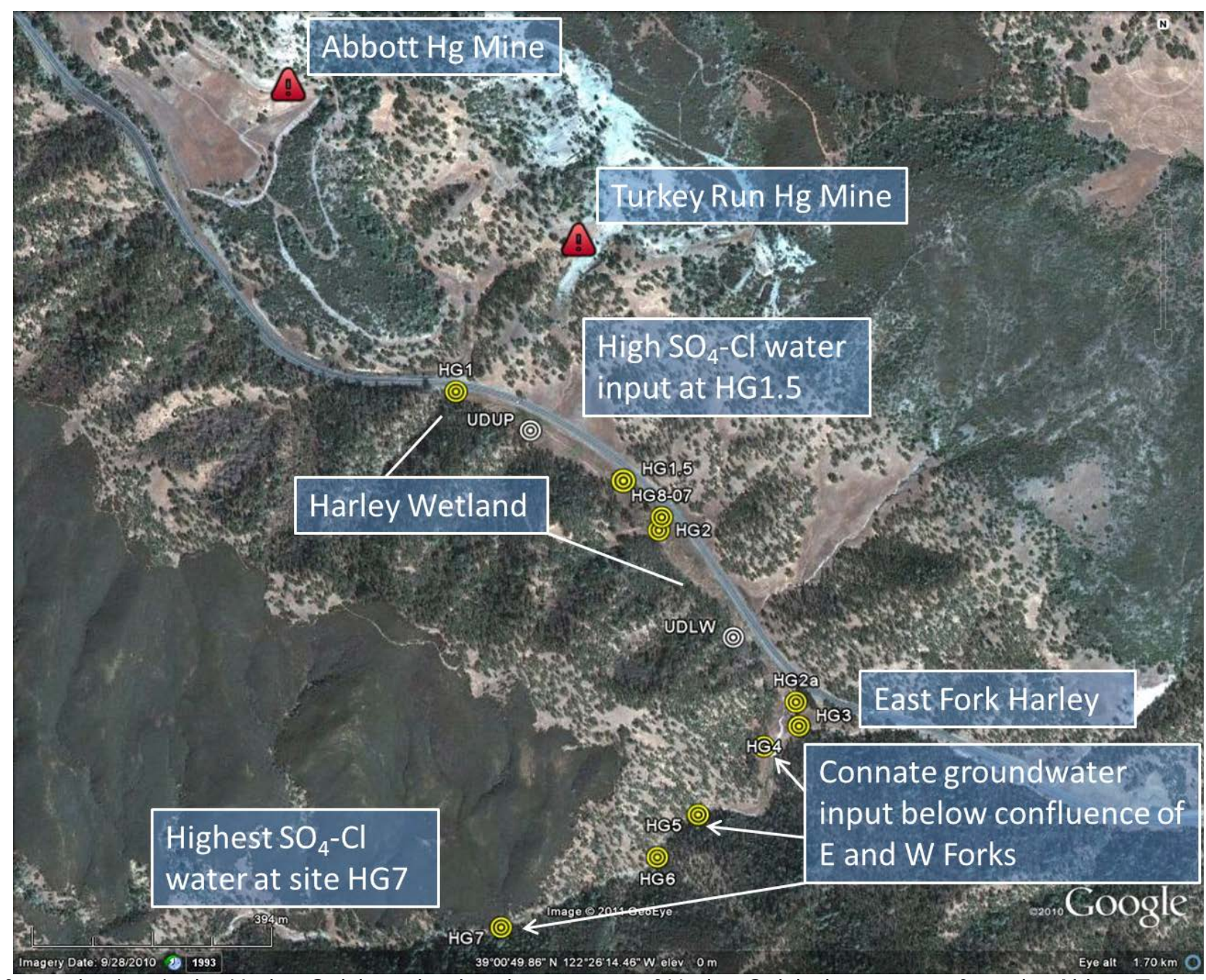

Figure 1. Location of sample sites in the Harley Gulch wetland and upper part of Harley Gulch downstream from the Abbott-Turkey Run mine, Lake County, California. Connate groundwater input occurs in the central part of the wetland at sample site HG1.5 and in the upper part of Harley Gulch between sample sites HG 4 and HG7. 


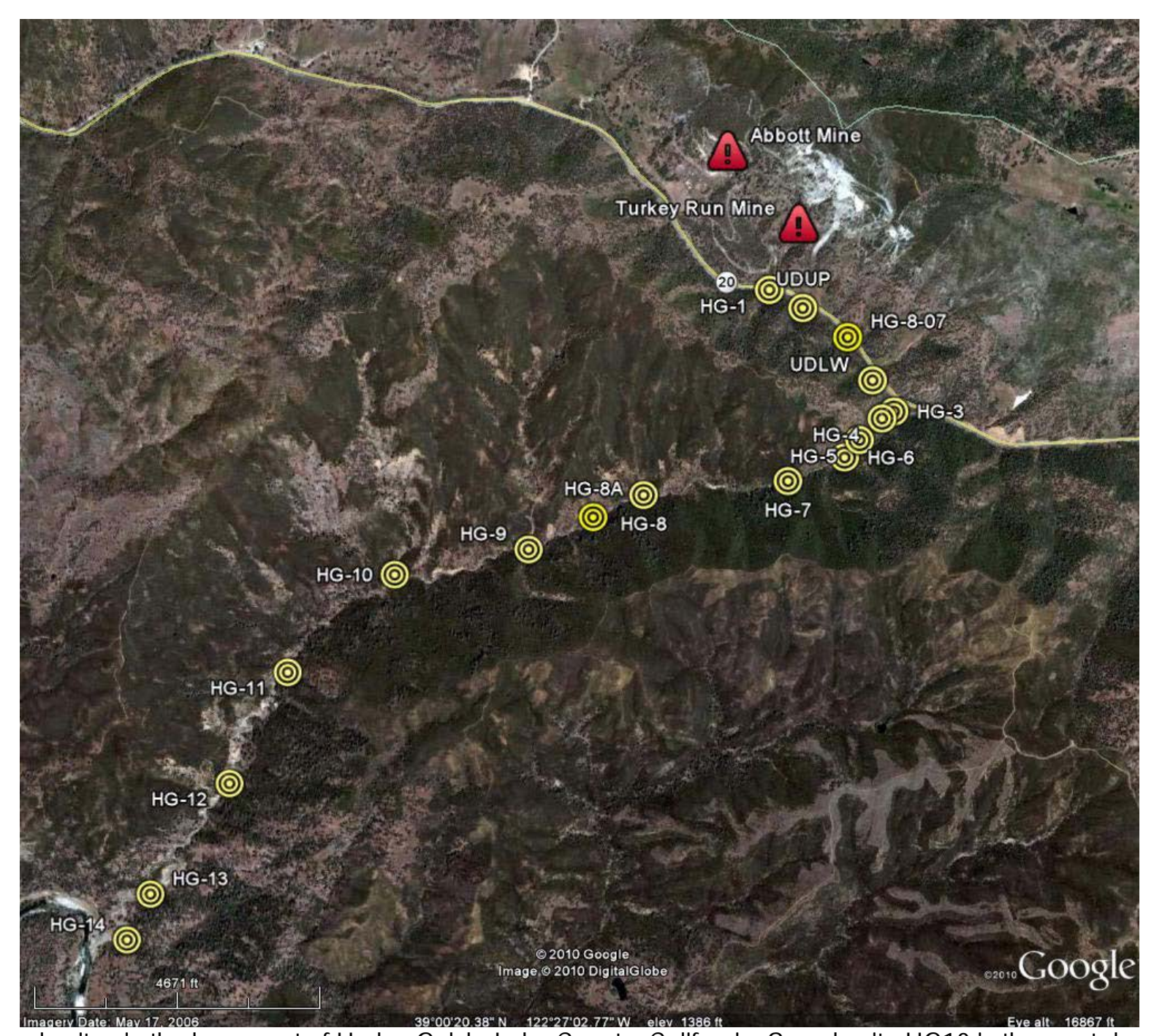

Figure 2. Location of sample sites in the lower part of Harley Gulch, Lake County, California. Sample site HG10 is the most downstream water and sediment site sampled; see fig. 1 for locations of sites 2 and $2 a$. 


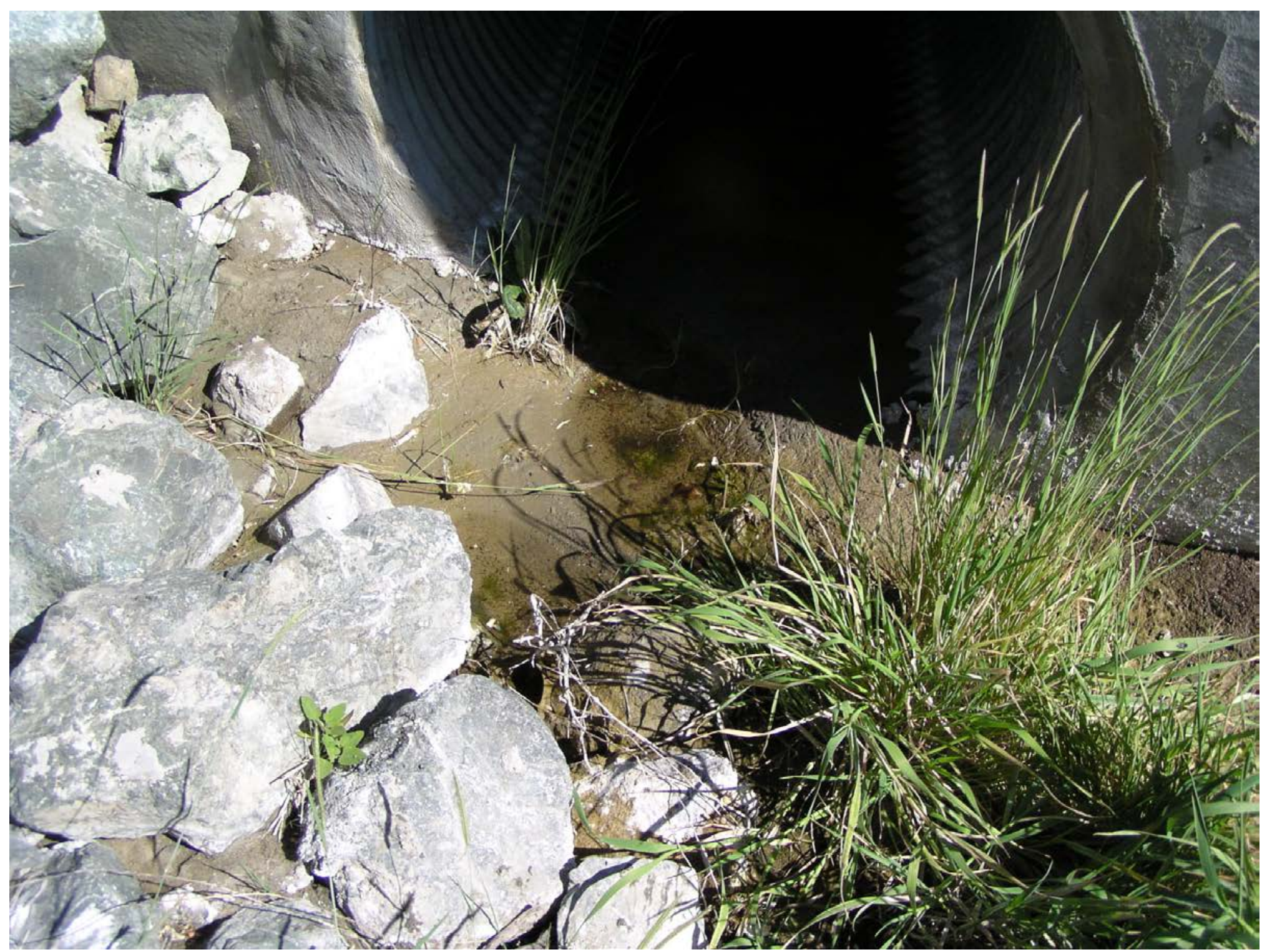

Figure 3. Sample site HG1, Harley Gulch, Lake County, California, just downstream from Highway 20. 


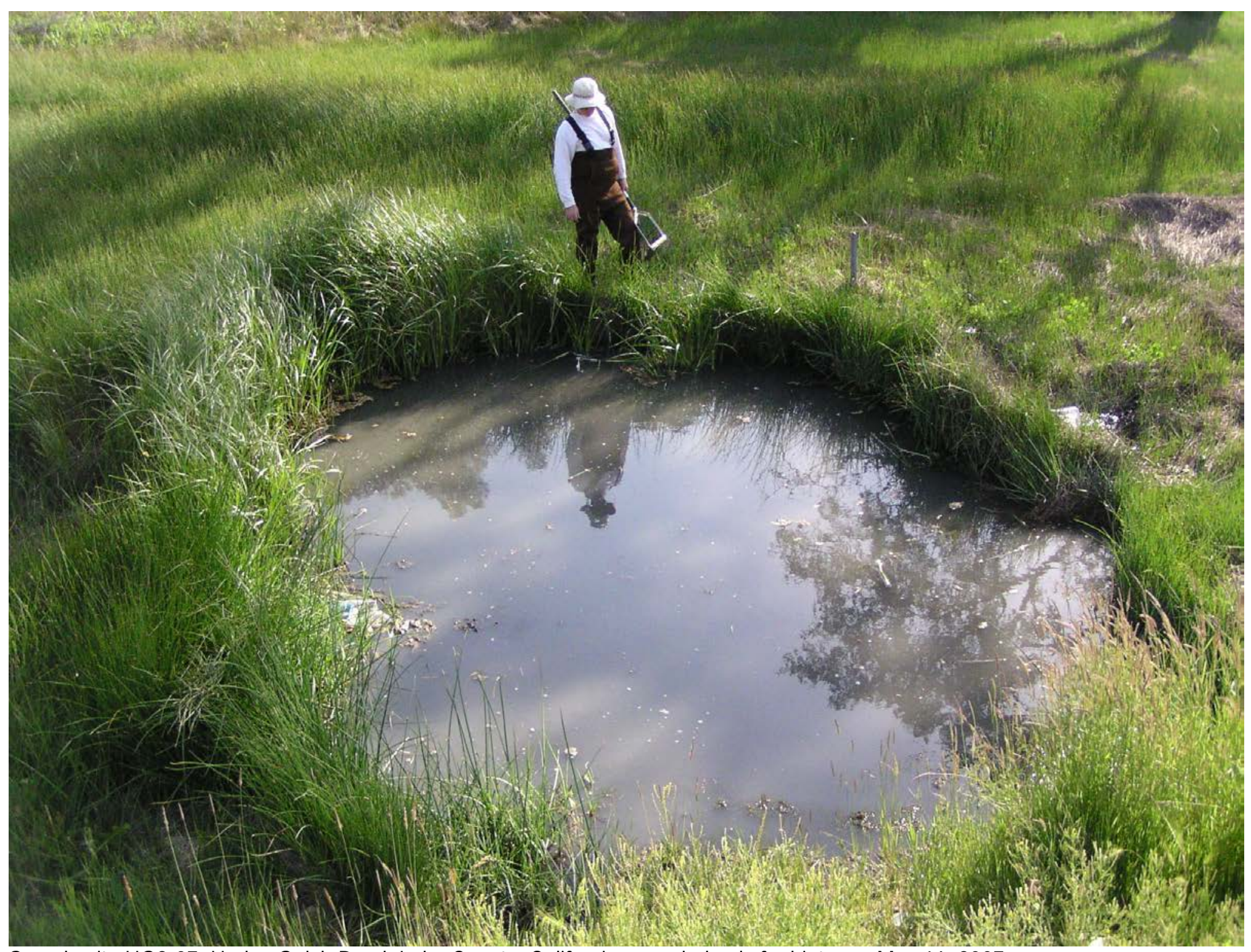

Figure 4. Sample site HG8-07, Harley Gulch Pond, Lake County, California, sampled only for biota on May 16, 2007. 


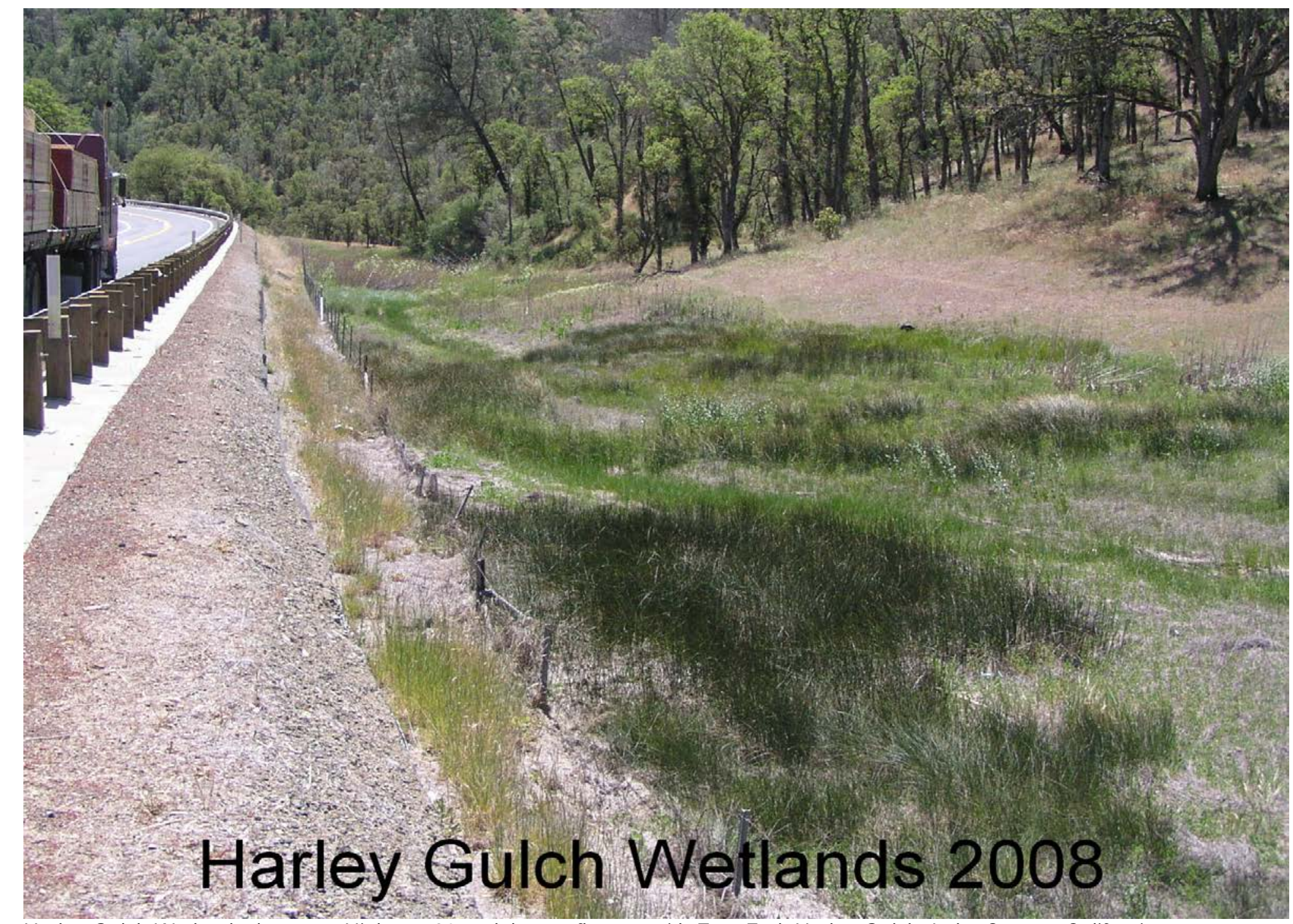

Figure 5. Harley Gulch Wetlands, between Highway 20 and the confluence with East Fork Harley Gulch, Lake County, California. 

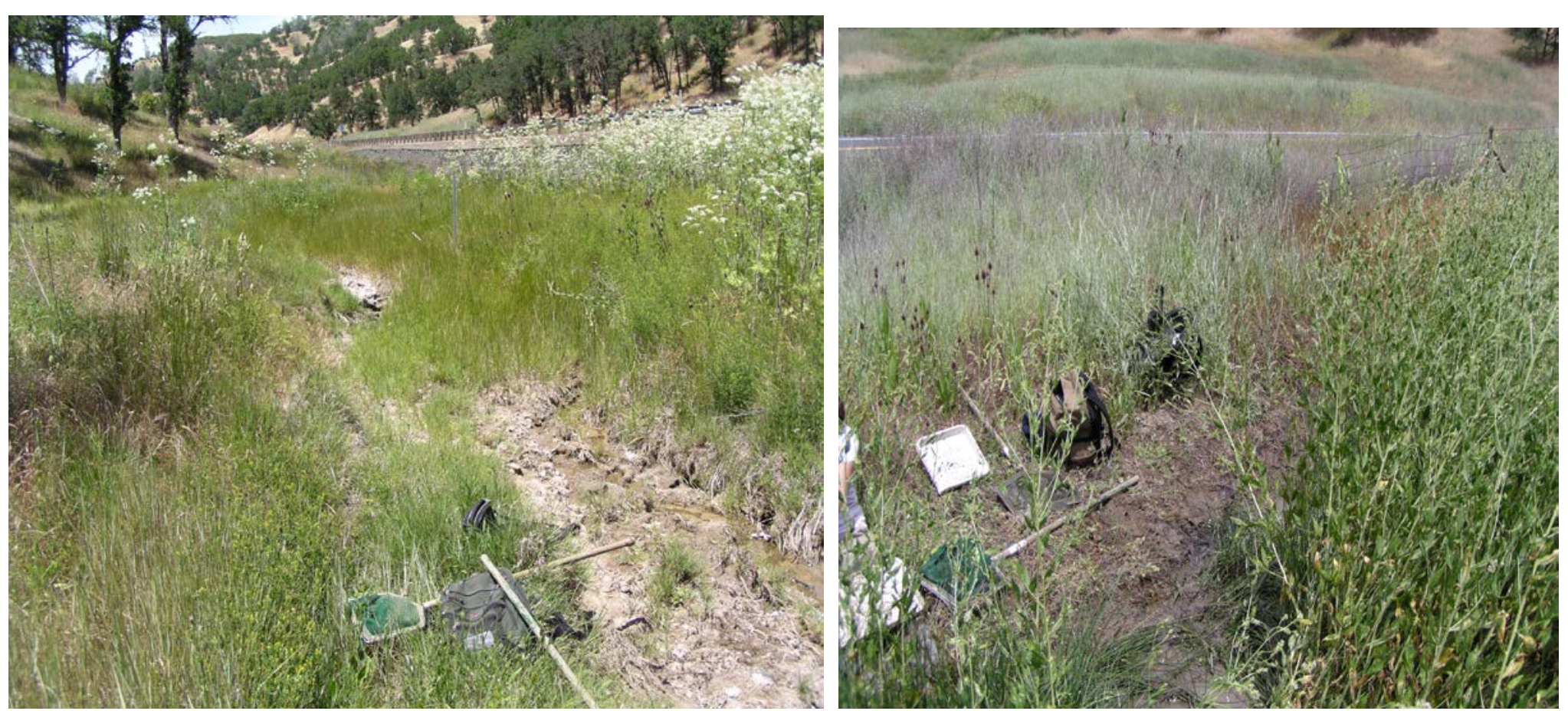

Figure 6. Harley Gulch Wetlands sites, UDLW (left) and UDUP (right) sampled for biota only on June 10, 2010, Lake County, California. 


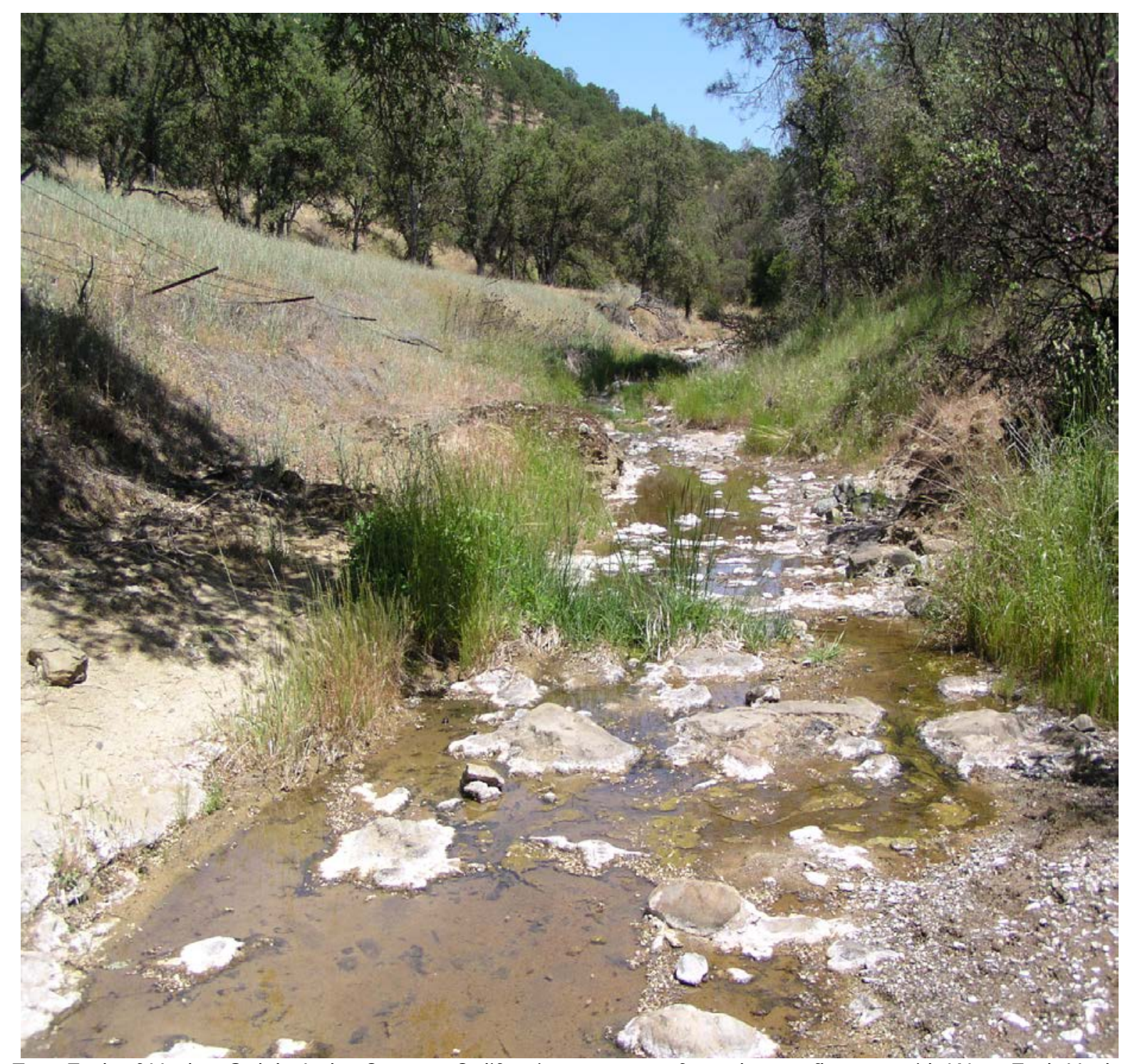

Figure 7. Sample site HG3, East Fork of Harley Gulch, Lake County, California, upstream from the confluence with West Fork Harley Gulch. 


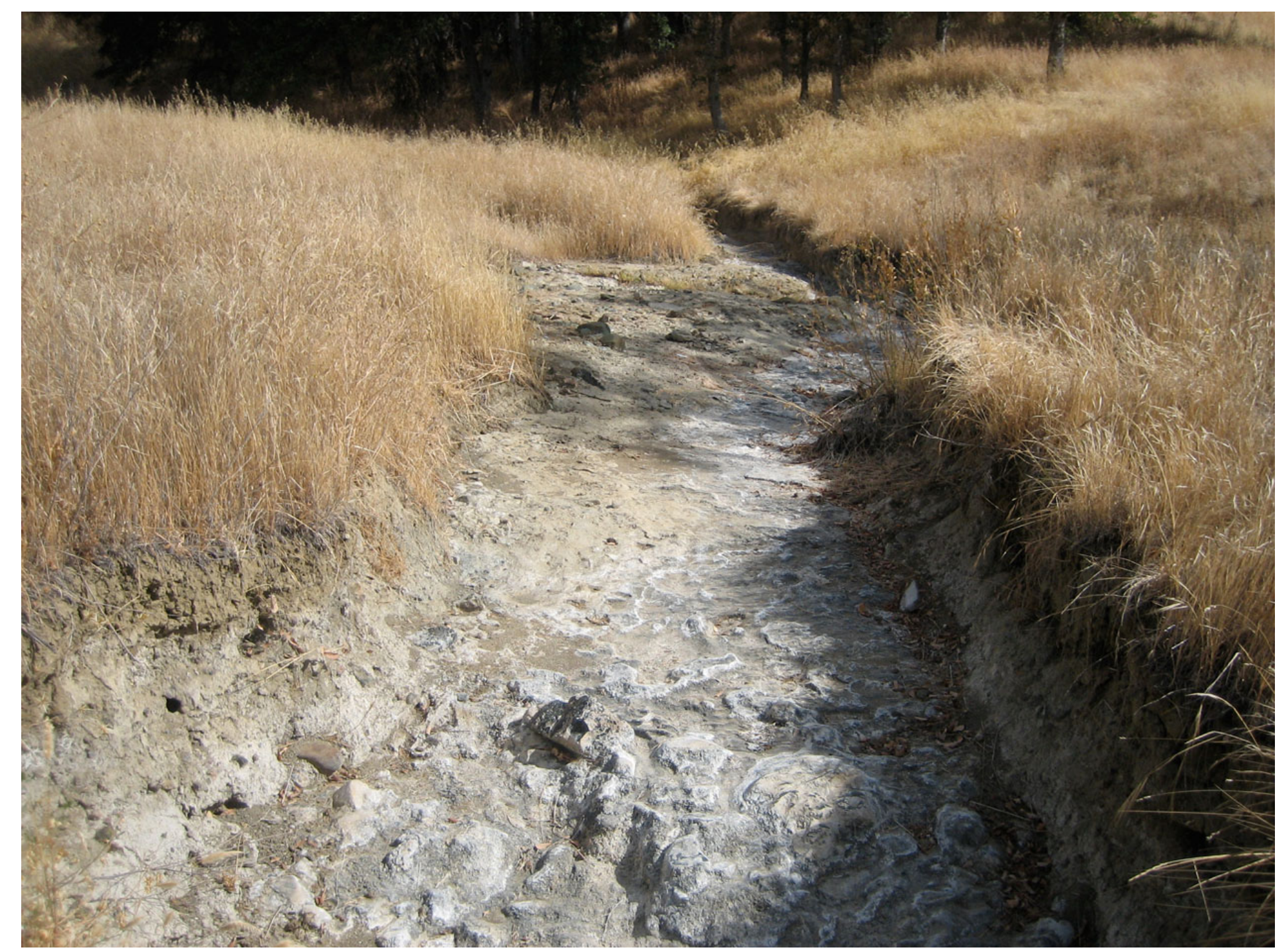

Figure 8. West Fork of Harley Gulch, Lake County, California at sample site HG 2 downstream from wetland area. Sediment in creek bed is cemented by $\mathrm{CaCO}_{3}$ 


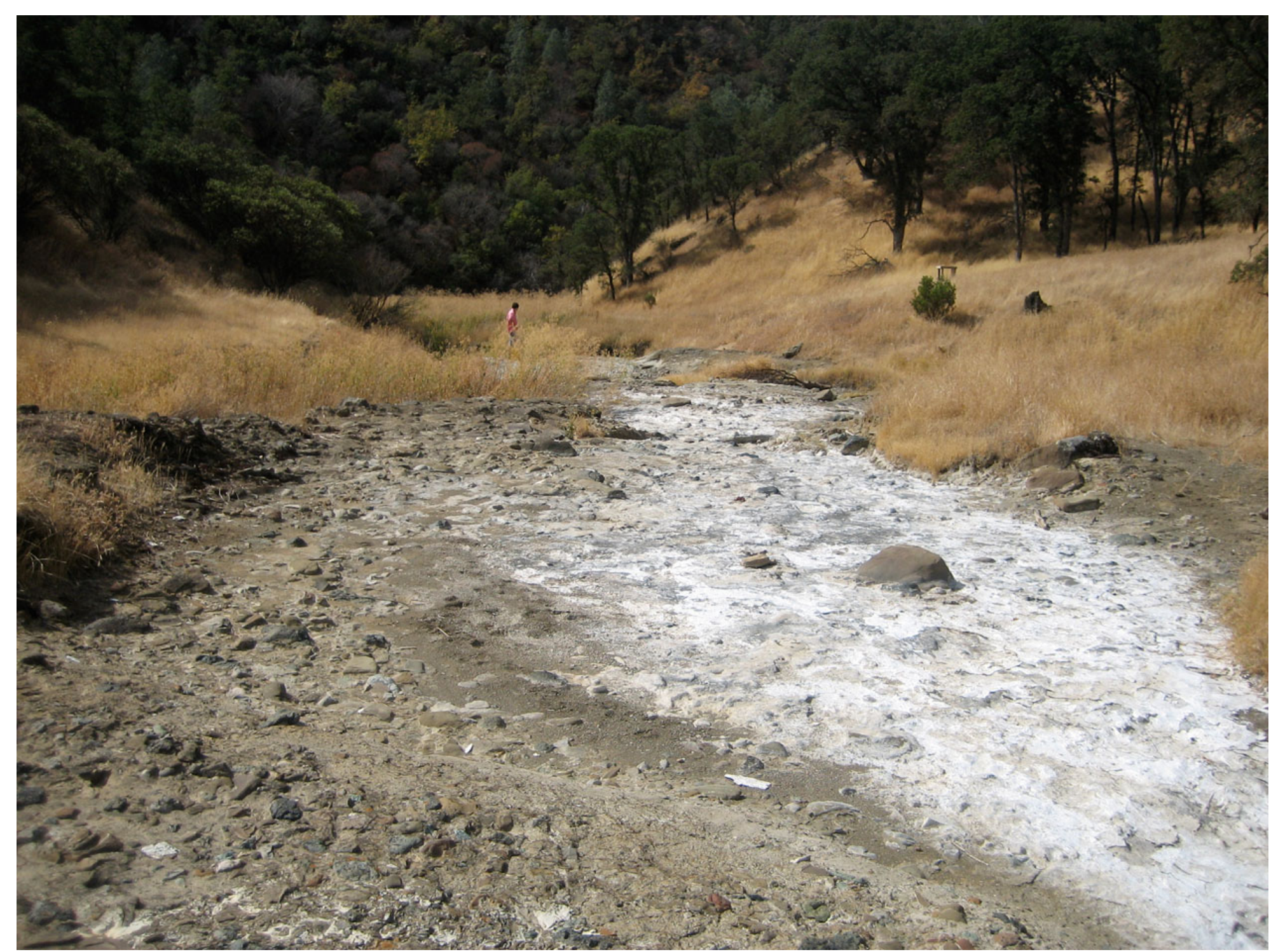

Figure 9. West Fork of Harley Gulch looking downstream from sample site HG2 toward sample site HG4 (location of geologist), Lake County, California. Creek bed is covered by efflorescent salts (white area) and sediment deposited from a high-flow event. 


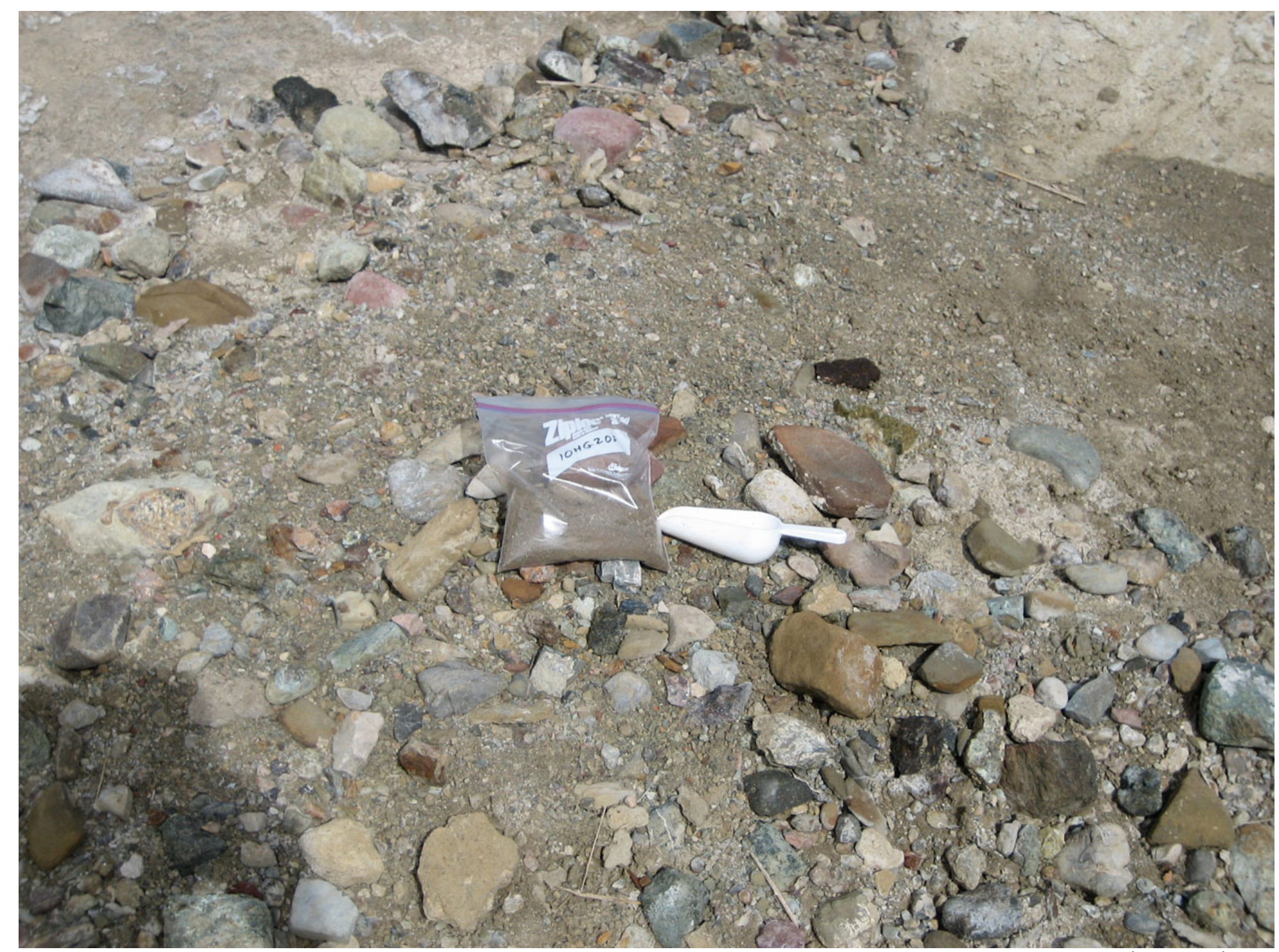

Figure 10. Coarse pebble sand at site HG2, deposited during high-flow events in the winter of 2010, has high Hg concentration(136 $\mu \mathrm{g} / \mathrm{g}) \mathrm{because}$ of erosion of tailings and $\mathrm{Hg}$-enriched soils from the Abbott-Turkey Run mine, Lake County, California. 


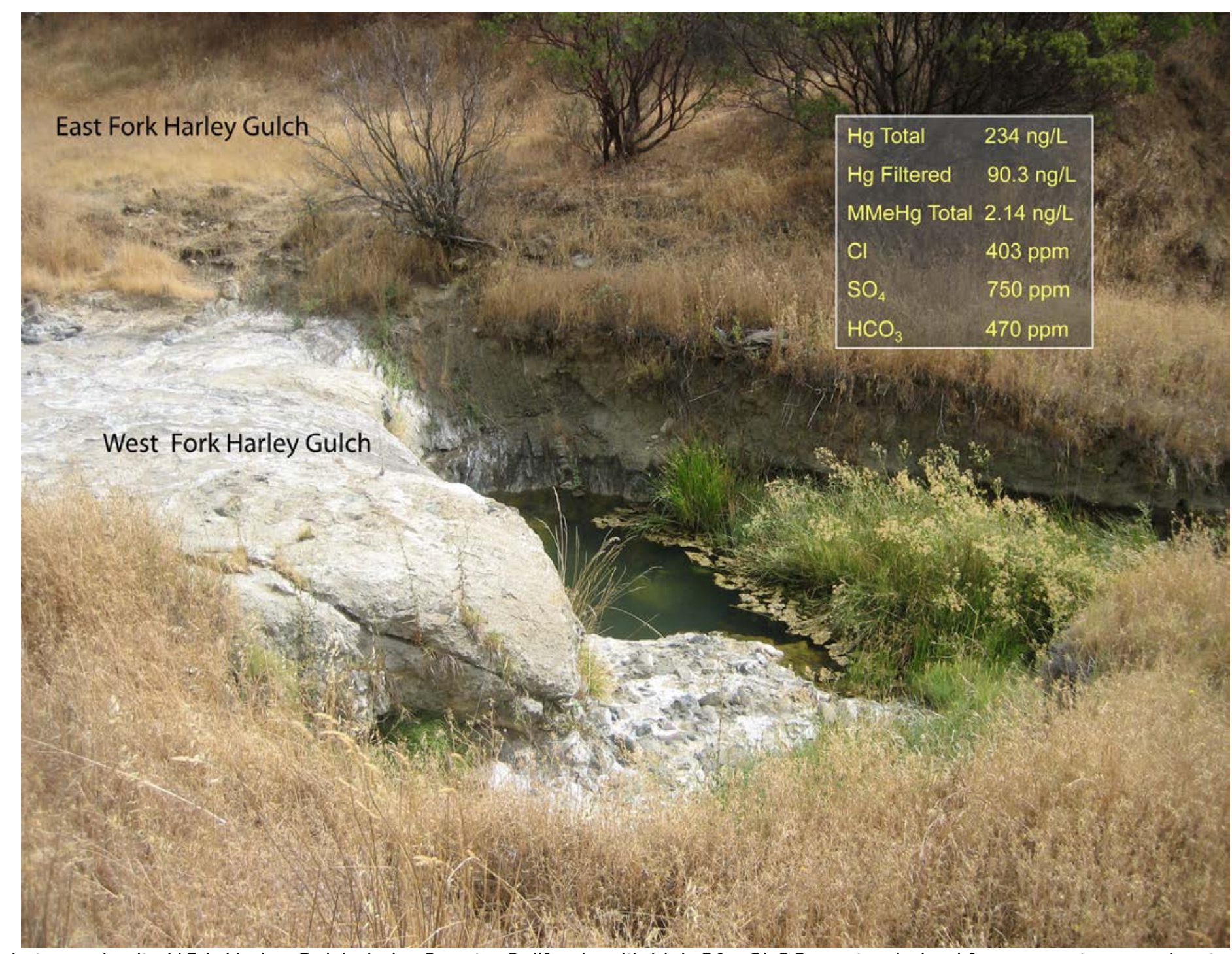

Figure 11. Pool at sample site HG4, Harley Gulch, Lake County, California with high $\mathrm{SO}_{4}-\mathrm{Cl}_{-} \mathrm{CO}_{3}$ water derived from connate ground water. Water has high total mercury $\left(\mathrm{Hg}_{\mathrm{T}}\right)$ and filtered mercury $\left(\mathrm{Hg}_{\mathrm{F}}\right)$. 


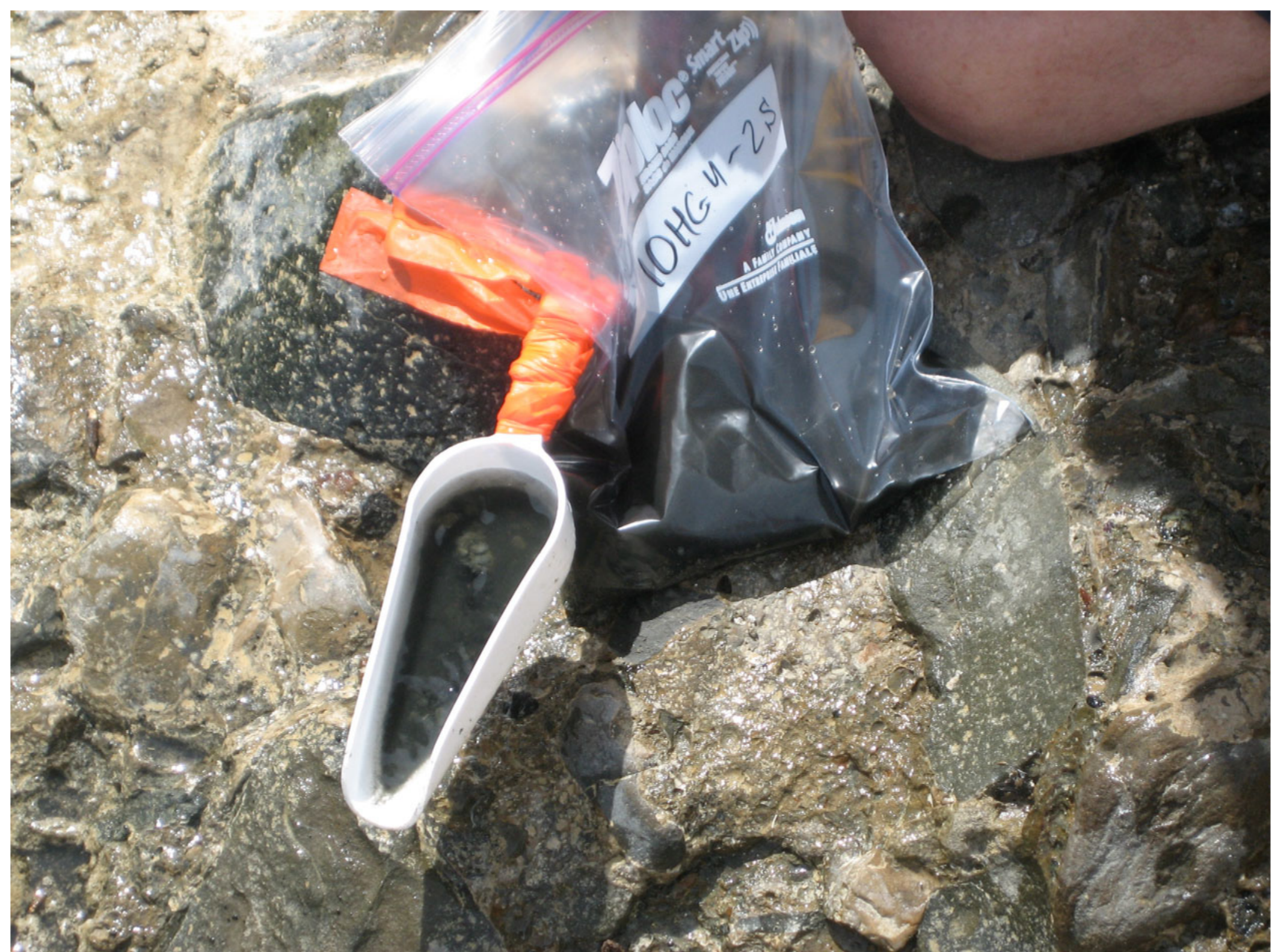

Figure 12. Black reduced sediment at bottom of pool at site HG4, Harley Gulch, Lake County, California, consisting of biogenic and clastic sediment with high $\mathrm{Hg}$ concentration $(23.9 \mu \mathrm{g} / \mathrm{g})$. 


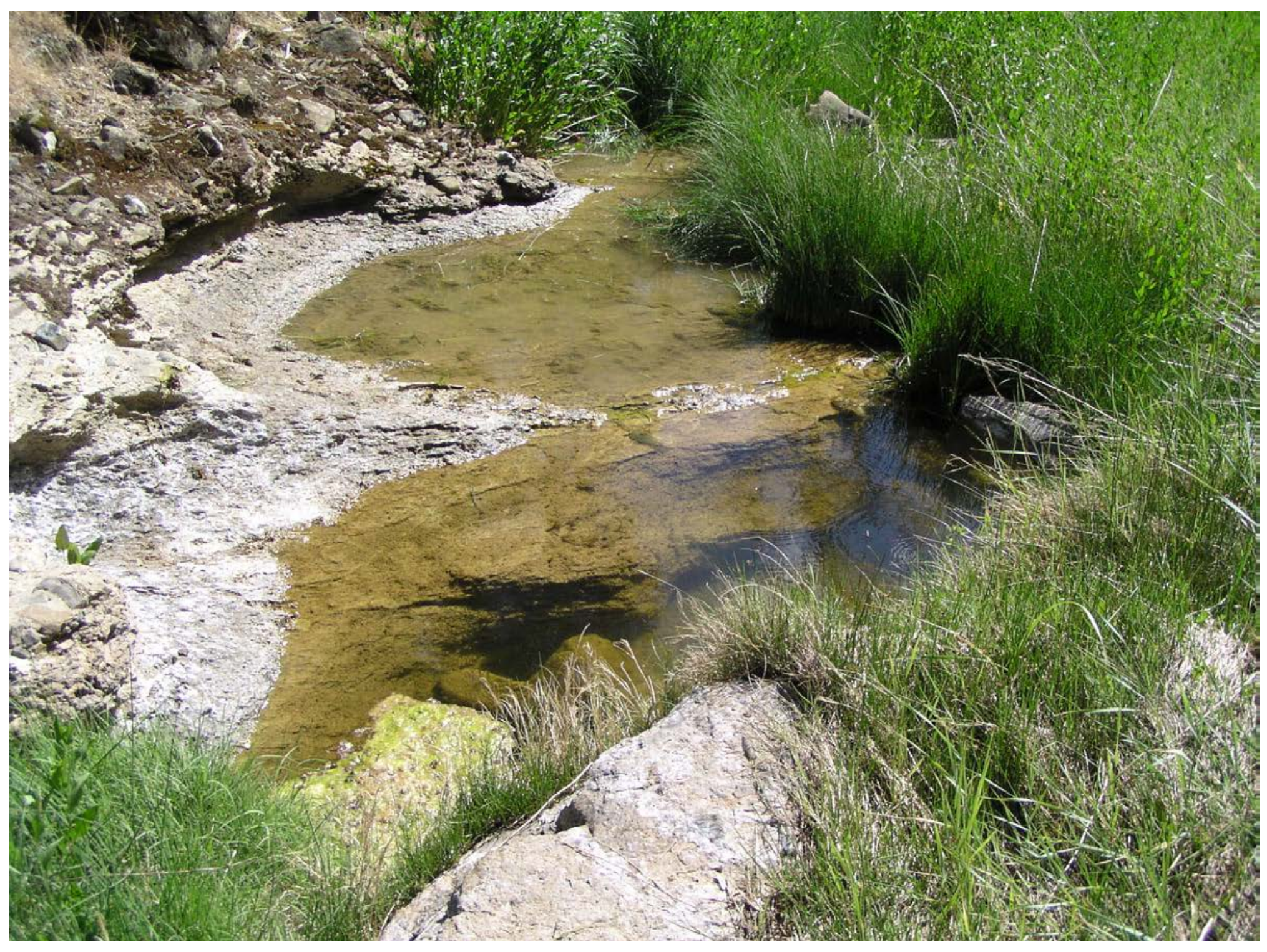

Figure 13. Sample site HG5 in the West Fork of Harley Gulch, Lake County, California. 


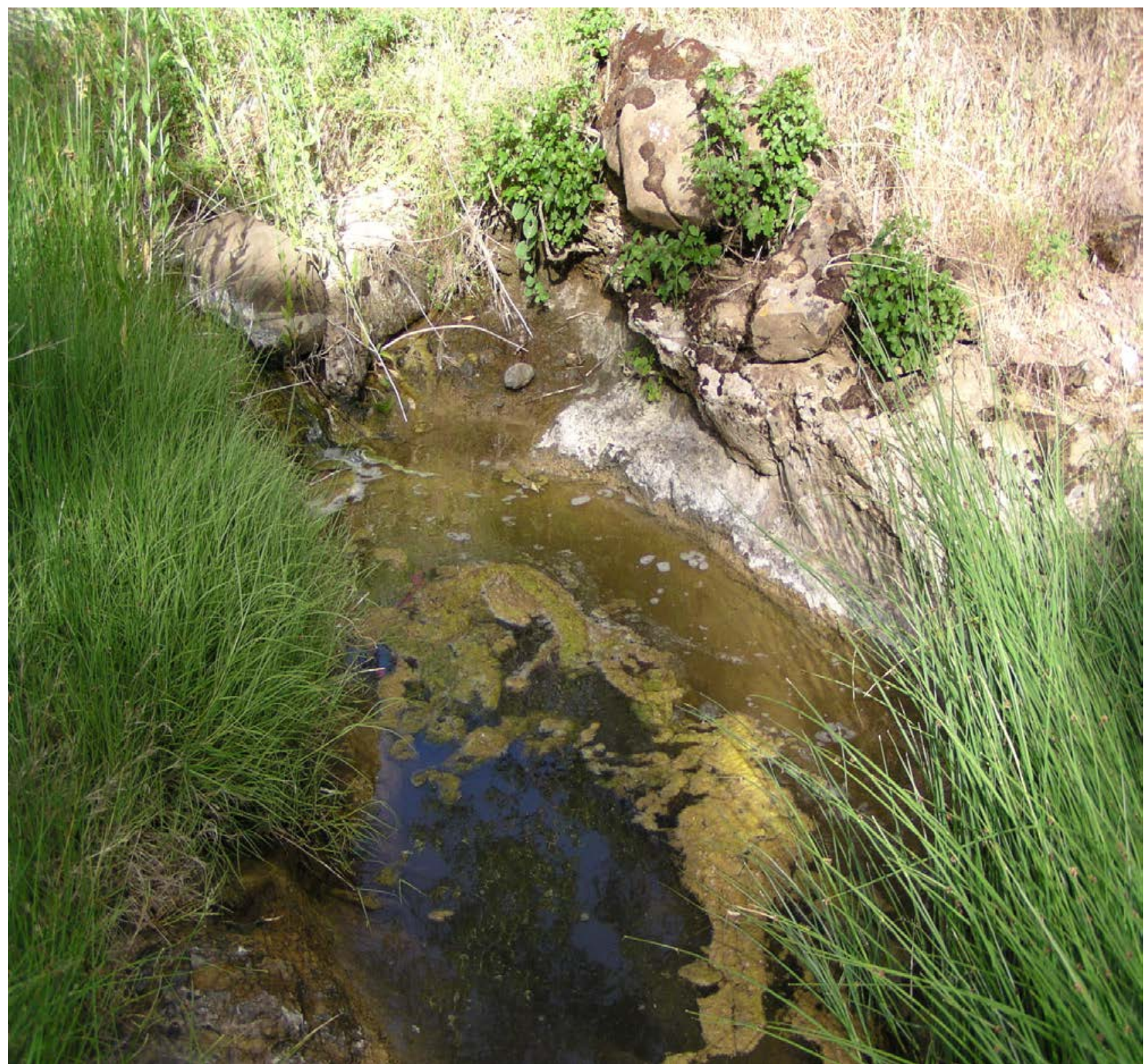

Figure 14. Sample site HG6 in the West Fork of Harley Gulch, Lake County, California. 

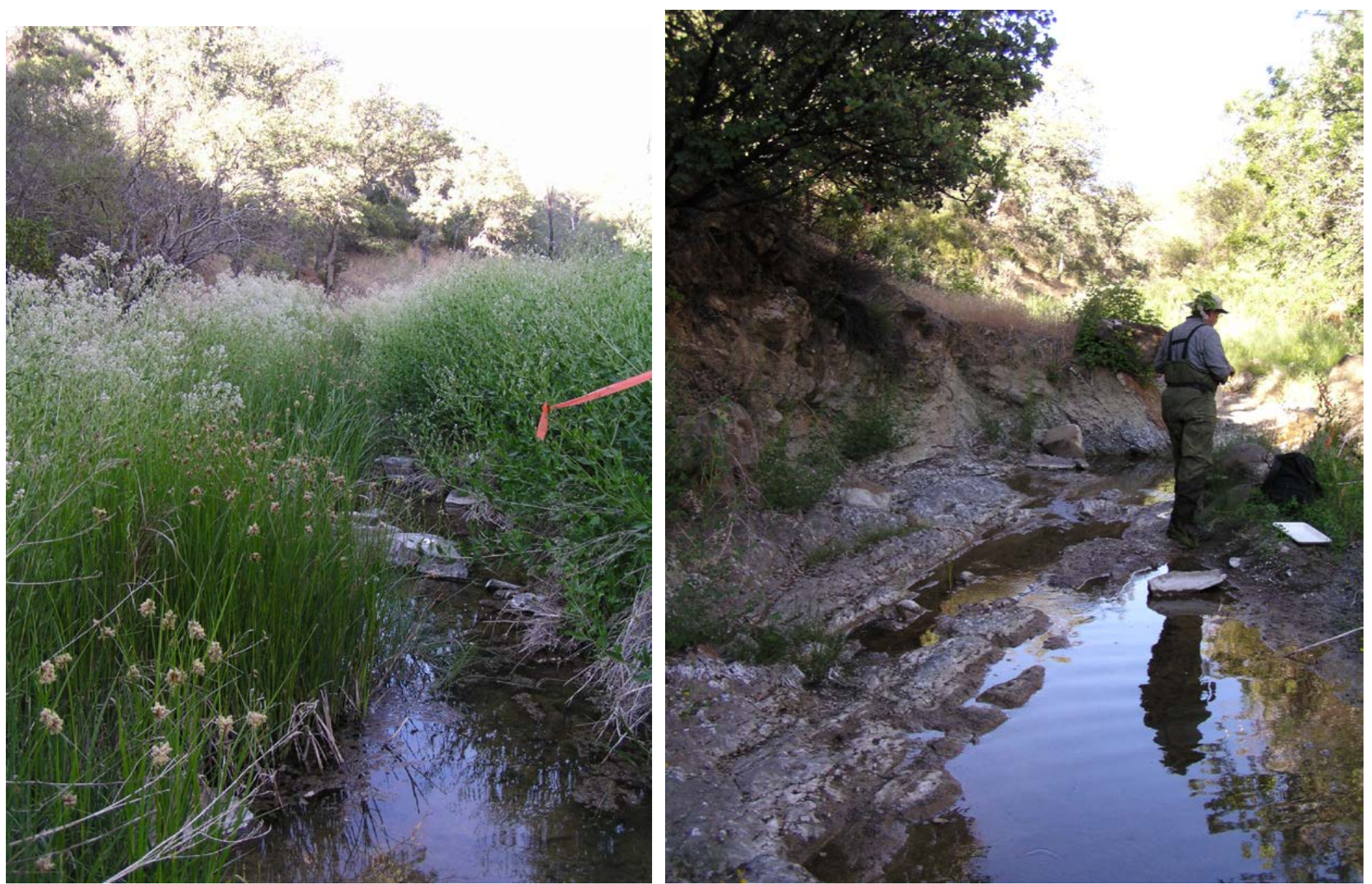

Figure 15. Sample sites HG7 (left) and sample site HG8 (right) in the West Fork of Harley Gulch, Lake County, California. 


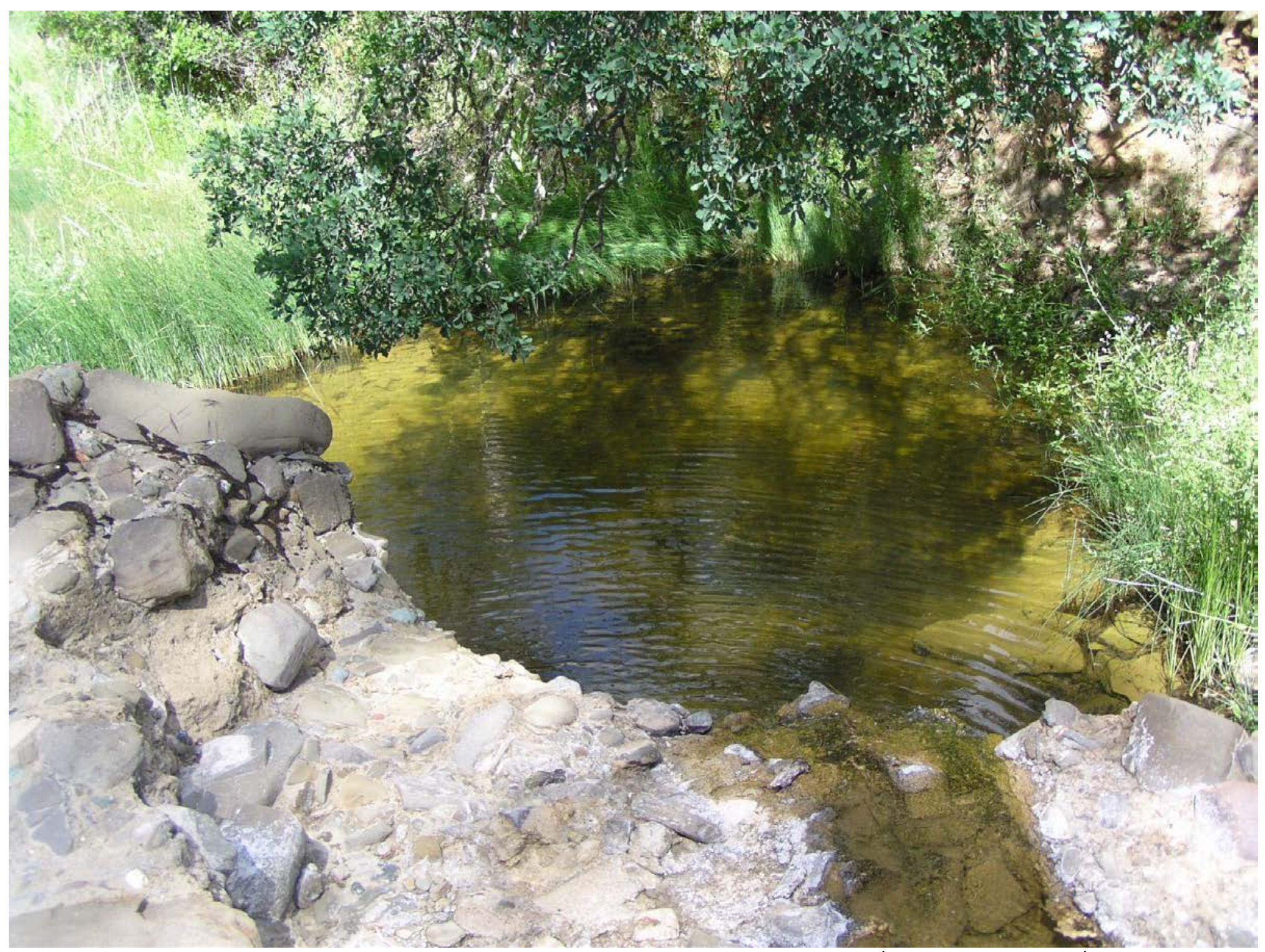

Figure 16. Sample site HG8a, Fish Pond, Harley Gulch, Lake County, California, sampled only in 2010 (June 10 and June 17). 

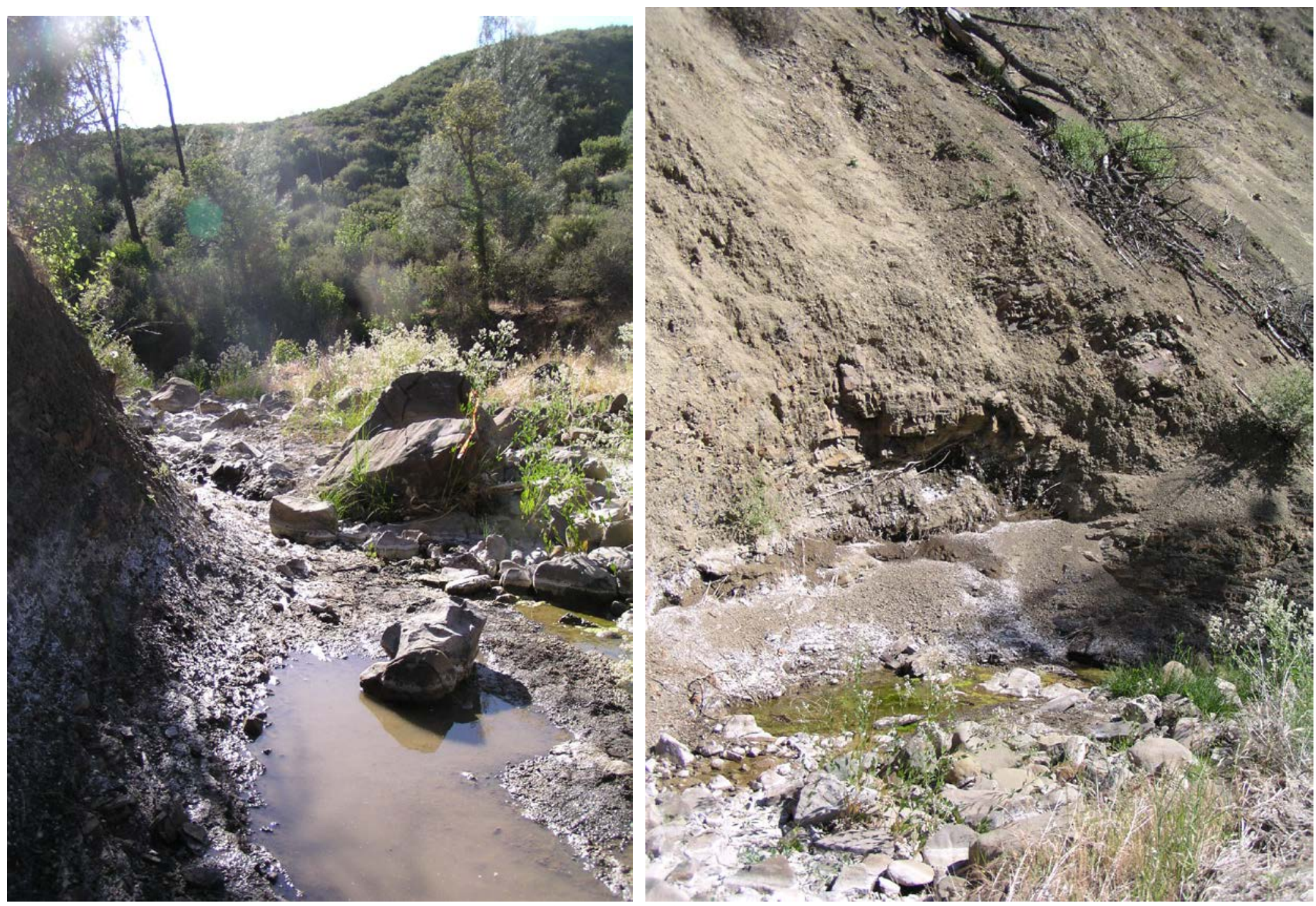

Figure 17. Sample sites HG9 and HG10 in the West Fork of Harley Gulch, Lake County, California. 

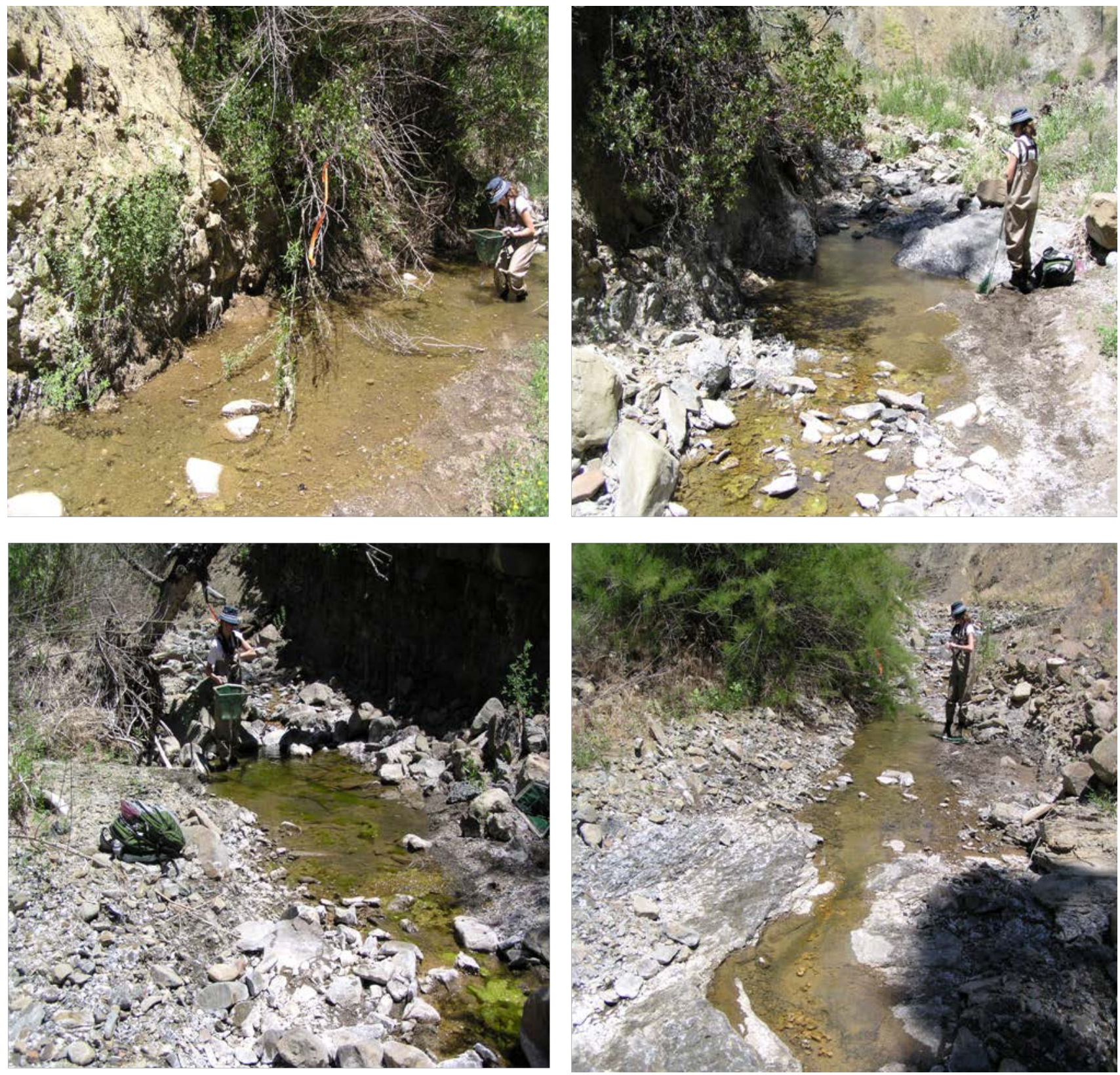

Figure 18. Sample sites HG11, HG12, HG13, and HG14 (clockwise from top left), Lake County, California sampled for biota only on June 4, 2008, and June 17, 2010. 


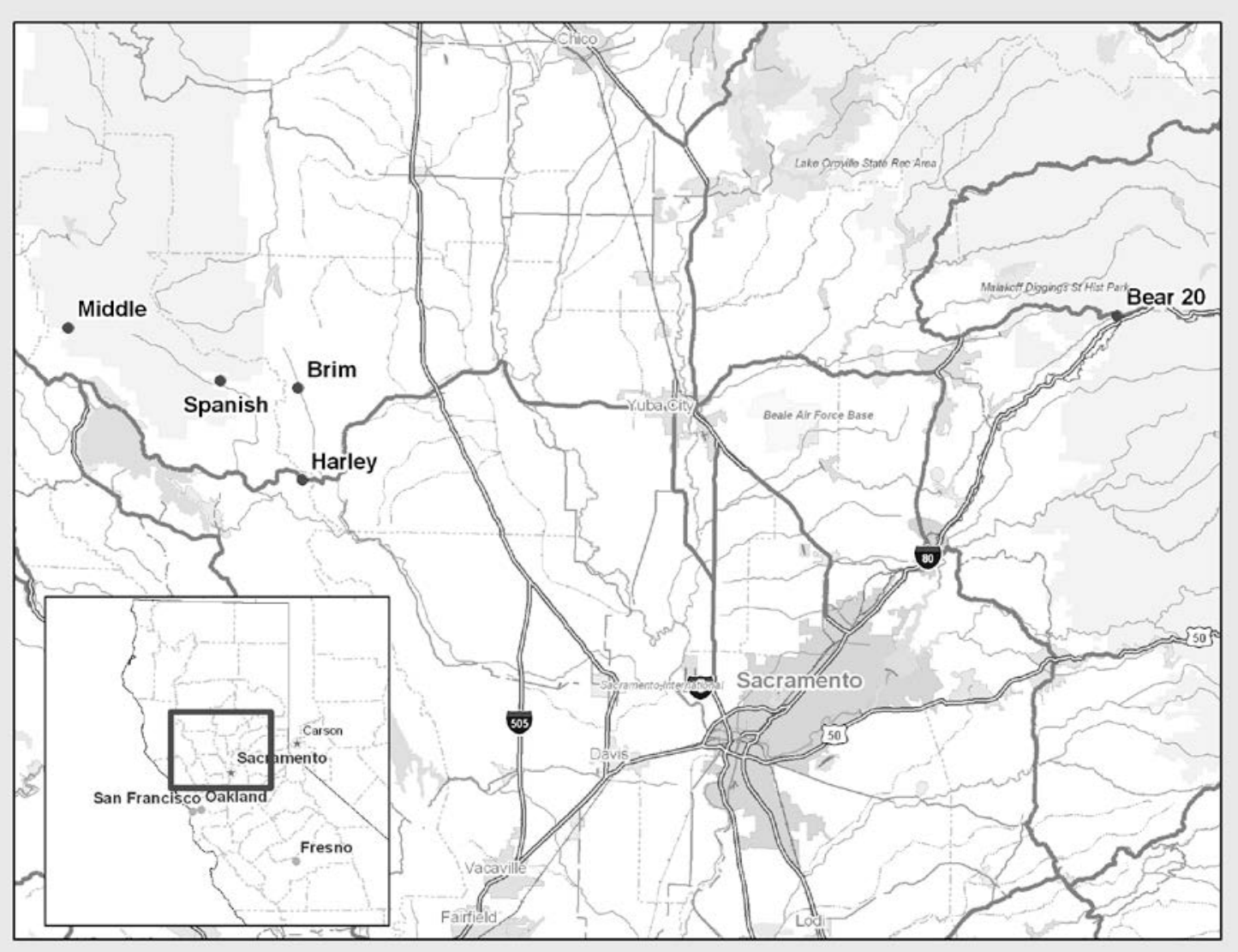

Figure 19. Locations of reference sites for studies at Harley Gulch, Lake County, California. [Foothill yellowlegged frog reference sites in 1997 were East Fork of Middle Creek (Middle), Spanish Creek (Spanish), and Bear Creek at Brim Road (Brim)] (Hothem and others, 2010). 


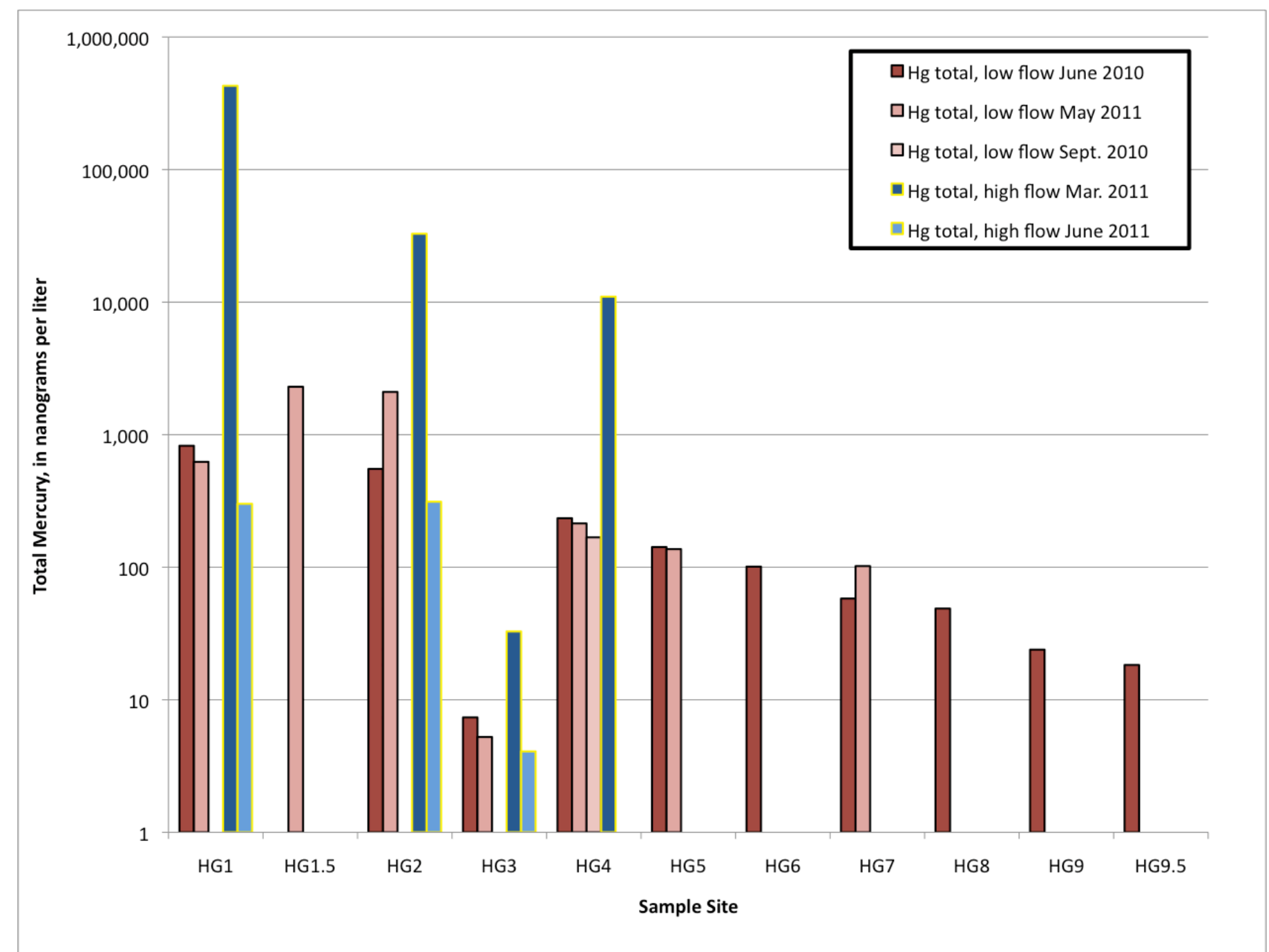

Figure 20. Logarithmic-scale plot showing concentrations of total mercury $\left(\mathrm{Hg}_{\mathrm{T}}\right)$ in water collected from sample sites in Harley Gulch, Lake County, California, moving downstream to the right on the x-axis. Low-flow sampling events are shown with red bars; high-flow sampling events are shown with blue bars. 


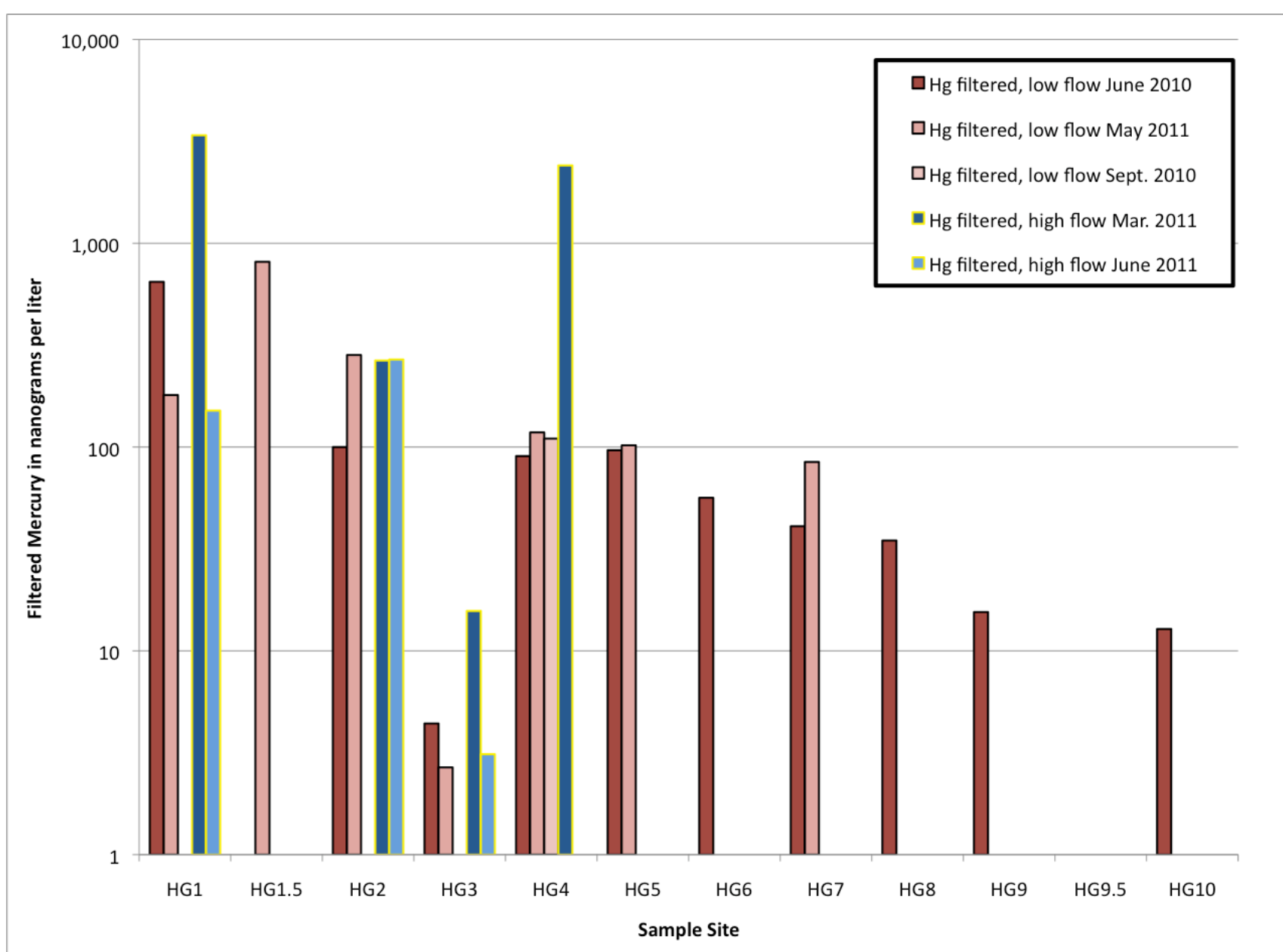

Figure 21. Logarithmic-scale plot showing concentrations of filtered mercury $\left(\mathrm{Hg}_{\mathrm{F}}\right)$ in water collected from sample sites in Harley Gulch, Lake County, California, moving downstream to the right on the x-axis. Low-flow sampling events are shown with red bars; high-flow sampling events are shown with blue bars. 


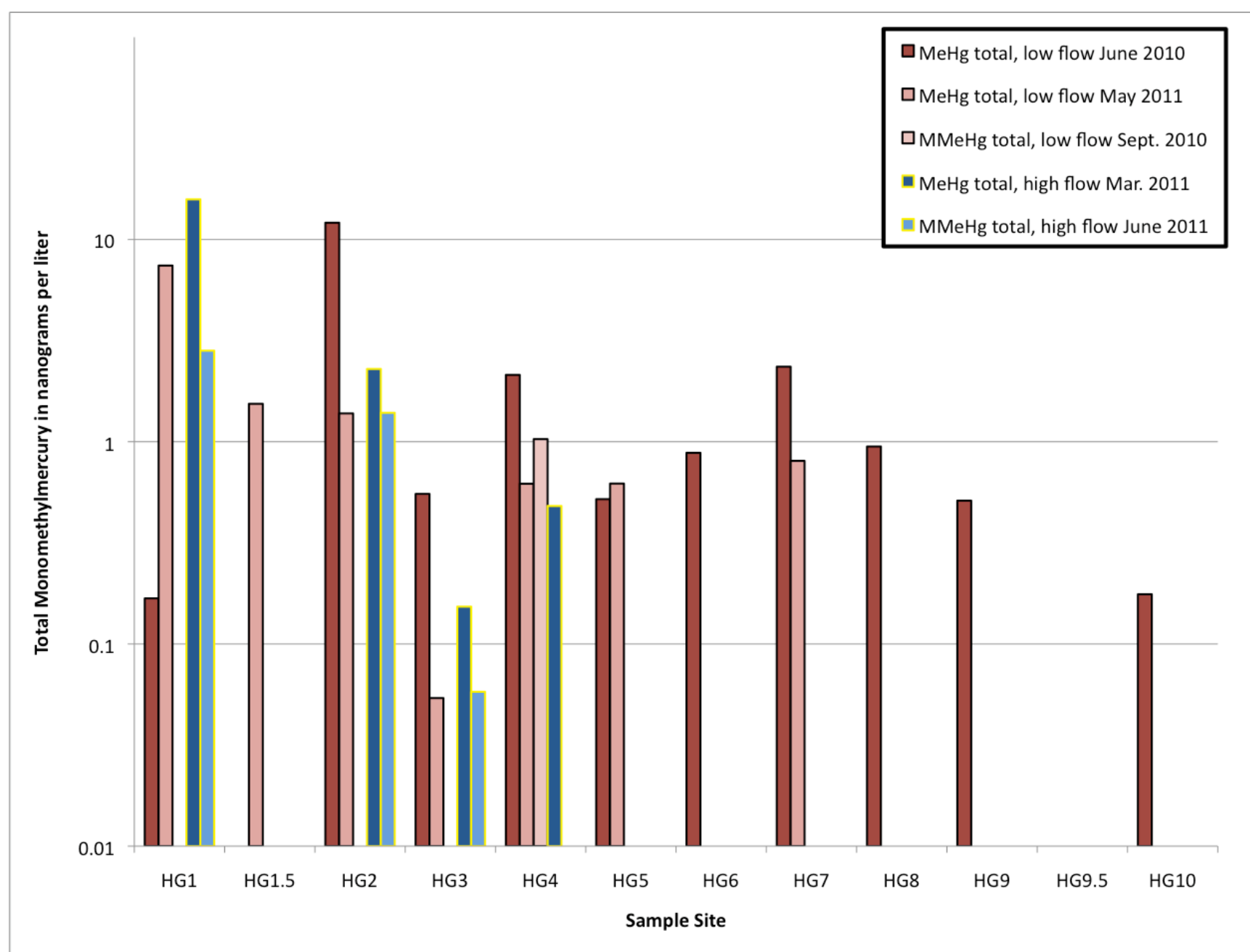

Figure 22. Logarithmic-scale plot showing concentrations of MMeHg in water collected from sample sites in Harley Gulch, Lake County, California, moving downstream to the right on the x-axis. Low-flow sampling events are shown with red bars; high-flow sampling events are shown with blue bars. 


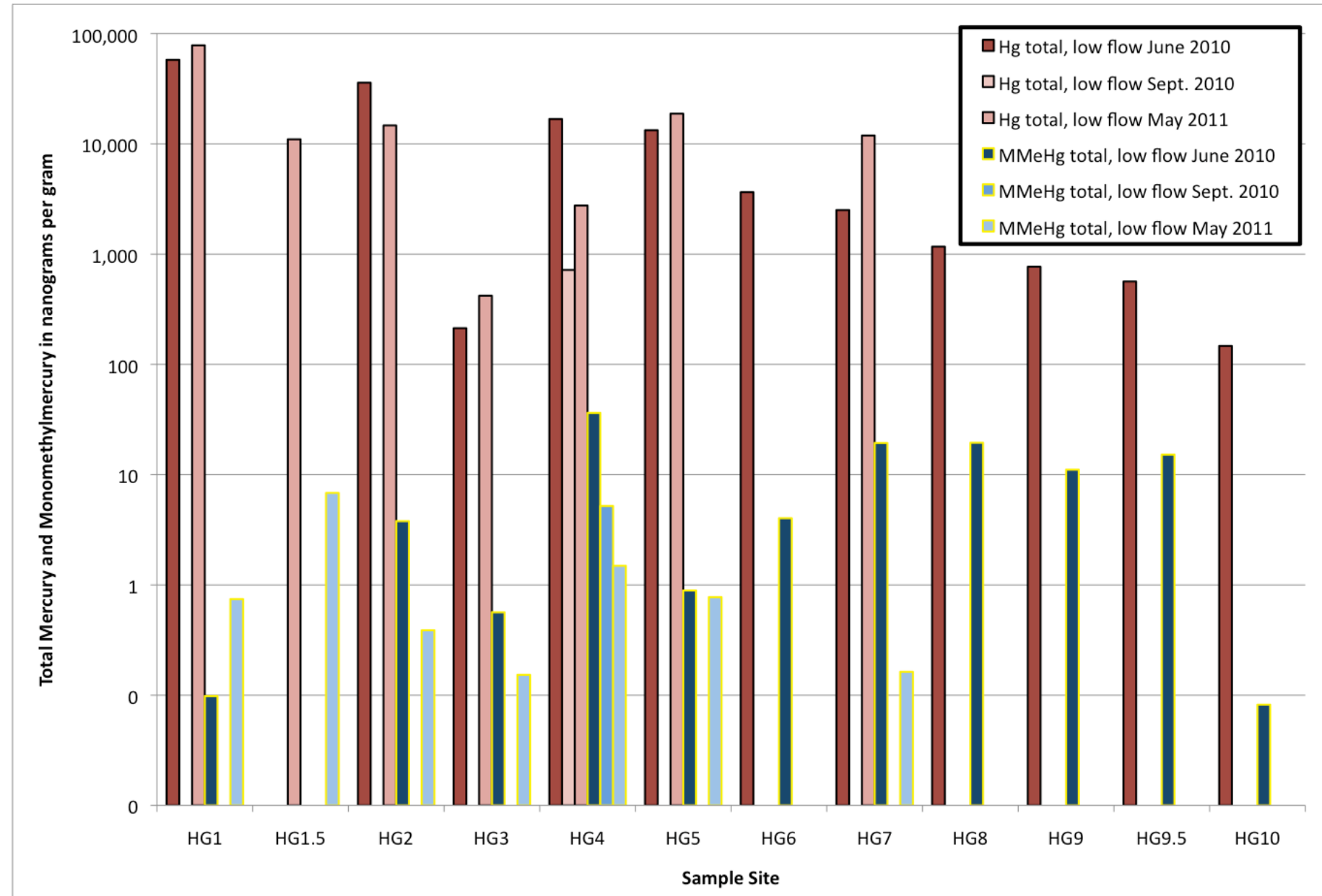

Figure 23. Logarithmic-scale plot showing concentrations of $\mathrm{Hg}$ and $\mathrm{MMeHg}$ in sediment collected from sample sites in Harley Gulch, Lake County, California, moving downstream to the right on the x-axis. Hg concentrations are shown by red bars, and MMeHg concentrations with blue bars. 


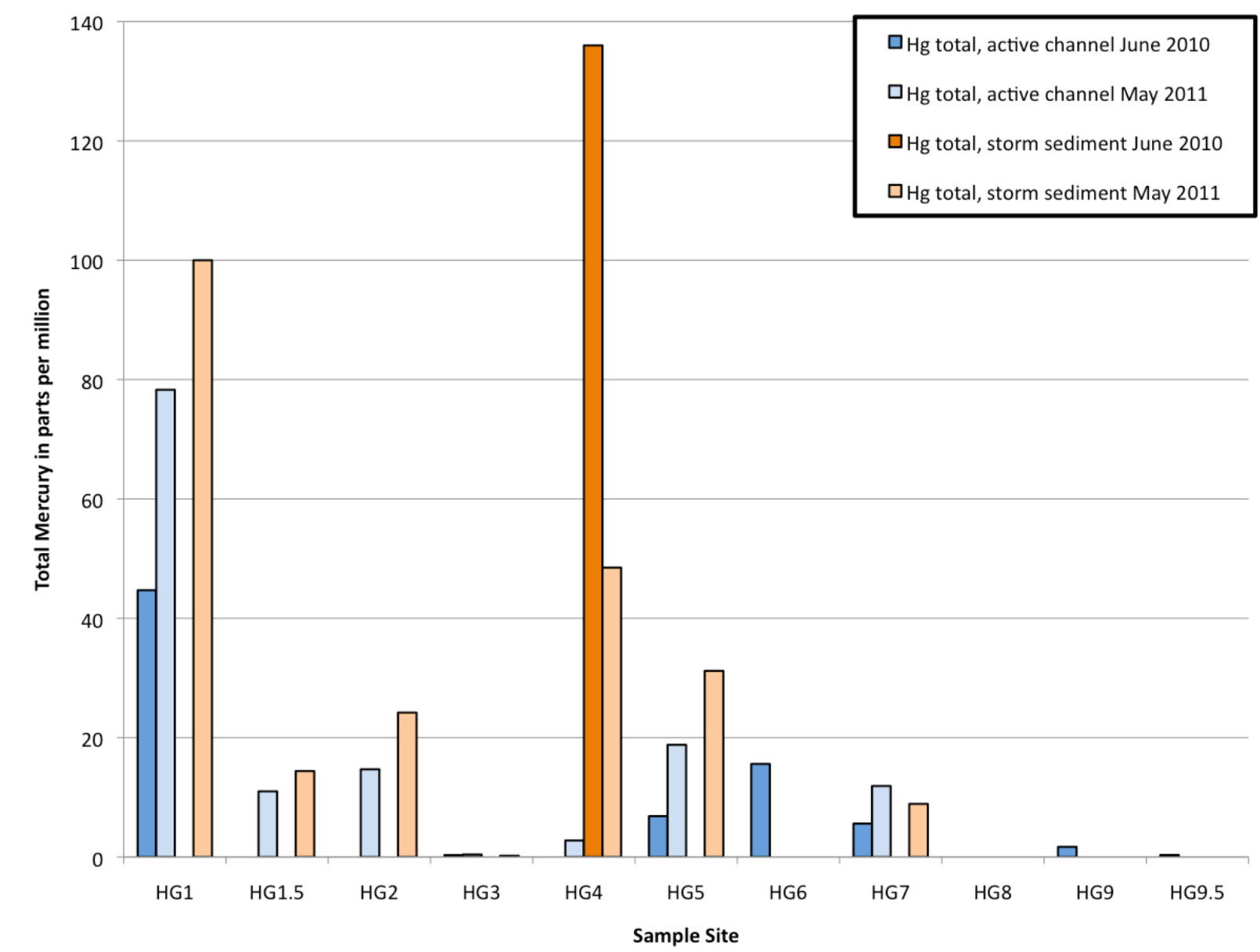

Figure 24. Plot showing concentration of $\mathrm{Hg}$ in sediments collected from Harley Gulch, Lake County, California. Samples collected from the active stream channel of Harley Gulch are shown with blue bars; samples collected from the banks of Harley Gulch where storm sediment is deposited are shown with orange bars. 


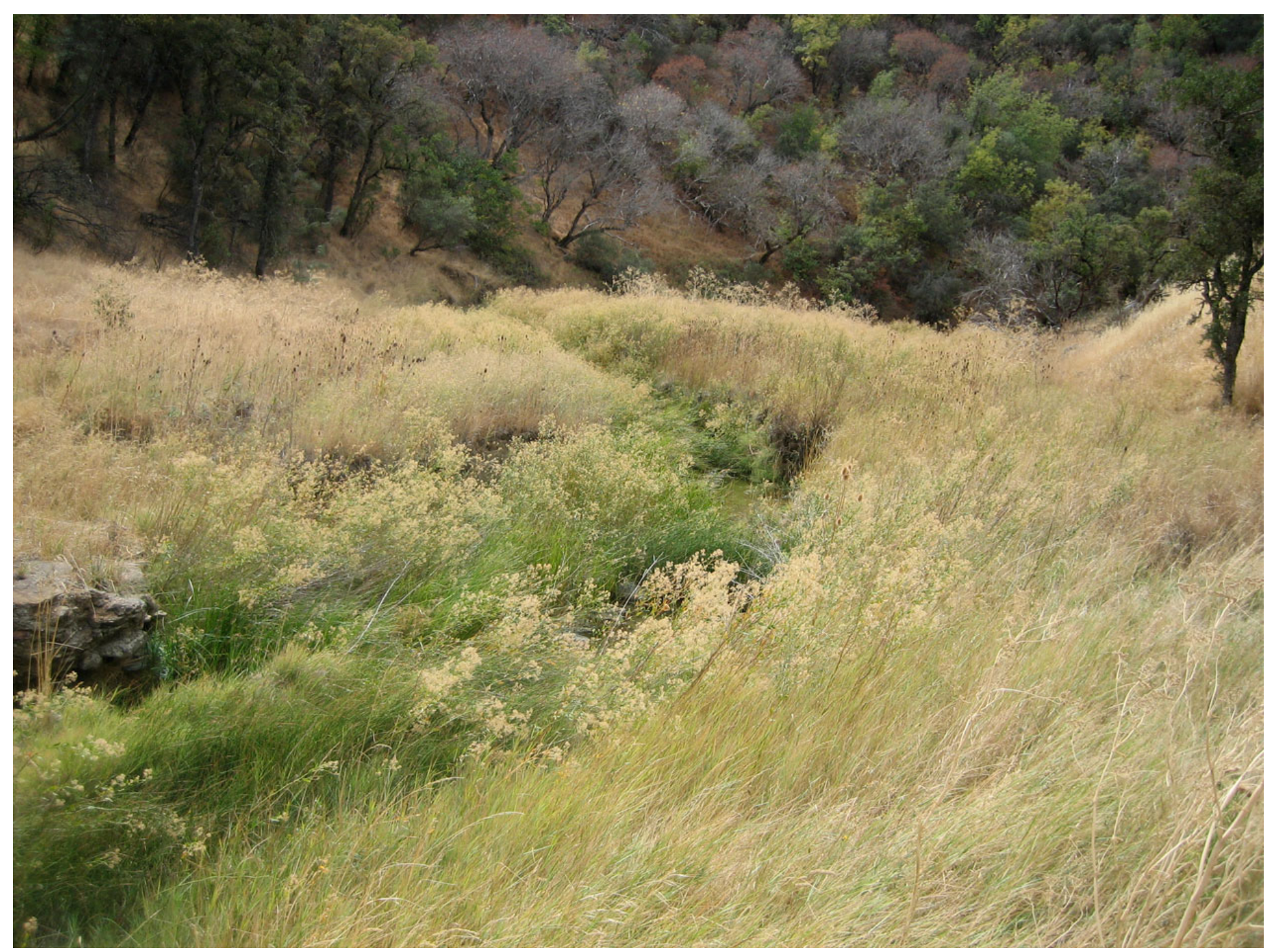

Figure 25. Harley Gulch, Lake County, California, downstream from sample site HG4 has abundant riparian vegetation because of input of connate groundwater in the segment of the creek between sample sites HG4 and HG7. 


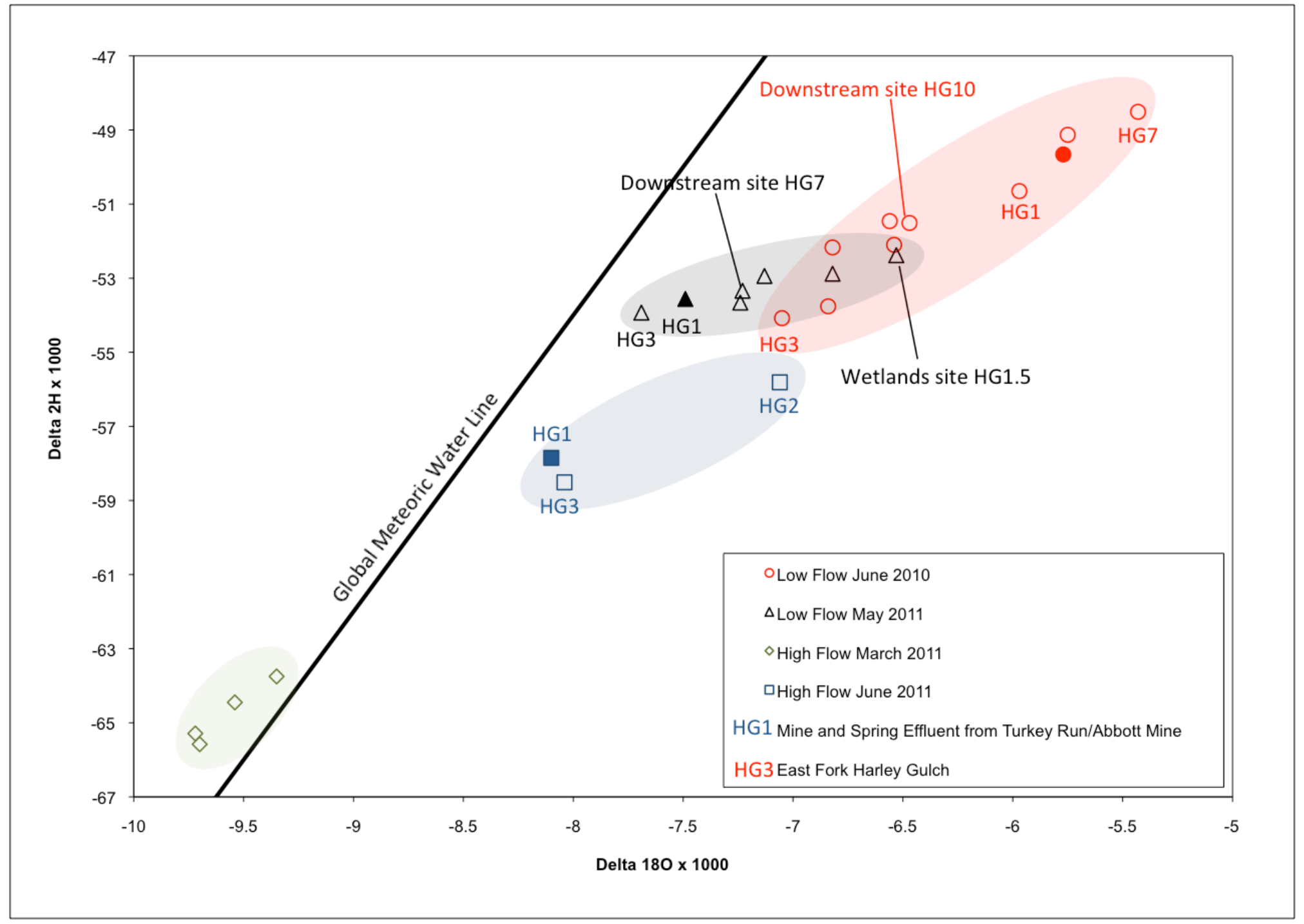

Figure 26. Plot of isotopic composition of waters in Harley Gulch, Lake County, California, which shows that the waters do not fall along the meteoric water line and are, thus, a mixture of connate water, thermal water, and meteoric water. 


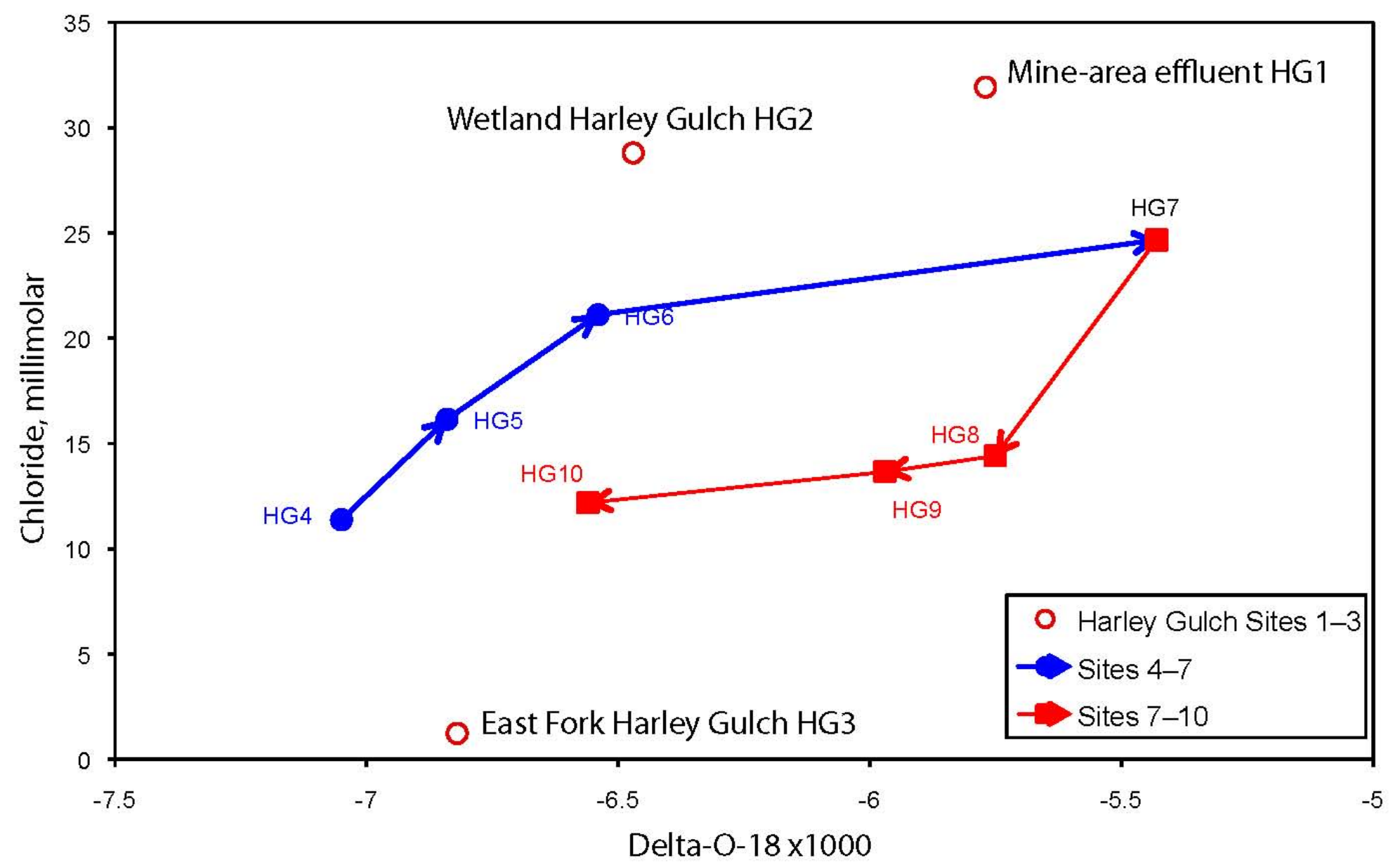

Figure 27. Plot of chloride $(\mathrm{Cl})$ and $\delta^{18} \mathrm{O}$ of water in Harley Gulch, Lake County, California. The creek water becomes systematically heavier with higher $\mathrm{Cl}$ concentration downstream from site $\mathrm{HG}$, reaching a maximum in $\delta^{18} \mathrm{O}$ and $\mathrm{Cl}$ concentration at site $\mathrm{HG} 7$. The creek water then decreases in $\delta^{18} \mathrm{O}$ and $\mathrm{Cl}$ concentration owing to mixing with isotopically-light meteoric water. 


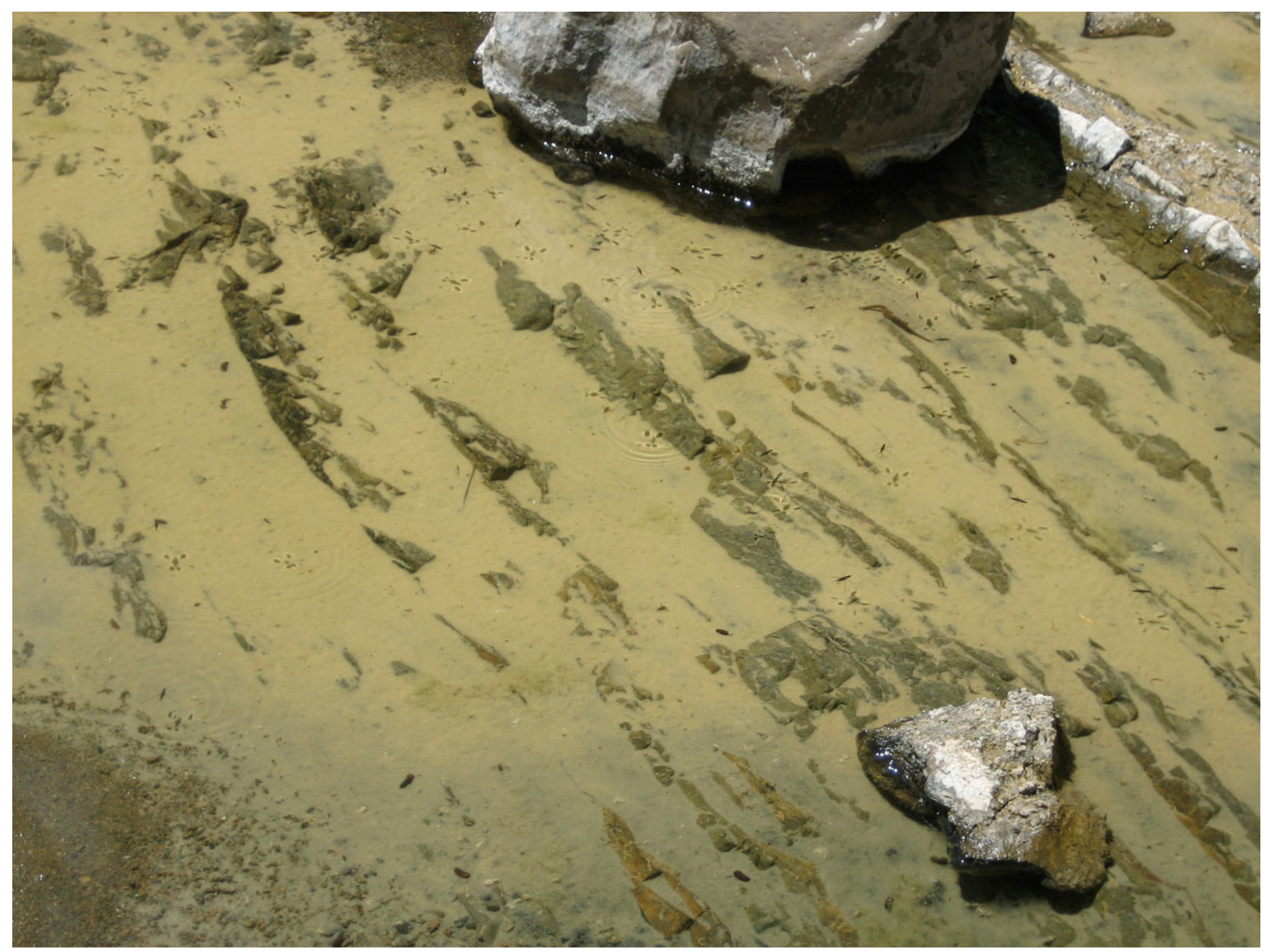

Figure 28. Tan biogenic sediment at sample site HG8 forms in the upper part of Harley Gulch, Lake County, California, in the area between sample sites $\mathrm{HG} 2 \mathrm{~A}$ and $\mathrm{HG}$, where connate groundwater high in $\mathrm{SO}_{4}-\mathrm{Cl}_{-} \mathrm{CO}_{3}$ enters the creek and dominates the water chemistry. 


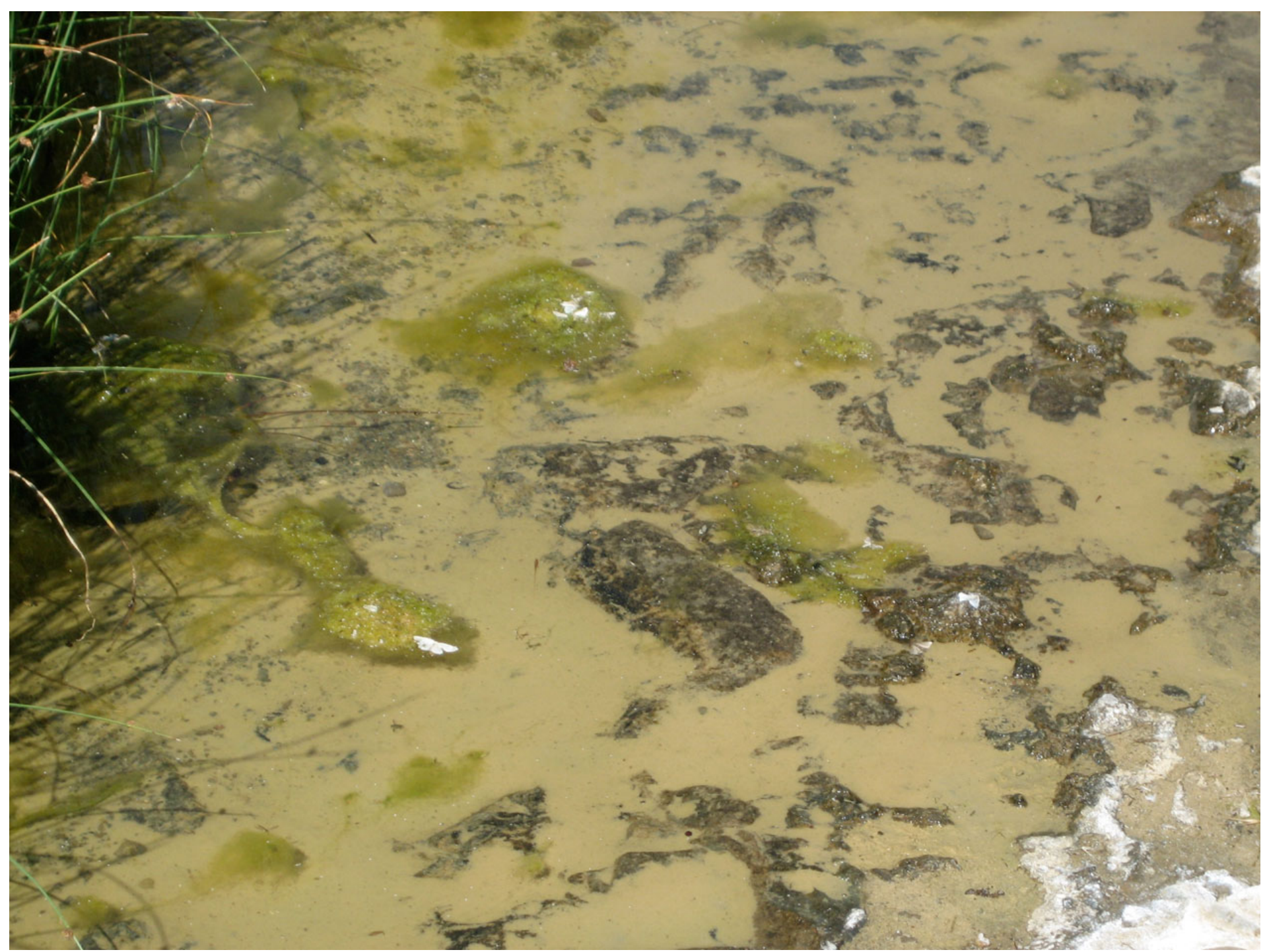

Figure 29. Tan biogenic sediment accumulating on creek bed at sample site HG7, Harley Gulch, Lake County, California, consists of living and recently expired diatoms with high concentrations of $\mathrm{Hg}[5.6 \mu \mathrm{g} / \mathrm{g}(\mathrm{ppm})]$, and $\mathrm{MMeHg}(0.5 \mathrm{ng} / \mathrm{g})$. 


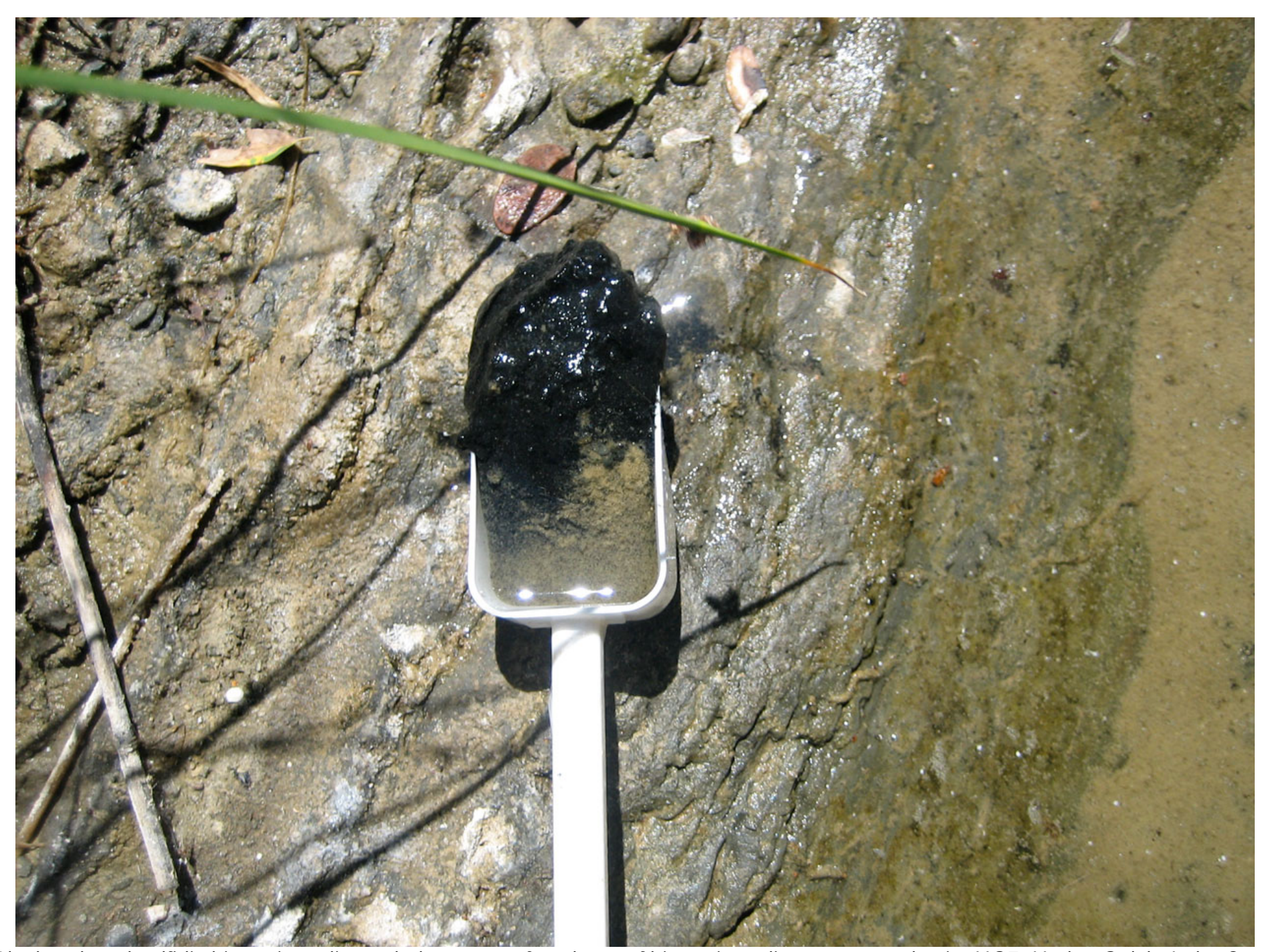

Figure 30. Black reduced sulfidic biogenic sediment below tan surface layer of biogenic sediment at sample site HG7, Harley Gulch, Lake County, California. The sediment consists of expired diatoms and FeS that gives the sediment a black color. 


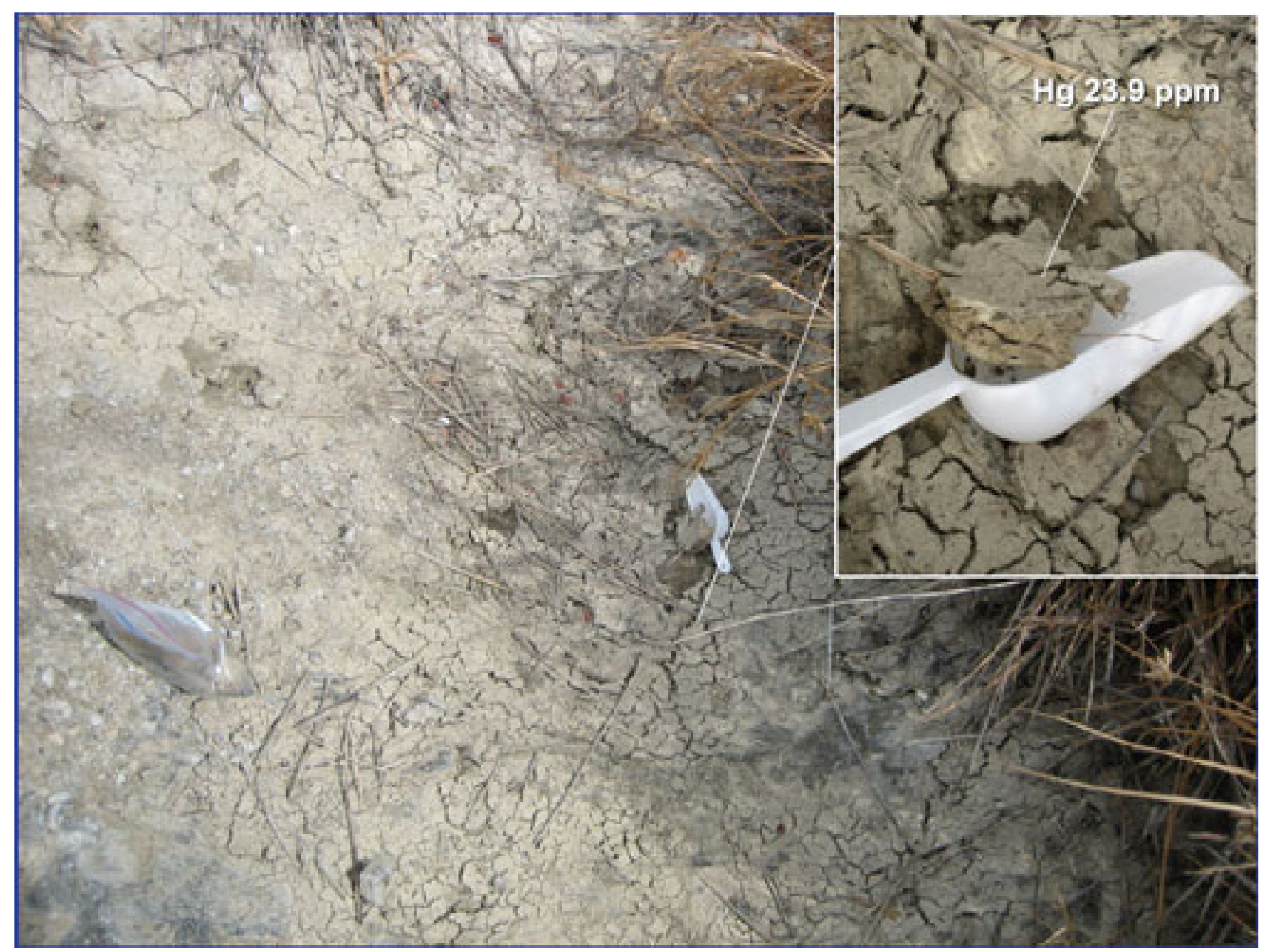

Figure 31. Biogenic sediment accumulates to a thickness of several 10s of $\mathrm{cm}$ in Harley Gulch, Lake County, California. Above site HG4, during the dry season, biogenic sediment with high $\mathrm{Hg}$ concentration [23.9 $\mathrm{g} / \mathrm{g}(\mathrm{ppm})]$ locally becomes dry and has the consistency of diatomite. 


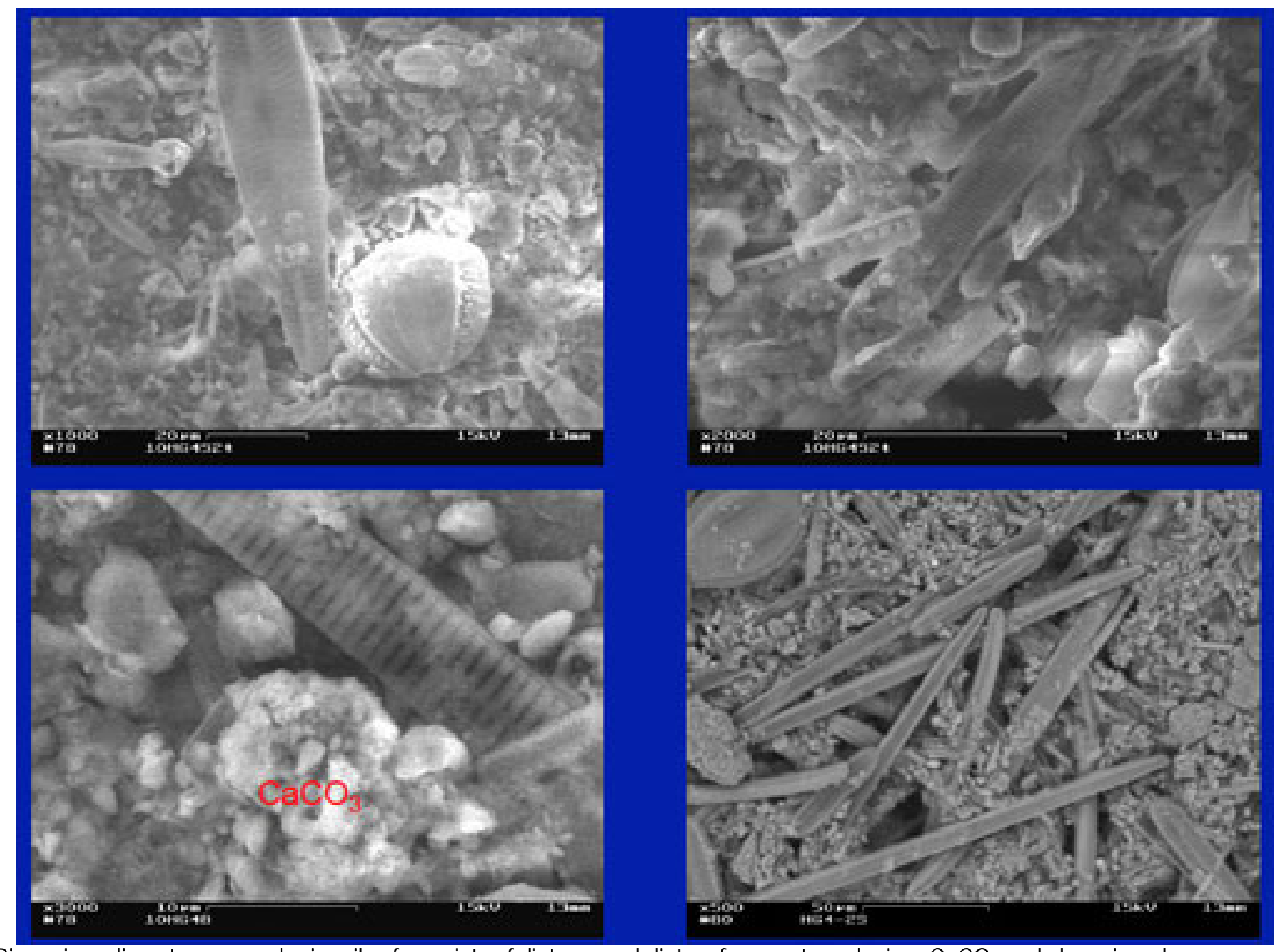

Figure 32. Biogenic sediment composed primarily of a variety of diatoms and diatom fragments and minor $\mathrm{CaCO}_{3}$ and clay minerals. 


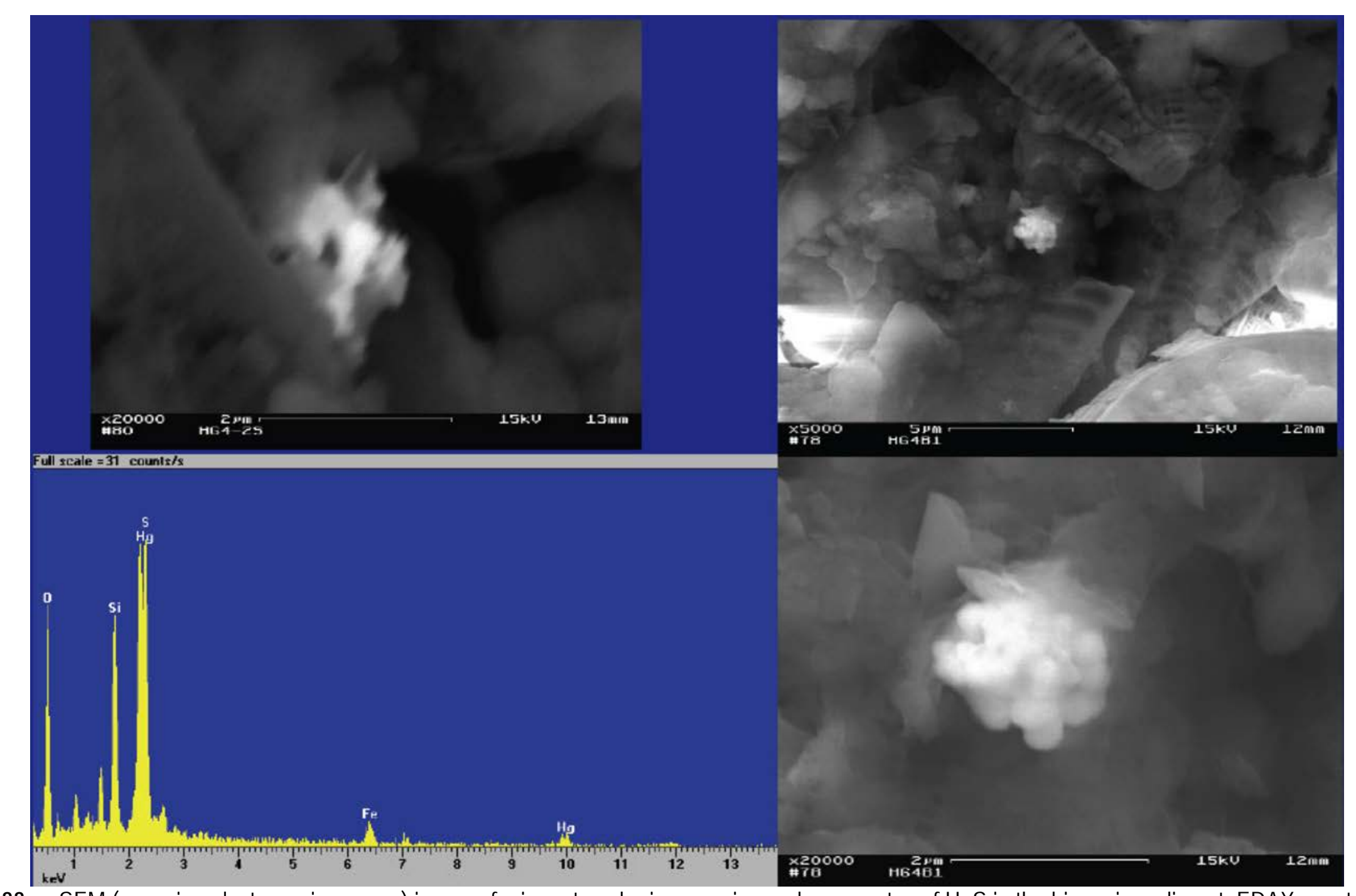

Figure 33. SEM (scanning electron microscopy) image of micron to submicron grains and aggregates of $\mathrm{HgS}$ in the biogenic sediment. EDAX spectrum confirms the presence of only $\mathrm{Hg}$ and sulfur (S) in the bright particles in the SEM image. 


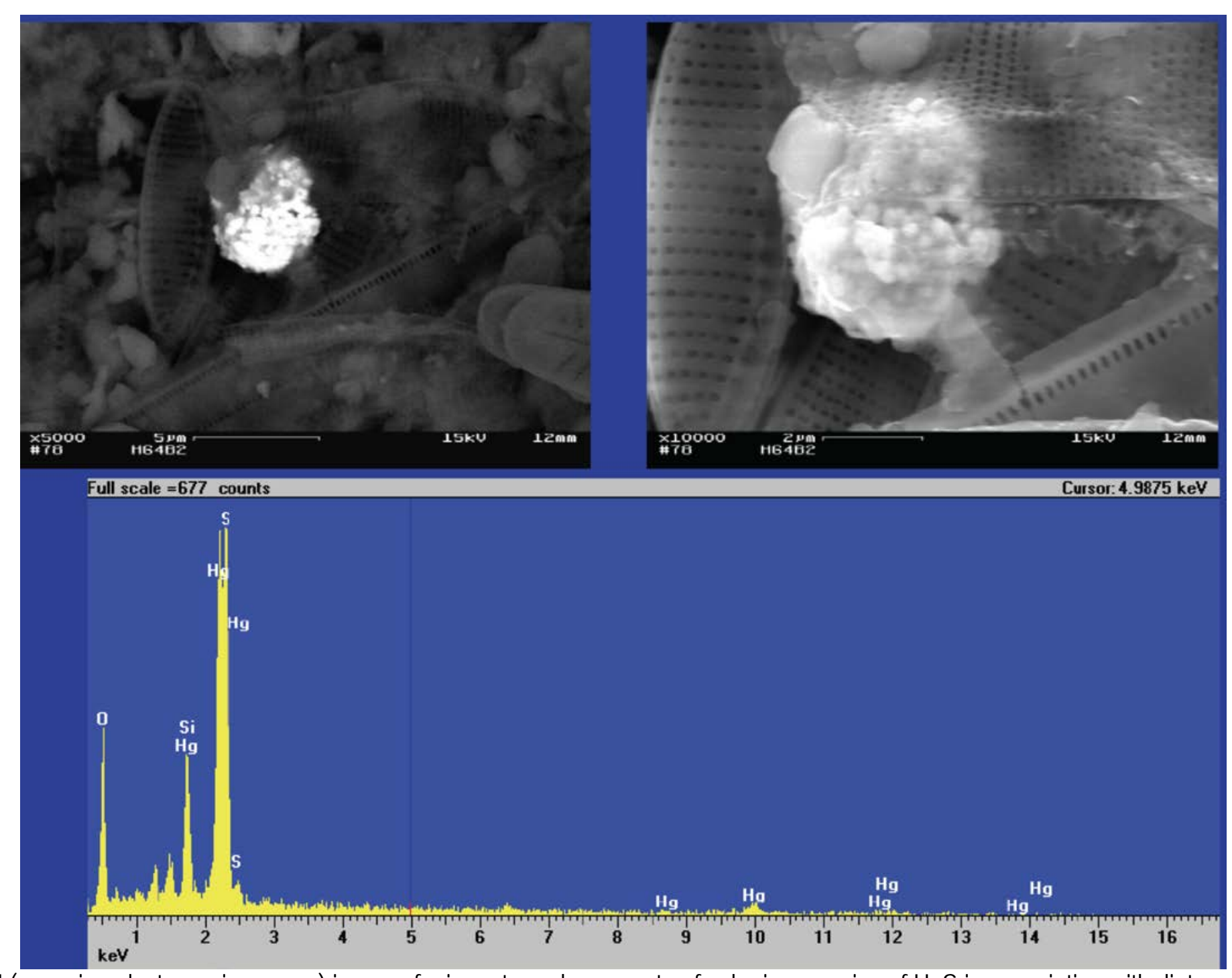

Figure 34. SEM (scanning electron microscopy) image of micron to and aggregate of submicron grains of $\mathrm{HgS}$ in association with diatoms in the biogenic sediment. EDAX spectrum confirms the presence of only $\mathrm{Hg}$ and $\mathrm{S}$ in the high reflectivity aggregate of $\mathrm{HgS}$ in the SEM image. 


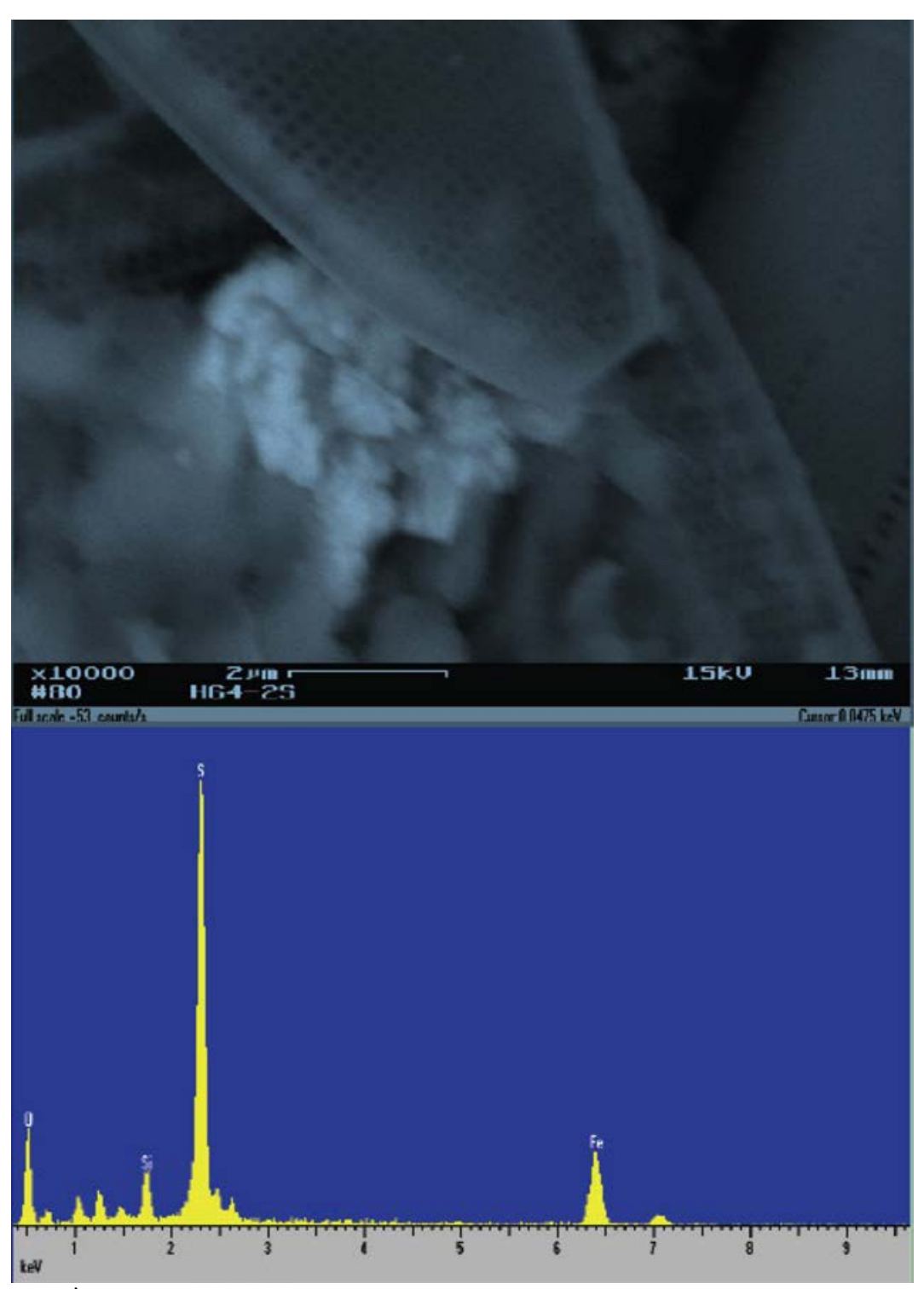

Figure 35. SEM (scanning electron microscopy) image of aggregate of submicron grains of FeS in association with diatoms in the biogenic sediment. EDAX spectrum confirms the presence of only Fe and $S$ in the high reflectivity aggregate of FeS in the SEM image. 


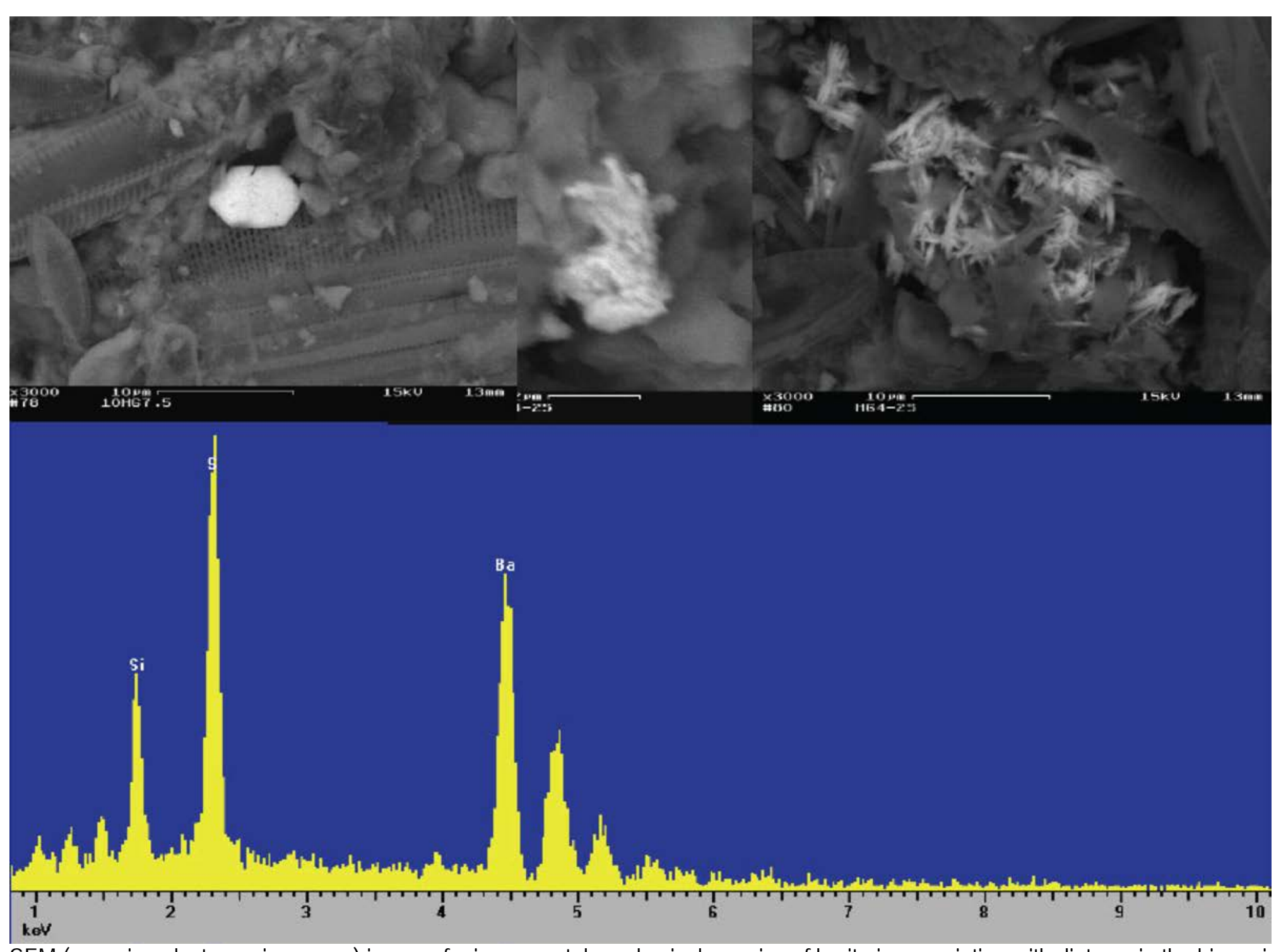

Figure 36. SEM (scanning electron microscopy) image of micron crystals and acicular grains of barite in association with diatoms in the biogenic sediment. EDAX spectrum confirms the presence of only $\mathrm{Ba}$ and $\mathrm{S}$ in the high reflectivity grains of barite. 

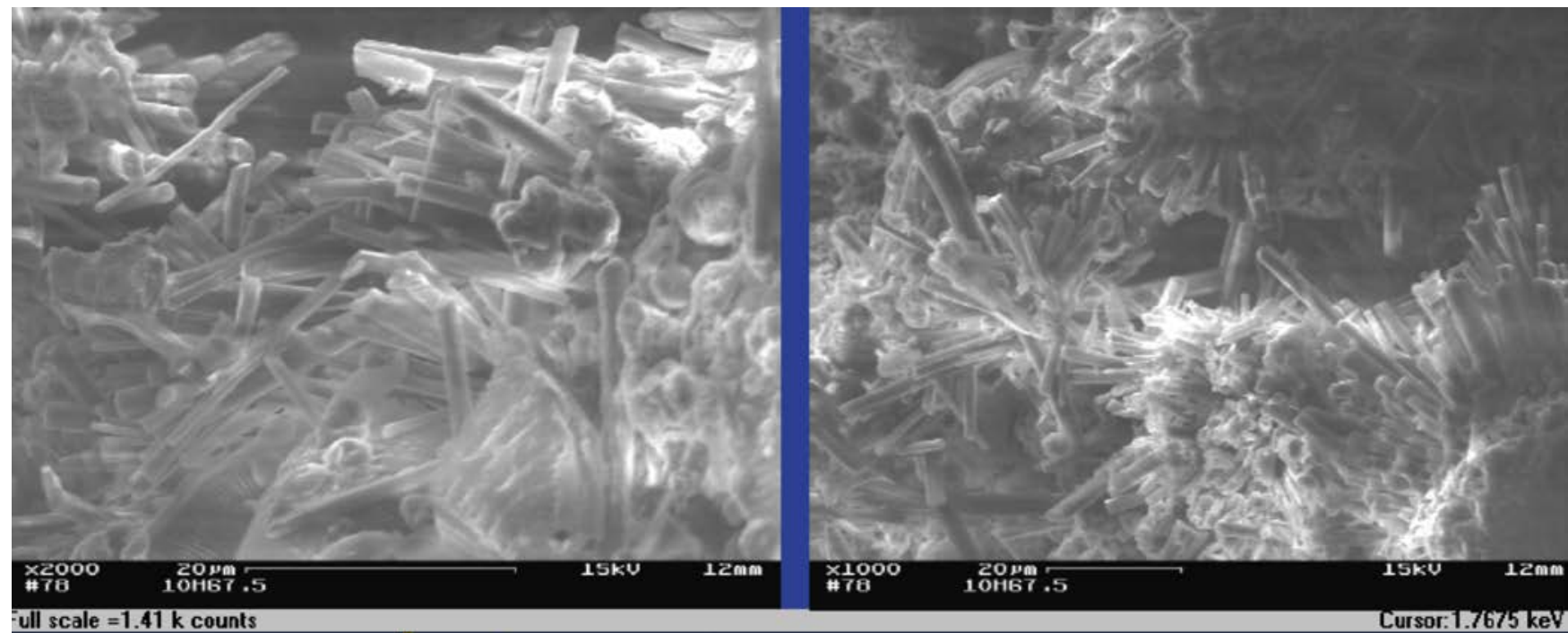

ull scale $=1.41 \mathrm{k}$ counts
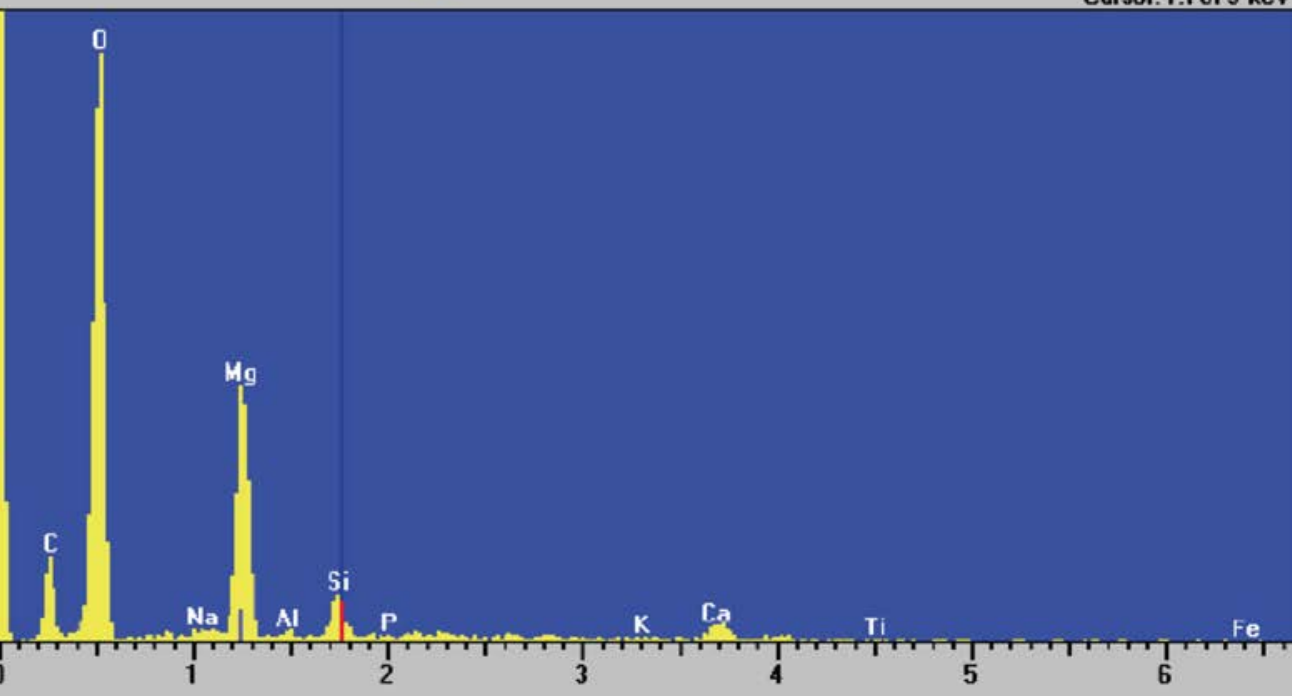

Figure 37. SEM (scanning electron microscopy) image of epsomite crystals in biogenic sediment. EDAX spectrum confirms the presence of Mg and S in the crystals. 


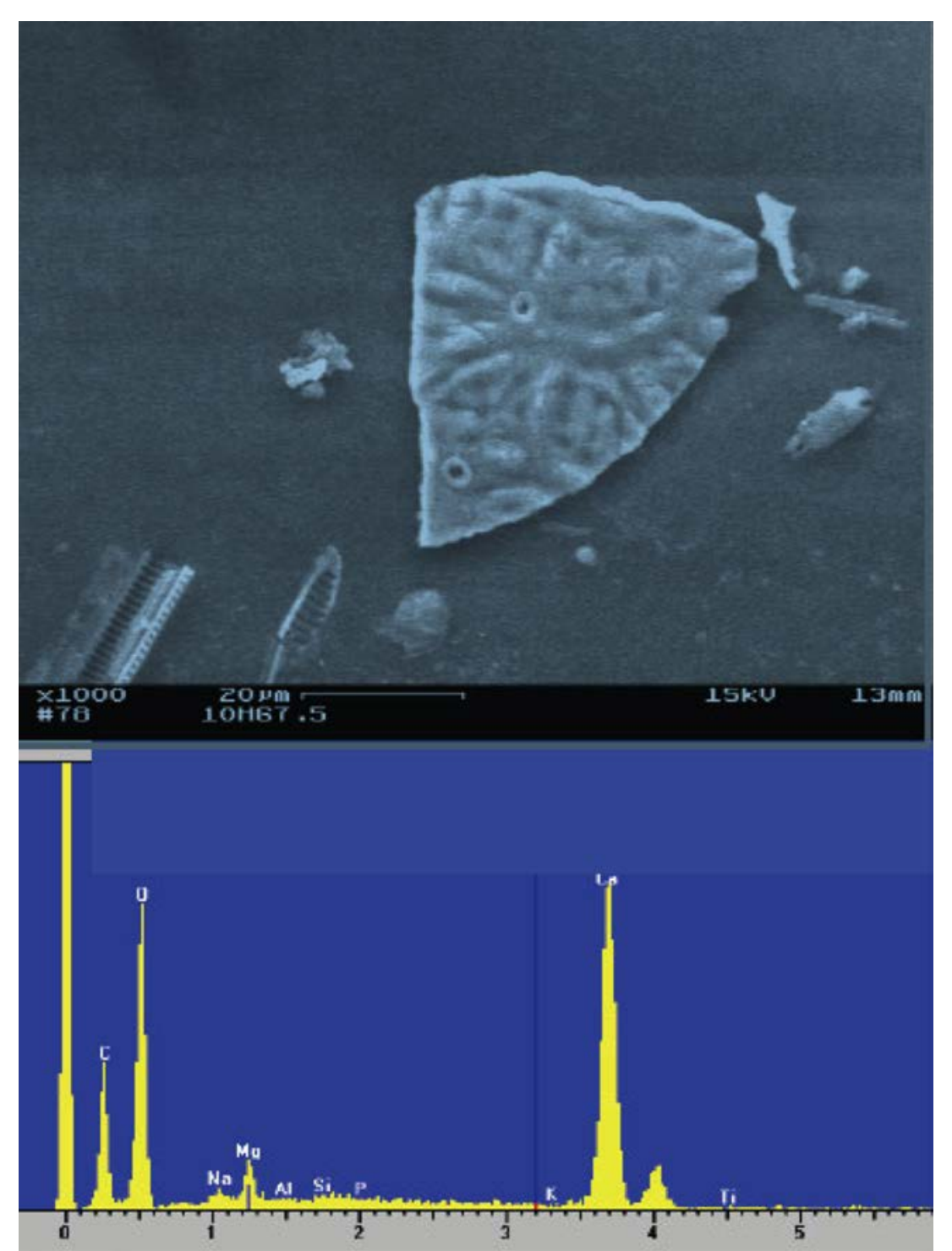

Figure 38. SEM (scanning electron microscopy) image of biogenic calcite fragment in biogenic sediment. EDAX spectrum confirms the presence of Ca and $\mathrm{C}$ in the crystals. 


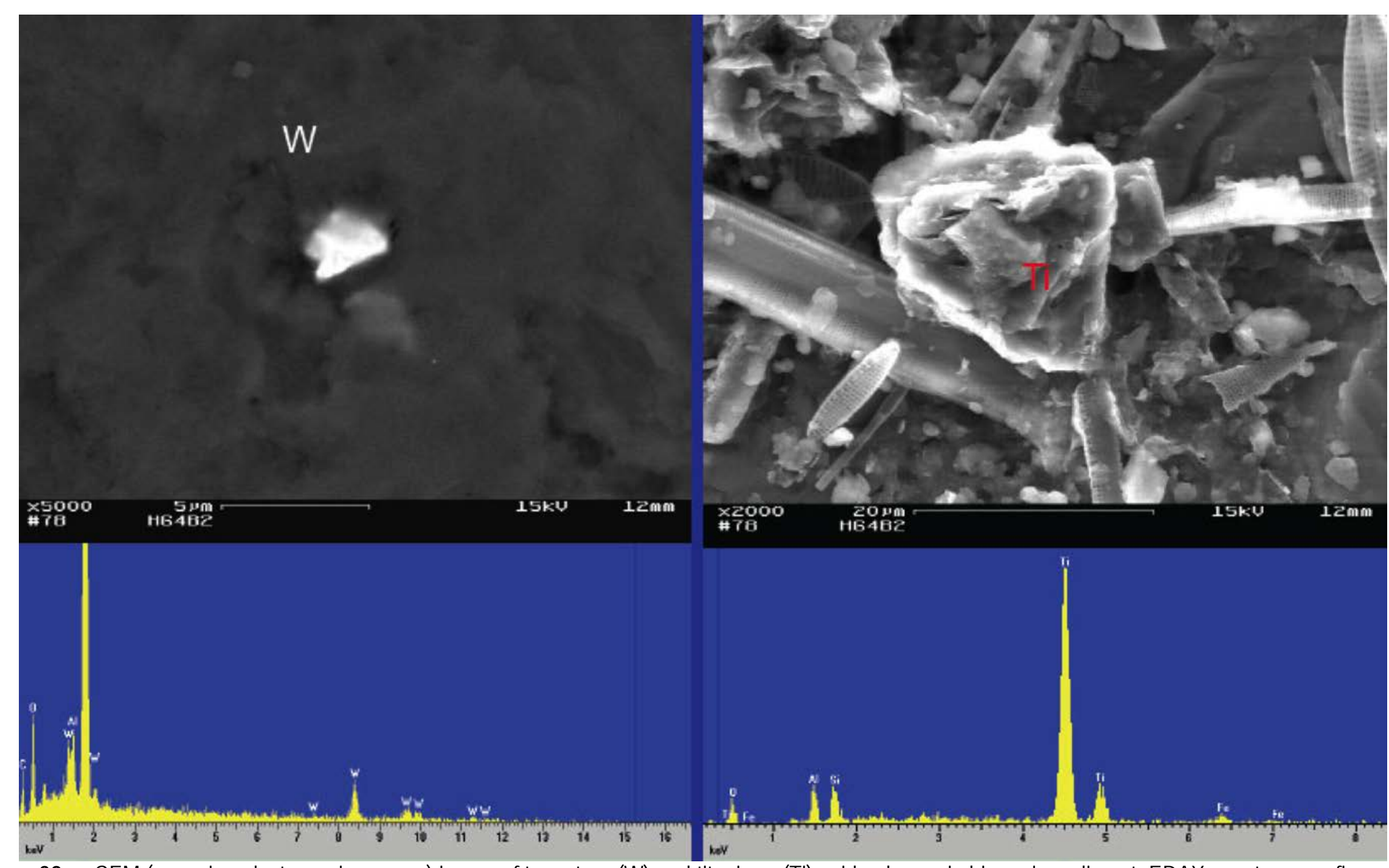

Figure 39. SEM (scanning electron microscopy) image of tungsten- (W) and titanium- (Ti) oxide phases in biogenic sediment. EDAX spectrum confirms the composition of the phases. 


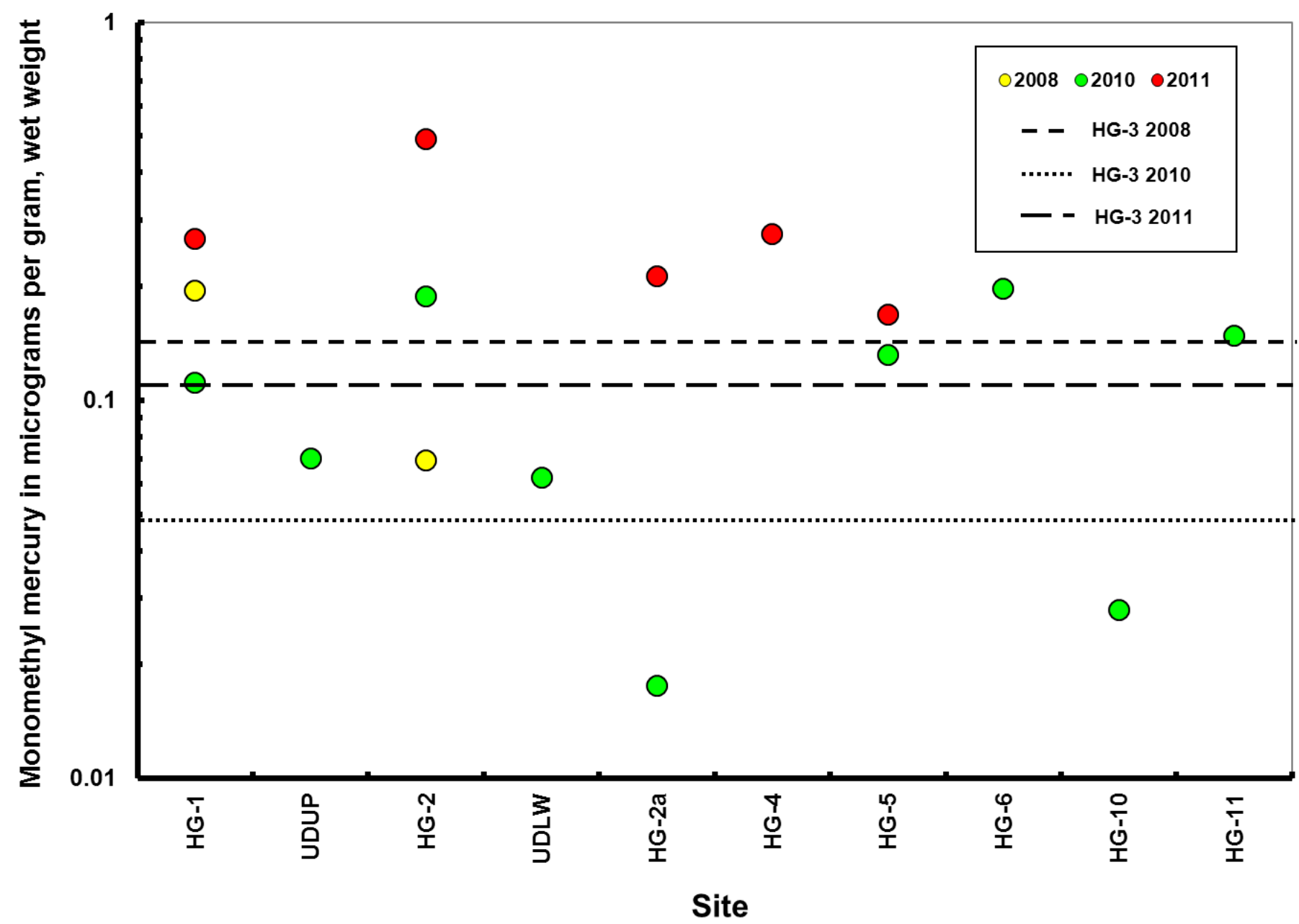

Figure 40. Monomethylmercury (MMeHg, $\mu \mathrm{g} / \mathrm{g}$, wet wt) in individual composite samples of predaceous diving beetles (Order Coleoptera, Family Dytiscidae) collected from Harley Gulch, Lake County, California, in2008, 2010, and 2011. 


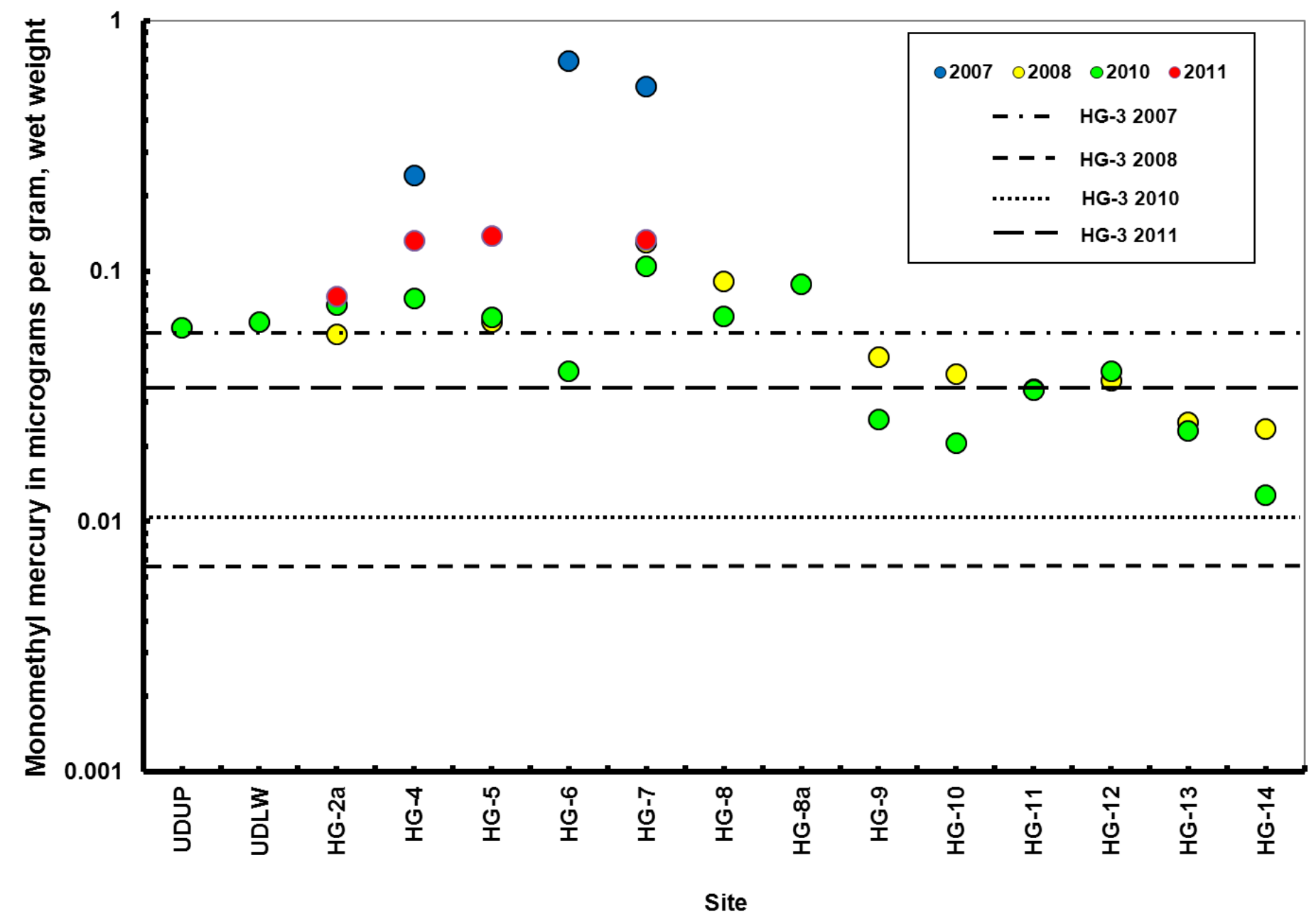

Figure 41. Monomethyl mercury (MMeHg, $\mu \mathrm{g} / \mathrm{g}$, wet wt) in composite samples of water striders (Order Hemiptera, Family Gerridae) collected from Harley Gulch, Lake County, California in 2007, 2008, 2010, and 2011. 


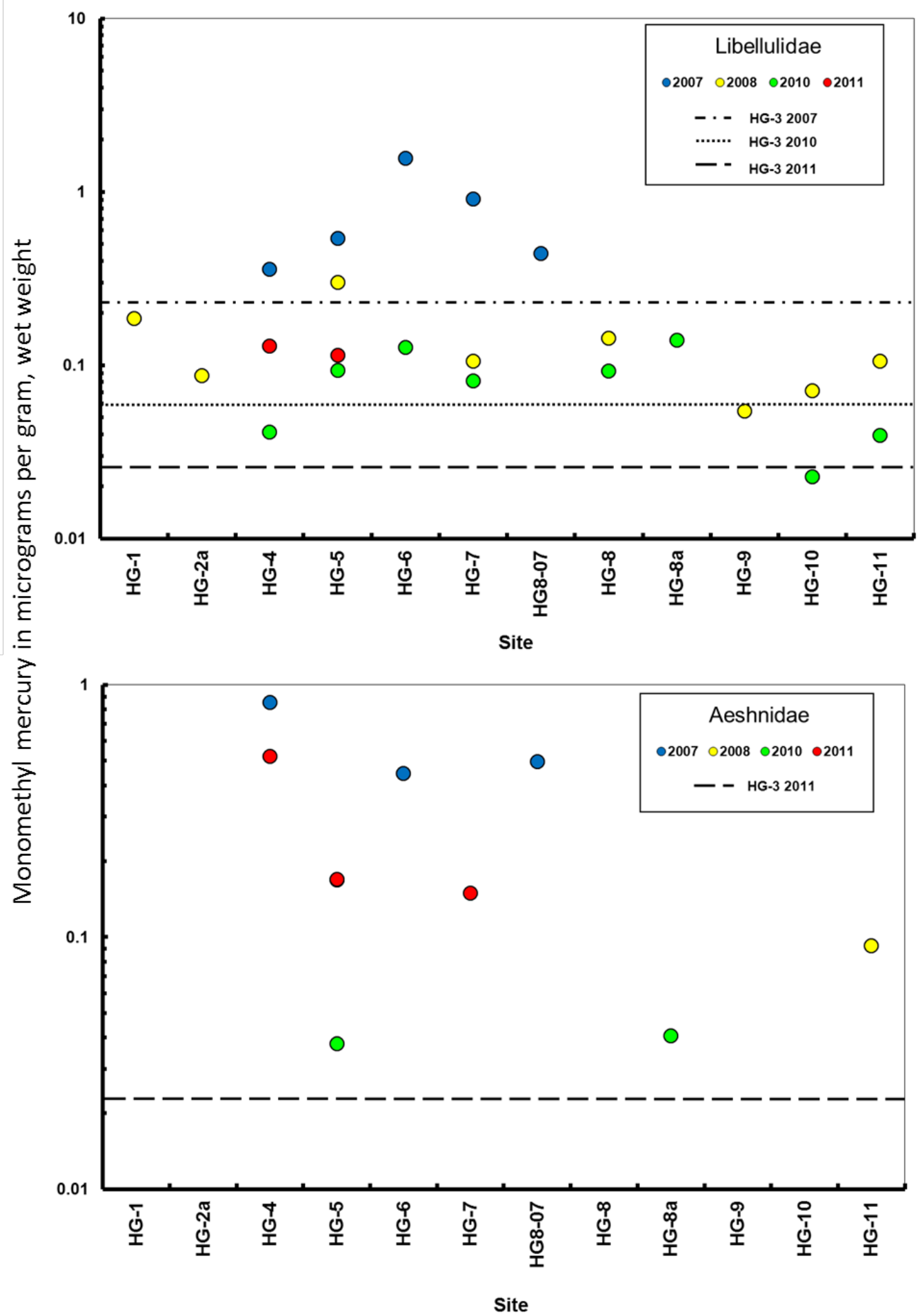

Figure 42. Monomethyl mercury ( $\mathrm{MMeHg}, \mu \mathrm{g} / \mathrm{g}$, wet wt) in individual composite samples of dragonflies (Order Odonata, Families Libellulidae and Aeshnidae) collected from Harley Gulch, Lake County, California, in 2007, 2008, 2010, and 2011. 

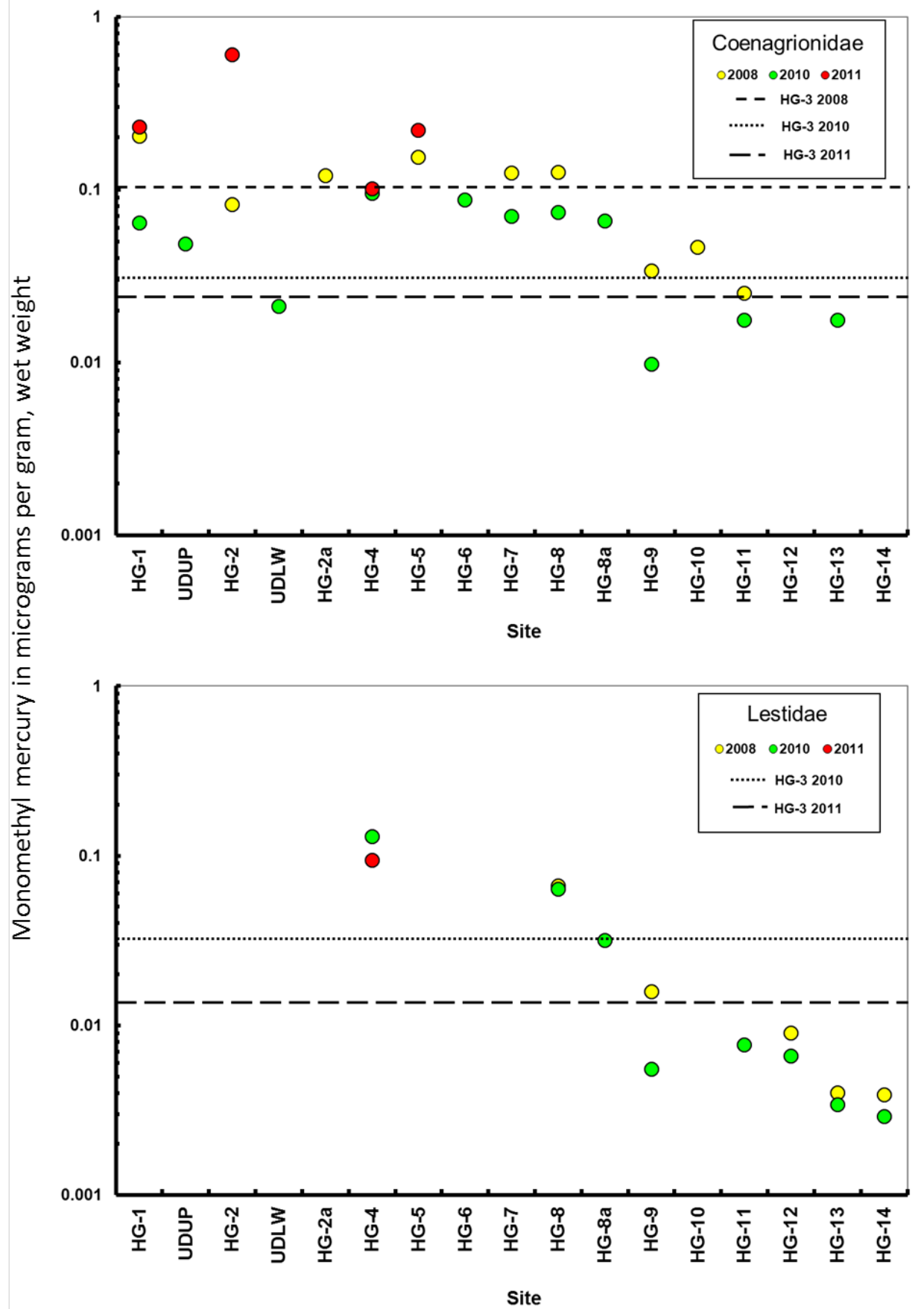

Figure 43. Monomethyl mercury (MMeHg, $\mu \mathrm{g} / \mathrm{g}$, wet $\mathrm{wt}$ ) in individual composite samples of damselflies (Order Odonata, Families Coenagrionidae and Lestidae) collected from Harley Gulch, Lake County, California, in 2008, 2010, and 2011. 


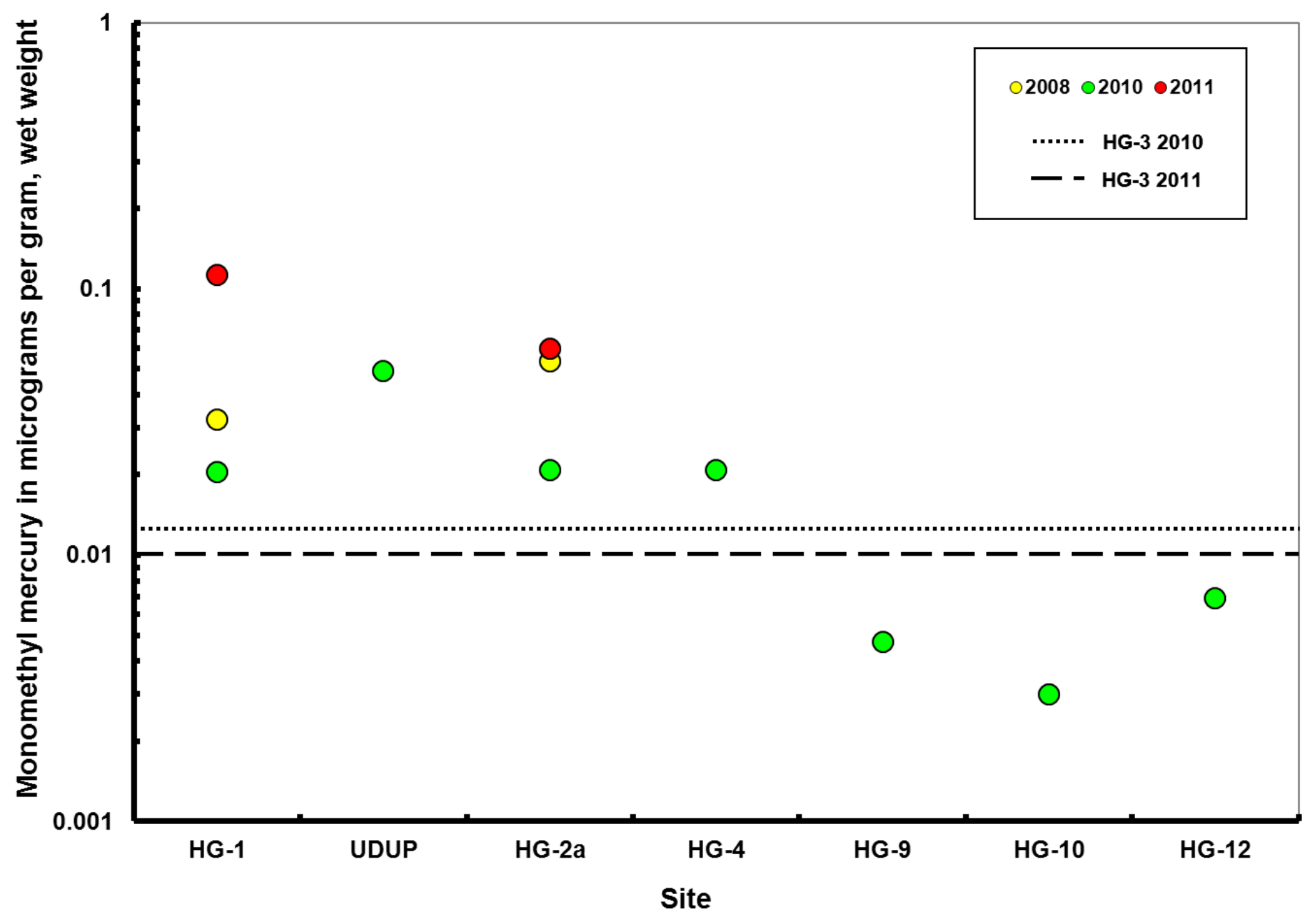

Figure 44. Monomethylmercury (MMeHg, $\mu \mathrm{g} / \mathrm{g}$, wet wt) in individual composite samples of larval water scavenger beetles (Order Coleoptera, Family Hydrophilidae) collected from Harley Gulch, Lake County, California, in 2008, 2010, and 2011. 

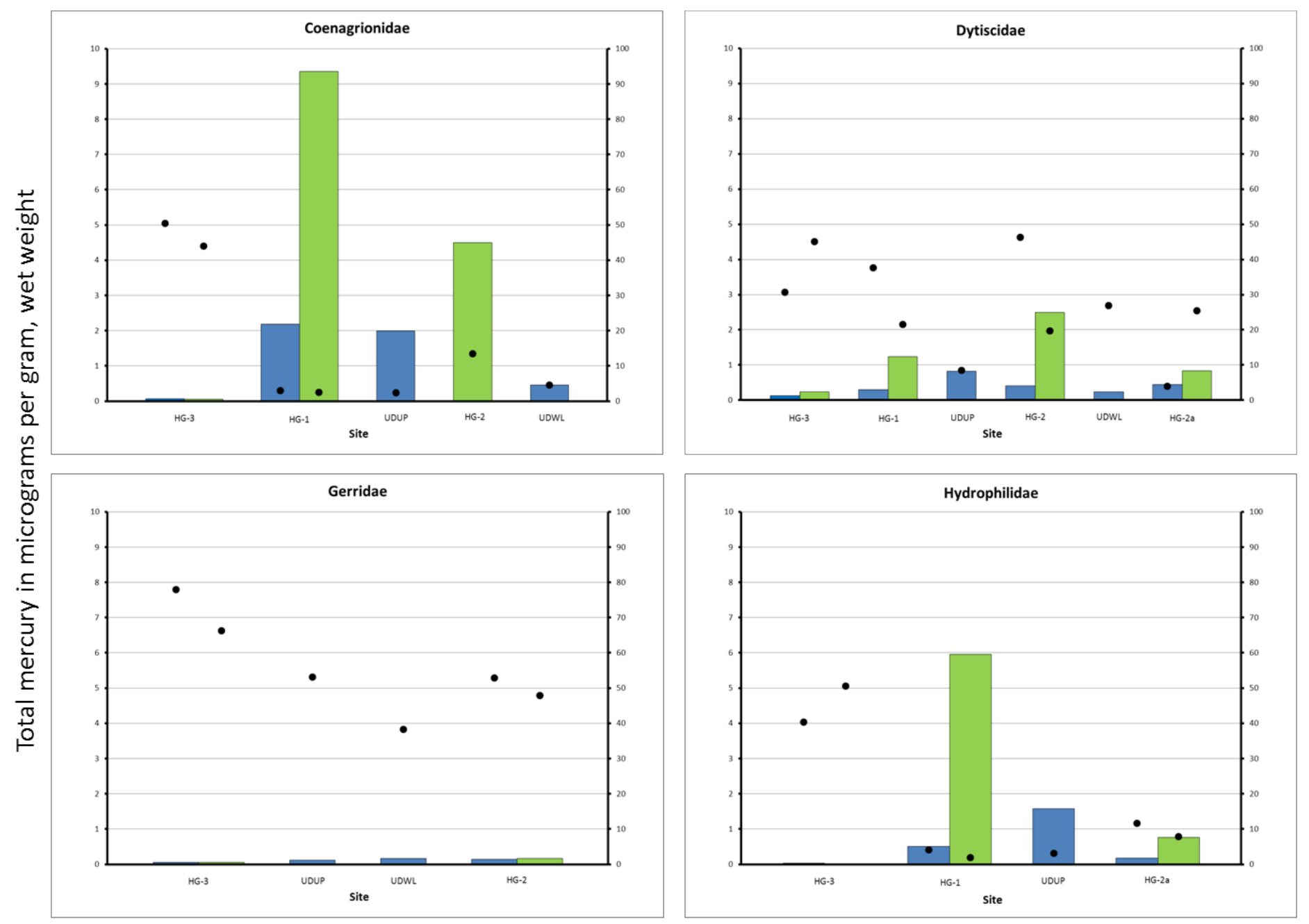

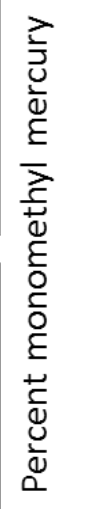

Figure 45. Total mercury $\left(\mathrm{Hg}_{\mathrm{T}}, \mu \mathrm{g} / \mathrm{g}\right.$, wet wt) concentrations and percent monomethyl mercury (MMeHg) (black dots) in individual composite samples of invertebrates (larval Coenagrionidae, adult Dytiscidae, larval Hydrophilidae, and adult Gerridae) collected from a reference site (HG3) and sites in the Harley Gulch wetlands, Lake County, California, in 2010 (blue) and 2011 (green). 


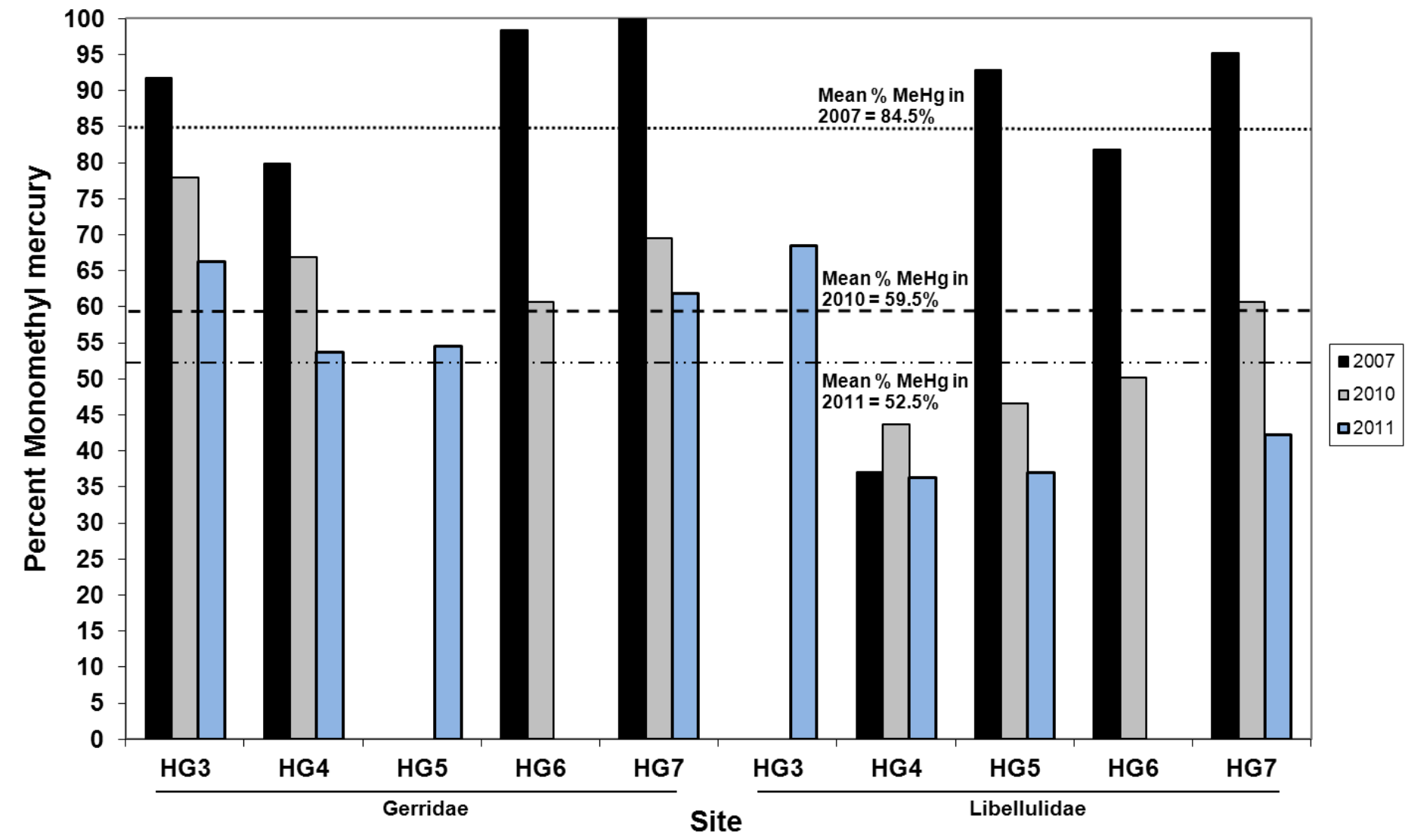

Figure 46. Comparison of percent monomethyl mercury in individual composite samples of water striders (Gerridae) and dragonflies (Libellulidae) collected from four sites in the Harley Gulch, Lake County, California, during 2007 (black), 2010 (gray), and 2011 (blue). 


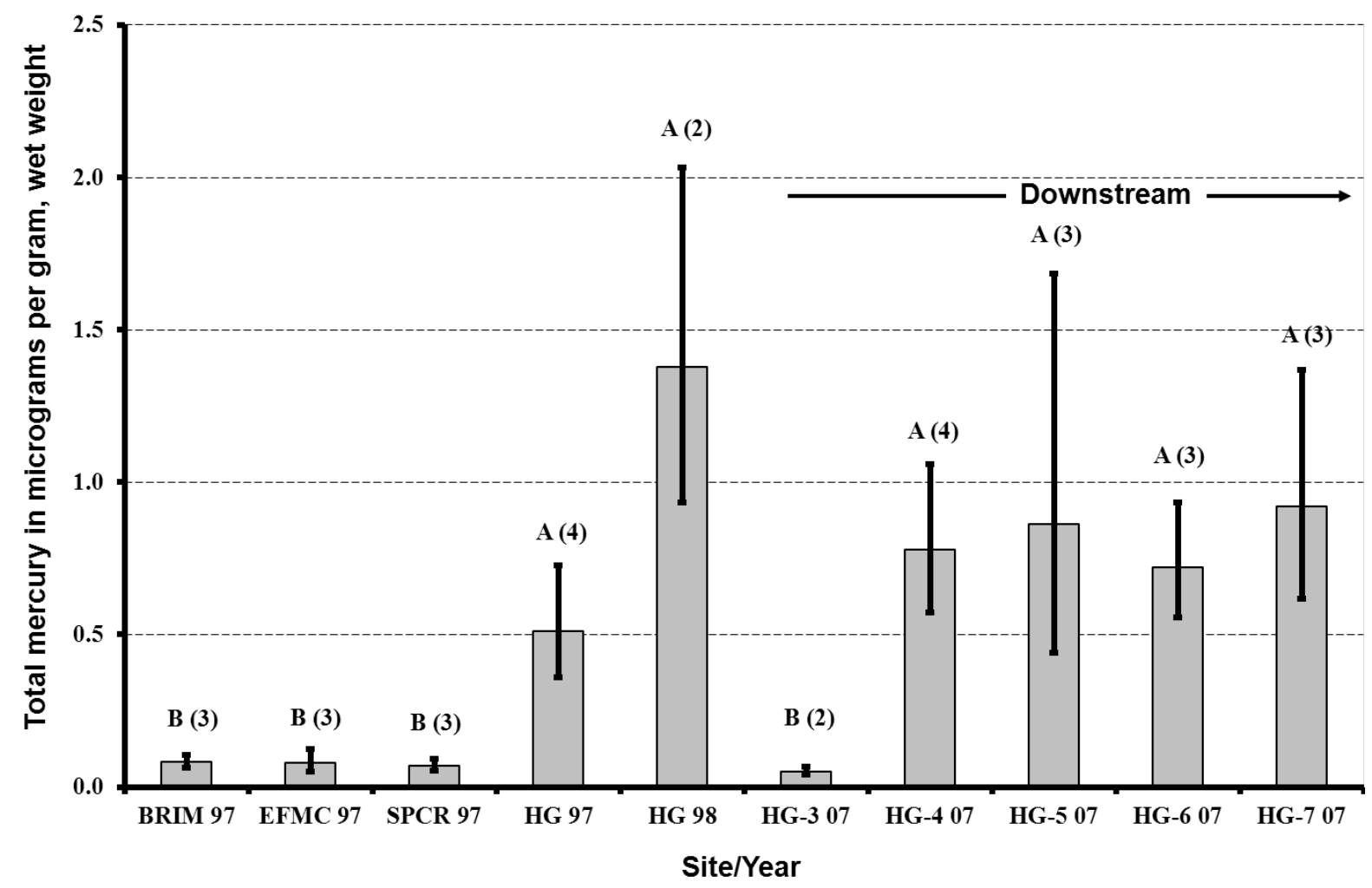

Figure 47. Geometric mean total $\mathrm{Hg}\left(\mathrm{Hg}_{\mathrm{T}}, \mu \mathrm{g} / \mathrm{g}\right.$, wet wt), with 95 percent confidence limits and sample sizes (n), in whole bodies of foothill yellowlegged frogs (FYLF) collected from East Fork Harley Gulch $(\mathrm{H} 3)$ and four sites $(\mathrm{H} 4-7)$ downstream of the confluence of East and West Forks Harley Gulch in May 2007 (table 3), from three reference sites during April-May 1997 (SPCR, Spanish Creek; EFMC, East Fork Middle Creek; BRIM, Bear Creek at Brim Road) (fig. 19), and from Harley Gulch in 1997-1998 (table 11). Harley Gulch included one FYLF from Turkey Run upstream of the West Fork of Harley Gulch in 1997 and one FYLF from the Abbott Mine Drain in 1998 (fig. 1). Means not sharing a common letter were different $(P<0.05)$ by Tukey pairwise multiple-comparison procedure. 


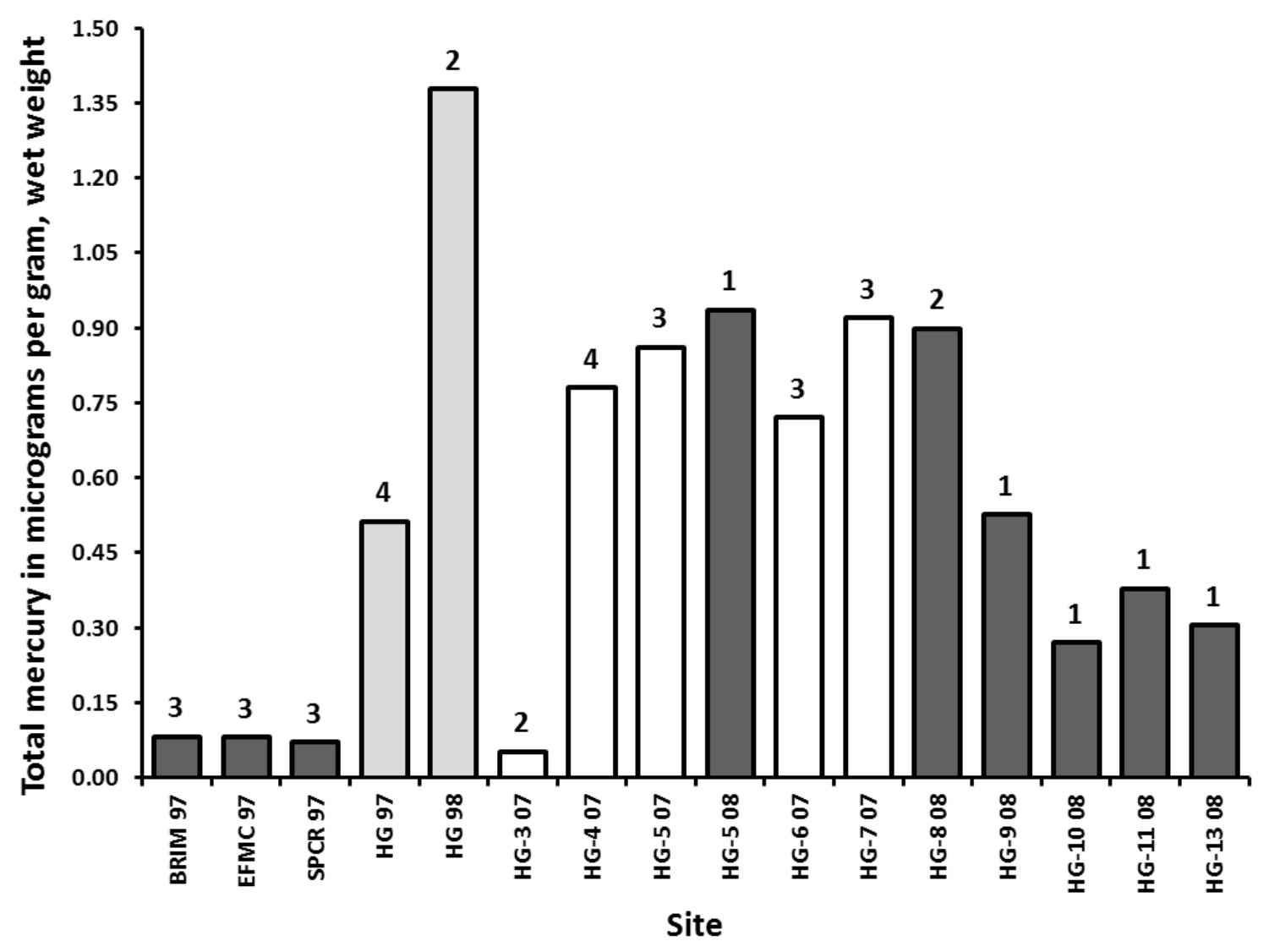

Figure 48. Total mercury $\left(\mathrm{Hg}_{\mathrm{T}}\right)$ concentrations $(\mu \mathrm{g} / \mathrm{g}$, wet wt) in samples of foothill yellow-legged frogs collected from Harley Gulch, Lake County, California, in March-April 1997, March 1998, May 2007, and June 2008. Geometric means are presented for sites where $n>1$. Reference sites (SPCR, Spanish Creek; EFMC, East Fork Middle Creek; BRIM, Bear Creek at Brim Road) were sampled in April-May 1997 (fig. 19). Because only monomethyl mercury (MMeHg) was measured in frogs in 2008, $\mathrm{Hg}_{\mathrm{T}}$ was estimated for these frogs based on 50 percent MMeHg found in frogs analyzed for both MMeHg and HGiin 2007. 


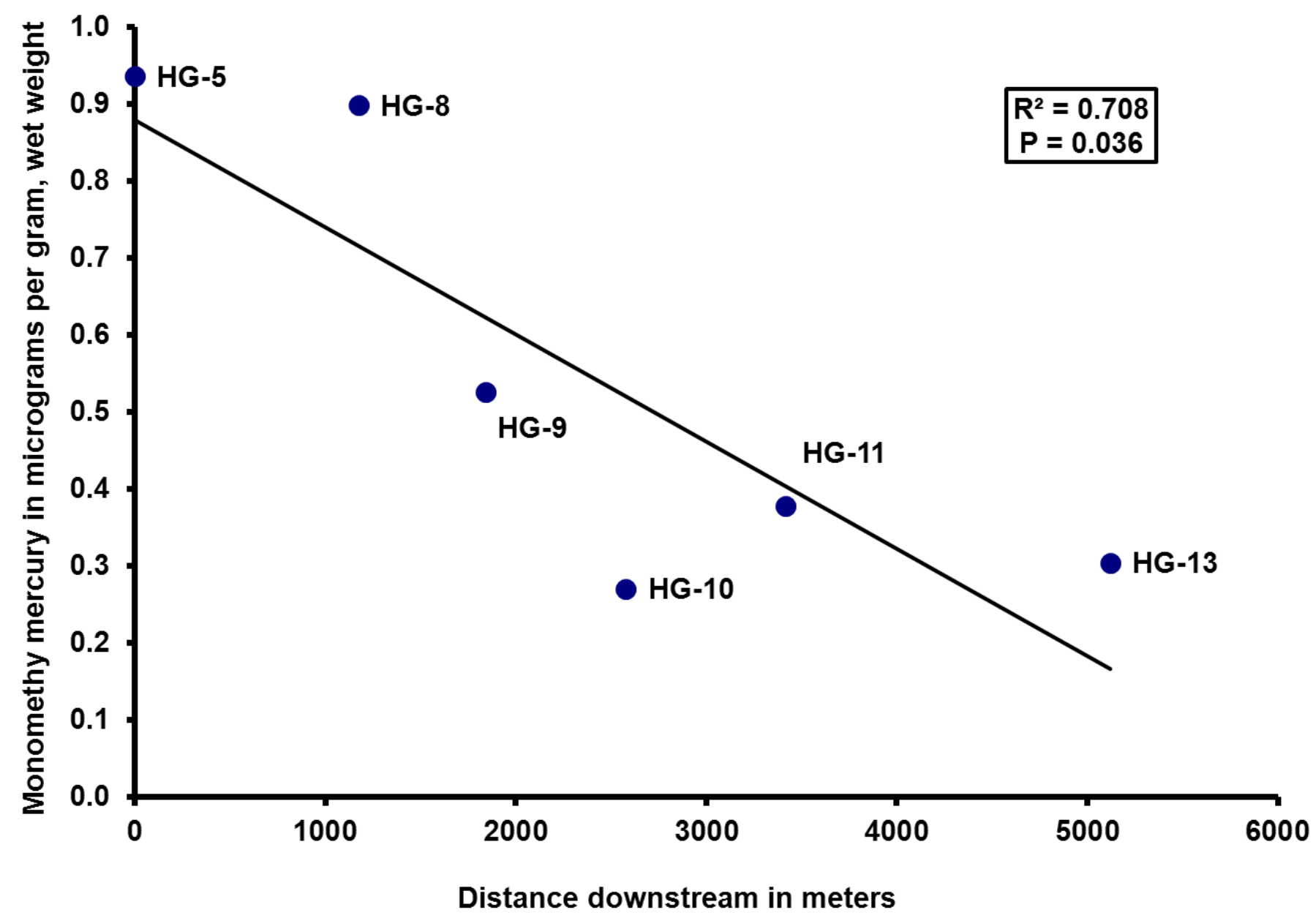

Figure 49. Monomethyl mercury (MMeHg) concentrations ( $\mu \mathrm{g} / \mathrm{g}$, wet wt) in foothill yellow-legged frogs collected from Harley Gulch, Lake County, California, in June 2008. $\mathrm{N}=2$ for HG8; for all other sites, $\mathrm{N}=1$. 


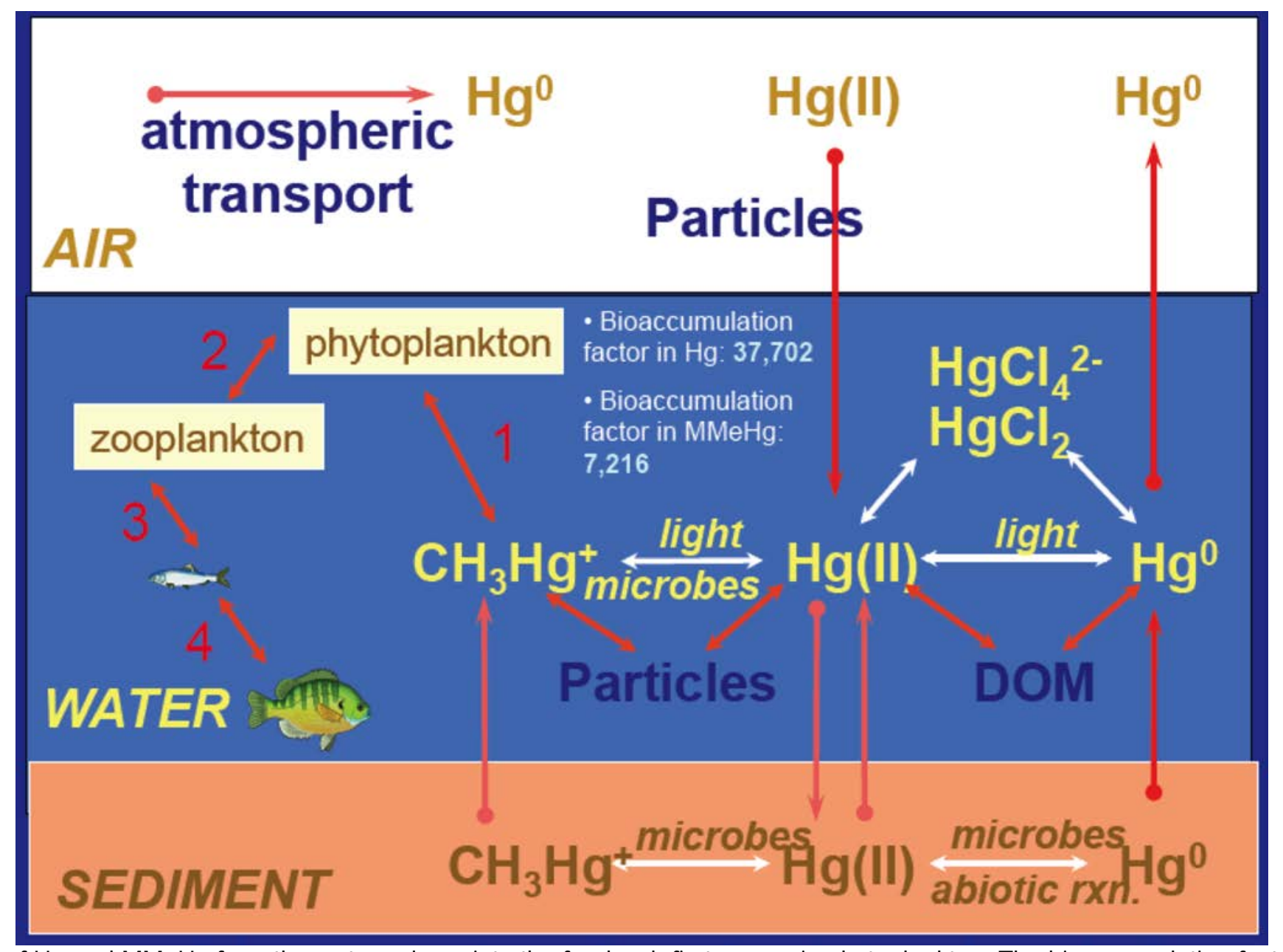

Figure 50. Transfer of $\mathrm{Hg}$ and $\mathrm{MMeHg}$ from the water column into the food web first occurs in phytoplankton. The bioaccumulation factor for both $\mathrm{Hg}$ and $\mathrm{MMeHg}$ is the highest during this transfer, but is still significant in the Hg trophic transfer between phytoplankton and zooplankton (step 2) and upward in the food web, such that fish can have very high $\mathrm{Hg}$ and $\mathrm{MMeHg}$ concentrations. 


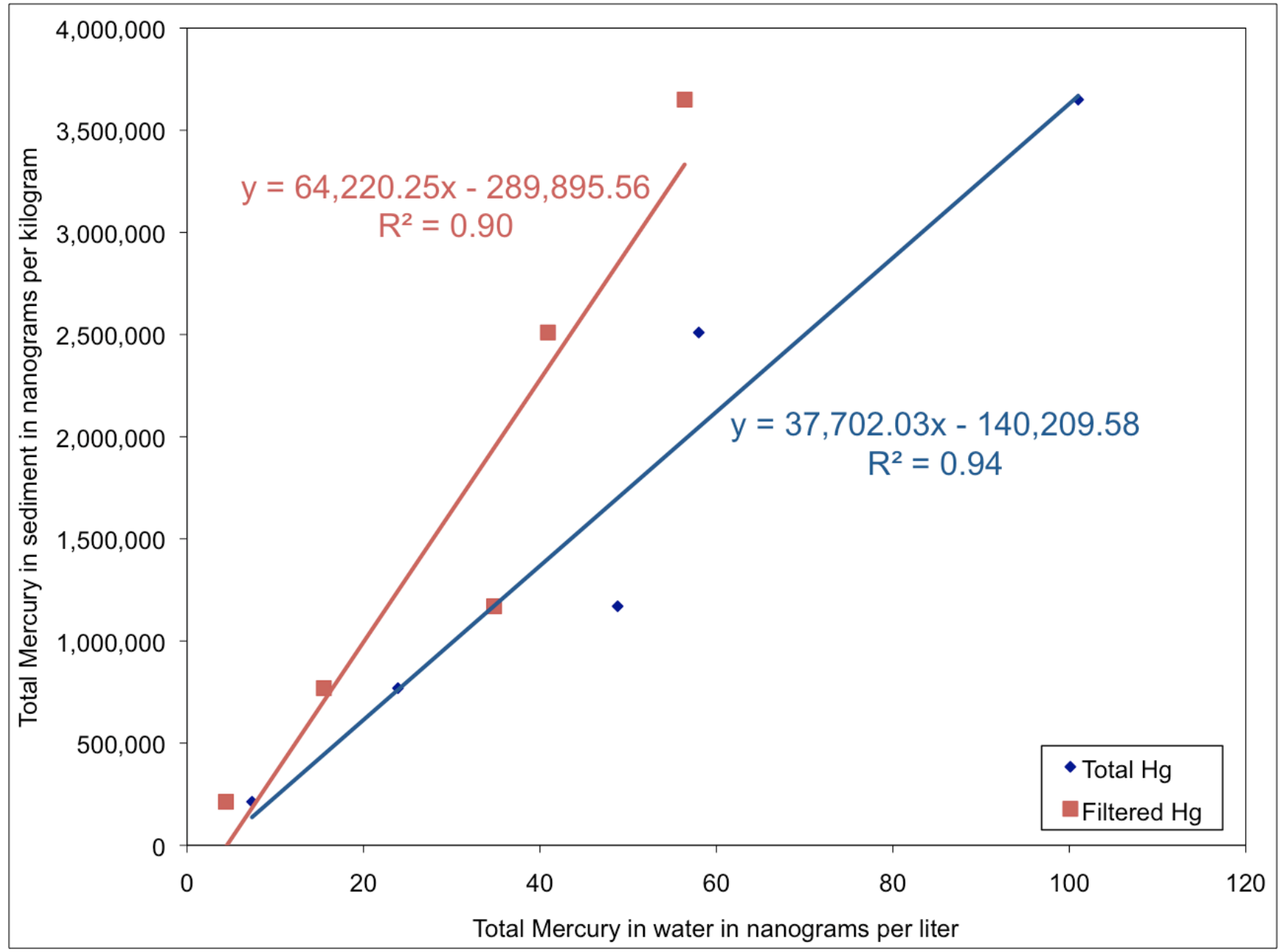

Figure 51. The bioaccumulation factor between phytoplankton in the biogenic sediment in Harley Gulch, Lake County, California, in total $\mathrm{Hg}\left(\mathrm{Hg}_{\mathrm{T}}\right)$ (blue) and filtered $\mathrm{Hg}\left(\mathrm{Hg}_{F}\right)$ (red) in water is very high; 37,700 in $\mathrm{Hg}_{\top}$ and 64,200 in $\mathrm{Hg}_{F}$. The linear relationship demonstrates the $\mathrm{Hg}$ concentration in the biogenic sediment is a function of the $\mathrm{Hg}$ concentration in water. 
Groundwater with elevated $\mathrm{Hg}(\mathrm{II})_{(\mathrm{aq})}, \mathrm{Fe}(\mathrm{III}), \mathrm{SO}_{4}{ }^{2-}, \mathrm{Ba}^{2+}, \mathrm{WO}_{4}{ }^{2-}$

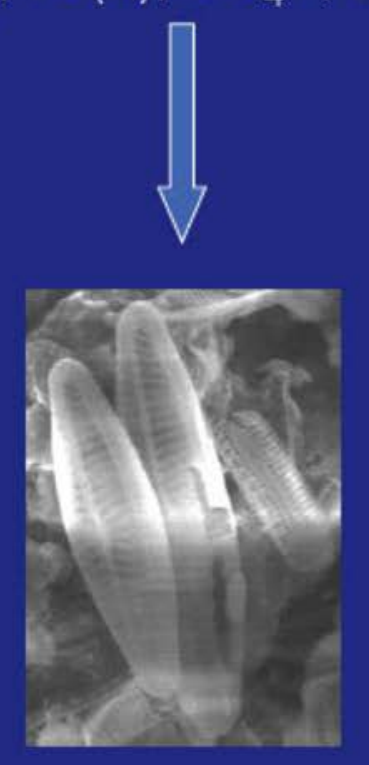

Bioaccumulation of $\mathrm{Hg}, \mathrm{MMeHg}$ Up to $3.7 \times 10^{4}$

\section{Release of Hg from diatoms: reaction with HS-}
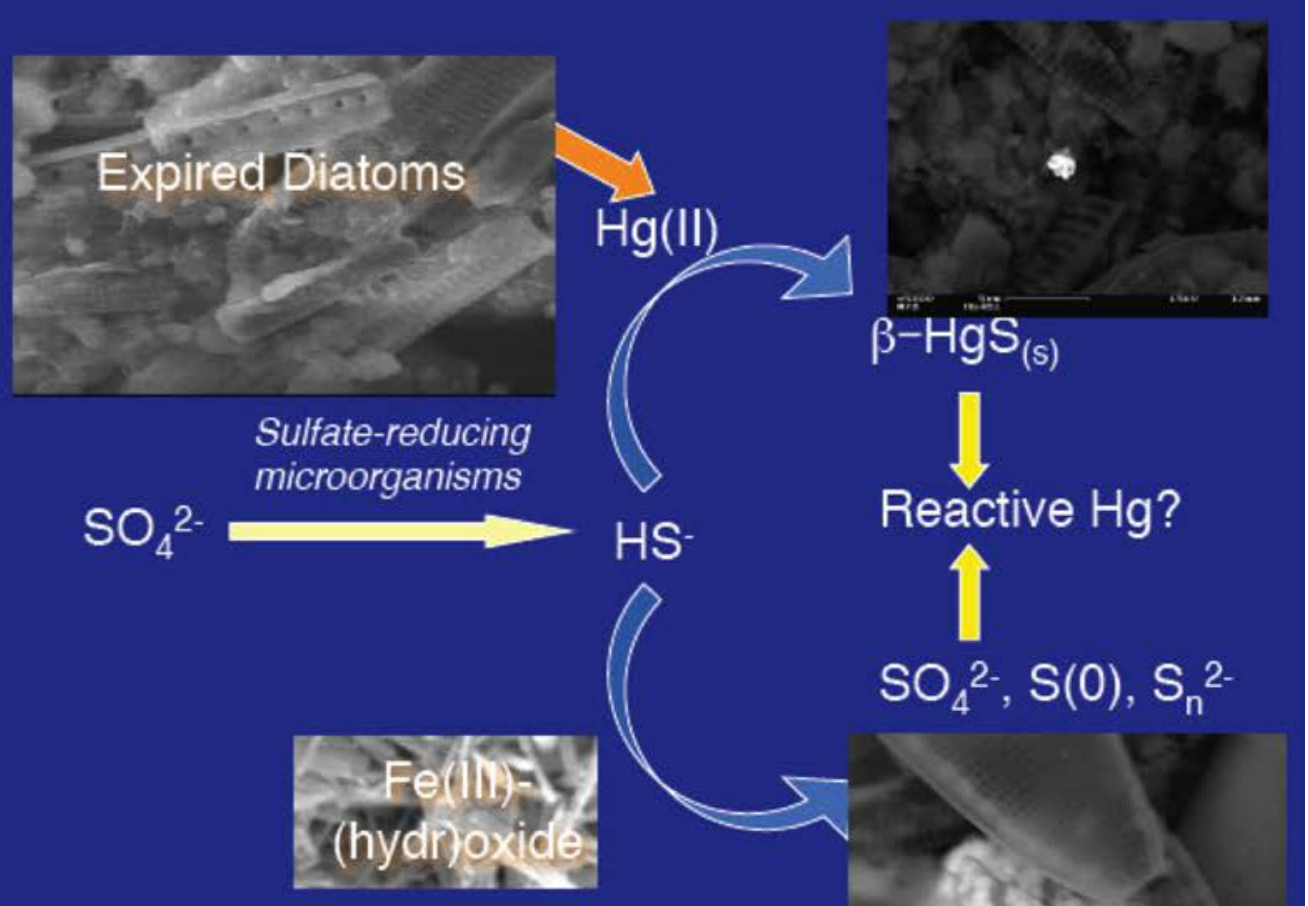

Figure 52. Model for bioaccumulation of $\mathrm{Hg}$ and $\mathrm{MMeHg}$ in diatoms from the water column and subsequent release of $\mathrm{Hg}$ and $\mathrm{MMeHg}$ from the expired diatom that reacts with sulfide to form $\mathrm{HgS}$ and precipitation FeS from reaction of $\mathrm{Fe}$ in the pore fluids with sulfide. 